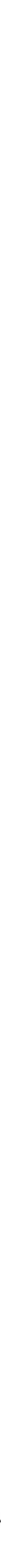




\section{PRAKTIK LITERASI MAHASISWA UNIVERSITAS ISLAM NEGERI: \\ TANTANGAN DAN PELUANG LITERASI DI ERA DIGITAL}

Agus Iswanto, dkk.

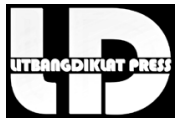

LITBANGDIKLAT PRESS 2019 
PRAKTIK LITERASI MAHASISWA UNIVERSITAS ISLAM NEGERI:

TANTANGAN DAN PELUANG LITERASI DI ERA DIGITAL

Hak cipta dilindungi Undang-undang

All Rights Reserved

\section{Penulis:}

Agus Iswanto

Moch. Lukluil Maknun

Mustolehudin

Umi Masfiah

Subkhan Ridlo

Roch. Aris Hidayat

Desain Cover dan Layout:

A. Basith

Diterbitkan oleh:

LITBANGDIKLAT PRESS

JL. M.H. Thamrin No. 6 Lantai 17 Jakarta Pusat

Telepon: 021-3920688

Fax: 021-3920688

Website: balitbangdiklat.kemenag.go.id

Anggota IKAPI No. 545/Anggota Luar Biasa/DKI/2017

Cetakan:

Pertama Oktober, 2019

ISBN: 978-602-51270-8-3 


\section{PRAKATA}

Puji syukur kepada Allah SWT atas terbitnya buku ini. Buku ini dapat terbit karena keterlibatan banyak pihak, mulai dari sebelum terbentuk buku hingga hadir ke hadapan para pembaca semua. Buku ini semula adalah sebuah laporan hasil penelitian kompetitif yang didanai oleh anggaran Balai Litbang Agama Semarang. Oleh karena itu, penulis perlu menghaturkan ucapan terima kasih kepada semua pihak yang terlibat secara langsung maupun tidak dalam proses penerbitan buku ini.

Pertama tentu kepada Kepala Balai Litbang Agama Semarang saat penelitian ini dilakukan, yakni Prof. Dr. Koeswinarno, M.Hum. Melalui arahannya, hasil penelitian ini diajukan untuk diterbitkan melalui Litbangdiklat Press (LD Press). Sebagai sebuah hasil penelitian kompetitif yang diselenggarakan pada masa kepemimpinannya, segala proses penelitian ini, mulai dari penulisan proposal, review, dan revisi telah dilewati. Hal tersebut tiada lain karena hasil kerja para tim reviewer di Balai Litbang Agama Semarang yang tergabung dalam Tim Penjamin Mutu Internal Peneliti (TPMIP). Oleh karena itu, penulis mengucapkan terima kasih kepada para reviewer yang bersedia membaca, mengoreksi, 
dan mengomentari proposal, desain operasional penelitian hingga laporan penelitian yang menjadi dasar buku ini. Penulis juga mengucapkan terima kasih kepada para reviewer di Litbangdiklat Press.

Banyak pihak yang terlibat saat penelitian ini dilakukan, para mahasiswa, dosen, para pustakawan maupun pejabat di kampus-kampus yang menjadi lokasi penelitian, yakni UIN Sunan Kalijaga Yogyakarta, UIN Walisongo Semarang, UIN Sunan Ampel Surabaya, UIN Maulana Malik Ibrahim Malang, UIN Mataram, UIN Banjarmasin. Atas bantuan mereka semua, penulis ucapkan terima kasih. Tanpa bantuan pihak-pihak di lokasi penelitian, mustahil para peneliti mendapatkan data yang penting untuk membuat dan menyusun argumen-argumen dan kesimpulan dalam laporan hasil penelitian. Semoga informasi yang diberikan dapat membantu memperbaiki kualitas literasi, serta memperkaya wacana kajian praktik literasi di Indonesia yang masih jarang ditulis dalam kajian akademis.

Meskipun banyak pihak yang terlibat dalam proses penelitian dan penerbitan buku ini, semua isi yang ada dalam buku ini menjadi tanggung jawab para penulis. Akhirnya kepada pembaca, penulis mengharapkan saran untuk kesempurnaan buku ini di masa yang akan datang.

Semarang, 18 Juli 2019

Penulis Utama

Agus Iswanto 


\section{DAFTAR ISI}

Prakata ................................................................ ii

Daftar Isi .......................................................... V

BAB I. Pendahuluan …..................................... 1

Problem Literasi Indonesia .................................. 1

Praktik Literasi Mahasiswa Universitas Islam Negeri (UIN) 5

Penelitian tentang Praktik Literasi ….................... 8

Memahami Praktik Literasi: Konsep-konsep teoritis .. 15

Meneliti dan Menyajikan Praktik Literasi Mahasiswa UIN:

Catatan Metode $\quad$........................................................ 33

BAB II. "Ruang dan Waktu": Latar Praktik Literasi 39

Latar Ruang: Kampus sebagai Sponsor Praktik Literasi 40

UIN dan Potensi Pengembangan Multiliterasi ........... 61

Latar Waktu: Generasi Milenial ............................. 67

BAB III. Infrastruktur Literasi Mahasiswa: Kondisi Perpustakaan, Pemanfaatan, dan Tantangan Media Online .................................................................... 79

Kondisi Perpustakaan................................................. 80 
Pemanfaatan Perpustakaan: Sebatas Menjadi Motivasi Ekstrinisk Literasi

Akses Ilmu Pengetahuan Melalui Media Online Berbasis Universitas

BAB IV. Mempraktikkan Literasi

Sikap terhadap Membaca dan Menulis …………..... 123

Perilaku Membaca dan Menulis

1. Tujuan membaca: "Membaca untuk belajar dan membaca untuk kesenangan"

2. Membaca Genre fiksi lebih disukai mahasiswa .. 132

3. Membaca Literatur Non Fiksi ……….............. 135

4. Perilaku Literasi Menulis ................................. 137

5. Perilaku Tidak Literat: Perilaku Plagiat atau "CopyPaste"

Komunitas Literasi Mahasiswa: Membaca Artefak Motivasi Intrinsik Literasi

1. Lembaga Pers Mahasiswa _.................................. 147

2. Komunitas Diskusi dan Kepenulisan ................. 163

3. Kelompok Penulis Mandiri …………………..... 169

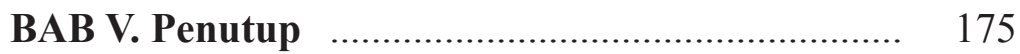

Daftar Pustaka ........................................................... 185

Biodata Penulis $\quad$........................................................ 201

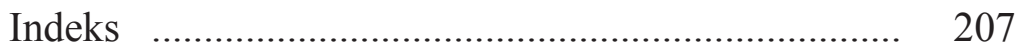




\section{BAB I \\ PENDAHULUAN}

\section{Problem Literasi Indonesia}

Literasi menjadi fokus pembangunan berbagai negara di dunia (UNESCO Institute for Life Long Learning, 2017: 9). Keberhasilan pendidikan di era sekarang ini berada dalam pengaruh literasi (Miller dan McKenna, 2016: 2; Alhumami, 2018). Oleh karena itu UNESCO, melalui Forum Ekonomi Dunia (World Economic Forum/WEF) pada tahun 2015 menyebutkan bahwa salah satu kompetensi abad 21 yang harus dimiliki seseorang adalah kompetensi literasi.

Literasi pada abad ke-21 sesungguhnya bukan hanya sekadar "melek huruf," tetapi lebih dari itu. Alvin Toffler pada tahun 1970, sebagaimana dikutip oleh Kasali (2018: 226) sudah "meramalkan" bahwa "buta aksara" atau "buta huruf" bukan lagi berarti tidak bisa baca-tulis, melainkan tidak bisa belajar, enggan belajar, dan enggan belajar kembali. Karena itu, wajar jika dalam beberapa kasus, ditemukan banyak guru, siswa, mahasiswa bahkan dosen sekalipun belum mampu memahami apa yang sedang mereka baca, tulis atau teliti. Literasi kini lebih dipahami sebagai sebuah kemampuan memahami dan mengkomunikasikan. 
Beberapa studi menunjukkan manfaat atau dampak positif yang didapat dari kualitas literasi. Manfaat-manfaat tersebut ada yang bersifat manusiawi-individual (human benefits), politik, budaya, sosial maupun ekonomi. Manfaat yang bersifat manusiawi-individual dari literasi adalah seperti peningkatan harkat diri, memberdayakan individu dalam kehidupan dan meningkatkan refleksi diri. Manfaat literasi di bidang politik antara lain meningkatkan partisipasi politik, meningkatkan kualitas demokrasi, meningkatkan kesadaran kesetaraan etnis, dan dapat membantu perbaikan situasi pasca konflik. Literasi juga bermanfaat di bidang budaya, yakni dapat menjaga kelestarian keragaman budaya serta kritis dan evaluatif dalam menghadapi perubahan budaya. Manfaat sosial dari literasi dapat meningkatkan kesadaran kesetaraan hak pendidikan, kesehatan, gender, dan perilaku reproduksi. Literasi juga memiliki manfaat di bidang ekonomi, yaitu dapat meningatkan pertumbuhan ekonomi (UNESCO, 2005: 137-145).

Namun, dunia pendidikan Indonesia dalam kurun satu dekade ini dihentakkan dengan munculnya beberapa hasil survei yang menunjukkan rendahnya kemampuan literasi anak-anak Indonesia. Tes PISA (Programme for Student Assessment) tahun 2015 tidak menunjukkan kenaikan yang signifikan dalam kompetensi literasi orang Indonesia, meskipun pada kompetensi sains dan matematika ada peningkatan yang signifikan (https://www.kemdikbud.go.id/ main/blog/2016/). Sementara itu, survei yang dilakukan oleh Central Connecticut State University (CCSU) tahun 2016 tentang perilaku literat, menunjukkan bahwa Indonesia masih berada di urutan ke-60 dari 61 negara yang mengikuti survei perilaku literasi ini. (https://webcapp.ccsu. 
edu/?news $=1767 \&$ data). Begitu juga, hasil tes Progress in International Reading Literacy Study (PIRLS) tahun 2011 menempatkan Indonesia pada urutan ke 40 dari 42 negara yang mengikuti survei (Thompson, dkk., 2012: 8).

Dengan proporsi jumlah penduduk 'melek huruf' di atas $90 \%$, seharusnya masyarakat Indonesia dapat berbangga diri. Menurut data Kementerian Pendidikan dan Kebudayaan, Pemerintah Indonesia mengklaim telah mengentaskan sekitar 150.000 penyandang tuna aksara di tahun 2014. Angka ini hanya menyisakan 3,76\% dari jumlah penduduk atau sekitar 6 juta orang (Dewayani, 2017: 9-11). Namun 'melek huruf' tidak membuat anak-anak Indonesia memiliki kualitas literasi yang baik.

Jika merunut pada Kompetensi Dasar Bahasa Indonesia dalam Kurikulum 2013, maka pada jenjang Sekolah dasar (SD) saja seharusnya seorang siswa sudah mampu memahami makna teks yang ditulis dalam beragam genre, meringkasnya, menelaah, merevisinya dan mengungkapkan pendapatnya secara lisan dan tulisan. Namun, faktanya kemampuan siswa Indonesia yang berusia 15 tahun untuk memahami bacaan masih tertinggal dalam sejumlah survei internasional (Dewayani, 2017: 10).

Hal ini kemudian mendorong literasi menjadi isu nasional (Antoro, 2017: 5). Kata literasi muncul dalam Arah Kebijakan Umum Pembangunan Nasional 2015-2019 (Rencana Pembangunan Jangka Menengah Nasional 20152019), khususnya pada arah kebijakan 'meningkatkan kualitas sumber daya manusia, yakni meningkatkan kompetensi siswa di bidang matemika, sains dan literasi.' Dalam arah kebijakan dan strategi pembangunan pendidikan, di antara arah kebijakannya adalah memperkuat kurikulum dan 
pelaksanaannya melalui peningkatan kualitas pembelajaran literasi, matematika, dan sains sebagai kemampuan dasar yang dibutuhkan dalam kehidupan sehari-sehari. Literasi menjadi kata, istilah, dan isu yang aktual diperbincangkan dan diprogramkan baik oleh pemerintah maupun masyarakat.

Untuk mewujudkan pendidikan yang berkualitas sekarang ini, hal yang terbaik adalah melalui peningkatan kualitas literasi. Hal ini tidak akan tercapai dengan baik tanpa pengetahuan yang cukup tentang praktik literasi yang sudah dilakukan masyarakat dan lembaga pendidikan. Untuk mendapatkan pengetahuan tersebut, dibutuhkan penelitian tentang praktik literasi sebagai pijakan awal bagi pengembangan dan peningkatan kualitas literasi di lembaga pendidikan. Pengetahuan tentang praktik literasi tidak hanya tentang angka-angka prestasi literasi, tetapi juga tentang pola praktik literasi yang ada di tengah masyarakat dan lembaga pendidikan.

Kajian-kajian tentang praktik literasi di Indonesia masih dilakukan secara parsial yang terbatas pada konteks yang sempit - seperti hasil penelitian Gustini, Rohaniawati dan Imani (2016) - sehingga belum memiliki informasi yang signifikan jika diteruskan dalam pembuatan kebijakan. Apalagi yang sering kali mendapatkan perhatian adalah literasi di tingkat sekolah dasar dan menengah, itu pun lebih banyak mengukur kemampuan membaca dan menulis secara kognitif semata dengan ukuran-ukuran yang sudah digunakan oleh lembaga-lembaga riset internasional. Padahal, menurut Dewayani dan Retnaningdyah (2017: 8-10), sebaiknya kajian literasi menggali sebanyak mungkin praktik literasi dan kondisi-kondisi infrastruktur literasi yang ada di masyarakat, termasuk di lembaga pendidikan yang berbasis agama. 
Apalagi, di tengah perkembangan revolusi digital sekarang, tentu praktik literasi pun mengalami perubahan.

\section{Praktik Literasi Mahasiswa UIN}

Tidak banyak ditemukan penelitian tentang praktik literasi di lembaga-lembaga pendidikan berbasis agama, seperti Perguruan Tinggi Agama Islam Negeri (PTAIN). Pengetahuan tentang praktik di lembaga-lembaga pendidikan tinggi berbasis agama atau Perguruan Tinggi Keagamaan Islam (PTKIN) di Indonesia terbatas, untuk tidak mengatakan kurang. Bagi Kementerian Agama yang membina Perguruan Tinggi Agama Islam, termasuk di dalam Universitas Islam Negeri (UIN), informasi tentang praktik literasi mahasiswa di lembaga tersebut penting sebagai data untuk meningkatkan kualitas pendidikan.

Penelitian tentang praktik literasi di perguruan tinggi penting dilakukan, sebab perguruan tinggi dengan mahasiswa dan dosen di dalamnya adalah subyek yang memproduksi ilmu pengetahuan. Peran perguruan tinggi sebagai produsen ilmu pengetahuan menjadi lebih kompleks ketika dikaitkan dengan perkembangan cyber space atau teknologi digital seperti sekarang ini. Perguruan tinggi, termasuk perguruan tinggi agama, dihadapkan pada permasalahan literasi di tengah revolusi digital dewasa ini. Seperti apa praktik literasi mahasiswa di tengah abad literasi dan teknologi digital yang sedang dihadapi ini? Bagaimana infrastruktur yang mendukung praktik literasi di era milenial dan revolusi digital dalam teknologi informasi.

Buku ini berupaya menyajikan pola praktik literasi mahasiswa Universitas Islam Negeri (UIN) yang menjadi wilayah kerja Balai Litbang Agama Semarang, yakni 
Yogyakarta, Jawa Tengah (Semarang) Jawa Timur (Surabaya dan Malang), Nusa Tenggara Barat (Mataram) dan Kalimantan Selatan (Banjarmasin). Selain menggali pola praktik literasi dalam konteks perkembangan abad milenial, buku ini mendiskusikan kondisi infrastruktur yang mendukung praktik literasi mahasiswa serta pemanfaatan infrastruktur tersebut untuk mengembangkan praktik literasi mahasiswa. Sebab, kesedian infrastruktur literasi dan akses atau pemanfaatan infrastruktur literasi menjadi salah satu faktor penting berjalannya literasi.

Buku ini membatasi praktik literasi pada praktik membaca dan menulis terhadap obyek bacaan dan tulisan yang beragam. Hal ini karena meskipun sekarang telah berkembang konsep 'multiliterasi' (Abidin, Mulyati dan Yunansah, 2017: 7; Dewayani, 2017: 10), namun tetap saja dasar dari multiliterasi adalah kemampuan membaca dan menulis. Adapun pembatasan pada PTKIN yang sudah berstatus universitas, atau yang telah menjadi UIN, lebih dikarenakan pembatasan pada fokus sasaran penelitian agar lebih bisa melihat sumbangan universitas yang berada di bawah pembinaan Kementerian Agama terhadap praktik literasi. Nomenklatur UIN lebih menyarankan adanya multi keilmuan dan multiperspektif yang sesuai dengan perkembangan literasi abad ke-21.

Fokus bahasan buku ini mencakup dua hal. Pertama, kondisi infrastruktur literasi dan pemanfaatannya oleh mahasiswa di UIN di Yogyakarta, Jawa Tengah, Jawa Timur, Nusa Tenggara Barat dan Kalimantan Selatan. Kedua, praktik literasi membaca dan menulis di kalangan mahasiswa UIN di Yogyakarta, Jawa Tengah, Jawa Timur, Nusa Tenggara Barat dan Kalimantan Selatan. 
Kondisi infrastruktur literasi yang dimaksud dalam penelitian ini adalah perpustakaan dan media ilmu pengetahuan berbasis online. Adapun praktik literasi yang dimaksud dalam penelitian ini adalah literasi membaca dan menulis terhadap beragam genre dan media, yang terkadang tidak selalu berhubungan dengan kondisi infrastruktur yang tersedia oleh karena keragaman minat literasi mahasiswa.

Buku ini diharapkan dapat bermanfaat baik secara teoritis maupun praktis. Secara teoritis, buku ini dapat memberikan pengetahuan tentang praktik literasi Indonesia, sehingga dapat diketahui bahwa praktik literasi juga berlangsung di Indonesia dengan segala kekurangan dan kelebihannya. Penelitian ini juga dapat menjadi salah satu cara menandingi wacana tentang literasi di Indonesia yang terlalu "bias Barat," sebab selalu dilihat dalam parameter praktik literasi Barat. Padahal menurut beberapa eksponen kajian literasi baru, kecakapan literasi tidak hanya diukur dengan capaian pembelajaran formal dan mekanistik.

Secara praktis, penelitian ini dapat memberikan data mengenai praktik literasi dan kendalanya bagi Kementerian Agama, khususnya pada Direktorat Pendidikan Tinggi Keagamaan Islam (Diktis). Informasi ini dapat digunakan sebagai pijakan untuk meningkatkan kualitas pendidikan di Perguruan Tinggi Agama Islam (PTAI) sebagaimana yang tercantum dalam Rencana Strategis Kementerian Agama 2015-2019. Dengan data praktik literasi ini, Kementerian Agama dapat menentukan kebijakan-kebijakan peningkatan kualitas pendidikan di PTAI yang searah dengan kompetensi literasi yang dibutuhkan di abad 21 di satu sisi, dan disenangi serta sesuai dengan gaya anak muda (mahasiswa) di sisi yang lain. 


\section{Penelitian tentang Praktik Literasi}

Penelitian-penelitian tentang literasi di Indonesia lebih banyak tentang pencapaian-pencapaian atau tingkat-tingkat literasi di berbagai bidang literasi, misalnya tingkat literasi siswa di sekolah tertentu, atau tingkat literasi media di kampus tertentu. Terkadang juga mencoba menguji hubunganhubungan atau pengaruh-pengaruh dengan locus yang sangat spesifik, seperti hubungan tingkat literasi siswa dengan tingkat kelulusan, atau pengaruh tingkat literasi terhadap prestasi belajar siswa di sekolah tertentu. Penelitian-penelitian yang ada belum banyak yang mencoba menggali praktik literasi pada masyarakat Indonesia. Kajian-kajian literasi lebih banyak menggunakan perspektif 'literasi otonom' daripada 'kajian literasi baru' yang kontekstual.

Hal ini sebetulnya dapat dilihat sebagai pengaruh beberapa hasil survei literasi yang dilakukan lembaga penelitian luar negeri. Misalnya adalah survei Institute of Education Sciences - sebuah lembaga riset yang berada di bawah Kementerian Pendidikan Amerika-membuat sebuah program penelitian dengan judul The Progress in International Reading Literacy Study (PIRLS). Penelitian tersebut mengukur kemampuan literasi membaca anak (Thompson, dkk., 2012) dengan melihat tiga aspek, yakni pemahaman terhadap bacaan, tujuan-tujuan membaca dan perilaku dan sikap terhadap bacaan. Namun, yang lebih mengemuka adalah hasil tentang tingkat pemahaman terhadap bacaan di mana Indonesia berada di ranking bawah. Padahal, aspek tujuan dan perilaku membaca bisa digali lebih dalam untuk melihat praktik literasi masyarakat Indonesia.

Penelitian yang dilakukan oleh Central Connecticut State University (CCSU) tahun 2016 tentang perilaku 
literat masyarakat, menunjukkan bahwa Indonesia masih berada di urutan ke-60 dari 61 negara. Penelitian ini selain melihat prestasi membaca masyarakat di negara-negara yang disurveinya, juga melihat ketersediaan sumber dukungan literasi, seperti perpustakaan, sirkulasi penerbitan surat kabar dan majalah, sistem pendidikan serta ketersediaan komputer. Laporan CCSU ini, sebagaimana dikutip oleh Dewayani dan Retnaningdyah (2017: 2), menyebutkan bahwa akses masyarakat terhadap informasi dan produksi pengetahuan memengaruhi kesejahteraan ekonomi suatu negara. Lebih lanjut, laporan ini menyebutkan bahwa sebuah bangsa yang tidak literat cenderung memiliki perilaku yang represif terhadap hak asasi manusia, berpikiran sempit bahkan brutal. Namun tampaknya CCSU belum benar-benar menelusuri praktik literasi masyarakat di negara-negara tersebut, seperti apa teks yang dibaca dan tujuan-tujuan membaca di kalangan masyarakat? Hal yang tampak dari hasil penelitian tersebut lebih pada meranking prestasi membaca masyarakat dan indeks ketersediaan dukungan terhadap prestasi membaca.

Sesungguhnya, kajian literasi mengalami perkembangan, tidak hanya meneliti capaian-capaian prestasi literasi, tetapi juga literasi telah dikaji sebagai sebuah 'alat yang tersituasikan secara budaya, sejarah dan sosial' untuk memperoleh pengetahuan dan keterampilan yang mentransformasikan pikiran dan pengalaman (Rackley, 2010: 3; Barton, Hamilton dan Ivanic, 2000: 1). Secara sederhana, literasi dikaji sebagai sebuah praktik masyarakat dalam situasi tertentu untuk memperoleh pengetahuan dan keterampilan dalam rangka transformasi masyarakat itu sendiri. Literasi selalu punya konteks dan tujuan dalam berbagai masyarakat. Dari sini kemudian muncul istilah 'praktik literasi.' Beberapa 
penelitian yang berangkat dari konsep praktik literasi adalah misalnya Lancaster University dan University of Stirling (2007), Rackley (2010), Retnaningdyah_sebagaimana kemudian ditulis ulang dalam bahasa Indonesia bersamasama Dewayani (2017)—, dan Dewayani (2011). Ketiganya menerapkan pendekatan etnografi dalam praktik literasi sebagaimana yang sarankan oleh Street (2001: 1-2).

Penelitian praktik literasi yang lebih menekankan pada sejarah hidup partisipan dalam mempraktikan literasi dilakukan oleh Deborah Brandt (2001). Dengan meneliti sejumlah orang dari berbagai elemen dan usia di Amerika, Brandt (2001: 4) mengakaji hubungan perkembangan literasi individu dengan perkembangan ekonomi di Amerika. Dia menganalisis keduanya dengan kerangka yang disebut dengan "sponsor" (orang atau institusi) yang mendukung dan mempengaruhi literasi seseorang. Menurut Brandt (2001: 189), perkembangan ekonomi menjadi bagian integral perkembangan literasi dari tahun ke tahun di Amerika. Perkembangan-perkembangan itu dipengaruhi oleh sponsor-sponsor literasi yang beragam yang kesemuanya berujung pada perkembangan ekonomi. Penelitian Brandt ini memberikan inspirasi pada penelitian ini tentang konsep sponsor dalam literasi mahasiswa UIN.

Tim peneliti dari Lancaster University dan University of Stirling (2007) melakukan sebuah proyek penelitian dengan tema "The Literacies for Learning in Further Education (LfLFE)." Tujuan utama penelitian ini adalah mengungkap hubungan antara praktik literasi dalam kehidupan seharihari mahasiswa, tuntutan literasi di kampus mereka dan penggunaan literasi di tempat kerja di mana mereka berharap untuk mendapatkan pekerjaan. Penelitian ini menyimpulkan 
bahwa terdapat berbagai tujuan dan mode-mode praktik literasi mahasiswa. Mahasiswa ternyata memiliki dan mempraktikan literasi dengan topik, gaya, tujuan dan mode yang beragam. Penelitian ini dapat dijadikan contoh bagaimana menggali keanekaragaman praktik literasi mahasiswa yang memampukan mereka dalam menjalani tantangan kehidupan di berbagai bidang.

Rackley (2010: 45) meneliti praktik literasi dalam konteks literasi agama di dua komunitas keagamaan anak muda yang berbeda. Fokus pembahasannya adalah motivasi praktik literasi serta konteks yang mempengaruhi praktik literasi tersebut. Menurutnya, pendekatan praktik literasi akan dapat memahami hubungan antara peristiwa membaca, menulis dan berbicara dengan struktur sosial dan budaya yang memengaruhinya. Praktik literasi anak-anak muda religius ini digali dengan metode kualitatif (Rackley, 2010: 45-46). Temuannya menunjukkan bahwa ada pola praktik literasi yang berbeda di dua komunitas religius anak muda. Satu kelompok mempelajari nilai-nilai keagamaan dalam kitab suci melalui penafsiran dan diskusi, sedangankan kelompok yang lain membatasi pada apa yang dikatakan kitab suci dengan cara membaca, mengucapkannya dan menghafalkan ayat-ayat kitab suci tersebut. Dengan begitu, menurutnya, praktik literasi sangat kontekstual sesuai dengan konteks dan tujuan — serta tentu ideologi-masing-masing komunitas tersebut. Penelitian Rackley memberikan inspirasi kepada penelitian ini terutama ketika menganalisis konteks, tujuan serta motivasi literasi.

Selain penelitian praktik literasi pada komunitas keagamaan, penelitian Dewayani dan Retningdyah dapat disebut sebagai contoh penelitian praktik literasi di komunitas 
yang sangat spesifik. Dewayani (2011) meneliti praktik literasi anak jalanan di Bandung, sedangkan Retnaningdyah meneliti praktik literasi Tenaga Kerja Wanita (TKW) di Hongkong. Keduanya menggunakan pendekatan kualitatif dengan konsep praktik literasi sebagai kerangka kerja.

Dewayani meneliti narasi-narasi anak jalanan yang menunjukkan praktik literasi dengan kerangka etnografi komunikasi (Dewayani, 2011: 27). Penelitian Dewayani ini mendokumentasikan cerita-cerita lisan dan produk-produk tulisan anak-anak jalanan untuk menemukan praktik literasi mereka. Praktik literasi anak jalanan kontekstual dengan kebutuhan mereka yang pragmatis, dan dalam kerangka pendefinisian diri mereka. Praktik literasi dapat memediasi konstruksi identitas kaum marginal (Dewayani, 2011: 243; Dewayani dan Retnaningdyah, 2017: 130 dan 141).

Praktik literasi sebagai kerangka pendefinisian diri juga terdapat pada buruh migran atau Tenaga Kerja Wanita di Hongkong (Dewayani dan Retnaningdyah, 2017: 144-145). Retnaningdyah meneliti praktik literasi wanita buruh migran melalui produk-produk literasi yang dihasilkan mereka, mulai dari buku, majalah maupun blog. Beberapa hal yang ditanyakan dalam penelitiannya adalah apa saja yang ditulis oleh para TKW tersebut dan apa alasannya serta apa yang mereka perjuangkan? (Dewayani dan Retnaningdyah, 2017: 56-57). Dengan metode yang sama dengan Dewayani, yakni pendekatan tekstual dan etnografi, ia menelusuri praktik literasi buruh migran. Menurut Retnaningdyah praktik literasi buruh migran wanita erat kaitannya dengan representasi identitas.

Menurut hasil penelitian Retnaningdyah, praktik literasi wanita buruh migran adalah alat untuk menyuarakan identitas 
diri dan komunitas. Literasi buruh migran juga berperan penting untuk mendobrak stereotip negatif mereka. Praktik literasi juga berfungsi memberikan seseorang kewenangan untuk menjadikan aktor utama bagi hidupanya, berani bersuara untuk dirinya sendiri dan komunitas. Dekontruksi pandangan negatif atas wanita buruh migran, menurut hasil penelitian Retnaningdyah tampak dari berbagai produk praktik literasi mereka dalam beragam modal literasi, yakni literasi digital (Dewayani dan Retnaningdyah, 2017: 102-104).

Adapun penelitian tentang praktik literasi di kalangan mahasiswa yang cukup sama dengan penelitian kali ini adalah penelitian Sari dan Pujiono (2017). Meski judul penelitiannya adalah 'Budaya literasi kalangan mahasiswa FBS UNY,' tetapi sesungguhnya mereka meneliti praktik literasi mahasiswa. Mereka meneliti praktik literasi membaca dan menulis mahasiswa dengan menanyakan frekuensi membaca dan menulis, teks apa yang dibaca dan ditulis, tujuan membaca dan menulis, membaca dan menulis karena tugas kuliah atau membaca karena hobi. Penelitian mereka menggunakan metode kualitatif dengan teknik wawancara dengan mahasiswa yang berjumlah 88 mahasiswa di satu fakultas.

Hasil penelitian Sari dan Pujiono (2017: 112) menunjukkan bahwa, kegiatan membaca dan menulis yang merupakan wujud dari budaya literasi di kalangan mahasiswa FBS UNY masih tergolong rendah dan kurang maksimal. Ada beberapa kendala yang ditemukan terkait dengan rendahnya budaya literasi tersebut, yakni kurangnya motivasi, malas, lelah dan jenuh, kurangnya referensi yang tersedia, sulitnya memunculkan ide untuk menulis, sulitnya merangkai kata dan kalimat. Kegiatan membaca dan menulis saling 
berkaitan. Saat kegiatan membaca kurang, kegiatan menulis pun terkendala. Sulitnya mahasiswa menemukan ide dan menuangkan ide dikarenakan keterbatasan referensi bacaan.

Penelitian tentang budaya literasi di lingkungan lembaga pendidikan tinggi keagamaan sebetulnya sudah pernah dilakukan, meskipun hanya sebatas pada satu fakultas (Gustini, Rohaniawati dan Imani, 2016). Penelitian tersebut bertujuan untuk mendeskripsikan tentang program budaya baca dan tulis mahasiswa di perguruan tinggi sebelum menggunakan peer tutor (tutor sebaya), mendeskripsikan proses implementasi pengembangan budaya baca dan tulis mahasiswa berbasis kecerdasan majemuk melalui tutor sebaya, menjelaskan hasil pengembangan budaya baca dan tulis mahasiswa berbasis kecerdasan majemuk melalui tutor sebaya. Penelitian ini menggunakan metode quasi eksperimen dengan jenis penelitian kuantitatif melalui proses pre tes, perlakukan dan pos tes. Penelitian ini sebetulnya melakukan sebuah uji coba pendekatan-yakni pendekatan multiple intelegence dan tutor sebaya-dalam mengembangkan budaya baca dan tulis mahasiswa. Penelitian ini dilakukan di Fakultas Tarbiyah dan Keguruan UIN Sunan Gunung Djati Bandung. Hasil penelitian tersebut menunjukkan bahwa terdapat perbedaan yang signifikan antara budaya baca dan tulis mahasiswa sebelum dan sesudah menggunakan tutor sebaya. Dengan menggunakan multiple intelegence dan tutor sebaya, mahasiswa terbiasa dan termotivasi membaca dan menulis melalui serangkaian program yang diujicobakan (Gustini, Rohaniawati dan Imani, 2016, 91). Hasil penelitian yang disebutkan terakhir di atas memberikan inspirasi pada penelitian kali ini tentang pentingnya komunitas dan konteks dalam sebuah praktik literasi. 
Tampak bahwa penelitian tentang praktik literasi terhadap mahasiswa pada lembaga pendidikan Islam yang serupa di beberapa daerah di Indonesia belum banyak dilakukan. Padahal, penelitian ini penting untuk mendapatkan pengetahuan tentang praktik literasi di lembaga pendidikan yang berada di bawah pembinaan Kementerian Agama. Penelitian ini pun belum semua mencakup wilayah Indonesia, hanya beberapa wilayah yang menjadi cakupan wilayah kerja Balai Litbang Agama Semarang. Data deskriptif ini sebetulnya penting sebagai gambaran awal sebelum menggali lebih dalam praktik literasi secara ideologis sebagaimana beberapa hasil penelitian yang telah diuraikan.

\section{Memahami Praktik Literasi: Konsep-konsep teoritis}

Konsep teoritis dalam buku ini mengadaptasi beberapa konsep penelitian literasi yang sudah pernah dilakukan, seperti yang dilakukan oleh PIRLS, CCSU dan tiga penelitian yang diuraikan terakhir. Sebagaimana yang telah dikemukakan dalam fokus bahasan, kerangka konseptual yang digunakan adalah praktik literasi membaca dan menulis. Namun sebelum itu, perlu diperjelas apa yang dimaksud dengan literasi.

Kata 'literasi' yang diambil dari bahasa Inggris, 'literacy,' awalnya diartikan sebagai "familiar with literature" (akrab dengan sastra), atau secara umum sebagai "well educated, learned" (orang yang berpendidikan atau terpelajar). Lalu sejak akhir abad ke-19 kata ini artinya menjadi 'kemampuan dalam membaca dan menulis teks' (UNESCO, 2005: 148). Ini yang kemudian literasi dalam bahasa Indonesia diartikan sebagai 'kemampuan menulis dan membaca.'

Sejak pertengahan abad ke-20, para sarjana mulai mengembangkan definisi literasi yang dihubungkan dengan 
berbagai disiplin ilmu. Fransman (2005: 3-19) merangkum beberapa konsepsi tentang literasi. Pertama, literasi sebagai sebuah keahlian. Kedua, literasi sebagai praktik dan situasi sosial. Ketiga literasi sebagai proses belajar. Keempat, literasi sebagai teks.

Pertama, literasi sebagai sebuah keahlian, terutama keahlian membaca dan menulis, bahkan sampai pada keahlian berhitung. Ini adalah definisi yang sangat umum dimengerti dan diterima oleh masyarakat. Pendekatan ini mengandaikan proses kognisi seseorang yang otonom, terlepas dari konteks, dalam belajar membaca, menulis dan berhitung. Pendekatan ini melupakan konteks pelajar yang selalu terkait dengan budayanya yang sedikit atau banyak masih mengandalkan kelisanan. Jadi dengan pendekatan ini, literasi hanya dipandang sebagai produksi pengetahuan melalui membaca dan menulis, sedangkan lisan dipandang kurang literat.

Oleh karena itu, sekarang ini, para ahli mulai memperluas pengertian keterampilan literasi (skill of literacies) tidak hanya dalam hal keterampilan membaca, menulis dan berhitung. Perluasan pengertian ini lebih sebagai upaya untuk menanggapi kebutuhan hidup manusia di abad 21 (Fransman, 2005: 8). Beberapa ahli, seperti Street (2003: 77) menyarankan istilah atau konsep yang lebih berguna dan bermakna untuk abad 21, yakni 'multiliterasi' (multiple literacies) untuk beragam konteks tempat dan waktu literasi.

Multiliterasi adalah 'sebuah cara membaca dunia' dalam beragam konteks atau kepentingan, seperti ilmu pengetahuan, media, visual, informasi dan teknologi atau lainnya, yang intinya adalah mengandaikan beragam kompetensi yang harus dimiliki untuk mengakses pengetahuan dan informasi serta memproduksi makna dari pengetahuan dan informasi 
yang didapat tersebut. Multiliterasi tersebut mencakup literasi informasi, literasi media baru, literasi teknologi komputer dan digital, literasi visual, literasi lingkungan, literasi politik dan kewarganegaraan, literasi budaya (Fransman, 2005: 8-9) dan literasi agama (Prothero, 2008: 11-12).

Sekarang ini, konsep-konsep 'literasi informasi', 'literasi media' dan 'literasi visual' sering digunakan secara bergantian. Ini berawal dari pandangan literasi sebagai keterampilan teknis yang netral, yang kemudian bergeser kepada penerapan keterampilan ini secara kritis dan untuk tujuan transformatif(Hull, dkk., 2003). Misalnya dalam kasus literasi informasi, istilah dalam arti ini biasanya mengacu pada kemampuan untuk mengakses dan menggunakan berbagai sumber informasi untuk memecahkan kebutuhan informasi. Namun, hal tersebut juga dapat didefinisikan sebagai pengembangan serangkaian keterampilan yang kompleks yang memungkinkan orang mengekspresikan, mengeksplorasi, mempertanyakan, mengkomunikasikan dan memahami arus gagasan di antara individu dan kelompok dalam lingkungan teknologi yang berkembang. Demikian pula dengan literasi media, yang mengacu pada pengetahuan dan pemanfaatan berbagai media. Tapi literasi media juga bisa menyiratkan pemahaman kritis tentang subjektivisme, bias, dan tujuan tersembunyi yang lebih berbahaya di dalam media. Penekanannya dari semua pengertian itu adalah pada keterampilan penyelidikan kritis (Fransman, 2005: 10).

Pendekatan 'otonom' atau 'keterampilan' untuk memahami literasi tidak diragukan lagi merupakan hal yang paling dominan dan yang paling praktis untuk tujuan pemantauan, penilaian dan evaluasi. Kemampuan literasi bisa dengan mudah diujicobakan dengan hasil belajar dan dinilai 
dengan cara yang sama seperti 'prestasi' dalam pendidikan formal.

Namun, pemahaman seperti di atas bukan tanpa keterbatasan. Street (2001: 7) berpendapat bahwa model ini menyamarkan asumsi budaya dan ideologis yang mendukungnya dan menghadirkannya literasi seolah-olah bersifat netral, otonom dan universal. Dia mengklaim bahwa dalam praktiknya, pendekatan dominan berdasarkan model otonom hanya menerapkan konsepsi literasi Barat (atau perkotaan atau bias laki-laki) ke budaya lain.

Muncul sebuah pendekatan yang menekankan pemahaman tentang literasi dalam konteks sosial dan budaya. Pendekatan baru ini disebut sebagai 'New Literacy Studies' (NLS) (Gee, 2000; 177; Lankshear dan Knobel, 2011: 2728). NLS berfokus pada makna sehari-hari dan penggunaan literasi dalam konteks budaya tertentu dan/berhubungan langsung dengan bagaimana kita memahami program literasi, yang kemudian diselidiki secara etnografis (Street, 2005: 14).

Melalui pendekatan NLS, alih-alih menghargai praktik literasi tertentu yang sudah akrab dengan budaya peneliti sendiri, peneliti menggali apa yang dimaksud literasi di antara orang-orang yang mereka teliti, serta konteks sosial dan motivasi apa yang mendorong mereka membaca dan menulis untuk mendapatkan makna. Menurut pandangan NLS, banyak orang yang diberi label 'buta huruf' atau 'rendah literasinya' dalam model literasi otonom, mungkin dari sudut pandang yang lebih "peka budaya," yakni NLS, dapat dipandang secara signifikan telah menggunakan praktik literasi untuk tujuan tertentu dan dalam konteks spesifik (Street, 2005: 14$15)$. 
Konsep kunci dalam NLS adalah konsep tentang 'peristiwa literasi' dan praktik literasi. Shirley Brice Heath (dalam Dewayani dan Retnaningdyah, 2017: 10) mencirikan 'peristiwa literasi' sebagai 'peristiwa apapun di mana suatu tulisan merupakan bagian integral dari interaksi para partisipan dan proses interpretasi teks tersebut.' Sementara itu, 'praktik literasi' tidak hanya mencakup peristiwa yang bisa dilihat, tetapi juga nilai-nilai dan perilaku orang-orang yang terlibat dalam peristiwa literasi (Barton dan Hamilton, 2000: 7-8). Dalam praktik literasi, pertanyaan yang biasa muncul adalah tentang alasan, motif, tujuan praktik literasi atau pilihan-pilihan jenis dan modal literasi dalam praktik literasi tersebut.

Pendekatan NLS telah dikritik oleh beberapa ilmuwan, yang mengklaim bahwa hal itu terlalu menekankan lokalitas dan kurang memahami bagaimana kekuatan ekstrinsik (misalnya pemerintahan kolonial, misionaris, komunikasi internasional, globalisasi ekonomi) telah memengaruhi pengalaman 'lokal' komunitas tertentu (Brandt dan Clinton, 2002: 338). Dengan terlalu memperhatikan pengalaman lokal, penilaian kemampuan literasi menjadi sangat subyektif. Namun, pandangan kontekstual terhadap literasi sesungguhnya pada kenyataan digunakan untuk lebih menghargai keragaman praktik literasi masyarakat yang saling berhubungan antara yang lokal dan global.

\section{Konsep praktik literasi dalam buku ini}

Sebagaimana telah diuraikan, bagi beberapa orang, literasi telah menjadi istilah yang direduksi sebagai "kemampuan membaca" saja. Ahli lain mempertanyakan mengapa menggunakan literasi sebagai metafora untuk segala 
hal lainnya. Namun, mereka yang menganjurkan pendekatan multimodal, multiliterasi, dan literasi fungsional dalam NLS berpendapat bahwa 'membaca' masih merupakan bagian penting dari literasi, bukan hanya membaca teks, tapi juga simbol lain dalam konteks yang berbeda untuk tujuan yang berbeda pula. Pengertian inilah yang akan digunakan dalam penelitian ini. Pengertian literasi seperti ini mengandaikan bahwa meskipun pengertian literasi telah meluas ke berbagai aspek atau bidang dan sarat konteks, tetapi membaca dan menulis sebagai inti dari kemampuan atau kompetensi literasi tetap tak bisa dilepaskan. Pengertian seperti ini tampaknya juga digunakan oleh Dewayani dan Retnaningdyah (2017: 9). Menurut mereka, literasi adalah kegiatan yang berpusat pada teks, baik membaca maupun menulis untuk beragam tujuan dan konteks.

Buku ini mengartikan literasi sebagai/keterampilanketerampilan yang berpusat pada 'teks' (dengan beragama jenis dan modalnya), terutama keterampilan membaca dan menulis, yang digunakan dalam konteks tertentu, untuk tujuan tertentu, yang dilakukan dalam lingkup pembelajaran di lembaga pendidikan atau masyarakat secara umum. Dengan menerima kritik yang diajukan pada pandangan sosial dan kontekstual terhadap literasi yang terlalu bernuansa lokalitas, maka penelitian ini justru menggali seluas mungkin praktik yang berpusat pada teks dengan konteks dan tujuan tertentu di kalangan mahasiswa. Sehingga yang dilihat dalam praktik literasi ini adalah ragam teks yang dibaca dan ditulis, tujuan membaca dan menulis, di mana ia membaca dan menulis, dan partisipasi terhadap sumber-sumber literasi (akses perpustakaan dan media online). Dengan menggunakan frasa 'praktik literasi,' penelitian ini menghindari penilaian 
(assessment) tentang angka tingkat literasi yang dicapai oleh mahasiswa, tetapi menggali sebanyak mungkin bentuk dan pola literasi yang berpusat pada peristiwa membaca dan menulis 'teks.'

Praktik literasi di dalam penelitian ini tidak hanya melihat pada aksi atau keterampilan membaca dan menulis subyek yang diteliti, tetapi mencakup perilaku, sikap dan nilai-nilai seseorang terhadap aksi membaca dan menulis. Perilaku, sikap dan nilai-nilai tentang aksi membaca dan menulis seseorang ini juga berkaitan dengan konteks sosial, budaya dan ideologi yang melingkupinya. Penelitian tentang praktik literasi berarti menanyakan sikap, perilaku dan nilainilai tentang membaca dan menulis yang dimiliki seseorang serta konteks-konteks yang meliputinya.

Menurut Pardoe dan Ivanic sebagaimana dikutip oleh Martyn Edward (2012: 4), ada sembilan aspek praktik literasi membaca dan menulis. Sembilan aspek tersebut adalah: topik atau isu bacaan atau tulisan, gaya dan konvensi bacaan atau tulisan, mode-mode dan teknologi bacaan atau tulisan, tujuan membaca dan menulis, fleksibilitas dan kendala-kendala, aksi dan proses/tahapan, audiens, peran dan identitas, interaksi dan kolaborasi, serta konteks dan infrastruktur.

Dengan demikian, penelitian praktik literasi adalah penelitian yang membahas tentang; (1) subyek yang mempraktikan literasi, di dalamnya terdapat sikap, perilaku, motif-motif atau tujuan-tujuan literasi; (2) konteks, di dalamnya memeriksa konteks dan infrastruktur yang menyituasikan praktik literasi; (3) produk atau artefak literasi, di dalamnya terdapat pembahasan tentang topik atau isu bacaan atau tulisan, gaya dan konvensi bacaan atau tulisan, mode-mode dan teknologi bacaan atau tulisan. 
Gambar 1. Skema Penelitian Praktik Literasi

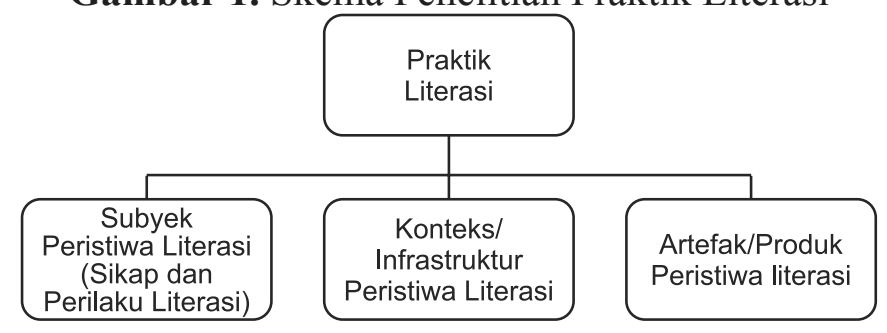

\section{Literasi membaca}

Membaca, menurut pengertian yang sederhana, berarti suatu proses yang dilakukan serta dipergunakan oleh pembaca untuk memperoleh pesan yang hendak disampaikan oleh penulis melalui media kata/bahasa tulis (Tarigan, 2008: 7). Adapun membaca dalam konsep literasi, diartikan sebagai keterampilan atau usaha memahami, menggunakan, merefleksi dan melibatkan diri dalam berbagai jenis teks untuk mencapai tujuan. Dalam hal ini, membaca bertujuan mengembangkan pengetahuan dan potensi seseorang, serta untuk berpartipisasi dalam masyarakat (Abidin, Mulyati dan Yunansah, 2017: 165). Progress in International Reading Literacy (PIRLS) mendefinisikan literasi membaca sebagai kemampuan untuk memahami dan menggunakan bentuk bahasa tertulis yang dibutuhkan oleh masyarakat dan/atau diperlukan oleh individu.

Pembaca muda dan dewasa bisa membangun makna dari berbagai teks. Mereka membaca untuk belajar, untuk berpartisipasi dalam komunitas pembaca di sekolah atau lembaga pendidikan lainnya dan kehidupan sehari-hari, serta untuk kesenangan (Mullis, Martin, Kennedy, Trong, Sainsbury, 2009: 11).

Pengertian dan pandangan ini mencerminkan teori literasi 
membaca sebagai proses yang konstruktif dan interaktif (Alexander dan Jetton, 2000: 286). Pembaca dianggap aktif membangun makna dan mengetahui strategi membaca yang efektif dan bagaimana merefleksikan bacaan (Afflerbach \& Cho, 2009; 69). Mereka memiliki sikap positif terhadap membaca dan membaca untuk rekreasi. Pembaca dapat belajar dari sejumlah jenis teks, memperoleh pengetahuan tentang dunia dan diri mereka sendiri dari membaca teks. Mereka dapat menikmati dan mendapatkan informasi dari banyak bentuk multimodal teks yang disajikan dalam masyarakat saat ini (Organisation for Economic Cooporation and Development, 1999: 19-20).

Literasi membaca ini adalah termasuk bentuk tulisan tradisional seperti buku, majalah, dokumen, dan surat kabar. Literasi membaca juga mencakup teknologi informasi dan komunikasi, seperti internet, e-mail, dan pesan teks, serta teks yang terintegrasi dengan berbagai media video dan televisi (Leu, Kinzer, Coiro, dan Henry, 2013: 1156).

\section{a. Tujuan dan motivasi literasi membaca}

Sebagaimana yang diajukan oleh PIRLS (Mullis, Martin, Kennedy, Trong, Sainsbury, 2009: 13), setidaknya ada dua tujuan literasi membaca. Pertama, membaca untuk pengalaman sastra. Kedua, membaca untuk memperoleh dan menggunakan informasi.

Literasi membaca berhubungan langsung dengan alasan mengapa orang membaca. Secara umum, alasan ini termasuk membaca untuk kepentingan pribadi dan kesenangan, membaca untuk berpartisipasi dalam masyarakat, dan membaca untuk belajar. Bagi pembaca muda, termasuk mahasiswa di dalamnya, penekanan ditempatkan pada 
membaca untuk minat atau kesenangan dan membaca untuk belajar (Mullis, Martin, Kennedy, Trong, Sainsbury, 2009: 19).

Masing-masing tujuan membaca ini sering dikaitkan dengan jenis teks tertentu. Misalnya, membaca untuk pengalaman sastra sering dilakukan melalui membaca fiksi, namun membaca untuk memperoleh dan menggunakan informasi umumnya terkait dengan artikel informatif dan teks instruksional pembelajaran. Namun, tujuan membaca tidak harus sesuai secara ketat dengan jenis teks. Misalnya, biografi atau otobiografi bisa bersifat informasi atau sastra, namun juga dapat mencakup dua tujuan sekaligus. Karena selera dan minat orang sangat bervariasi, hampir semua teks bisa memenuhi salah satu dari tujuan di atas (Mullis, Martin, Kennedy, Trong, Sainsbury, 2009: 20).

Pembaca, dalam literasi membaca sastra, terlibat dalam kejadian, tindakan, konsekuensi, karakter, atmosfer, perasaan, dan gagasan yang dibayangkan dalam teks, dan menikmati bahasa sastra tersebut. Untuk memahami dan menghargai sastra, pembaca harus masuk pada pengalaman, perasaan, apresiasi bahasa dan pengetahuannya tentang bentuk sastra pada teks. Bagi pembaca muda, sastra menawarkan kesempatan untuk mengeksplorasi situasi dan perasaan yang belum mereka hadapi. Biasanya bentuk utama teks sastra yang digunakan dalam penilaian PIRLS adalah narasi fiksi. Dengan perbedaan kurikulum dan budaya di negara-negara peserta survei, sulit bagi PIRLS untuk memasukkan beberapa jenis teks sastra (Mullis, Martin, Kennedy, Trong, Sainsbury, 2009: 21).

Adapun pembaca dalam literasi membaca informasi tidak terlibat dengan dunia imajinatif, namun dengan aspek dunia 
yang sebenarnya. Melalui teks informasi, seseorang dapat memahami bagaimana dunia ini dan telah ada, dan mengapa segala sesuatunya berjalan sebagaimana mestinya. Pembaca bisa melampaui perolehan informasi dan menggunakannya dalam penalaran dan tindakan. Teks informasi tidak perlu dibaca dari awal sampai akhir; pembaca dapat memilih bagian yang mereka butuhkan. Organisasi teks yang berbeda membuat tuntutan yang berbeda pada pembaca. Dapat dicatat bahwa teks informasi memiliki judul atau jenis organisasi teks yang teratur.

Teks informasi secara kronologis menyajikan gagasan yang ingin disampaikan. Teks semacam itu dapat menceritakan kejadian, misalnya fakta sejarah atau catatan harian, catatan pribadi, atau surat. Biografi dan otobiografi, yang merinci kejadian kehidupan nyata, adalah juga kelompok teks utama jenis ini. Teks kronologis yang disusun bersifat prosedural, misalnya resep dan instruksi juga termasuk teks informatif. Di sini, bentuk imperatif sering digunakan dan pembaca diharapkan tidak hanya sekedar mengerti tapi juga bertindak sesuai dengan apa yang dibaca.

Terkadang informasi dan gagasan disusun secara logis daripada secara kronologis. Misalnya, teks hasil penelitian dapat menjelaskan sebab dan akibat, artikel hasil penelitian dapat membandingkan dan membedakan hal-hal seperti masyarakat atau cuaca, dan editorial dapat menyajikan argumen dan opisisi atau mengemukakan pandangan dengan bukti pendukung. Teks persuasif bertujuan secara langsung mempengaruhi pandangan pembaca, seperti dalam presentasi masalah dan solusi yang disarankan. Dalam diskusi dan persuasi, pembaca harus mengikuti perkembangan gagasan dan membawa teks tersebut ke dalam pikiran kritis untuk 
membentuk pendapatnya sendiri.

Terkadang teks informasi adalah teks ekspositori, yakni menyajikan penjelasan atau menggambarkan orang, kejadian, atau benda. Dalam sebuah organisasi tematik, aspek topik dikelompokkan dan dijelaskan bersama dalam teks. Harus diperhatikan bahwa penyajian informasi tidak perlu berupa teks yang berkelanjutan. Bentuk teks meliputi brosur, daftar, diagram, dan gambar yang menyerukan tindakan pembaca seperti iklan atau pengumuman. Harus ditekankan bahwa satu teks informasi sering menggunakan satu atau lebih cara menyajikan informasi. Bahkan potongan informasi yang seharusnya sering didokumentasikan dengan tabel atau diilustrasikan dengan gambar dan diagram (Mullis, Martin, Kennedy, Trong, Sainsbury, 2009: 22-23).

Tujuan literasi membaca ini dapat juga dihubungkan dengan teori motivasi membaca. Guthrie dan Wigfield (2000: 407) membagi motivasi membaca menjadi dua, yakni motivasi intrinsik dan motivasi ekstrinsik. Motivasi intrinsik membaca mengacu pada kenikmatan membaca seseorang yang dilakukan untuk kepentingan mereka sendiri dan biasanya dilakukan sepanjang waktu.

Guthrie dan Wigfield (2000: 407) membedakan berbagai aspek motivasi intrinsik untuk membaca, yakni keingintahuan, keterlibatan, dan preferensi terhadap tantangan. 'Keingintahuan' adalah partisipasi seseorang dalam kegiatan untuk memenuhi keinginan untuk belajar dan memahami dunia disekitarnya. 'Keterlibatan' mengacu pada kenikmatan seseorang dalam penyerapan sebuah teks. 'Preferensi untuk tantangan' adalah keinginan untuk menemukan literatur yang rumit atau untuk memahami gagasan kompleks dalam teks. Aspek motivasional ini bersifat independen. Seorang anak 
mungkin tergolong tinggi dalam satu motivasi (misalnya, keterlibatan) dan rendah pada motivasi yang lain (misalnya, preferensi untuk tantangan), meskipun aspek motivasi ini sering ada secara bersama-sama.

Motivasi ekstrinsik untuk membaca adalah keinginan untuk menerima pengakuan, penghargaan, atau insentif ekstrinsik. Motivasi ekstrinsik bukan sekadar kebalikan dari motivasi intrinsik. Sebenarnya, keduanya berkorelasi positif. Namun, motivasi ekstrinsik biasanya dikaitkan dengan keinginan untuk menyelesaikan tugas daripada untuk memahami atau menikmati teks atau tugas. Selanjutnya, motivasi ekstrinsik dapat menghasilkan perilaku "selfterminating" (membatasi diri). Ketika seseorang telah mendapatkan insentif, mereka berhenti membaca. Insentif ekstrinsik sering membuat siswa semakin bergantung pada penghargaan dan pengakuan (Guthrie dan Wigfield, 2000: 407).

\section{b. Preferensi dalam membaca}

Preferensi dalam membaca adalah pilihan-pilihan seseorang dalam menentukan materi-materi bacaan atau literatur. Sebagaimana telah disinggung di atas, preferensi bacaan tergantung pada tujuan dan motivasi membaca. Misalnya, survei The Reading Connects (Clark dan Foster, 2005: 20) menunjukkan bahwa ketika siswa ditanyai jenis materi apa yang mereka baca di luar kelas, maka majalah, situs web, pesan teks, lelucon dan buku/majalah tentang program TV muncul sebagai yang paling populer. Lebih dari separuh murid juga mengindikasikan membaca e-mail, fiksi, komik, dan surat kabar, sehingga bacaan tersebut juga merupakan pilihan populer. Ketika ditanya secara khusus tentang jenis 
fiksi apa, maka cerita petualangan, komedi dan horor/hantu adalah jenis yang paling sering dipilih. Hanya 5\% murid yang tidak membaca fiksi.

Jika diperhatikan, preferensi dalam membaca memang sangat terkait dengan tujuan, motivasi dan materi bacaan. Dari segi materi, pilihan bacaan akan terlihat dalam bentuk medianya (buku, majalah, surat kabar) atau genrenya (fiksi dan non fiksi). Genre fiksi pun dapat diuraikan lagi menjadi genre fiksi humor, dramatis, petualangan atau horror. Begitu juga dengan genre non fiksi, dapat dibagi lagi menjadi beragam jenis teks, seperti teks deskriptif, argumentatif dan persuasif.

\section{c. Sikap dan perilaku membaca}

Literasi membaca tidak hanya melibatkan kemampuan untuk membangun makna dari berbagai teks, tapi juga sikap dan perilaku yang mendukung literasi membaca sepanjang hayat. Sikap dan perilaku seperti itu berkontribusi pada realisasi potensi individu dalam masyarakat yang terpelajar. Sebagian besar kuesioner tentang literasi membaca yang diajukan oleh PIRLS membahas sikap siswa terhadap membaca dan kebiasaan atau perilaku membaca mereka. Kuesioner yang dibuat itu dapat menjelaskan perilaku dan sikap serta konteks rumah dan sekolah untuk membaca (Mullis, Martin, Kennedy, Trong, Sainsbury, 2009: 15).

Perilaku membaca ini dapat dilihat pada bagaimana seseorang melibatkan diri dalam aktivitas membaca, seperti pergi dan membaca di perpustakaan, membeli buku, menghabiskan waktu dengan membaca daripada bermain video game, dan mendiskusikan sebuah bacaan (buku atau artikel). Membaca mandiri dan mendiskusikan bacaan di 
berbagai tempat di luar lingkungan kelas menjadi salah bentuk perilaku literasi membaca (Mullis, Martin, Kennedy, Trong, Sainsbury, 2009: 53).

Sikap positif terhadap membaca mungkin merupakan salah satu penanda terpenting pembaca seumur hidup. Sikap pembaca adalah perasaan, pandangan dan keyakinan seseorang terhadap aktivitas membaca (Clark dan Rumbold, 2006: 17). Seseorang pembaca dengan baik biasanya menampilkan sikap yang lebih positif daripada seseorang yang belum memiliki banyak keberhasilan dalam membaca. Seseorang yang telah mengembangkan sikap positif dan konsep diri tentang membaca juga lebih cenderung memilih membaca untuk rekreasi atau kesenangan (reading for pleasure). Kegiatan membaca semacam itu selanjutnya dapat meningkatkan minat dan kepercayaan siswa dalam membaca. Ketika anak-anak membaca pada waktunya sendiri, mereka tidak hanya menunjukkan sikap positif, mereka juga mendapatkan pengalaman berharga dalam membaca berbagai jenis teks yang kemudian menjadi perkembangan mereka sebagai pembaca yang mahir (Mullis, Martin, Kennedy, Trong, Sainsbury, 2009: 53-54).

\section{Literasi menulis}

Menulis adalah suatu keterampilan berbahasa yang dipergunakan untuk berkomunikasi secara tidak langsung melalui media kata/bahasa (Tarigan, 2013: 3). Sedangkan dalam konsep literasi, menulis adalah proses berulang yang dilakukan penulis untuk merevisi ide-idenya, mengulangi tahapan-tahapan menulis, hingga mampu mencurahkan ide tersebut dalam sebuah bentuk tulisan. Jadi literasi menulis mengacu pada proses dan hasil sekaligus. Menulis sebagai 
proses karena mengharuskan proses yang berulang dalam revisi dan tahapan menulis, dan sebagai hasil karena literasi menulis akan menghasilkan produk tulisan yang berisi gagasan-gagasan penulis. Dalam menulis, biasanya penulis mempertimbangkan pembaca, tujuan penulisan dan konteks (Abidin, Mulyati dan Yunansah, 2017: 206). Keterampilan menulis adalah salah satu tujuan pembelajaran literasi dalam konteks multiliterasi di abad ke-21 (Abidin, Mulyati dan Yunansah, 2017: 29).

Literasi menulis tidak terlepaskan dengan literasi membaca (Dewayani, 2017: 140). Karena itu, beberapa bahasan dalam literasi membaca dapat diterapkan dalam literasi menulis, seperti tujuan menulis (apakah menulis untuk tujuan kesastraan atau untuk menyampaikan informasi), preferensi dalam menulis (jenis materi apa yang lebih suka ditulis, fiksi atau non fiksi), motivasi dalam menulis (motivasi pengembangan diri atau karena ada tugas belajar), dan perilaku dan sikap dalam menulis (menulis di mana pun, kapan pun, aktif dalam kegiatan menulis, sikap positif terhadap menulis).

\section{Konteks yang mendukung literasi membaca dan menulis}

Anak-anak muda memperoleh kemampuan baca-tulis melalui berbagai aktivitas dan pengalaman dalam konteks yang berbeda. Selama tahun-tahun sekolah dasar mereka, anak-anak mengembangkan keterampilan, perilaku, dan sikap yang terkait dengan literasi membaca terutama di rumah dan sekolah. Berbagai sumber dan aktivitas telah memupuk atau tidak memupuk kemampuan literasi mereka, termasuk hal-hal yang terjadi sebagai bagian kegiatan sehari-hari yang alami 
dan informal. Kegiatan yang kurang terstruktur dapat menjadi sangat penting dalam membantu anak-anak mengembangkan literasi membaca sebagai kegiatan yang lebih terstruktur yang terjadi di kelas sebagai bagian dari instruksi membaca dan menulis. Selain itu, lingkungan lain mendukung, dan hubungan antara rumah dan sekolah juga merupakan elemen penting dalam literasi membaca dan menulis.

\section{a. Konteks rumah atau keluarga}

Banyak penelitian telah memberi wawasan tentang pentingnya lingkungan rumah untuk literasi membaca dan menulis anak-anak dan remaja. Karakteristik rumah tertentu dapat menciptakan iklim yang mendorong anak untuk mengeksplorasi dan bereksperimen dengan bahasa dan berbagai bentuk teks. Orang tua dan anggota keluarga lainnya dapat menanamkan keyakinan tentang membaca dan menulis (Mullis, Martin, Kennedy, Trong, Sainsbury, 2009: 40).

Beberapa penelitian juga menunjukkan adanya hubungan antara kondisi sosial-ekonomi orang tua dan sumber-sumber belajar atau literasi di rumah dengan kemampuan literasi anak atau remaja dalam membaca dan menulis. Dukungan orang tua juga dikatakan memberikan dampak bagi pengembangan literasi anak. Hal yang penting juga adalah perilaku dan sikap orang tua terhadapkegiatanmembaca danmenulis memberikan dampak dalam literasi anak. Rumah menyediakan model dan panduan langsung dalam praktik literasi yang efektif. Orang tua dan anggota keluarga lainnya menyampaikan sikap kepada anak-anak mereka untuk membaca dan menghargai teks. Keterlibatan orang tua dalam banyak kegiatan literasi mendorong sikap positif anak terhadap membaca dan menulis. Orang tua yang mempromosikan pandangan bahwa 
membaca adalah kegiatan yang berharga dan berarti memiliki anak yang termotivasi untuk menikmati kegiatan membaca yang menyenangkan (reading for pleasure) (Mullis, Martin, Kennedy, Trong, Sainsbury, 2009: 41-42).

\section{b. Konteks lembaga pendidikan (sekolah dan kampus)}

Meski rumah bisa menjadi lingkungan yang baik untuk mengembangkan kemampuan literasi, bagi kebanyakan anak, sekolah tetap menjadi lokasi utama untuk pembelajaran formal dan kegiatan pendidikan. Karakter sekolah yang kondusif, misalnya karena dekat dengan sumber-sumber belajar, dukungan manajemen dan tenaga pengajar, memberikan pengaruh yang baik bagi literasi. Begitu juga iklim akademik yang membangun gairah aktivitas belajar juga memberikan dampak bagi kualitas literasi. Kehadiran perpustakaan atau pusat multi media sangat relevan untuk mengembangkan literasi membaca dan menulis.

Perpustakaan dan pusat multi media menjadi penting dilihat dalam konteks infrastruktur literasi (Black, Crest dan Volland, 2001: 215-225; Laksono dan Retnaningdyah, 2018: 2). Infrastruktur literasi adalah fasilitas yang mendukung literasi. Untuk konteks lembaga pendidikan, seperti kampus atau sekolah, selain perpustakaan dan pusat multi media, kurikulum literasi juga menjadi salah satu infrastruktur yang harus ada di kampus (Cohen dan Bhatt, 2012: 118). Faktor infrastruktur ini ikut menyumbang pada masalah kualitas literasi. Dalam kajian praktik literasi, kondisi infrastruktur bukan semata dilihat secara deskriptif, tetapi juga melihat pemanfaatnya oleh subyek literasi. 


\section{Meneliti dan Menyajikan Praktik Literasi Mahasiswa UIN: Catatan Metode}

Buku ini berdasarkan sebuah penelitian yang dirancang sebagai pendekatan kualitatif. Tujuannya adalah mendeskripsikan pola praktik literasi mahasiswa UIN di Yogyakarta, Jawa Tengah, Jawa Timur (Surabaya dan Malang), Nusa Tenggara Barat dan Kalimantan Selatan, dan kondisi infrastruktur yang mendukung praktik literasi tersebut. Karena merupakan penelitian kualitatif dengan desain studi multi kasus, maka penelitian ini tidak bermaksud untuk melakukan generalisasi sebagaimana penelitian kuantitatif. Penelitian ini bermaksud membangun pola praktik literasi dalam suatu konteks atau latar penelitian tertentu, yang hasil pola tersebut dapat digunakan sebagai replika (Yin, 97: 56) dan pelajaran (lesson learned) untuk kasus dengan latar atau konteks yang lain.

Subyek penelitian ini adalah mahasiswa UIN di Yogyakarta, Semarang, Surabaya, Malang, Mataram dan Banjarmasin. Himpunan Mahasiswa Jurusan (HMJ) dipandang menjadi representasi mahasiswa di masing-masing jurusan atau program studi di setiap fakultas. Selain itu, mahasiswa-mahasiswa yang aktif di HMJ dapat dipandang sebagai model ideal untuk merumuskan pola praktik literasi. Karena itu, partisipan utama dalam penelitian ini adalah para pengurus HMJ di setiap kampus. Selain para pengurus HMJ, partisipan penelitian adalah mereka juga yang aktif di dalam komunitas-komunitas yang terkait dengan praktik literasi. Data dari partisipan dikumpulkan sebanyak mungkin hingga mencapai tingkat kejenuhan data (data saturation) dalam penelitian kualitatif sebagaimana yang disarankan oleh Creswell (2007: 271). 
Data dalam penelitian ini dikumpulkan dengan teknik observasi, wawancara, diskusi kelompok terfokus (FGD), studi dokumen dan dilengkapi dengan online atau e-mail interview. Observasi dilakukan untuk mendapatkan gambaran situasi kampus yang menjadi lokasi riset, lokasi-lokasi yang terdapat peristiwa literasi (misalnya perpustakaan kampus, perpustakaan fakultas, jurusan, sekretariat HMJ, dan kelas). Untuk mendokumentasikan hasil observasi ini dilakukan pengambilan foto terhadap obyek observasi.

Selanjutnya wawancara dilakukan terhadap mahasiswa yang tergabung atau menjadi pengurus HMJ, baik dari fakultas keagamaan, maupun non keagamaan. Wawancara dilakukan untuk menggali informasi tentang praktik literasi. Selain wawancara kepada mahasiswa, wawancara juga dilakukan kepada sejumlah dosen untuk mendapatkan pandangan tentang praktik literasi mahasiswa. Penggalian informasi juga dilakukan melalui diskusi kelompok terfokus untuk lebih menggali informasi secara luas tentang praktik literasi mahasiswa. Diskusi kelompok terfokus ini dilakukan dengan melibatkan para pengurus atau ketua-ketua HMJ, baik dari fakultas-fakultas keagamaan maupun dari fakultas nonkeagamaan. Wawancara juga dilakukan terhadap sejumlah aktivis yang sangat terkait dengan praktik literasi, seperti aktivis lembaga pers mahasiswa, kelompok diskusi dan mahasiswa-mahasiswa yang aktif mengembangkan minat kepenulisan. Selain dengan teknik wawancara, data juga digali dengan mendokumentasikan 'artefak literasi' yang berupa dokumen teks hasil praktik literasi.

Penelitian ini juga menggunakan daftar pertanyaan kualitatif dengan cara online atau e-mail interview dalam Google form. Penggunaan online atau e-mail interview dalam 
penelitian kualitatif absah secara metodologis, terlebih pada masa perkembangan teknologi informasi sekarang ini dan konteks generasi pada partisipan yang diteliti pada era digital sekarang (Redlich-Amirach dan Hagginbottom, 2014: 1-14; Meho, 2006: 1284-1295).

Online atau e-mail interview ini dilakukan untuk melibatkan lebih banyak lagi mahasiswa, baik yang menjadi pengurus maupun yang tidak. Daftar pertanyaan didesain untuk menggali informasi praktik literasi mahasiswa. Penggunaan daftar pertanyaan kualitatif diberikan kepada sebanyak mungkin mahasiswa sehingga memungkinkan 'kejenuhan data' yang menjadi syarat dalam penelitian kualitatif. Daftar pertanyaan disebarkan berjejaring melalui perantaraan para pimpinan aktivis HMJ dan komunitas mahasiswa. Hasil jawaban yang kredibel diambil sebagai data. Penyebaran daftar pertanyaan ini berhasil mengumpulkan respon mencapai 1007 mahasiswa yang berpartisipasi dalam menjawab pertanyaan.

Setelah semua data terkumpul, selanjutnya dilakukan input dan koding data dalam sebuah perangkat yang sudah disediakan. Setelah semua diinput dan dikoding, langkah selanjutnya adalah analisis. Analisis dalam penelitian ini bertujuan untuk melakukan identifikasi dan interpretasi pola praktik literasi.

Berdasarkan data observasi, wawancara, diskusikelompok terfokus dan online interview peneliti memunculkan daftar deskriptif dari semua praktik literasi. Peneliti mengategorikan data dengan menggunakan kerangka kerja analitis sembilan aspek praktik literasi, sebagaimana yang telah dijelaskan dalam konsep teoritis. Peneliti lalu mengklasifikasikan aspek-aspek tersebut dan mengidentifikasi melalui 
interpretasi ke dalam tema-tema yang muncul sesuai dengan tujuan penelitian. Setelah terbentuk tema-tema bedasarkan kategorisasi data yang ada, selanjutnya dilakukan narasi atas tema berdasarkan data yang tersedia. Analisis juga dilakukan dengan memberikan penjelasan-penjelasan yang didapat dari hasil informasi lain atau hasil penelitian terdahulu yang relevan.

Pembahasan buku ini dimulai sejak bab dua. Bab ini tentang gambaran latar sasaran penelitian. Bab ini menjelaskan konteks ruang dan waktu praktik literasi di lokasi yang menjadi sasaran penelitian. Bab ini dibagi menjadi dua bagian, pertama pembahasan tentang latar ruang atau tempat yang menjadi latar penelitian, yakni kampus UIN, dan kedua pembahasan tentang latar waktu yang membingkai partipisan penelitian, yakni abad milenial.

Uraian tentang hasil peneltian sebetulnya sudah mulai di bab sebelumnya, tetapi semakin intensif dijabarkan di dalam bab tiga. Bab ini mengulas tentang kondisi infrastruktur literasi, yakni perpustakaan di masing-masing kampus. Setelah menggambarkan kondisi perpustakaan, bab ini juga menganalisis tentang pemanfaatan perpustakaan bagi praktik literasi mahasiswa. Bab ini juga mengevaluasi kurang siapnya kondisi infrastruktur ilmu pengetahuan yang sesuai dengan konteks zaman milenial.

Selanjutnya bab empat masuk kepada sebagian besar hasil penelitian, yakni praktik literasi. Bab ini membahas sikap mahasiswa terhadap membaca dan menulis, perilaku membaca dan menulis, serta memetakan tiga kelompok mahasiswa yang akrab dengan praktik literasi. Pembahasan perilaku menulis mencakup pembahasan tentang tujuan membaca: antara untuk belajar dan membaca untuk 
kesenangan, membaca genre fiksi lebih disukai mahasiswa, membaca literatur non fiksi, perilaku literasi menulis, perilaku tidak literat yang ditunjukkan denganp erilaku Plagiat atau "Copy-Paste"

Terakhir, bab lima merupakan penutup. Bab ini berisi simpulan dan saran. Simpulan merupakan jawaban atas rumusan masalah yang diajukan. Adapun saran adalah rekomendasi yang diajukan berdasarkan temuan penelitian. 


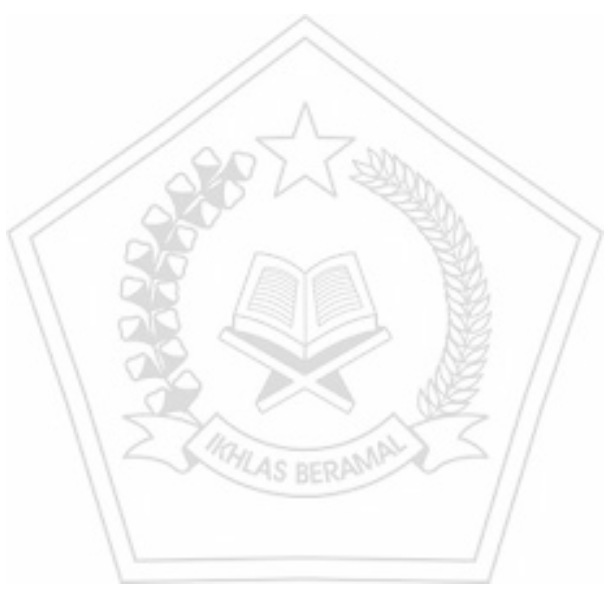




\section{BAB II. \\ Ruang dan Waktu Literasi: latar penelitian}

Kampus Universitas Islam Negeri (UIN) di beberapa daerah menjadi latar ruang praktik literasi. "Ruang kampus" sebagai latar praktik literasi mahasiswa terhubung dengan konteks akademik dan kelembagaan kampus. Dengan demikian pertama kali yang perlu dijelaskan adalah konteks akademik di masing-masing kampus.

Setelah deskripsi ruang, hal yang juga perlu dijelaskan adalah soal waktu sebagai latar penelitian. "Waktu" di sini bukan dipahami sebagai waktu terjadinya suatu peristiwa atau penelitian, tetapi lebih berarti sebagai sebuah masa atau era yang dijalani oleh para partisipan penelitian. Telah diketahui bahwa para partisipan penelitian ini adalah para mahasiswa yang jelas memiliki batasan masa atau era tertentu yang memerlukan penjelasan, yakni yang disebut dengan era milenial. Karena itu berbagai penjelasan dan ciri tentang mahasiswa yang hidup di era milenial juga perlu disampaikan. Dengan penjelasan kedua konteks ini,-ruang dan waktu - mahasiswa diandaikan berada dalam ruang dan waktu dengan ciri tertentu. 


\section{Ruang: Kampus sebagai Sponsor Praktik Literasi}

Selain sebagai lokasi penelitian, UIN dapat dipandang sebagai "sponsor" praktik literasi. Istilah "sponsor literasi" digunakan oleh Deborah Brandt (2001: 19) ketika meneliti praktik literasi dalam kehidupan orang-orang Amerika. Menurutnya, sponsor literasi adalah agen-baik konkret atau abstrak, lokal maupun non-lokal —yang memungkinkan untuk mendukung, mengajarkan, sebagai model, serta mengatur praktik literasi.

Lebih lanjut, sponsor literasi biasanya merupakan institusi besar yang berkuasa, saudara yang lebih tua, guru, dosen, pemimpin atau tokoh agama, militer, pustakawan, teman, editor, dan penulis yang berpengaruh. Para sponsor ini juga adalah tokoh-tokoh kuat yang dapat menyokong berbagai peristiwa atau memperlancar jalan bagi orang yang melakukan literasi. Biasanya lebih kaya, lebih berpengetahuan, dan atau lebih berkuasa daripada yang disponsori. Namun demikian, sponsor tetap memiliki hubungan timbal-balik dengan orangorang yang mereka tanggung. Mereka meminjamkan sumber daya atau kredibilitas mereka kepada yang disponsori tetapi juga mendapatkan manfaat dari kesuksesan mereka, baik secara langsung maupun tidak langsung (Brandt, 2001: 19).

Meskipun demikian, bukan berarti tidak terdapat sponsorsponsor lainnya yang mendukung literasi mahasiswa. Mahasiswa-mahasiswa tentu memiliki beberapa sponsor literasi dalam sepanjang hidupnya, baik sebelum belajar di kampus maupun ketika belajar di kampus. Karena itu keterhubungan antara ruang dan sponsor menjadi niscaya.

Selain itu, sponsor literasi juga memiliki pandanganpandangan tertentu yang menjadi ciri tertentu bagi agen sponsor tersebut, sehingga dapat mengarahkan orang-orang 
atau lembaga-lembaga yang disponsori. Untuk konteks lembaga pendidikan, tentu saja yang penting dicermati adalah pandangan-pandangan atau paradigma keilmuan lembaga pendidikan yang menjadi acuan bagi praktik literasi di kampus. Uraian tentang konteks ruang sebagai sponsor berikut juga akan berisi tentang konteks paradigma keilmuan baik secara umum maupun di masing-masing kampus.

\section{Dari IAIN menjadi UIN}

Universitas Islam Negeri (UIN) yang sekarang ini ada adalah perkembangan dari lembaga yang disebut dengan Institut Agama Islam Negeri (IAIN). UIN adalah sebuah lembaga pendidikan tinggi keagamaan Islam negeri yang berada di bawah Kementerian Agama. Ada beberapa hal yang perlu ditelisik mengenai perubahan IAIN menjadi UIN secara nasional, mulai dari Perguruan Tinggi Agama Islam, Institut Agama Islam Negeri hingga menjadi Universitas Islam Negeri. Uraian transformasi ini penting sebagai latar belakang penjelasan konteks di masing-masing kampus.

IAIN didirikan pada tahun 1970 yang diantara tujuannya adalah untuk menjadi pendidikan tinggi bagi lulusan pesantren dan madrasah. IAIN lahir diprakarsai oleh dua lembaga: yang satu berfokus pada pelatihan guru-guru Islam untuk sekolah-sekolah pemerintah yang disebut dengan Perguruan Tinggi Agama Islam Negeri (PTAIN); dan kedua dirancang untuk melatih para fungsionaris pegawai pemerintah di Kementerian Agama (dahulu Departemen Agama/Depag), yang disebut Akademi Dinas Ilmu Agama/ADIA (Akademi Ilmu Agama Pegawai). Oleh karena itu, tidak mengherankan jika fakultas terbesar di IAIN, di semua kampus, adalah Syariah (hukum Islam) dan Tarbiyah (pendidikan). Dua 
fakultas ini menyediakan tenaga hakim, guru, dan pejabat untuk birokrasi agama dan sistem pendidikan agama di Indonesia (Lukens-Bull, 2013: 12).

PTAIN mulai berdiri di Yogyakarta pada tahun 1950. Pendirian PTAIN di Yogyakarta dilakukan dengan mengubah status Fakultas Agama yang bernaung di bawah Universitas Islam Indonesia (UII) Yogyakarta menjadi PTAIN melalui Peraturan Pemerintah Nomor: 34 Tahun 1950, tanggal 14 Agustus 1950. Adapun ADIA didirikan di Jakarta berdasarkan Penetapan Menteri Agama No. 1 Tahun 1957 tanggal 1 Januari 1957. Institut Agama Islam Negeri (IAIN) sesungguhnya lahir dari peleburan dan penggabungan antara PTAIN di Yogyakarta dengan ADIA di Jakarta berdasarkan Peraturan Presiden Nomor 11 tahun 1960, tanggal 9 Mei 1960 yang disebut juga dengan Al-Jami'ah Al-Islamiyah Al-Hukumiyah Sunan Kalijaga Yogyakarta. Peleburan PTAIN dan ADIA menjadi IAIN didasarkan atas berbagai pertimbangan, antara lain: (1) keluasan dan kedalaman ruang lingkup ilmu pengetahuan agama Islam tidak memungkinkan untuk ditampung, dikaji, dan dikembangkan dalam satu wadah fakultas saja; (2) semakin meningkatnya dan majemuknya kebutuhan serta tuntutan masyarakat dan pemerintah terhadap penyediaan tempat dan fasilitas belajar dalam lingkungan PTAI di satu pihak dan terbatasnya kesempatan yang dapat diberikan oleh PTAIN dan ADIA di pihak lain; (3) semakin bertambahnya jumlah tenaga ahli dalam bidang agama Islam yang dibutuhkan oleh masyarakat dan pemerintah, sejalan pesatnya kehidupan berbangsa dan bernegara. Dimulai dari Yogyakarta dan Jakarta, mulai berdiri fakultas-fakultas di beberapa daerah hingga kemudian berdiri beberapa IAIN yang tersebar di beberapa wilayah Indonesia setelah tahun 
1963, seperti Yogyakarta, Jakarta, Banda Aceh, Palembang, Banjarmasin, Surabaya, Ujungpandang, Jambi, Padang, Bandung, Tanjungkarang, Semarang, Pekanbaru dan Medan (Lukens-Bull, 2013: 13-16).

Meskipun semua IAIN memiliki kemiripan, perbedaan tetap ada, yakni misalya pada jumlah fakultas. Pada umumnya IAIN memiliki lima fakultas, yaitu: Fakultas Adab, Dakwah, Syariah, Tarbiyah dan Ushuluddin, namun ada juga IAIN yang memiliki hanya empat fakultas. Perbedaan ini terjadi karena perbedaan latar belakang animo peminat, ketersediaan sumber daya manusia (SDM), serta kebutuhan di wilayah setempat.

Dimulai pada akhir 1990-an dan awal 2000-an, beberapa IAIN berubah dari institut ke universitas dengan menambahkan setidaknya dua fakultas non-keagamaan. Motivasi perubahan ini adalah soal kekhawatiran tentang kelayakan kerja siswa dan ingin memastikan bahwa komunitas Muslim tidak terpinggirkan secara ekonomi. Penambahan ini dimulai dengan apa yang disebut dengan "mandat yang diperluas" (with wider mandate), hingga penuh menjadi universitas. Perubahan IAIN menjadi UIN juga menimbulkan beberapa kekhawatiran, ada yang khawatir akan menjadi marjinalnya fakultas-fakultas agama atau kajian-kajian Islam yang sebetulnya inti dari Perguruan Tinggi Agama Islam. Selain itu, ada yang mengkhawatirkan tentang kualitas program non-keagamaan, sehingga menyimpulkan UIN bukan tempat terbaik untuk mempelajari ilmu-ilmu non-keagamaan (Lukens-Bull, 2013: 16-17). Penambahan fakultas nonkeagamaan juga memicu beberapa perdebatan tentang pengawasan fakultas tersebut di PTAIN, apakah melalui Kementerian Pendidikan atau tetap di dalam pengawasan 
Kementerian Agama. Meskipun ada sejumlah kekhawatiran dan perdebatan, beberapa UIN tetap berjalan bahkan mulai bermunculan di beberapa daerah baru-baru ini, seperti UIN Mataram dan UIN Banjarmasin.

Dipicu untuk membangun peradaban ilmu pengetahuan di tengah masyarakat Muslim melalui universitas, maka beberapa kampus mengajukan rancang bangun filosofis keilmuan sebagai "justifikasi ilmiah" perlunya sebuah lembaga universitas. Landasan filosofis ini kemudian menjadi dasar bagi kebijakan pengembangan akademis dan kelembagaan. Landasan filosofis ini ada yang merujuk pada figur penting di masing-masing kampus, tetapi ada yang memang didiskusikan secara bersama-sama oleh civitas akademika kampus, yang biasanya ditentukan oleh rektor dan jajarannya. Ulasan mengenai hal ini akan dijelaskan pada bagian selanjutnya di masing-masing pembahasan tentang kampus.

\section{UIN Sunan Kalijaga Yogyakarta}

Transformasi IAIN menjadi UIN Sunan Kalijaga Yogyakarta secara formal terjadi pada tahun 2004 (Faiz, 2007: v). Meskipun demikian, persiapan-persiapan baik dari sisi pemikiran keilmuan maupun peningkatan kapasitas kelembagaan telah dilakukan sejak tahun 1997/1998 (Abdullah, 2007: 2). Dengan dipelopori M. Amin Abdullah selaku rektor pada masa itu, paradigma kelimuan UIN diluncurkan, yakni paradigma keilmuan integrasiinterkoneksi ilmu dengan model "jaring laba-laba keilmuan" berwatak teoantroposentris-integralistik.

Inti gagasan jaring laba-laba keilmuan ini adalah pertama, struktur keilmuan membedakan tingkat abstraksi ilmu, mulai 
dari pure sciences hingga applied sciences yang satu sama lain saling terkait erat. Kedua, tidak ada pemisahan antara ilmu-ilmu Islam dengan ilmu-ilmu sekuler, sebab keduanya telah menyatu. Menurut Parluhutan Siregar (2014: 344), pada awalnya konsep jaring laba-laba (spider web) adalah suatu bentuk strategi pembelajaran yang sengaja dirancang untuk memudahkan transfer pengetahuan dan pengalaman kepada peserta didik. Metode jaring laba-laba ini menawarkan suatu strategi pembelajaran yang mengintegrasikan suatu tema ke dalam semua mata pelajaran. Metode jaring laba-laba juga menawarkan sebuah peta konsep yang saling berhubungan. Dengan demikian jaring laba-laba integrasi-interkoneksi keilmuan ini dipahami bahwa setiap bidang keilmuan memiliki keterkaitan satu sama lain.

Menurut M. Amin Abdullah (2007: 33) proyek integrasi kelimuan umum dan agama mengandung arti perlunya dialog dan kerjasama antara disiplin ilmu umum dan agama yang lebih erat di masa yang akan datang. Pendekatan interdisipliner dikedepankan, interkonkesitas dan sensitivitas antar berbagai disiplin ilmu perlu dibangun dan dikembangkan terus menerus. Semua itu dilakukan karena tuntutan zaman. Selain mempertimbangkan konsep keilmuan dengan model jaring laba-laba kelimuan yang integral, penyusunan ulang kurikulum dan mata kuliah harus juga mempertimbangkan tiga hal, yakni peradaban teks (hadarat al-nas), peradaban ilmu (hadarat 'ilm) dan peradaban filsafat (hadarat al-falsafah). Peradaban teks (bayani) tidak bisa lagi terlepas dari peradaban ilmu (sains, teknik dan komunikasi) dan dari peradaban filsafat (etik), serta begitu sebaliknya. Peradaban ilmu yang menghasilkan sains dan teknologi akan kehilangan karakter yang berpihak pada kehidupan manusia 
dan lingkungan hidup, jika mengabaikan peradaban filsafatetika dan peradaban teks. Sementara peradaban teks bersamasama dengan peradaban ilmu minus peradaban filsafat akan melahirkan pandangan radikalisme dan fundamentalisme (Abdullah, 2007: 36).

Beranjak dari filsafat keilmuan seperti itu, UIN Sunan Kalijaga tumbuh menjadi universitas dengan beragam program studi baik yang berbasis ilmu-ilmu pengetahuan empiris (sains dan sosial-humaniora) maupun yang berbasis ilmu-ilmu agama. Sekarang ini, UIN Sunan Kalijaga memiliki sembilan fakultas untuk jenjang sarjana (S1) dan satu program pascasarjana. Fakultas-fakultas tersebut adalah Fakultas Adab dan Ilmu Budaya, Fakultas Dakwah dan Komunikasi, Fakultas Ilmu Tarbiyah dan Keguruan, Fakultas Syariah dan Hukum, Fakultas Ushuluddin dan Pemikiran Islam, Fakultas Sains dan Teknologi, Fakultas Ilmu Sosial dan Humaniora dan Fakultas Ekonomi dan Bisnis Islam. Masing-masing fakultas ini memiliki sejumlah jurusan atau program studi, baik yang berbasis studi-studi agama maupun yang umum.

\section{UIN Maulana Malik Ibrahim Malang}

Universitas Islam Negeri (UIN) Maulana Malik Ibrahim Malang (selanjutnya UIN Malang) berdiri pada 2004 (Sahlan, 2012: 65). Sempat bernama Universitas Islam Indonesia-Sudan (UIIS) sebagai implementasi kerjasama antara pemerintah Indonesia dan Sudan dengan tujuan mengembangkan ilmu pengetahuan yang bersumber pada penalaran logis seperti observasi dan eksperimentasi, serta bersumber pada Alquran dan hadis. Ini kemudian disebut dengan paradigma integrasi ilmu yang berpusat pada Alquran dan hadis (Sahlan, 2012: 67). 
Model integrasi yang dibangun dan menjadi blue print pengembangan UIN Malang dikenal dengan "pohon ilmu" yang dicetuskan oleh Imam Suprayogo, tokoh yang memang sangat berperan dalam transformasi UIN Malang. Pohon ilmu adalah sebuah metafora bangunan akademik yang terdiri dari tanah, akar, batang, dahan, ranting dan daun serta buah. Tanah adalah tempat tumbuh dan berkembangnya pohon. Ia mengandaikan lingkungan yang harus dijaga demi kesuburan pohon. Sementara akar adalah "ilmu-ilmu alat" seperti bahasa, filsafat, Pancasila, Ilmu Alamiah Dasar dan Ilmu Sosial Dasar. Adapun batang adalah ilmu-ilmu yang bersumber pada Alquran dan Sunnah yang mencakup ilmu Alquran, ilmu hadis, sirah nabawiyah, dan pemikiran Islam (fikih, kalam dan tasawuf). Sedangkan dahan adalah pilihan-pilihan fakultas sesuai dengan minat-minat masingmasing individu. Akhirnya buah adalah metafora bagi hasil integrasi ilmu dan agama yang berupa ilmu, amal saleh, dan akhlakul karimah. Jika akar dan batang merupakan fardu 'ain (wajib dimiliki dan ada) dalam seluruh proses pendidikan di perguruan tinggi pada masing-masing individu, maka dahan, ranting dan daun merupakan fardu kifayah (tidak wajib seluruhnya) bagi masing-masing individu dalam proses pendidikan di perguruan tinggi. Perpaduan antara akar, batang, dahan, ranting dan pohon akan menghasilkan buah ilmu pengetahuan yang bermanfaat bagi kemanusiaan (Pedoman Pendidikan UIN Maulana Malik Ibrahim Malang, 2017).

Ciri khusus lain dari universitas ini sebagai implikasi dari model pengembangan keilmuan dengan metafora pohon ilmu adalah adanya keharusan bagi seluruh anggota sivitas akademika untuk menguasai bahasa Arab dan bahasa Inggris. 
Karena bahasa, dalam metafora pohon ilmu tersebut, adalah alat pengembangan keilmuan yang harus dimiliki oleh seseorang. Melalui bahasa Arab, diharapkan mereka mampu melakukan kajian Islam melalui sumber aslinya, yaitu Alquran dan Hadis, dan melalui bahasa Inggris mereka diharapkan mampu mengkaji ilmu-ilmu umum dan modern, selain juga dapat menjadi alat komunikasi di dunia global saat ini. Karena itu pula, universitas ini disebut bilingual university. Untuk mencapai maksud tersebut, dikembangkan ma'had atau pesantren kampus di mana seluruh mahasiswa tahun pertama harus tinggal di ma'had. Karena itu, pendidikan di universitas ini merupakan sintesis antara tradisi universitas dan ma'had atau pesantren (Pedoman Pendidikan UIN Maulana Malik Ibrahim Malang, 2017).

Dengan landasan keilmuan seperti itu, UIN Malang memiliki enam fakultas dan satu Program Pascasarjana, yaitu: (1) Fakultas Ilmu Tarbiyah dan Keguruan, menyelenggarakan Jurusan Pendidikan Agama Islam (PAI), Jurusan Pendidikan Ilmu Pengetahuan Sosial (IPS), dan Jurusan Pendidikan Guru Madrasah Ibtidaiyah (PGMI), (2) Fakultas Syariah, menyelenggarakan Jurusan al-Ahwal al-Syakhshiyyah dan Hukum Bisnis Syariah (3) Fakultas Humaniora, menyelenggarakan Jurusan Bahasa dan Sastra Arab, dan Jurusan Bahasa dan Sastra Inggris, dan Jurusan Pendidikan Bahasa Arab (4) Fakultas Ekonomi, menyelenggarakan Jurusan Manajemen, Akuntansi, Diploma III Perbankan Syariah, dan S-1 Perbankan Syariah (5) Fakultas Psikologi, dan (6) Fakultas Sains dan Teknologi, menyelenggarakan Jurusan Matematika, Biologi, Fisika, Kimia, Teknik Informatika, Teknik Arsitektur dan Farmasi. Adapun Program Pascasarjana mengembangkan 6 (enam) program 
studi magister, yaitu: (1) Program Magister Manajemen Pendidikan Islam, (2) Program Magister Pendidikan Bahasa Arab, (3) Program Magister Agama Islam, (4) Program Magister Pendidikan Guru Madrasah Ibtidaiyah (PGMI), (5) Program Magister Pendidikan Agama Islam, dan (6) Program Magister al-Ahwal al-Syakhshiyyah. Sedangkan untuk program doktor dikembangkan 2 (dua) program yaitu (1) Program Doktor Manajemen Pendidikan Islam dan (2) Program Doktor Pendidikan Bahasa Arab (Pedoman Pendidikan UIN Maulana Malik Ibarahim Malang, 2017).

\section{UIN Walisongo Semarang}

UIN Walisongo, sebelumnya IAIN Walisongo, keberadaannya tidak bisa dilepaskan dari Fakultas Tarbiyah Kudus yang dibimbing oleh IAIN Sunan Kalijaga Yogyakarta yang berada sejak tahun 1966 (Panduan Program Sarjana (S.1 dan Diploma (D.3), tahun akademik 2017/2018: 8). Namun, secara resmi IAIN Walisongo berdiri pada 1970. Sejak menjadi negeri, IAIN Walisongo mengalami perkembangan dan perubahan, baik pada struktur kelembagaan (institusi) maupun komposisi fakultasnya.

Setelah menjadi negeri, IAIN Walisongo membawahi lima fakultas. Fakultas Dakwah di Semarang sebagai fakultas induk, Fakultas Syariah di Bumiayu, Fakultas Ushuluddin di Kudus, dan Fakultas Tarbiyah di Salatiga. Lalu sejak tahun 1973 dan 1974, beberapa fakultas cabang IAIN Walisongo menjadi fakultas induk yang berkedudukan di Semarang, yakni Fakultas Dakwah di Semarang, Fakultas Syariah di Semarang, Fakultas Tarbiyah di Semarang, Fakultas Ushuluddin di Semarang. Secara yuridis keberadaan IAIN Walisongo menjadi lebih mantap setelah terbit Peraturan 
Pemerintah Nomor 33 Tahun 1985 tentang Pokok-pokok Organisasi IAIN dan Keputusan Presiden Nomor 9 tahun 1987 tentang susunan organisasi IAIN. Beberapa peraturan ini semakin memperjelas posisi IAIN Walisongo dengan fakultas-fakultasnya (Panduan Program Sarjana (S.1 dan Diploma (D.3), tahun akademik 2017/2018: 30). Sejak tahun 2014, IAIN Walisongo bertransformasi menjadi UIN Walisongo.

Transformasi menjadi UIN Walisongo kemudian diikuti dengan dibuka beberapa fakultas baru dan dibuatnya nomenklatur baru pada fakultas-fakultas yang ada. Fakultasfakultas baru itu adalah Fakultas Ilmu Sosial dan Politik, Fakultas Psikologi dan Kesehatan, dan Fakultas Sains dan Teknologi. Adapun fakultas lama dengan nomenklatur baru adalah Fakultas Syariah dan Hukum, Fakultas Ushuluddin dan Humaniora, Fakultas Tarbiyah dan Keguruan, Fakultas Dakwah dan Komunikasi dan Fakultas Ekonomi dan Bisnis Islam. Fakultas Syariah dan Hukum memiliki empat jurusan/ program studi, Fakultas Ushuluddin dan Humaniora memiliki empat jurusan, Fakultas Ilmu Tarbiyah dan Keguruan memiliki tujuh fakultas, Fakultas Dakwah dan Komunikasi memiliki empat jurusan, Fakultas Ekonomi dan Bisnis Islam memiliki empat jurusan, Fakultas Ilmu Sosial dan Politik memiliki dua jurusan, Fakultas Psikologi dan Kesehatan memiliki dua jurusan, Fakultas Sains dan Teknologi memiliki delapan jurusan (Panduan Program Sarjana (S.1 dan Diploma (D.3), tahun akademik 2017/2018: 37).

Pengembangan akademik yang dilakukan oleh UIN Walisongo juga merupakan pengembangan yang didasari oleh sebuah landasan filosofis pengembangan paradigma keilmuan. Bangunan integrasi ilmu yang dikembangkan UIN Walisongo 
adalah paradigma wahdat al-'ulum (unity of sciences). Paradigma ini menegaskan bahwa semua ilmu bersumber dari Allah sebagai al-'Alim (Yang Maha Mengetahui). Oleh karena itu sudah semestinya saling berdialog dan bermuara pada satu tujuan, yakni mengantarkan pengkajinya semakin mengenal dan semakin dekat kepada Allah (Institut Agama Islam Negeri Walisongo, 2013: 12).

Paradigma wahdatul ulum disimbolisasikan dengan sebuah intan berlian yang sangat indah dan bernilai tinggi, memancarkan sinar, memiliki sumbu dan sisi yang saling berhubungan satu sama lain. Sumbu paling tengah menggambarkan Allah sebagai sumber nilai, doktrin dan ilmu pengetahuan. Allah menurunkan ayat-ayat Quraniyah dan kauniyah sebagai lapangan eksplorasi pengetahuan yang saling melengkapi dan tidak mungkin saling bertentangan. Eksplorasi atas ayat-ayat Allah menghasilkan lima gugus ilmu, yaitu: ilmu agama dan humaniora, yakni ilmu-ilmu yang muncul saat manusia belajar tentang agama dan diri sendiri, seperti ilmu-ilmu keislaman, seni, sejarah, bahasa dan filsafat; ilmu-ilmu sosial, yaitu ilmu yang muncul saat belajar interaksi antar sesamanya, seperti sosiologi, ekonomi, geografi, politik dan psikologi; ilmu-ilmu kealaman, yaitu ilmu yang muncul saat manusia belajar tentang fenomena alam, seperti kimia, fisika, antariksa dan geologi; ilmu matematika dan sains komputer, yaitu ilmu yang muncul saat manusia mengkuantisasi gejala sosial dan alam, seperti komputer, logika, matematika dan statistik; ilmu-ilmu profesi dan terapan, yaitu ilmu-ilmu yang muncul saat manusia menggunakan kombinasi dua dan atau lebih keilmuan di atas untuk memecahkan problem yang dihadapinya, seperti pertanian, arsitektur, bisnis, hukum, manajemen dan 
pendidikan (Institut Agama Islam Negeri Walisongo, 2013: 13). Semua ilmu-ilmu tersebut sesungguhnya dimaksudkan agar lulusan mampu menjawab tantangan zaman baik di bidang agama, kemanusian dan alam.

\section{UIN Sunan Ampel Surabaya}

Tahun 1965 IAIN Sunan Ampel berdiri di Surabaya. Dalam rentang waktu antara 1966-1970, IAIN Sunan Ampel telah memiliki 18 (delapan belas) fakultas yang tersebar di 3 (tiga) propinsi: Jawa Timur, Kalimantan Timur dan Nusa Tenggara Barat. Namun demikian, ketika akreditasi fakultas di lingkungan IAIN diterapkan, lima dari 18 (delapan belas) fakultas tersebut ditutup untuk digabungkan ke fakultas lain yang terakreditasi dan berdekatan lokasinya. Selanjutnya dengan adanya Peraturan Pemerintah Nomor 33 Tahun 1985, Fakultas Tarbiyah Samarinda dilepas dan diserahkan pengelolaannya ke IAIN Antasari Banjarmasin. Kemudian, Fakultas Tarbiyah Bojonegoro dipindahkan ke Surabaya dan statusnya berubah menjadi Fakultas Tarbiyah IAIN Surabaya. Dalam pertumbuhan selanjutnya, IAIN Sunan Ampel memiliki 12 (dua belas) fakultas yang tersebar di seluruh Jawa Timur dan 1 (satu) fakultas di Mataram, Lombok, Nusa Tenggara Barat (UIN Sunan Ampel Surabaya, 2017: 1-4).

Sejak pertengahan 1997, melalui Keputusan Presiden Nomor 11 Tahun 1997, seluruh fakultas yang berada di bawah naungan IAIN Sunan Ampel yang berada di luar Surabaya lepas dari IAIN Sunan Ampel menjadi Sekolah Tinggi Agama Islam Negeri (STAIN) yang otonom. IAIN Sunan Ampel sejak saat itu pula terkonsentrasi hanya pada 5 (lima) fakultas yang semuanya berlokasi di kampus di Surabaya. 
Terhitung mulai tanggal 1 Oktober 2013, IAIN Sunan Ampel berubah menjadi UIN Sunan Ampel Surabaya berdasarkan Keputusan Presiden RI Nomor 65 Tahun 2013. Sekarang ini, UIN Sunan Ampel Surabaya memiliki sembilan fakultas dan pasca sarjana, 33 program studi sarjana, delapan program studi magister dan tiga program doktor. Untuk jenjang sarjana (S.1) fakultas-fakultas yang ada yaitu: Fakultas Adab dan Humaniora dengan tiga program studi; Fakultas Dakwah dan Komunikasi dengan lima program studi; Fakultas Syariah dan Hukum dengan tiga program studi; Fakultas Tarbiyah dan Keguruan dengan tujuh program studi; Fakultas Ushuluddin dan Filsafat dengan empat program studi; Fakultas Ilmu Sosial dan Politik dengan tiga program studi; Fakultas Sains dan Teknologi dengan tujuh program studi; dan Fakultas Ekonomi dan Bisnis Islam dengan empat program studi.

Seperti UIN yang lain, UIN Sunan Ampel dalam mengembangkan akademik dan kelembagaannya juga bertumpu pada sebuah paradigma keilmuan. UIN Sunan Ampel mengembangkan paradigma keilmuannya dengan model menara kembar tersambung (integrated twin-towers). Model ini berpandangan bahwa ilmu-ilmu keislaman, sosialhumaniora, serta sains dan teknologi berkembang sesuai dengan karakter dan obyek spesifik yang dimiliki masingmasing ilmu. Namun, kendati ilmu-ilmu tersebut berkembang masing-masing, ilmu-ilmu tersebut dapat saling menyapa, bertemu dan mengaitkan diri satu sama lain dalam suatu pertumbuhan yang terkoneksi. Tidak seperti model integrasi keilmuan di UIN Yogyakarta, Malang, dan Semarang, model integrasi keilmuan UIN Sunan Ampel tidak terjebak atau bergerak pada islamisasi ilmu pengetahuan, tetapi islamisasi nalar yang dibutuhkan untuk tercipta tata keilmuan yang saling 
melengkapi antar ilmu-ilmu keislaman, sosial-humaniora serta sains dan teknologi (http://www.uinsby.ac.id/id/251/ paradigma-keilmuan.html).

\section{UIN Mataram}

UIN Mataram diresmikan berdasarkan Peraturan Presiden Republik Indonesia Nomor 34 Tahun 2017 pada Tanggal 3 April 2017. Sebelum menjadi UIN, lembaga ini bernama IAIN Mataram berdasarkan Keputusan Presiden Republik Indonesia Nomor 91 Tahun 2004 tentang Alih Status STAIN Mataram menjadi IAIN Mataram. STAIN Mataram sendiri berdiri tahun 1997 berdasarkan Keputusan Presiden RI Nomor 11 Tahun 1997 tentang Pendirian Sekolah Tinggi Agama Islam Negeri. Sebelum menjadi STAIN, lembaga ini merupakan Fakultas Tarbiyah dan Fakultas Syariah cabang UIN Sunan Ampel yang telah berada di Mataram sejak tahun 1966.

UIN Mataram menjadi satu-satunya lembaga Pendidikan Tinggi Agama Islam Negeri di kawasan tenggara Indonesia yang berada di ibu kota Provinsi Nusa Tenggara Barat. Dari sisi geografis, UIN Mataram berada di antara Provinsi Nusa Tenggara Timur (NTT) dengan masyarakat mayoritas Nasrani dan Provinsi Bali dengan masyarakat mayoritas Hindu, dan Provinsi Nusa Tenggara Barat sendiri yang masyarakatnya mayoritas beragama Islam (Pedoman Akademik UIN Mataram, 2017: 4). Karena itu, UIN Mataram memiliki tantangan dan peran sebagai agen keharmonisan umat beragama dengan menyelenggarakan pendidikan yang integratif antara keilmuan Islam dan ilmu-ilmu lainnya.

Saat ini, dengan berubahnya menjadi Universitas, UIN Mataram memiliki lima fakultas dengan 23 jurusan 
atau program studi di masing-masing fakultas (Pedoman Akademik UIN Mataram, 2017: 26). Jurusan yang paling banyak adalah Fakultas Tarbiyah dan Keguruan, lalu berturutturut Fakultas Dakwah dan Ilmu Komunukasi, Fakultas Syariah, Fakultas Ekonomi dan Bisnis Islam serta Fakultas Ushuluddin dan Studi Agama. Mahasiswa terbanyak pun dari Fakultas Tarbiyah dan Keguruan. Hal ini dapat dipahami karena Fakultas Tarbiyah dan Keguruan adalah cikal bakal STAIN, IAIN lalu UIN. Jurusan-jurusan di Fakultas Tarbiyah dan Keguruan menjadi jurusan-jurusan yang banyak diminati oleh mahasiswa.

Kebanyakan input mahasiswa berasal dari pelosokpelosok di Nusa Tenggara Barat dan Nusa Tenggara Timur, serta beberapa daerah di Bali. Mahasiswa-mahasiswa ini berasal dari kelas menengah ke bawah. Hal ini dapat dipahami karena biasanya anak-anak yang berasal dari kelas menengah ke atas lebih memilih untuk melanjutkan belajar ke beberapa perguruan tinggi ternama di Pulau Jawa, seperti Jawa Timur (Malang dan Surabaya), Yogyakarta dan Jakarta. Mahasiswamahasiswa yang memilih jurusan agama biasanya adalah mahasiswa lulusan Madrasah Aliyah (MA), sedangkan mahasiswa-mahasiswa yang memilih jurusan umum biasanya berasal dari Sekolah Menengah Atas (SMA) (Wawancara dengan Wakil Rektor Bidang Kemahasiswaan UIN Mataram, 21 Mei 2018).

Pembukaan jurusan-jurusan yang bukan bidang kajian Islam, seperti pendidikan matematika, pendidikan ilmu pengetahuan alam dan sosiologi adalah suatu konsekuensi dari pengembangan lembaga menjadi universitas. Sebagai pusat pengembangan dan penyebaran keilmuan, teknologi, dan kebudayaan, UIN Mataram mengajukan model "horizon 
ilmu." Horizon ilmu (afaqul ilmi) merupakan rancang bangun keilmuan yang bersumber pada Alquran dan Hadis. Dua sumber utama umat Islam ini ditempatkan sebagai pusat atau sentral keseluruhan disiplin keilmuan yang sedang digeluti dan akan terus dikembangkan oleh UIN Mataram. Proses pengembangan ilmu dilakukan dengan memadukan berbagai pendekatan keilmuan untuk dapat menghasilkan insan cendekiawan yang paripurna (insan kamil). Oleh karena itu, epistemologi yang dikembangkan memadukan antara epistemologi bayani, burhani, 'irfani (Taufik, 2013: 1-16).

Melalui tiga epistemologi tersebut, diharapkan terjadi tiga dimensi pengetahuan yang meliputi hakekat, subjek dan objek pengetahuan. Pertama, terkait dengan hakekat pengetahuan, terjadi perubahan dari pengetahuan diskursifrasional ke pengetahuan spiritual. Kedua, terkait dengan subyek pengetahuan, terjadi perubahan dari rasio ke hati. Ketiga, terkait dengan obyek pengetahuan, terjadi perubahan dari diskrit dan formal ke prinsip-prinsip esensial realitas (Taufik, 2013: 9).

Bertolak dari sumber utama Alquran dan Hadis dengan tiga epistemologi, berbagai disiplin ilmu terus dikembangkan dengan memperhatikan dua hal pokok, yaitu perkembangan keilmuan kontemporer dan keberadaan fakultas-fakultas yang ada, kemudian akan dikembangkan oleh UIN Mataram. Sejumlah disiplin ilmu itu misalnya Pendidikan Islam, Hukum dan Pranata, Dakwah dan Komunikasi, Sejarah Peradaban, Bahasa dan Sastra, Sains dan Teknologi, Sosial Humaniora. Semua disiplin keilmuan ini dikembangkan secara integratif (Pedoman Akademik UIN Mataram, 2017: 11-12).

Kegiatan pendidikan UIN Mataram mengacu pada sejumah prinsip sebagai berikut: 
1. Pendidikan untuk semua (education for all). Pendidikan merupakan hak dasar setiap warga masyarakat yang harus didukung, diperjuangkan dan dilaksanakan. Setiap warga masyarakat harus memiliki akses yang luas untuk mendapatkan layanan pendidikan yang berkualitas;

2. Pendidikan harus mencerahkan dan memberdayakan (enlighting and empowering) untuk masa depan yang lebih baik. Pengembangan peserta didik diarahkan menuju kedewasaan, kemerdekaan dan kemandirian berpikir, bertindak dan merencanakan masa depan. Implementasi prinsip ini mencakup penerapan model pembelajaran yang menyenangkan untuk semua disiplin ilmu, serta kurikulum mengajarkan ilmu yang "bermanfaat" di masa kini dan masa depan;

3. Pendidikan dengan pendekatan multi aspek (multiaspects approach). Untuk bekal masa depan, semua potensi peserta didik dikembangkan yang meliputi pengembangan pengetahuan dan intelektualitas, keterampilan life skill, kebugaran fisik, kepribadian, akhlak karimah dan spiritualitas, seni, kebudayaan, nasioanalisme, spirit kebersamaan dan harmoni social, dan kesadaran ekologis; dan

4. Pendidikan merupakan tanggung jawab semua (education is responsibility of all) yang mencakup negara, pemerintah, sekolah, keluarga, peserta didik dan warga masyarakat (Pedoman Akademik UIN Mataram, 2017: 13-14).

Proses pembelajaran di UIN Mataram menggunakan strategi active learning yang menempatkan dosen sebagai fasilitator dan mahasiswa sebagai subyek pembelajaran yang menuntut mahasiswa belajar secara kreatif dan mandiri. 
Pembelajaran bukan hanya berlangsung di kelas saja, melainkan mengembangkan model-model pembelajaran di luar kelas dengan memanfaatkan seluruh sumber belajar yang ada di lingkungan sekitar, misalnya perpustakaan, laboratorium, museum, alam sekitar, dan masyarakat. UIN Mataram memiliki satu perpustakaan pusat (Pedoman Akademik UIN Mataram, 2017: 39). Beberapa fakultas memiliki perpustakaan, seperti Fakultas Tarbiyah dan Keguruan dan Fakultas Dakwah dan Ilmu Komunikasi.

Kurikulum yang berlaku di UIN Mataram adalah Kurikulum Berbasis Kompetensi (KBK) integrasiinterkoneksi dan KKNI dengan tujuan agar lulusannya memiliki kompetensi yang sesuai dengan sasaran jurusan/ program studi dan mampu mengintegrasikan studi keislaman dan keilmuan. Kurikulum yang berlaku adalah sesuai tahun akademik berjalan. Mata kuliah yang ada terdiri dari mata kuliah jurusan, mata kuliah fakultas dan mata kuliah institut. Setiap mata kuliah memiliki penugasan, baik tertulis maupun tidak (Pedoman Akademik UIN Mataram, 2017: 54).

\section{UIN Antasari Banjarmasin}

UIN Antasari Banjarmasin adalah UIN yang paling baru dibanding dengan beberapa UIN yang telah dideskripsikan. Berdiri pada 3 April 2017, kampus ini pun berawal dari IAIN. IAIN Antasari Banjarmasin sendiri berdiri pada 1964. IAIN Antasari Banjarmasin berdiri berawal dari Fakultas Syariah. Sejak berdiri hingga tahun 1970, IAIN Antasari telah berkembang menjadi sembilan fakultas. Proses pengintegrasian dan pemindahan fakultas-fakultas di berbagai daerah di Kalimantan Selatan berakhir pada tahun 1980. Sehingga mulai tahun 1980, IAIN Antasari hanya mempunyai 
empat fakultas yang semuanya ada di Banjarmasin, yaitu: Fakultas Syariah, Fakultas Tarbiyah, Fakultas Dakwah, dan Fakultas Ushuluddin. Tahun 1988 fakultas yang ada di IAIN Antasari bertambah menjadi enam, yaitu dengan di integrasikasikannya Fakultas Tarbiyah Palangka Raya dan Fakultas Tarbiyah Samarinda sebagai Cabang dari IAIN Antasari (http://www.uin-antasari.ac.id/sejarah/\#).

Perkembangan selanjutnya pada tahun 1999, Fakultas Tarbiyah Palangka Raya berubah menjadi STAIN Palangka Raya dan Fakultas Tarbiyah Samarinda menjadi STAIN Samarinda, sehingga IAIN Antasari kembali menjadi empat fakultas, yaitu: Fakults Syariah, Fakultas Tarbiyah, Fakultas Dakwah Fakultas Ushuluddin (Pedoman Akademik IAIN Antasari Banjarmasin, 2015).

Sejak menjadi UIN, kampus ini memiliki enam fakultas, yaitu: Fakultas Tarbiyah dan Keguruan, Fakultas Syariah, Fakultas Dakwah dan Ilmu Komunikasi, Fakultas Ushuluddin dan Humaniora, Fakultas Ekonomi dan Bisnis Islam, serta Pascasarjana. Fakultas Tarbiyah dan Keguruan memiliki 13 program studi, Fakultas Syariah memiliki tiga program studi, Fakultas Dakwah dan Ilmu Komunikasi memiliki tiga program studi, Fakultas Ushuluddin dan Humaniora memiliki empat program studi, dan Fakultas Ekonomi dan Bisnis Islam memiliki empat program studi. Tampak penambahan beberapa program studi dalam ranah ilmu-ilmu umum menunukkan transformasi menjadi UIN.

Seperti beberapa UIN yang sudah lebih dahulu bertransformasi, UIN Antasari juga memiliki semangat integrasi keilmuan. Konsep integrasi keilmuan yang diusung memiliki beberapa ciri-ciri yang membedakan dengan integrasi-integrasi yang lain. Ciri-ciri tersebut adalah: (1) 
integrasi dinamis; (2) integrasi Islam dan kebangsaan; (3) berbasis lokal; (4) berwawasan global. Sesuai dengan gelar yang diberikan kepada Banjarmasin sebagai kota "seribu sungai," maka julukan tersebut juga dibunakan dalam metafor pengembangan keilmuan yang mencakup keempat ciri tersebut. Metafor yang digunakan oleh "sungai pengetahuan" (Yuliana Irawan, tanpa tahun: 2).

Sungai sebagai simbol Kota Banjarmasin. Sungai adalah urat nadi kehidupan masyarakat Banjar, yang selain dikonsumsi airnya, juga menjadi jalur transportasi, perdagangan, perairan, dan bermain. Sungai melambangkan integrasi ilmu karena air berasal dari langit, yaitu air hujan yang melambangkan wahyu Tuhan, sumber ilmu-ilmu keislaman. Ketika air hujan itu turun ke bumi, ia terintegrasi dengan seluruh partikel atau unsur-unsur yang ada di bumi. Hal ini melambangkan ilmu alam. Kemudian, aliran sungai juga dimanfaatkan oleh masyarakat dari berbagai latar belakang sosial-budaya yang melambangkan ilmu sosial dan humaniora. Dengan demikian, air hujan melambangkan ayat-ayat qauliyah, sedangkan bumi melambangkan ayatayat kauniyah. Keduanya berpadu dalam sungai. Integrasi sungai ini bersifat dinamis karena air sungai selalu bergerak dan mengalir dalam keterpaduan unsur-unsur yang ada di dalamnya (Irawan, tanpa tahun: 16).

SungaipunmelambangkanintegrasiIslamdankebangsaan. Air hujan yang turun ke sungai ibarat wahyu yang universal, kemudian turun ke bumi lalu masuk dalam ruang dan waktu aliran "sungai Indonesia." Inilah yang kemudian melahirkan "pribumisasi Islam," yakni Islam di bumi Indonesia. Islam hadir dalam kehidupan bangsa yang berbeda-beda, dengan warna yang berbeda-beda, meskipun sumber asalnya tetap 
sama. Perumpamaan sungai ini menunjukkan bahwa proses penyesuaian Islam konteks sosial-budaya Indonesia adalah suatu yang alamiah, meskipun tidak mengubah hakikat Islam, melainkan hanya membentuk varian-varian dalam kehidupan Islam Indonesia. Dengan begitu, sungai juga menjadi simbol lokalitas Indonesia, yang mengacu pada keragaman etnis dan budaya serta geografis. Namun, sungai juga menunjukkan dimensi globalitas. Artinya meskipun sungai bercabangcabang, tetapi pada akhirnya akan bermuara di samudera yang menyimbolkan globalitas dunia, karena samudera adalah wadah pertemuan berbagai sumber air, segala jenis makhluk hidup dari berbagai wilayah di dunia. Begitu juga, samudera adalah kawasan yang dilewati kapal-kapal besar dari berbagai bangsa, hingga menjadi tempat penghubung dan perjumpaan berbagai bangsa di dunia (Yuliana Irawan, tanpa tahun: 16-17).

\section{UIN dan Potensi Pengembangan Multiliterasi}

Pengembangan keilmuan di masing-masing UIN sebagaimana yang telah dijelaskan, menurut perspektif kajian literasi dapat dipandang sebagai sebuah upaya mengembangkan kemampuan multiliterasi untuk para mahasiswa. Masing-masing buku pedoman akademik UIN, seperti UIN Sunan Kalijaga, UIN Sunan Ampel Surabaya, dan UIN Mataram misalnya, menunjukkan bahwa kurikulum yang mereka gunakan mengacu pada Kerangka Kualifikasi Nasional Indonesia (KKNI) dan Standar Nasional Pendidikan Tinggi (SN-Dikti). Hal tersebut sarat dengan kemampuan multiliterasi.

Peraturan Presiden Nomor 8 Tahun 2012 dan UndangUndang Nomor 12 Tahun 2012 tentang Pendidikan Tinggi, 
menjelaskan bahwa KKNI adalah kerangka penjenjangan kualifikasi kompetensi yang dapat menyandingkan, menyetarakan dan mengintegrasikan antara bidang pendidikan dan bidang pelatihan kerja serta pengalaman kerja dalam rangka pemberian pengakuan kompetensi kerja sesuai dengan struktur pekerjaan di berbagai sektor. Menurut Peraturan Menteri Pendidikan dan Kebudayaan Nomor 73 Tahun 2013, yang dimaksud dengan KKNI bidang pendidikan tinggi adalah kerangka penjenjangan kualifikasi yang dapat menyandingkan, menyetarakan dan mengintegrasikan capaian pembelajaran di jalur pendidikan formal, pendidikan informal dan atau pengalaman kerja ke dalam jenis dan jenjang pendidikan tinggi. Capaian pembelajaran menurut KKNI, sebagaimana di dalam Peraturan Presiden Nomor 8 tahun 2012, adalah internalisasi dan akumulasi ilmu pengetahuan, pengetahuan, pengetahuan praktis, keterampilan, afeksi, dan kompetensi yang dicapai melalui proses pendidikan yang terstruktur dan mencakup suatu bidang ilmu atau keahlian tertentu atau melalui pengalaman kerja.

Berdasarkan Peraturan Menteri Ristek dan Dikti Nomor 44 Tahun 2015 tentang Standar Nasional Pendidikan Tinggi, rumusan capaian pembelajaran tercakup dalam salah satu standar, yaitu Standar Kompetensi Lulusan sebagaimana tercantum dalam pasal 5 ayat (1) sebagai berikut: "Standar Kompetensi Lulusan merupakan kriteria minimal tentang kualifikasi kemampuan lulusan yang mencakup sikap, pengetahuan, dan keterampilan yang dinyatakan dalam rumusan capaian pembelajaran lulusan." Kemudian, pasal 6 Peraturan Menteri tersebut memberikan uraian tentang empat unsur capaian pembelajaran yang terdiri dari: (1) sikap; (2) pengetahuan; (3) keterampilan umum; (4) keterampilan khusus. 
Meskipun kurikulum KKNI mengandaikan adanya satu keahlian yang harus dikuasai oleh mahasiswa, tetapi dengan basis integrasi keilmuan yang dikembangkan di masingmasing UIN, tentu saja yang diharapkan adalah kemampuan menyelesaikan permasalahan secara komprehensif dan multiperspektif. Hal ini menyiratkan adanya kesadaran multiliterasi, karena kehidupan modern mensyaratkan peningkatan kecakapan literasi manusia dalam definisinya yang jamak (multiliterate skills) (Dewayani, 2017: 16).

Multiliterasi adalah keadaan tentang keragaman literasi. Multiliterasi dirancang berdasarkan multi kompetensi. Memang, awalnya literasi dimaknai sebagai kemampuan mendapatkan informasi dalam simbol-simbol bahasa (teks). Sejalan dengan perkembangan zaman, istilah literasi berkembang menurut bidang ilmu masing-masing (Abidin, Mulyati dan Yunansah, 2017: 8). Bidang ilmu bahasa misalnya terfokus pada literasi membaca dan menulis, bidang ilmu teknologi informasi terfokus pada literasi teknologi informasi, bidang ilmu ekonomi terfokus pada literasi ekonomi dan finansial. Dalam bidang matematika muncul literasi numerik atau literasi matematis. Untuk bidang agama, muncul literasi agama. Dari sini jelas bahwa literasi digunakan dalam berbagai bidang ilmu dengan memanfaatkan media atau simbol-simbol bahasa sebagai alat komunikasi dan pembentukan makna dalam bidang-bidang ilmu tersebut.

McConachie (2010: 16-17) menggunakan istilah "literasi disipliner" untuk menggambarkan multiliterasi. Menurutnya, literasi disipliner adalah literasi yang menekankan penggunaan kemampuan membaca, logika, penelitian, berbicara, dan menulis untuk mempelajari dan membentuk pemahaman yang kompleks atas konten pengetahuan yang 
berhubungan dengan bidang keilmuan tertentu. Berdasarkan pendapat ini, menurut Abidin, Mulyati dan Yunansah (2017: 8-9) pembelajaran multiliterasi senantiasa menggunakan keterampilan-keterampilan berbahasa sebagai alat utama dalam melakukan kegiatan penelitian kritis, sekaligus sebagai sarana membangun pengetahuan. Hal tersebut senada dengan Ivanic (2009: 100-101) yang menyatakan bahwa, pembelajaran multiliterasi adalah pembelajaran yang memberikan tantangan kepada mahasiswa untuk mengkaji berbagai konsep dalam berbagai bidang.

Berdasarkan uraian di atas, multiliterasi terkandung semangat multidisiplin, interdisiplin dan integrasi sekaligus. Hal itu karena yang menjadi fokus adalah pada obyek permasalahan atau bidang keilmuan yang dihadapi dan dibutuhkan oleh masyarakat. Jika dicermati, berbagai paradigma yang menjadi dasar pengembangan UIN sebagaimana telah terurai itu menginginkan kemampuan multiliterasi di dalam diri mahasiswa, meskipun tetap memiliki satu kemampuan atau keahlian khusus yang harus dimiliki oleh mahasiswa tersebut.

World Economic Forum juga menekankan tentang akuisisi multiliterasi ketika menguraikan tentang keterampilan-keterampilan yang harus dikuasai seseorang untuk menghadapi berbagai kebutuhan hidup sehari-sehari mereka di abad ke-21. Keterampilan tersebut termasuk enam "literasi dasar", seperti literasi dasar membaca dan menulis, literasi numerik (berhitung/matematika) dan literasi sains, serta sepuluh keterampilan yang diberi label "kompetensi" atau "kualitas karakter". Sedangkan kompetensi adalah sarana di mana siswa menghadapi tantangan yang kompleks; mereka termasuk kolaborasi, komunikasi dan pemikiran kritis serta 
pemecahan masalah. Adapun kualitas karakter adalah cara di mana siswa menghadapi lingkungan mereka yang berubah, yaitu rasa ingin tahu, kemampuan beradaptasi dan kesadaran sosial dan budaya (World Economic Forum, 2016: 4).

Literasi dasar mengacu tentang penerapan keterampilan inti mahasiswa untuk tugas sehari-hari. Keterampilan ini berfungsi sebagai dasar di mana ia perlu membangun kompetensi dan kualitas karakter yang lebih maju. Kategori ini tidak hanya mencakup keterampilan literasi (membaca dan menulis) dan berhitung (literasi numerik), tetapi juga literasi sains, literasi teknologi informasi dan komputer, literasi keuangan, dan literasi budaya dan kewarganegaraan. Akuisisi keterampilan ini telah menjadi fokus pendidikan di seluruh dunia. Secara historis, kemampuan untuk memahami teks tertulis dan berhitung sudah cukup untuk masuk ke dunia kerja. Sekarang, keterampilan ini hanya mewakili titik awal di jalan menuju menguasai keterampilan abad ke-21 (World Economic Forum, 2015: 2).

Konsep dan praktik multiliterasi menghendaki mahasiswa mengeksplorasi dan mengkritisi beragam "teks" (Teks dalam pengertian yang luas, bukan terbatas pada tulisan tercetak, tetapi berbagai simbol bahasa yang bermakna), topik ataupun isu yang menarik dari berbagai disiplin ilmu (seperti ilmuilmu sosial, ilmu-ilmu kealaman, ilmu-ilmu agama dan ilmu-ilmu humaniora), serta mampu menggunakan beragam sistem komunikasi (bahasa, seni, musik, matematika dan drama) sebagai media mengkomunikasikan berbagai produk pemahaman kritis tersebut (Abidin, Mulyati dan Yunansah, 2017: 21). Materi pembelajaran multiliterasi mencakup beragam jenis teks di berbagai bidang ilmu.

Sejalan dengan uraian tersebut, konsep multiliterasi 
menyarankan paradigma integratif dalam pembelajaran. Hal ini yang kemudian menghubungkan dengan praktik integrasi keilmuan yang mendasari pengembangan akademik dan kelembagaan di berbagai UIN sebagaimana telah diuraikan. Ini pula yang menjadikan pembelajaran integratif, sebagaimana yang telah dipraktikan oleh UIN, adalah pembelajaran yang sesuai dengan kepentingan abad ke-21 (Abidin, Mulyati dan Yunansah, 2017: 69), dan sesuai dengan arahan World Economic Forum. Jika digambarkan, multiliterasi yang telah dipraktikan dalam bingkai integrasi keilmuan pada beberapa UIN yang telah diuraian adalah sebagai berikut.

Gambar 2. Multiliterasi dan Integrasi Keilmuan

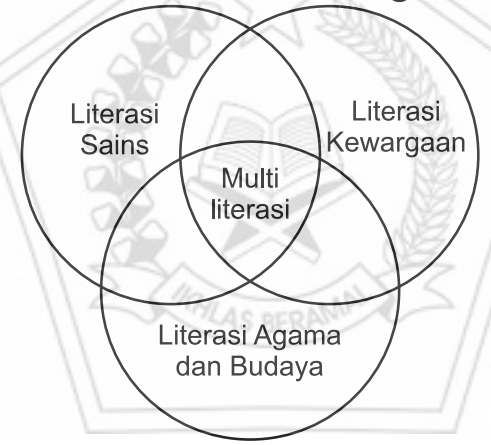

Gambar di atas sesuai dengan yang diajukan oleh Drake (2007) sebagaimana dikutip oleh Abidin, Mulyati dan Yunansah (2017: 69) dengan adaptasi untuk model multiliterasi. Drake sebagaimana dikutip oleh Abidin, Mulyati dan Yunansah (2017: 69) serta Drake dan Burns (2004: 12) menunjukkan beberapa model integrasi, yang salah satunya adalah model integratif-interdisipliner. Model ini yang kemudian akan melahirkan multiliterasi. Namun, sesuai dengan berbagai bidang ilmu yang ditekuni masingmasing mahasiswa, model ini tetap mengakui spesialisasi keilmuan atau spesialisasi literasi, namun berbagai 
pengetahuan yang ada dan berkembang digunakan untuk kepentingan penyelesaian permasalahan hidup, baik yang berupa permasalahan agama, sosial, budaya maupun alam. Sebagaimana dicontohkan oleh Amin Abdullah (2007: 3435), Fakultas Syariah misalnya, tidak boleh menolak untuk dimasuki mata kuliah baru yang mengandung muatan humaniora kontemporer dan ilmu-ilmu sosial seperti hermeneutika, cultural studies, HAM, sensitivitas gender, filsafat ilmu dan seterusnya. Jika tidak, maka mahasiswa akan mengalami kegagapan ketika keluar dari kampus dan berhadapan dengan realitas sosial-kemasyarakatan dan realitas sosial-keagamaan yang kompleks. Hal yang sama pun harus dilakukan oleh fakultas-fakultas yang lain. Dalam bahasa kajian literasi, seorang alumni UIN tidak hanya dituntut literat dalam bidang agama atau hukum Islam, tetapi juga literat di bidang-bidang lainnya sesuai tuntutan dan kebutuhan zaman. Literasi di abad 21 bertransformasi dari single-literacy (satu kemampuan literasi) ke multi-literacy (multiliterasi).

\section{Latar Waktu: Generasi Milenial}

Telah disebut bahwa konsep dan praktik integrasi keilmuan yang dilancarkan beberapa UIN sejalan dengan konsep dan praktik multiliterasi. Telah dijelaskan pula bahwa multiliterasi adalah bagian dari kebutuhan yang perlu dimiliki oleh generasi di abad ke-21. Dapat dikatakan bahwa generasi abad 21 adalah generasi multiliterasi. Generasi multiliterasi ini juga hidup di masa teknologi informasi yang semakin canggih, sebuah masa yang juga disebut dengan era milenial dan digital. Hal ini penting diketahui untuk bisa memahami karakter generasi yang menjadi subyek penelitian. 
Persoalan generasi yang menjadi latar waktu penelitian ini penting dikemukakan, sebab generasi sudah menjadi pembahasan penting para ahli sosiologi, seperti Karl Mannheim. Generasi bukanlah sebuah kelompok konkret masyarakat yang membentuk kesatuan atau kekeluargaan. Generasi adalah sebuah jenis lokasi kelas atau identitas tertentu yang menyarankan pada 'kelompok usia' yang terkait dengan suatu proses historis-sosial (Mannhiem, 1972: 292). Menurut Mannheim (1972: 320), generasi adalah salah satu faktor yang berkontribusi pada asal-usul dan dinamika perkembangan sejarah. Menurutnya, manusia di dunia akan saling mempengaruhi dan membentuk karakter yang sama karena hidup dan melewati masa sosio-historis yang sama. Problem generasi ini mengantarkan pada konsep "jiwa zaman" (spirit of age atau zeitgeist) yakni suatu pemikiran atau filsafat sosial tradisi Jerman yang berpandangan bahwa terdapat suatu pemikiran dominan yang mempengaruhi atau menggambarkan situasi sosial dan budaya pada masa tertentu (Mannheim, 1972: 284). Berdasarkan pandangan penting soal generasi yang terkait dengan masa atau waktu di mana partisipan hidup inilah, deskripsi dan penjelasan tentang siapa dan di mana posisi partisipan atau mahasiswa dalam rentang generasi yang telah ada, penting dikemukakan.

Salah satu yang biasa digunakan untuk mengkaji generasi adalah teori siklus generasi yang diajukan oleh William Strauss dan Neill Howe (1991). Penelitian kedua orang ini kemudian dirujuk oleh Faisal (2017) dalam banyak penelitiannya tentang budaya dan psikologi anak muda. Dalam buku Generations: The History of American Future 1584 to 2069, Strauss dan Howe mengulas sejarah Amerika Serikat dilihat dari satu generasi ke generasi berikutnya. 
Ulasannya ini dapat dibaca sebagai sebuah biografi generasi di Amerika yang mundur hingga abad ke-15. Selanjutnya mereka berdua menulis The Fourth Turning: An American Prophecy (1997). Sebagai kelanjutan dari Generations, dalam The Fourth Turning, keduanya mengembangkan teori empat siklus generasi di sepanjang sejarah Amerika. Masingmasing generasi tersebut memiliki corak yang khas (Faisal, 2017: 19-20).

Secara lebih rinci, teori siklus empat generasi Strauss dan Howe yang hidup hingga sekarang adalah sebagai berikut. Pertama generasi baby boom (terlahir pada tahun 1943-1960. Kedua generasi X (terlahir pada 1961-1981). Ketiga generasi $\mathrm{Y}$ atau yang kemudian sering disebut generasi milenial (terlahir 1982-2004). Keempat generasi Z (terlahir sejak tahun 2005) (Setowara, 2018: 1).

Menyadari akan kekurangan teorisasi Strauss dan Howe, Faisal mengajukan adaptasi dari teori siklus empat generasi yang terlalu menggambarkan anak muda Amerika. Menurut Faisal (2017: 26-27) anak-anak muda atau remaja yang hidup hingga sekarang ini (tahun 2017) di Indonesia adalah generasi yang dapat dimasukan dalam generasi $\Theta$ (omega), $\pi$ (phi) dan neo $\alpha$ (alpha). Generasi $\Theta$ adalah generasi yang tumbuh berkembang menjadi remaja pada akhir 1990-an. Sedangkan generasi $\pi$ adalah generasi milenial yang sekarang berada di kisaran usia 20-an. Adapun setelahnya, generasi neo $\alpha$ adalah generasi yang sering disebut dengan the gold generation, yakni generasi yang lahir di era milenium (setelah tahun 2000).

Masing-masing generasi ini memiliki karakter atau ciri masing-masing yang membedakan dari satu generasi dengan generasi lainnya. Generasi $\Theta$ dapat disebut generasi yang 
paling kreatif, dijuluki dengan the creator, yakni generasi yang banyak melakukan kreasi-kreasi yang menantang di berbagai bidang. Sedangkan generasi $\pi$ disebut dengan kurator, yakni generasi yang banyak melakukan kurasikurasi. Tidak terbatasnya dan kemudian mendapatkan informasi membuat generasi ini lebih sebagai seorang curator, yaitu memilih informasi yang akan dikemas menjadi sebuah kreasi. Lalu, generasi neo $\alpha$ disebut dengan The Cultivator Performer. Generasi ini sedang berada pada tahap mempelajari pengetahuan baru. Generasi ini juga tumbuh besar dengan telepon seluler, tablet dan media sosial yang sudah menjadi bagian dari kehidupan sehari-hari. Generasi ini akan dekat dengan aktivitas penampilan, karena memang mereka adalah sang penampil (performer). Berbeda dengan dua generasi sebelumnya, anak muda di generasi terakhir ini masih dalam proses perjalanan yang saling memengaruhi dengan generasi sebelumnya (Faisal, 2017: 28-20).

Gambaran tentang teori empat generasi yang ada di Indonesia memiliki masa remaja yang berbeda, ikon tokoh, tantangan zaman, cara pandang dan keterlibatan dengan gerakan sosial-politik yang berbeda. Berikut gambaran empat generasi yang disajikan dalam tabel. 


\section{Tabel 1. Gambaran Empat Generasi Indonesia}

\begin{tabular}{|c|c|c|c|c|}
\hline $\begin{array}{l}\text { Generasi/ } \\
\text { Era }\end{array}$ & $\begin{array}{l}\text { Ikon/ } \\
\text { Tokoh }\end{array}$ & $\begin{array}{c}\text { Tantangan } \\
\text { Zaman }\end{array}$ & $\begin{array}{c}\text { Cara } \\
\text { Pandang }\end{array}$ & $\begin{array}{c}\text { Gerakan } \\
\text { Sosial- } \\
\text { Politik }\end{array}$ \\
\hline $\begin{array}{l}\alpha(\text { Alpha) } \\
\text { Masa } \\
\text { remaja: } \\
1900-1930\end{array}$ & $\begin{array}{l}\text { Soekarno, } \\
\text { Tan } \\
\text { Malaka, } \\
\text { Sutan } \\
\text { Syahrir, } \\
\text { Hatta, Buya } \\
\text { Hamka }\end{array}$ & $\begin{array}{l}\text { Kolonialisme, } \\
\text { mempersatukan } \\
\text { bangsa. }\end{array}$ & $\begin{array}{l}\text { Tdeologis, } \\
\text { religius, } \\
\text { kedaerahan, } \\
\text { nasionalis, } \\
\text { komunal }\end{array}$ & $\begin{array}{l}\text { Budi } \\
\text { Oetomo, } \\
\text { Sarekat } \\
\text { Islam, } \\
\text { Perhimpunan } \\
\text { Pelajar- } \\
\text { Pelajar } \\
\text { Indonesia }\end{array}$ \\
\hline $\begin{array}{l}\beta \text { (Beta) } \\
\text { Masa } \\
\text { remaja: } \\
\text { 1930-1966 }\end{array}$ & $\begin{array}{l}\text { Adam } \\
\text { Malik, } \\
\text { Soeharto, } \\
\text { BJ Habibie, } \\
\text { Bung Tomo }\end{array}$ & $\begin{array}{l}\text { Ketidakstabilan } \\
\text { politik- } \\
\text { ekonomi, } \\
\text { membangun } \\
\text { republik, } \\
\text { masuknya } \\
\text { ideologi yang } \\
\text { dianggap } \\
\text { mengancam. }\end{array}$ & $\begin{array}{l}\text { Heorik, } \\
\text { optimis } \\
\text { terhadap } \\
\text { masa depan, } \\
\text { ideologis, } \\
\text { menjunjung } \\
\text { harga diri dan } \\
\text { kelompok. }\end{array}$ & $\begin{array}{l}\text { Partai } \\
\text { Politik (PNI, } \\
\text { Masyumi } \\
\text { dll) Kesatuan } \\
\text { Aksi } \\
\text { Mahasiswa } \\
\text { Indonesia } \\
\text { (KAMI) }\end{array}$ \\
\hline $\begin{array}{l}\Omega \\
\text { (Omega) } \\
\text { Masa } \\
\text { remaja: } \\
\text { 1970-1998 }\end{array}$ & $\begin{array}{l}\text { Twan Fals, } \\
\text { Hilman, } \\
\text { Budiman } \\
\text { Sudjatmiko, } \\
\text { Dono } \\
\text { Kasino } \\
\text { Indro, Rano } \\
\text { Karno, Roy } \\
\text { Marten. }\end{array}$ & $\begin{array}{l}\text { Kompetisi } \\
\text { tinggi, } \\
\text { individualisme, } \\
\text { keterbatasan } \\
\text { ruang } \\
\text { berekspresi, } \\
\text { pengaruh } \\
\text { budaya asing. }\end{array}$ & $\begin{array}{l}\text { Adaptif, } \\
\text { kompetitif, } \\
\text { social } \\
\text { climber, } \\
\text { orientasi } \\
\text { pada } \\
\text { pencapaian } \\
\text { hidup, } \\
\text { mengejar } \\
\text { standar } \\
\text { keahlian } \\
\text { tertentu. }\end{array}$ & $\begin{array}{l}\text { Gerakan } \\
\text { mahasiswa } \\
\text { di tingkat } \\
\text { fakultas } \\
\text { (PMMI, } \\
\text { HMI, GMNI, } \\
\text { KAMMI). }\end{array}$ \\
\hline
\end{tabular}




\begin{tabular}{lllll}
\hline$\pi$ (Phi) & Maudi & Pengaruh & Cenderung & Indonesia \\
Masa & Ayunda, Rio & perkembangan & pada & Youth \\
remaja: & Haryanto, & mobile dan & passion dan & Confrence, \\
awal & Dian & digital, korupsi & kreativitas, & Young on \\
abad 21 & Pelangi, & pemerintahan, & pluralis, & Top \\
& Raissa, & radikalisme, & komunal, & \\
& Aliando & pasar bebeas, & teralienasi & \\
& Syarief. & $\begin{array}{l}\text { pengaruh gaya } \\
\text { hidup dariluar. }\end{array}$ & dan sensitif & \\
& & & \\
\hline
\end{tabular}

Sumber: Faisal (2017: 7)

Tabel 2. Empat Generasi Menurut Strauss dan Howe

\begin{tabular}{cccc}
\hline Baby Boomer & Gen-X & Milenialls & Gen-Z \\
\hline $1946-1964$ & $1965-1980$ & $1981-2000$ & 2001-sekarang \\
\hline
\end{tabular}

Sumber: Ali dan Purwandi (2017: 4)

Terlepas dari teori generasi, baik yang diajukan oleh Strauss dan Howee maupun Faisal, sebetulnya anak-anak yang berusia 17-36 saat penelitian ini dilakukan dapat disebut dengan generasi milenial, karena mereka terlahir antara tahun 1981-2000, dan memasuki masa remaja pada awal abad ke21. Inilah rentang usia yang akan mengisi kehidupan 5-15 tahun mendatang. Usia inilah yang akan memenuhi ledakan usia produktif yang disebut dengan bonus demografi (Ali dan Purwandi, 2017: 16).

Uraian tentang teori generasi penting dijelaskan sebelum menentukan di mana posisi partisipan penelitian yang menjadi subyek penelitian kali ini. Hal ini akan memberikan implikasi pada analisis selanjutnya terhadap data yang ditemukan sebagaimana akan disampaikan di bab selanjutnya. Sebelum melangkah ke paparan lebih rinci mengenai letak atau posisi generasi para partisipan yang menjadi subyek penelitian ini, ada baiknya disampaikan terlebih dahulu kisaran usia mereka. 
Penelitian ini dilakukan dengan melibatkan sejumlah mahasiswa, yang kebanyakan di antara mereka adalah pengurus di Himpunan Mahasiswa Jurusan (HMJ) di masingmasing jurusan atau program studinya. Oleh karena itu, penelitian ini dalam melakukan wawancara kebanyakan juga kepada mahasiswa-mahasiswa yang duduk di semester dua hingga enam, selebihnya ada yang delapan, tetapi jarang. Namun secara umum mereka terlahir di tahun 1996 atau 1997 ke bawah. Hal ini diperkuat juga dari jawaban atas pertanyaan yang diajukan kepada sejumlah mahasiswa yang tidak terbatas pada mahasiswa yang aktif di HMJ. Mereka kebanyakan lahir di tahun 1996 atau 1997 ke bawah. Menurut data demografi yang diperoleh, dari sejumlah 1007 partisipan mahasiswa yang dilibatkan dalam penelitian di seluruh kampus lokasi penelitian, terbanyak lahir di tahun 1998, 1997 dan 1999.

Menurut data di atas, jelas mereka termasuk generasi Y dalam teori siklus generasi Strauss dan Howe, dan termasuk generasi $\Theta$ menurut teori generasi Faisal, atau secara singkat dapat disebut dengan generasi milenial. Ketiganya bisa dijadikan rujukan oleh karena beberapa ciri khusus yang diajukan oleh dua teori tersebut memiliki kesamaan. Beberapa ciri penting yang terkait dengan pembahasan penelitian ini dapat dijelaskan sebagai berikut.

Pertama, mereka dianggap sebagai native digital, tumbuh dalam masa dunia digital dan teknologi informasi yang berkembang dan canggih. Kedua, ketika belajar, generasi milenial lebih suka membaca PowerPoint daripada bukubuku tebal. Mereka merasa terbebani jika harus membaca buku tebal. Jikapun harus membaca buku yang tebal, maka yang dibaca adalah buku-buku novel yang disajikan dengan 
bahasa yang mudah. Uraian panjang tentang suatu pemikiran yang rumit sering kali dihindari, sebaliknya mereka lebih menyenangi kata-kata atau kutipan bijak yang memotivasi. Ketiga, generasi milenial sering kali merasa sibuk meskipun tidak jelas apa yang menyibukkan mereka. Keempat, generasi milenial juga mudah berpindah-pindah kerjaan dari satu tempat ke tempat lain. Kelima, generasi milenial terbiasa melakukan banyak hal dalam satu waktu (multitasking) meskipun kurang mendalam (Rukmana, 2018: 197-199). Karena itu mereka akan selalu terhubung dengan "dunia luar" di satu sisi, tetapi juga cenderung pragmatis di sisi lain.

Lebih lanjut dalam soal menulis, mengandalkan internet adalah kekuatan generasi milenial dalam menulis. Internet menjadi salah satu sumber utama - jika bukan sumber satusatunya - dalam menulis di kalangan milenial, baik menulis tugas makalah, buku, esai atau sekadar status di media sosial. Namun, internet pun menyisakan masalah lemahnya verifikasi data di kalangan generasi milenial. Bahan yang digunakan mereka dari internet terkadang hanya sumbersumber sekunder dari blog, bahkan tidak jarang dari halamanhalaman yang diragukan keabsahannya (Syukur, 2018: 217218).

Ciri lain yang juga menonjol adalah generasi milenial Indonesia ini sebetulnya memiliki ikatan komunal. Dia tidak bisa hidup sendirian. Dia harus selalu berkerumun, hidup dalam satu lingkungan komunal yang saling bertinteraksi, saling mendukung satu sama lain, serta ada perasaan kepemilikan yang kuat antara dirinya dan kelompok tersebut. Hal yang juga terkait dengan karakter komunal ini adalah "budaya berbagi" atau culture sharing. Dengan budaya berbagi ini, semua isu dan masalah yang dialami generasi 
milenial Indonesia memiliki batasan sosial yang tipis. Setiap isu dan permasalahan yang dihadapi seorang anak muda harus dibagikan kepada teman-teman terdekat (Faisal, 2017: 60).

Disebabkan oleh karakter komunalitas ini, anak-anak muda generasi milenial secara psikologis memiliki kebutuhan untuk mengonfirmasi apakah yang mereka lakukan, rasakan, atau pikirkan sudah benar atau sudah berada di jalur yang benar menurut komunitas mereka. Peer group (grup sebaya), komunitas dan lingkungan sosial secara luas berfungsi sebagai tempat mendapatkan konfirmasi tersebut. Melalui konfirmasi grup sebaya, mereka ingin dapat diterima (to be accepted), disetujui atau diaminkan secara sosial (socialy approved), dan mengurangi ketidakpastian (mengurangi ketidakpastian). Anak muda saat ini lebih memprioritaskan pengetahuan yang sesuai dengan apa yang diperbincangkan oleh grup sebaya, lingkungan sosial maupun forum-forum online maupun offline (Faisal, 2017: 147-148).

Anak-anak yang lahir di tahun 1997, 1998 dan 1999 jelas terlahir pada masa yang sudah berbeda dari generasi sebelumnya. Mereka lahir di batas milenium dan awal reformasi, meski mereka tidak mengalami peristiwa reformasi tersebut. Karena itu mereka terlahir dan tumbuh pada masa keterbukaan informasi. Mereka sudah sejak awal dapat memilih informasi mana yang harus diterima bahkan diikuti. Mereka lahir pada masa yang menyongsong era revolusi digital, karena itu mereka sudah sangat akrab dengan dunia teknologi informasi sejak anak-anak. Mereka juga dapat disebut dengan generasi mobile. Inilah latar generasi yang mendasari praktik literasi mereka.

Karakter lain yang diajukan oleh Ali dan Purwandi (2017: 81-96) berdasarkan hasil penelitian kualitatifnya adalah: 
generasi milenial itu connected (terhubung), creative (kreatif) dan confidence (percaya diri). Genearasi milenial adalah generasi yang selalu terhubung, yakni pandai bersosialisasi, terutama dalam komunitas yang mereka ikuti baik di dunia nyata maupun di media sosial dan internet. Mereka juga adalah orang-orang yang biasa berpikir secara out of the box, kaya akan ide dan gagasan serta mampu mengomunikasikan dengan cemerlang. Mereka juga adalah orang-orang yang percaya diri, berani mengemukakan pendapat, dan tidak sungkan untuk berdebat di depan publik.

Menurut Ali dan Purwandi (2017: 85), seperti generasi milenial di belahan dunia lainnya, generasi milenial adalah generasi yang selalu terhubung, bersosialisasi, meskipun di dunia maya. Penyebabnya adalah internet dan gawai yang mereka miliki. Data statistik yang dikeluarkan/oleh Alvara Research Center, menunjukkan $72,2 \%$ anak muda milenial mengakses internet (Ali dan Purwandi, 2017: 59). Bahkan menurut partisipan penelitian ini, dalam sehari mereka dapat mengakses internet untuk mencari informasi dan media sosial lebih dari lima jam. Melalui gawai dan internet, mereka terhubung dengan orang lain di daerah lain, pulau lain bahkan hingga di belahan negara lain. Tidak hanya terhubung dengan orang-orang yang dikenalnya, tetapi juga dengan berita atau kejadian yang terjadi di belahan dunia lain. Melalui akses secara online, mereka dapat mengakses berita, informasi dan pengetahuan yang sebelumnya sama sekali mereka tidak ketahui.

Demikian uraian tentang latar tempat dan waktu yang menjadi situs penting berlakunya penelitian ini. Dengan landasan dua latar ini, analisis-analisis selanjutnya yang diajukan berdasarkan data pada bab-bab selanjutnya akan 
berupaya mengacu pada uraian dua latar ini. Dua latar ini menjadi pananda penting praktik literasi yang dilakukan oleh mahasiswa UIN di berbagai wilayah penelitian. Dengan dua latar ini diketahui siapa sesunggunya partisipan penelitian yang menjadi subyek dan di mana mereka menjalani pendidikan. Dapat dikatakan juga, dua latar tersebut bisa dijadikan konteks berlangsungnya praktik literasi mahasiswa. 


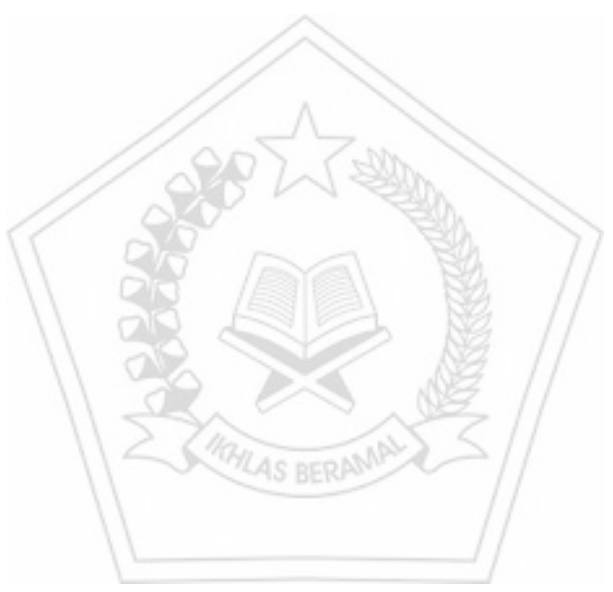




\section{BAB III \\ INFRASTRUKTUR LITERASI \\ MAHASISWA: \\ KONDISI PERPUSTAKAAN, \\ PEMANFAATAN, DAN TANTANGAN \\ MEDIA ONLINE}

Sebelum membahas tentang praktik literasi mahasiswa, terlebih dahulu perlu diuraikan tentang beberapa kondisi infrastruktur literasi yang dapat atau tidak mendukung praktik literasi yang berlangsung di beberapa kampus yang menjadi lokasi penelitian. Hal ini penting untuk melihat kondisi infrastruktur literasi dalam lembaga yang menjadi -sponsor praktik literasi”. Kondisi infrastruktur tersebut dapat juga disebut sebagai wadah dan fasilitas yang memungkinkan peristiwa literasi terjadi. Sebagaimana telah diuraikan di bagian pendahuluan, himpunan peristiwa literasi adalah kegiatan menggunakan teks yang terjadi dalam konteks tertentu. Himpunan peristiwa literasi yang berpola inilah yang kemudian disebut sebagai praktik literasi. Untuk mempraktikan literasi diperlukan infrastruktur yang 
mendukung literasi.

Pembahasan infrastruktur ini lebih terfokus pada kondisi perpustakaan dan pemanfaatannya serta ketersediaan produksi dan distribusi ilmu pengetahuan melalui media online atau digital. Kedua hal tersebut penting, karena perpustakaan sebagai bagian penting infrastruktur literasi, dan median online sebagai bagian dari perkembangan teknologi dalam generasi milenial sekarang ini. Berikut ulasan tentang kondisi perpustakaan sebagai bagian penting infrastruktur literasi.

\section{Kondisi Perpustakaan}

\section{UIN Sunan Kalijaga Yogyakarta}

Visi perpustakaan UIN Sunan Kalijaga adalah sebagai perpustakaan penelitian berbasis keislaman dan keilmuan. Adapaun misi perpustakaan UIN Sunan Kalijaga adalah: 1) mengembangkan sumber-sumber belajar yang unggul dalam bidang keislaman dan keilmuan; 2) meningkatkan akses ke sumber-sumber penelitian dalam bidang keislaman dan keilmuan berbasis teknologi informasi; 3) meningkatkan kualitas layanan prima yang sesuai dengan perkembangan teknologi informasi; dan 4) memperkuat hubungan kerja sama dengan lembaga terkait untuk meningkatkan akses ke sumber-sumber yang relevan.

Perpustakaan UIN Sunan Kalijaga memiliki koleksi judul sebanyak 47.312 dan 168.436 eksemplar. Koleksi tersebut terdiri dari berbagai bahasa, yakni bahasa Indonesia, Inggris, dan Arab serta bahasa-bahasa lainnya. Buku-buku tersebut juga terdiri dari beragam subyek, mulai dari bukubuku keislaman hingga buku-buku umum. Berikut statistik koleksi Perpustakaan UIN Sunan Kalijaga Yogyakarta. 
Tabel 3. Jumlah Koleksi Perpustakaan UIN Sunan Kalijaga

\begin{tabular}{|c|c|c|c|c|}
\hline \multirow{2}{*}{ No } & \multirow{2}{*}{ Kelas } & \multirow{2}{*}{ Jenis Koleksi } & \multicolumn{2}{|c|}{ Jumlah } \\
\hline & & & Judul & Eks \\
\hline 1 & $2 \mathrm{X} 0$ & Islam (umum) & 1.330 & 5.820 \\
\hline 2 & $2 \mathrm{X} 1$ & Alquran & 1.800 & 9.467 \\
\hline 3 & $2 \times 2$ & Hadits & 988 & 5.595 \\
\hline 4 & $2 \times 3$ & Aqidah dan Ilmu kalam & 1.310 & 4.463 \\
\hline 5 & $2 \mathrm{X} 4$ & Fiqih dan Hukum Islam & 3.529 & 14.559 \\
\hline 6 & $2 \times 5$ & Akhlak dan Tasawuf & 1.348 & 4.817 \\
\hline 7 & $2 \times 6$ & Sosial Budaya & 2.092 & 7.448 \\
\hline 8 & $2 \times 7$ & Fil \& Perkembangan & 2.392 & 9.704 \\
\hline 9 & $2 \mathrm{X} 8$ & Aliran dan Sekte & 296 & 921 \\
\hline 10 & $2 \times 9$ & Sejarah dan Biografi & 2.046 & 7.798 \\
\hline 11 & 000 & Karya Umum & 2.469 & 7.593 \\
\hline 12 & 100 & Filsafat & 2.093 & 7.562 \\
\hline 13 & 200 & Agama & 1.683 & 6.371 \\
\hline 14 & 300 & Ilmu Sosial & 10.738 & 35.463 \\
\hline 15 & 400 & Bahasa & 1.864 & 6.194 \\
\hline 16 & 500 & IPA $>$ & 2.100 & 7.331 \\
\hline 17 & 600 & Ilmu Terapan & 4.169 & 13.029 \\
\hline 18 & 700 & Kesenian \& Olahraga & 549 & 1.589 \\
\hline 19 & 800 & Kesusasteraan & 2.422 & 7.107 \\
\hline 20 & 900 & Sejarah dan Biografi & 2.094 & 5.605 \\
\hline & & & 47.312 & 168.436 \\
\hline
\end{tabular}

Sumber: Perpustakaan UIN Sunan Kalijaga Yogyakarta

Koleksi tersebut belum ditambah koleksi digital dan perpustakaan-perpustakaan di masing-masing fakultas. Jenis koleksi digital yang dilayankan di Perpustakaan UIN Sunan Kalijaga antara lain: e-journal, e-book, digital library, difarepositories, maktabah shamilah, dan CD atau DVD. Selain koleksi tercetak dan digital, di perpustakaan UIN Sunan Kalijaga terdapat pula beberapa pojok baca seperti; Iranian Corner, Canadian Corner, dan Saudi Arabian Corner. 
Layanan jurnal pada UIN Sunan Kalijaga dapat dilihat dari layanan serial. Layanan serial merupakan layanan yang menyediakan koleksi berupa publikasi yang terbit secara berkala, baik jurnal ilmiah maupun populer. Layanan serial menyediakan berbagai publikasi dari dalam dan luar negeri yang hanya dapat diakses atau dibaca di tempat atau fotokopi di perpustakaan. Jenis koleksi serial di Perpustakaan UIN Sunan Kalijaga dibagi menjadi dua yaitu koleksi serial tercetak dan koleksi serial elektronik.

Berikut adalah koleksi serial tercetak Perpustakaan UIN Sunan Kalijaga; 1) studi dan pemikiran Islam: Jurnal Al Jami'ah, Jurnal Ulumuna, Jurnal Ibda', Jurnal Dialogia, Jurnal Al-Ulum, Jurnal Akademika, Jurnal Al-Ijtihad dan lain-lain. Jurnal tercetak tentang perpustakaan diantaranya; Fihris, Al Maktabah, WIPA, Bilbiokusuka, Media Informasi, Sangkakala dan lain-lain. Kemudian koleksi jurnal yang memuat artikel ekonomi diantaranya; Al-Iqtishad, Jurnal Eksibisi dan lain-lain. Jurnal pendidikan; Indo-Islamika, Nadwa, Tadris, Mukaddimah, Lecture dan lain sebagainya. Kemudian jurnal tentang dakwah diantaranya; Dialog, Jurnal Ilmu dakwah, Jurnal Bina Al Ummah. Kemudian Jurnal Ilmu Sosial Budaya, koleksinya adalah Jurnal Islamic culture, Ulumul Quran, Al-Tajdid, dan Madania. Jurnal sains dan teknologi koleksi yang dilanggan adalah Jurnal sains dan teknologi dan jurnal matematika.

Koleksi jurnal online yang dilanggan perpustakaaan UIN Sunan Kalijaga antara lain; Emerald, SAGE Research Method, Oxford Journal, JSTOR, AAAS, Ebsco Host, Moraref, dan local journal. Untuk jurnal Emerald subyek dari jurnal ini adalah economics, library information studies, education, dan international business. Jurnal ini dapat diakses 
dari luar UIN Sunan Kalijaga menggunakan username dan password. Kemudian untuk SAGE Research Method adalah materi-materi tentang metodologi riset, yang berupa buku, video, referensi, studi kasus, perencanaan penelitian dan lain-lain. SAGE Research Methods dapat diakses internet di lingkungan kampus UIN Sunan Kalijaga melalui link http:// methods.sagepub.com/.

Selanjutnya terdapat Oxford Journals yang berisi tentang beberapa subyek yang dapat diakses seperti; art and humanities, law, medicine and health, science and mathematics, dan social science. Oxford Journals dapat diakses di lingkungan kampus UIN Sunan Kalijaga melalui http://academic.oup.com/journals/. Selanjutnya mengenai JSTOR, e-journal ini merupakan database yang mencakup berbagai bidang ilmu termasuk ilmu-ilmu keislaman, diantaranya; art, bisnis dan ekonomi, sejarah, hukum, humaniora, kesehatan, matematika, dan ilmu-ilmu sosial lainnya. JSTOR dapat diakses melalui http://www.jstor. org/. Tentang AAAS, link ini merupakan database sains dalam bentuk jurnal, berita (news), majalah, karir, blog, dan multimedia. Untuk jurnal AAAS dapat diakses melalui http:// science.sciencemag.org/. Kemudian untuk Ebsco Host, link ini merupakan database e-journal yang mencakup subyeksubyek tentang dunia Arab atau Timur Tengah. Ebsco Host dapat diakses dengan username dan password yang bisa didapat di bagian referensi maupun informasi. Kemudian untuk link Moraref, ini merupakan database dari Ministry of Religious Affairs' Reference. Moraref adalah portal akademik yang diinisiasi oleh Kementerian Agama RI yang mencakup jurnal-jurnal yang diterbitkan oleh PTKIN di lingkungan Kementerian Agama RI. Moraref dapat diakses melalui http:// 
moraref.or.id. Sedangkan untuk local journal, ELMI adalah online journal collection yang berisi kumpulan database jurnal yang pernah dilanggan perpustakaan dan dapat diakses di lingkungan kampus UIN Sunan Kalijaga dengan alamat http://elmi.lib.uin.-suka.ac.ad/.

Beberapa jenis layanan sirkulasi Perpustakaan UIN Sunan Kalijaga adalah: layanan koleksi multimedia dan layanan tandon. Layanan koleksi multimedia dilakukan untuk membantu proses kegiatan belajar mengajar, layanan sirkulasi menyediakan koleksi multimedia berupa CD dengan berbagai subyek seperti; psikologi, ekonomi, manajemen, hukum dan lain-lain. Kemudian untuk layanan tandon merupakan koleksi cadangan dengan kode (C.1) yang hanya bisa dibaca di tempat atau difotokopi di perpustakaan. Layanan sirkulasi di Perpustakaan UIN Sunan Kalijaga semua berbasis elektronik.

Berdasarkan data pengunjung Perpustakaan UIN Sunan Kalijaga, dapat diketahui bahwa dalam tahun 2017 jumlah pengunjung di perpustakaan ini mencapai 339.308 orang. Berikut ini adalah data pengunjung berdasarkan fakultas pada tahun kunjungan 2017. Mahasiswa yang paling banyak berkunjung adalah mahasiswa dari Fakultas Ilmu Tarbiyah dan Keguruan.

Tabel 4. Data Pengunjung Perpustakaan UIN Sunan

Kalijaga Tahun 2017.

\begin{tabular}{|c|c|c|}
\hline No & Fakultas & Jumlah \\
\hline 1 & Adab & 37.830 \\
\hline 2 & Dakwah & 43.802 \\
\hline 3 & Tarbiyah & 47.085 \\
\hline 4 & FEBI & 29.665 \\
\hline 5 & Humaniora & 21.434 \\
\hline 6 & Pascasarjana & 28.195 \\
\hline
\end{tabular}




\begin{tabular}{llr}
\hline 7 & Ushuluddin & 46.143 \\
\hline 8 & SAINSTEK & 34.564 \\
\hline 9 & Syariah & 42.994 \\
\hline 10 & Dosen & 517 \\
\hline 11 & Pegawai & 412 \\
\hline 12 & Tamu & 6.667 \\
\hline Jumlah & 339.308 \\
\hline
\end{tabular}

Sumber: Perpustakaan UIN Sunan Kalijaga Yogyakarta

Jika melihat data peminjaman, bulan-bulan mahasiswa banyak meminjam buku adalah bulan Maret-April dan Oktober-November. Bulan-bulan tersebut adalah bulanbulan aktif perkuliahan dan mahasiswa banyak mengerjakan tugas, oleh karena itu mereka banyak meminjam buku di perpustakaan. Berikut tabel yang menunjukkan statistik peminjaman buku.

Tabel 5. Data Peminjaman Koleksi Perpustakaan UIN Sunan Kalijaga Tahun 2017

Jan Feb Mar Apr Mei Jun Jul Agus Sept Okt Nop Des Jumlah

5.0026.4278.3686.8916.7993.723 1.511 1.8626.3997.4887.1617.070 6.8701

Sumber: Perpustakaan UIN Sunan Kalijaga Yogyakarta

\section{UIN Walisongo Semarang}

Perpustakaan UIN Walisongo Semarang terdiri dari beberapa perpustakaan, pertama perpustakaan pusat, dan kedua perpustakaan di beberapa fakultas, yakni Fakultas Ilmu Tarbiyah dan Keguruan, Fakultas Syariah dan Hukum dan Fakultas Ushuluddin dan Humaniora, serta Fakultas Dakwah dan Komunikasi (UPT Perpustakaan UIN Walisongo Semarang, 2017: 9). Perpustakaan UIN Walisongo bervisi menjadi pusat kegiatan komunikasi ilmiah 
dalam mengembangkan ilmu pengetahuan, pembelajaran dan penelitian. Adapun misinya adalah: (1) menyediakan sumberdaya informasi yang berkualitas untuk pembelajaran dan penelitian; (2) menyediakan fasilitas dan sarana belajar serta akses informasi ilmiah seluas-luasnya kepada komunitas akademik UIN Walisongo dan masyarakat luas, dan (3) mengoptimalkan pengelolaan fasilitas dan aset dalam rangka peningkatan mutu layanan perpustakaan (UPT Perpustakaan UIN Walisongo Semarang, 2017: 8).

Beberapa jenis layanan Perpustakaan UIN Walisongo adalah sebagai berikut. (1) Peminjaman koleksi, yakni Perpustakaan UIN Walisongo menyediakan layanan peminjaman menggunakan sistem terbuka (pemustaka bisa akses langsung kepada koleksi; (2) Layanan referensi, yakni layanan bahan referensi, seperti kamus, sumber biografi, sumber geografi, terbitan pemerintah, ensiklopedi, direktori, buku pegangan/pedoman/handbooks/manual, dan buku tahunan atau almanak (memuat informasi tentang kejadian penting pada tahun tertentu, dalam bentuk deskriptif, statistik dan tabel. Layanan referensi ini hanya untuk dibaca ditempat dan difotokopi; (3) Penelusuran literatur, yakni penyediaan jasa penelusuruan literatur bagi pengguna yang sedang melakukan penelitian, baik tugas akhir (skripsi dan tesis) maupun tugas lainnya (makalah) yang membutuhkan rujukan, baik berupa buku, artikel jurnal, dan prosiding; (4) Bimbingan pemakai, yakni bimbingan pemakai yang utamanya bagi mahasiswa baru setiap tahun. Tujuannya adalah memberikan pembekalan bagi mahasiswa untuk memperoleh pengetahuan dan keterampilan dasar sebagai salah satu sarana yang penting dalam studi; (5) Layanan internet, yakni peneliti memberikan layanan akses internet 
secara gratis yang dibuka setiap hari kerja; (6) Kartu Super FPPTI (Forum Perpustakaan Perguruan Tinggi Indonesia), yakni sebuah kerjasama antar perpustakaan perguruan tinggi di Indonesia yang menyediakan pelayanan peminjaman antar anggota; (7) American Corner, yakni pusat informasi yang dikembangkan atas kerjasama UIN Walisongo dengan Kedutaan Besar Amerika Serikat di Jakarta. American Corner menyediakan sumber-sumber informasi ilmiah dalam bentuk buku, jurnal, CD-ROM, DVD dan jurnal elektronik. Semua koleksi ini hanya untuk dibaca di tempat atau difotokopi. Selain itu, di tempat ini, pengguna juga dapat mengakses informasi melalui internet; (8) Penyelenggaraan kegiatan, yakni menyelenggarakan berbagai kegiatan yang bersifat edukatif, intelektual, rekreatif dan kultural seperti seminar, diskusi, bedah buku, talkshow, dan pemutaram film. Kegiatankegiatan tersebut dilaksanakan secara regular maupun insidental (UPT Perpustakaan UIN Walisongo Semarang, 2017: 13-14).

Berdasarkan uraian tersebut, Perpustakaan UIN Walisongo telah menyediakan layanan yang memungkinkan terjadinya peristiwa dan praktik literasi mahasiswa. Selain menyediakan berbagai layanan koleksi perpustakaan, tampak bahwa Perpustakaan UIN Walisongo juga memfasilitasi beberapa peristiwa literasi, seperti bedah buku, talkshow dan bedah film. Ketiga kegiatan ini dapat disebut sebagai penyediaan fasilitas atau infrastruktur yang memungkinkan terjadinya praktik literasi.

Adapun koleksi yang dimiliki oleh Perpustakaan di lingkungan UIN Walisongo Semarang hingga saat ini adalah sebagai berikut. 
Tabel 6. Jumlah Koleksi Perpustakaan di Lingkungan UIN Walisongo

\begin{tabular}{lrr}
\hline \multicolumn{1}{c}{ Perpustakaan } & Judul & Eksemplar \\
\hline UPT Perpustakaan Pusat & 24.633 & 83.763 \\
\hline American Corner & 2.273 & 2.459 \\
\hline Fakultas Dakwah dan Komunikasi & 2.959 & 7.003 \\
\hline Fakultas Syariah dan Hukum & 5.120 & 12.554 \\
\hline Fakultas Ilmu Tarbiyah dan Keguruan & 15.509 & 45.478 \\
\hline Fakultas Ushuluddin dan Humaniora & 5.269 & 12.873 \\
\hline Pascasarjana & 6.510 & 14.503 \\
\hline
\end{tabular}

Sumber: UPT Perpustakaan UIN Walisongo Semarang (2017: 15)

Selain koleksi buku yang sudah disebutkan, UPT Perpustakaan UIN Walisongo juga memiliki sejumlah koleksi bukan buku (nonbook materials), yakni:

1. Surat kabar langganan yang berjumlah enam judul.

2. Majalah popular langganan empat judul.

3. Skripsi/tesis/disertasi dan laporan penelitian.

4. Ribuan full text artikel jurnal elektronik dari empat database yang dapat diakses dari jaringan internet kampus, yaitu:

a. Cambridge Journal Online (CJO)

b. Oxford Journals

c. Emerald Journals

d. EbscoHost

5. Database Elibrary USA yang dapat diakses melalui American Corner.

6. CD-ROM, VCD/DVD sebanyak lebih dari 500 judul.

7. Digital Library (karya akhir mahasiswa) terdiri atas 11.738 judul (UPT Perpustakaan UIN Walisongo Semarang, 2017: 15). 
Jenis koleksi yang terdapat di UPT Perpustakaan UIN Walisongo terdiri dari koleksi buku teks (textbook), fiksi, referensi dan tandon. Jumlah eksemplar untuk masingmasing jenis koleksi tersebut adalah 645.369 eksemplar untuk jenis buku teks, 10.512 eksemplar untuk jenis koleksi fiksi, 1.916 eksemplar untuk jenis koleksi referensi dan 84 eksemplar untuk jenis koleksi tandon. Hal yang menarik di sini adalah, Perpustakaan UIN Walisongo menyediakan bacaan-bacaan fiksi meskipun jumlahnya lebih sedikit di banding koleksi buku teks. Hal ini menjadi bukti bahwa kesenangan mahasiswa dalam membaca fiksi telah difasilitasi oleh koleksi perpustakaan. Tabel statistik jumlah eksemplar untuk jenis koleksi dapat ditampilkan sebagai berikut.

Tabel 7. Jumlah Eksemplar Berdasarkan Jenis Koleksi

Perpustakaan UIN Walisongo

\begin{tabular}{cc}
\hline Jenis Koleksi & Jumlah Eksemplar \\
\hline Buku teks & 645.369 \\
\hline Fiksi & 10.512 \\
\hline Referensi & 1.916 \\
\hline Tandon & 84 \\
\hline
\end{tabular}

Sumber: Laporan statistik UPT Perpustakaan UIN Walisongo

Adapun data tentang jumlah judul perkoleksi dan eksemplar di masing-masing klasifikasi koleksi menunjukkan, bahwa koleksi terbanyak adalah tentang agama, baik dari sisi jumlah judul maupun eksemplar. Hal ini dapat dipahami karena lembaga ini pada awalnya adalah sebagai lembaga studi agama, dan fakultas-fakultas yang pertama dibuka adalah fakultas-fakultas yang berbasis agama. Selanjutnya, rincian statistik jumlah judul dan eksemplar untuk koleksi per klasifikasi adalah sebagai berikut. 
Tabel 8. Jumlah Judul dan Eksemplar Per Klasifikasi Koleksi di Perpustakaan UIN Walisongo

\begin{tabular}{lrr}
\hline \multicolumn{1}{c}{ Klasifikasi } & $\begin{array}{c}\text { Jumlah } \\
\text { Judul }\end{array}$ & \multicolumn{1}{c}{$\begin{array}{c}\text { Jumlah } \\
\text { Eksemplar }\end{array}$} \\
\hline Karya umum & 1.145 & 2.963 \\
\hline Ilmu filsafat & 1.330 & 4.715 \\
\hline Agama & 11.303 & 45.176 \\
\hline Ilmu-ilmu sosial & 6.173 & 19.082 \\
\hline Bahasa & 876 & 2.523 \\
\hline Ilmu-ilmu murni & 1.073 & 2.871 \\
\hline Ilmu-ilmu terapan (teknologi) & 2.180 & 5.347 \\
\hline Kesenian dan olahraga & 190 & 393 \\
\hline Kesusastraan & 741 & 1.754 \\
\hline Sejarah dan geografi & 937 & 2.577 \\
\hline
\end{tabular}

Sumber: Data Statistik UPT Perpustakaan UIN Walisongo Semarang

Kunjungan mahasiswa, terutama mahasiswa S1 tampak lebih banyak di bulan-bulan Maret dan September-Oktober. Berikut tabel jumlah kunjungan mahasiswa S1 tiap bulan di tahun 2017.

Tabel 9. Jumlah Kunjungan Mahasiswa S1 Per Bulan di Tahun 2017 di Perpustakaan UIN Walisongo

\begin{tabular}{cccccccccccc}
\hline Jan & Feb & Mar & Apr & Mei & Jun & Jul & Agu & Sep & Okt & Nop & Des \\
\hline 995 & 742 & 7.134 & 6.109 & 5.422 & 2.848 & 415 & 722 & 6.198 & 8.135 & 6.361 & 5.638 \\
\hline
\end{tabular}

Sumber: Data Statistik UPT Perpustakaan UIN Walisongo Semarang

Bulan-bulan di mana mahasiswa libur, yakni bulan Januari, Februari, Juli, dan Agustus menjadi bulan-bulan yang jumlah kunjungannya sedikit, bahkan di bawah 1000 kunjungan. Sementara bulan-bulan Maret, September dan Oktober adalah bulan-bulan aktif perkuliahan. Bulan-bulan itu juga menjadi bulan menjelang ujian akhir semester yang biasanya tugas-tugas kuliah lebih banyak, sehingga 
mahasiswa harus ke perpustakaan untuk mencari sumbersumber kepustakaan sebagai bahan pembuatan tugas kuliah.

\section{UIN Sunan Ampel Surabaya}

Perpustakaan UIN Sunan Ampel (UINSA) menempati gedung tiga lantai dengan luas bangunan 2800 M2. Bangunan ini dirancang untuk memberikan kenyamanan baik kepada pengelola maupun kepada seluruh pemustaka. Kenyamanan ruang dan sarana baca menjadi prioritas, meliputi; desain gedung yang sesuai dengan kebutuhan aktifitas perpustakaan, penyusunan rak koleksi berbasis pada secure (keamanan), comfortable (kenyamanan), dan accessible (mudah diakses). Hal ini diharapkan koleksi aman dari kerusakan dan pengguna nyaman untuk menggunakannya. Ruang baca didesain dengan menghargai privasi pemustaka. Penerangan sesuai standar kesehatan dan seluruh ruangan dilengkapi dengan AC (http://www.library.uinsby.ac.id.).

Koleksi perpustakaan tidak hanya dapat diakses secara langsung, tetapi juga dapat diakses secara online melalui icon online catalog, digital library, dan e-resources lainnya. Beberapa titik akses dikemas dalam sebuah situs online library.uinsby.ac.id. Perpustakaan juga menyediakan ruang lobi pengunjung yang dilengkapi dengan sarana televisi, bahkan pada hari-hari tertentu perpustakaan juga menyuguhkan sajian pemutaran film-film terkini yang berorientasi pada pengembangan wawasan pengetahuan (http://www.library.uinsby.ac.id.).

Visi Perpustakaan UINSA adalah "Menjadi perpustakaan yang unggul dan kompetitif dalam bidang keislaman." Sedangkan misinya sebagai berikut; 1) Menyediakan 
sumber pendidikan ilmu-ilmu keislaman multidisipliner serta sains dan teknologi yang unggul dan berdaya saing; 2) Mendiseminasikan hasil riset ilmu-ilmu keislaman multidisipliner serta sains dan teknologi yang relevan dengan kebutuhan masyarakat; 3) Menunjang pengabdian dalam pemberdayaan masyarakat yang religius berbasis riset (http://www.library.uinsby.ac.id.).

Perpustakaan UIN Sunan Ampel memiliki aneka koleksi monograf dan serial, baik berupa fiksi atau non fiksi, dalam bentuk cetak dan digital. Koleksi monograf dan serial selain disajikan secara langsung juga disajikan secara online dalam format E-Book, E-Journal, dan Repository. Format sajian elektronik disuguhkan untuk memudahkan akses tanpa batas dari berbagai belahan dunia (http://www.library.uinsby. ac.id.).

Statistik koleksi perpustakaan UIN Sunan Ampel selama tahun 2017 dan 2016 dapat ditampilkan sebagai berikut.

Tabel 10. Koleksi dan Kondisi Peminjaman Koleksi di Perpustakaan UIN Sunan Ampel Surabaya

\begin{tabular}{lrr}
\hline \multicolumn{1}{c}{ Tahun } & $\mathbf{2 0 1 7}$ & $\mathbf{2 0 1 6}$ \\
\hline Total Judul & 75.318 & 72.999 \\
\hline $\begin{array}{l}\text { Total Judul dengan } \\
\text { eksemplar }\end{array}$ & 60.762 & 58.259 \\
\hline Total Eksemplar/Kopi & 119.450 & 112.790 \\
\hline $\begin{array}{l}\text { Total Eksemplar } \\
\text { dipinjam Eksemplar }\end{array}$ & 2.168 & 1.842 \\
\hline $\begin{array}{l}\text { Total } \\
\text { dalam koleksi }\end{array}$ & 117.282 & 110.948 \\
\hline $\begin{array}{l}\text { Total Judul Menurut } \\
\text { Media: }\end{array}$ & & \\
\hline a) Buku & 34.588 & 33.866 \\
\hline b) Skripsi & 24.638 & 23.610 \\
\hline
\end{tabular}




\begin{tabular}{lrr}
\hline c) Artikel & 9.503 & 9.047 \\
\hline d) Koran & 4.298 & 4.310 \\
\hline e) Tesis & 1.220 & 1.102 \\
\hline f) Jurnal & 277 & 276 \\
\hline g) American Corner & 254 & 254 \\
\hline h) Disertasi & 132 & 109 \\
\hline i) Print & 3 & 2 \\
\hline
\end{tabular}

Total Eksemplar

Menurut Koleksi:

\begin{tabular}{|c|c|}
\hline a) Koleski Umum & 75.501 \\
\hline b) Koleksi Khusus & 26.528 \\
\hline c) Koleksi Tandon & 12.655 \\
\hline \multirow{2}{*}{\multicolumn{2}{|c|}{$\begin{array}{lr}\text { d) Koleksi Reference } & 5.480 \\
\text { e) Koleksi Islam } & 40\end{array}$}} \\
\hline & \\
\hline \multirow[t]{9}{*}{10 Judul Terpopuler } & $\begin{array}{l}\text { Metode Penelitian Kualitatif/Lexy J. } \\
\text { Moleong }\end{array}$ \\
\hline & $\begin{array}{l}\text { Metode Penelitian Kuantitatif: komunikasi, } \\
\text { ekonomi, dan kebijakan publik dst/M. } \\
\text { Burhan Bungin }\end{array}$ \\
\hline & $\begin{array}{l}\text { Kepribadian jilid 1: teori klasik dan riset } \\
\text { modern/Howard S. Friedman }\end{array}$ \\
\hline & $\begin{array}{l}\text { Penelitian Kualitatif: komuniasi, ekonomi, } \\
\text { dst/M. Burhan Bungin }\end{array}$ \\
\hline & $\begin{array}{l}\text { Teologi Islam: aliran-aliran sejarah analisa } \\
\text { perbandingan/Harun Nasution }\end{array}$ \\
\hline & $\begin{array}{l}\text { Psikologi Belajar/Abu Ahmadi, Widodo } \\
\text { Supriyono }\end{array}$ \\
\hline & $\begin{array}{l}\text { Sejarah Peradaban Islam II: dirasah } \\
\text { Islamiyah/Badri Yatim }\end{array}$ \\
\hline & $\begin{array}{l}\text { Metode Penelitian Kualitatif: paradigma baru } \\
\text { ilmu komunikasi dst/Deddy Mulyana }\end{array}$ \\
\hline & $\begin{array}{l}\text { Hukum perkawinan Islam di Indonesia: } \\
\text { antara fiqh munakahat dst/Amir Syarifuddin }\end{array}$ \\
\hline
\end{tabular}

Sumber: Perpustakaan UIN Sunan Ampel Surabaya 
Bagian akhir tabel menunjukkan beberapa judul buku koleksi perpustakaan yang populer, atau sering dipinjam oleh mahasiswa. Penting dijelaskan di sini, judul-judul buku tersebut, meskipun sering dipinjam oleh mahasiswa, namun tidak menunjukkan bahwa mereka benar-benar meminati buku tersebut. Sebab, jika diperhatikan, buku-buku tersebut lebih banyak merupakan buku-buku teks kuliah.

Data Peminjaman buku perpustakaan UINSA tiap bulan selama tahun 2017 tercatat bahwa yang tertinggi adalah di bulan Maret, yakni hampir mencapai 25 ribu, sedangkan peminjaman terendah yaitu pada bulan Januari dan di bulanbulan libur kenaikan tingkat yaitu Juli-Agustus. Lebih jelasnya dapat dilihat pada gambar berikut.

Gambar 3. Statistik Peminjaman Perpustakaan UIN Sunan Ampel Tahun 2017

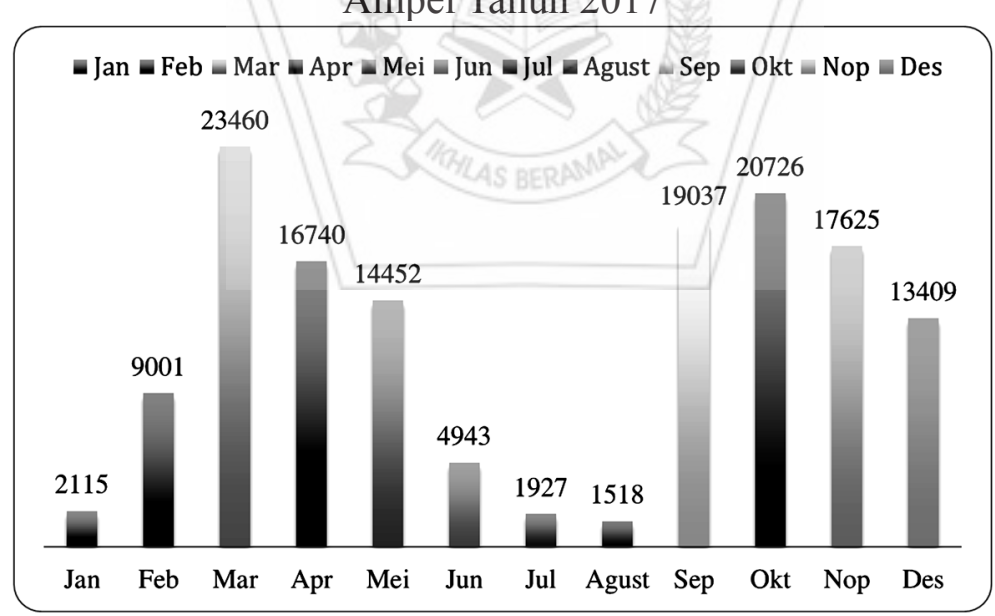

Sumber: Diolah dari data LPJ Perpustakaan UINSA 2017

Adapun kunjungan pemustaka di perpustakaan UINSA dapat dipilah dari beberapa kategori: mahasiswa (S1), dosen, karyawan, dosen luar biasa (tidak tetap), tamu instansi, mahasiswa pascasarjana, serta pengunjung non anggota. 
Sebagaimana pantauan dalam rekap peminjaman pustaka, rekap kunjungan tertinggi ada di bulan September dan Maret yaitu bulan-bulan awal memasuki semester baru. Sedangkan kunjungan terendah adalah di masa libur semester yaitu bulan Januari, Juli, dan Agustus. Selisih kunjungan mahasiswa selama dua tahun tidak terlalu mencolok, meskipun tetap secara umum dapat dikatakan bahwa kunjungan mahasiswa tahun 2017 mengalami peningkatan.

Tabel 11. Statistik Pengunjung Mahasiswa Tahun 2017

Perpustakaan UINSA

\begin{tabular}{cccccccccccc}
\hline Jan & Feb & Mar & Apr & Mei & Jun & Jul & Agu & Sep & Okt & Nop & Des \\
\hline 1897 & 8882 & 23327 & 14330 & 13481 & 4625 & 1524 & 2371 & 25283 & 21777 & 19293 & 14869
\end{tabular}

Sumber: Diolah dari data LPJ Perpustakaan UINSA 2017

Tabel 12. Statistik Pengunjung Mahasiswa Tahun 2016 Perpustakaan UINSA

\begin{tabular}{cccccccccccc}
\hline Jan & Feb & Mar & Apr & Mei & Jun & Jul & Agu & Sep & Okt & Nop & Des \\
\hline 1390 & 1088 & 21163 & 15111 & 12178 & 8174 & 1644 & 2437 & 16077 & 18888 & 18190 & 15986 \\
\hline
\end{tabular}

Sumber: Diolah dari data LPJ Perpustakaan UINSA 2017

Pelayanan perpustakaan UINSA terdiri dari berbagai hal yaitu: layanan sirkulasi, layanan referensi, layanan koleksi khusus, layanan audio visual, layanan nonton bareng, layanan photo copy, layanan bimbingan pemakai, layanan ruang baca, layanan permohonan judul buku, layanan pemesanan buku, layanan kartu sakti, dan book reserve.

1. Layanan Sirkulasi adalah layanan yang diberikan kepada pemustaka (termasuk mahasiswa) untuk memperoleh pinjaman bahan pustaka dan penyelesaian administrasinya.

2. Layanan Referensi adalah layanan dalam bentuk bantuan, petunjuk, atau bimbingan untuk menemukan 
bahan pustaka atau informasi.

3. Layanan Koleksi Khusus yang menyediakan koleksi hasil karya institusi (institutional repository) seperti skripsi, tesis, dan disertasi. Koleksi jenis ini diperlakukan seperti koleksi referensi, yaitu hanya dapat dibaca di tempat dan difotocopy dengan persyaratan khusus. Pemustaka dapat memanfaatkan koleksi khusus dengan penelusuran informasi awal baik melalui katalog digital. Pemustaka bisa mendapatkan infomasi mengenai abstrak, bab-bab tertentu, tahun terbit dan sebagainya, sementara untuk informasi nomor panggil dan bibliografi secara keseluruhan dapat diakses melalui katalog online.

4. Layanan Audio Visual adalah layanan koleksi berbasis teknologi informasi. Layanan yang diberikan meliputi; internet, CD-ROM, televisi, dan VCD/DVD.

5. Layanan Nonton Bareng adalah layanan pemutaran film-film terbaru secara masif yang biasanya ditayangkan pada hari Jumat mulai pukul 08.30. Layanan ini juga memungkinkan pemustaka untuk mengajukan request film sesuai dengan yang diinginkan.

6. Layanan Photo Copy diberikan untuk mempermudah pemustaka memperoleh informasi. Pemustaka dapat mem- photo copy koleksi perpustakaan yang diperlukan. Layanan ini diberikan sebagai solusi pemustaka untuk mendapatkan bahan pustaka yang tidak dipinjamkan, seperti koleksi tandon dan koleksi referensi.

7. Layanan Bimbingan Pemakai adalah kegiatan yang dikemas dalam bentuk orientasi sistem informasi kepada mahasiswa baru UINSA. 
8. Layanan Ruang Baca memberikan kenyamanan kepada pemustaka, Perpustakaan UIN Sunan Ampel melengkapi semua ruangannya dengan meja baca, AC, penerangan yang memadai, dan hubungan internet gratis. Ruang baca didesain berdekatan dengan rak koleksi untuk memudahkan pemustaka dalam memperoleh informasi yang diperlukan.

9. Layanan permohonan Judul Buku. Jika pemustaka memerlukan buku-buku yang belum ada di Perpustakaan UIN Sunan Ampel, maka pemustaka dapat mengajukan permohonan judul buku dengan mengisi formulir online yang tersedia di link yang disediakan di web perpustakaan UINSA.

10. Layanan Pemesanan Buku adalah layanan kepada para pemustaka yang sangat membutuhkan koleksi perpustakaan, sementara koleksi tersebut sedang dipinjam oleh pemustaka lain.

11. Layanan Kartu Sakti merupakan bentuk kerjasama perpustakaan UINSA dengan perpustakaan lain untuk saling mengakses dan memanfaatkan koleksi yang direalisasikan dalam bentuk 'kartu sakti'. Kartu ini dapat dijadikan identitas untuk menggunakan jasa layanan perpustakaan yang tergabung dalam Forum Kerjasama antara Perpustakaan Perguruan Tinggi Negeri (FKP2TN). Perpustakaan UIN Sunan Ampel menjadi bagian dari anggota Forum Kerjasama yang memberikan peluang bagi seluruh anggotanya untuk dapat memanfaatkan fasilitas perpustakan lain yang juga tergabung dalam Forum Kerjasama.

12. Book Reserve atau layanan koleksi tandon adalah layanan koleksi yang memiliki tingkat peminatan cukup tinggi 
serta referensi wajib dari dosen dengan peminjaman terbatas dan hanya berjumlah satu eksemplar. Layanan koleksi tandon mencakup beberapa jenis koleksi, yaitu; a) koleksi buku on reserve, b) koleksi artikel jurnal, c) koleksi artikel koran (kliping), dan koleksi majalah.

Ada beberapa program pendukung literasi yang diadakan oleh perpustakaan UINSA tiap tahun selain pelayanan keseharian terhadap warga UINSA, yakni; 1) Pelatihan bagi mahasiswa baru, 2) Pelatihan penyusunan tugas akhir, 3) Pelatihan e-journal, 4) Perlombaan perpustakaan, 5) Workshop Indeksisasi, 6) Pelatihan Aploud mandiri, dan 7) Bedah buku (Wawancara dengan Umi, 22 Mei 2018).

Pelatihan bagi mahasiswa baru dilakukan sebagai pengenalan perpustakaan. Pelatihan ini menggunakan modul dua jam pelajaran. Pelaksanaan pelatihan ini di tiap bulan September, dan sifatnya wajib. Satu kelas terdiri dari empat puluh orang, dan sesinya dilaksanakan sesuai jumlah mahasiswa baru. Kegiatan yang dikemas dalam bentuk Orientasi Sistem Informasi dilakukan bertujuan untuk; a) mengenalkan mahasiswa tentang pelayanan perpustakaan, seperti: jenis-jenis layanan, cara mendapatkan layanan, cara mencari informasi/ilmu pengetahuan dengan cepat, tepat dan mudah sesuai dengan kebutuhan, b) membiasakan mahasiswa dengan buku-buku referensi dan penunjang mata kuliah serta memberikan instruksi cara penggunaannya, c) memberikan bantuan dalam metode penelusuran sumber-sumber informasi/ ilmu pengetahuan melalui OPAC, CD-ROM, internet, dan alat bantu lainnya yang ada di perpustakaan, dan d) bimbingan pemakai diberikan kepada calon anggota perpustakaan (mahasiswa baru) pada saat orientasi perpustakaan.

Bagi mahasiswa semester akhir (bukan mahasiswa 
baru) terdapat pelatihan penyusunan tugas dan unggah mandiri. Unggah mandiri meliputi cara-cara mengunggah file tugas akhir, scanning, mengubah format word ke pdf, dan seterusnya. Bagi mahasiswa secara umum, terdapat kegiatan pelatihan e-journal, indeksisasi, dan perlombaan yang diselenggarakan perpustakaan. Salah satu contoh perlombaan perpustakaan misalnya yang terakhir ada lomba desain kartu anggota perpustakaan (Wawancara Umi, 22 Mei 2018).

Program selanjutnya yang diperuntukkan untuk umum misalnya adalah bedah buku dan diskusi. Di antaranya pada tahun 2016 dilaporkan kegiatan bedah buku "Islam Nusantara" dan "Islam Berkemajuan". Program ini dilaksanakan dalam rangka mendukung program "Surabaya Berliterasi," yaitu dengan menumbuhkan budaya baca dan budaya akademik khususnya di lingkungan UIN Sunan Ampel dan sebagai strategi pendekatan perpustakaan kepada pemustaka (Perpustakaan UINSA, 2016: 1-4).

Selain perpustakaan, infrastrukur dan peristiwa literasi di UINSA juga terlihat dalam program Kuliah Kerja Nyata (KKN) Literasi. KKN ini dilakukan di Kota Surabaya. Dilakukan selama dua bulan, dan terdapat dua kali KKN Literasi dalam setahun. Sasaran KKN ini adalah madrasah dan perpustakaan masyarakat, tujuannya adalah meningkatkan literasi siswa madrasah dan manajemen perpustakaan.

Asal mula munculnya KKN literasi ini adalah sebagai berikut. USAID pernah menawarkan kerjasama pengembangan mahasiswa (KKN) pada tahun 2013. Setelah lelang (presentasi dari masing-masing LPPM kampus terkait program kerja) terpilihlah UINSA untuk digandeng USAID. Program utamanya ada tiga hal: teaching learning, Manajemen Berbasis Sekolah (MBS), dan Literasi. Program 
KKN literasi yang saat ini sudah berada di angkatan ke-7 ( $2 \mathrm{x}$ setahun). KKN ini memiliki dua program utama: a) pemakaian aplikasi literasi; b) revitalisasi atau manajemen perpustakaan dan KWB (kurikulum wajib baca); c) ABCD (asset base community development). Pilot KKN literasi adalah mahasiswa Fakultas Tarbiyah dan Ilmu Keguruan, yang kemudian juga menjalar ke beberapa fakultas lainnya. Sebelum KKN literasi dilakukan placement test untuk mengukur kepribadian, seperti ekstrovet tidaknya mahasiswa, serta proporsi tim. Sebelum turun KKN, mahasiswa dibimbing dengan pembekalan program literasi selama lima hari. Selama ini sasaran KKN literasi masih menyasar pada madrasah (MI dan MTs) dan baru satu MAN. Madrasah yang diutamakan negeri terlebih dahulu sebagai percontohan. Hingga saat ini baru 50 madrasah di Kota Surabaya yang sudah dijadikan lokasi KKN literasi. Di madrasah, mahasiswa yang ditugasi ada dua atau tiga orang yang bekerjasama dengan guru kelas. Selain madrasah terdapat pula program KKN pendampingan taman baca masyarakat (Wawancara dengan dosen, 17 Mei 2018).

\section{UIN Maulana Malik Ibrahim Malang}

Kondisi infratruktur praktik literasi mahasiswa di UIN Maulana Malik Ibrahim (UIN Malang) yang dapat digambarkan adalah, pertama mengenai perpustakaan. Kedua, beberapa kegiatan yang mendukung praktik literasi mahasiswa. Data tentang perpustakaan pun tentang data di Perpustakaan Pusat UIN Malang.

Perpustakaan Pusat UIN Malang memiliki sejumlah koleksi, yakni koleksi umum, koleksi khusus, referensi, skripsi dan laporan penelitian. Koleksi-koleksi tersebut terdiri 
dari berbagai macam subyek, mulai dari filsafat, agama, ilmu-ilmu sosial, bahasa, ilmu-ilmu murni, ilmu terapan, kesenian, sastra dan geografi umum, sejarah dan cabangnya. Dari beberapa koleksi yang ditelusuri, penemuan terhadap koleksi fiksi justru tidak didapatkan, bahkan menurut laporan statistik Perpustakaan Pusat UIN Malang koleksi fiksi memang tidak ada. Statistik jumlah masing-masing koleksi dapat ditampilkan dalam tabel-tabel berikut.

Tabel 13. Jumlah Koleksi Perpustakaan UIN Maulana Malik Ibrahim

\begin{tabular}{lrr}
\multicolumn{1}{c}{ Tipe Koleksi } & Judul & Eksemplar \\
\hline Umum & 152462 & 152277 \\
\hline Koleksi Khusus & 14894 & 14878 \\
\hline Referensi & 6021 & 6002 \\
\hline Skripsi & 7.337 & 7.337 \\
\hline Laporan Penelitian & 12 & 12 \\
Sumber: Laporan Perpustakaan Pusat UIN Malang &
\end{tabular}

Tabel 14. Jumlah Koleksi Per Kelas/Subyek

\begin{tabular}{|c|c|c|}
\hline \multirow[t]{2}{*}{ Klasifikasi } & \multicolumn{2}{|c|}{ Jumlah Buku } \\
\hline & Judul & Eksp. \\
\hline Karya Umum & 2.514 & 12.153 \\
\hline Filsafat dan disiplin terkait & 2.241 & 11.752 \\
\hline Agama & 23.015 & 70.169 \\
\hline Ilmu-ilmu sosial & 9.057 & 44.286 \\
\hline Bahasa & 2.047 & 12.914 \\
\hline Ilmu-ilmu Murni & 2.418 & 9.554 \\
\hline Ilmu-ilmu terapan & 5.340 & 5.340 \\
\hline Kesenian & 715 & 3.413 \\
\hline
\end{tabular}




\begin{tabular}{lrr}
\hline Sastra & 2.047 & 7.558 \\
\hline Geografi umum dan sejarah serta cabangnya & 1.068 & 1.068 \\
\hline Jumlah Total & 50.934 & 21.0763
\end{tabular}

Sumber: Laporan Perpustakaan Pusat UIN Malang

Jumlah peminjaman koleksi terbanyak di tahun 2017 menunjukkan di bulan-bulan Februari-Maret (masingmasing sejumlah 9076 dan 7907 jumlah peminjaman) dan September-Oktober (10.553 dan 10.272 jumlah peminjaman). Bulan-bulan ini adalah masa-masa di pertengahan semester dan menjelang ujian akhir semester. Biasanya bulanbulan tersebut memang mahasiswa banyak memiliki tugas kuliah, sehingga mahasiswa banyak meminjam buku untuk mengerjakan tugas.

Namun, berdasarkan data statistik kunjungan mahasiswa di Perpustakaan UIN Malang, terjadi penurunan kunjungan di tahun 2017. Jika di tahun 2016 kunjungan mencapai 168.212 kunjungan, maka di tahun 2017 turun sedikit, yakni 167.467. Meskipun demikian, terjadi peningkatan kunjungan secara berturut sejak tahun 2014 hingga 2016. Berikut data statistik jumlah peminjaman di tahun 2017 dan jumlah kunjungan sejak tahun 2014.

Tabel 15. Jumlah Peminjaman Koleksi Perpustakaan Pusat UIN Malang Tahun 2017

\begin{tabular}{llrr}
\hline \multirow{2}{*}{ No. } & \multirow{2}{*}{ Bulan } & \multicolumn{2}{c}{ Tahun } \\
\cline { 3 - 4 } & & $\mathbf{2 0 1 7}$ & $\mathbf{2 0 1 8}$ \\
\hline 1 & Januari & 2086 & 2066 \\
\hline 2 & Februari & 9076 & 8512 \\
\hline 3 & Maret & 7907 & 7131 \\
\hline 4 & April & 5874 & 6057 \\
\hline 5 & Mei & 4782 & 2815 \\
\hline
\end{tabular}




\begin{tabular}{llr}
\hline 6 & Juni & 1460 \\
\hline 7 & Juli & 736 \\
\hline 8 & Agustus & 7808 \\
\hline 9 & September & 10553 \\
\hline 10 & Oktober & 10272 \\
\hline 11 & Nopember & 7298 \\
\hline 12 & Desember & 3743 \\
\hline & Total & 71595 \\
\hline
\end{tabular}

Sumber: Laporan Statistik UIN Maulana Malik Ibrahim

Tabel 16. Jumlah Pengunjung Lima Tahun Terakhir Perpustakaan Pusat UIN Malang

Tahun

Jumlah Pengunjung

\begin{tabular}{rr}
\hline & \\
\hline 2014 & 21.007 \\
\hline 2015 & 12.9916 \\
\hline 2016 & 16.8212 \\
\hline 2017 & 16.7467 \\
\hline 2018 & 62.034 \\
\hline Jumlah Total & 548.636 \\
\hline
\end{tabular}

Sumber: Laporan Statistik UIN Maulana Malik Ibrahim

Selain menyediakan layanan peminjaman koleksi, Perpustakaan Pusat UIN Malang juga menyelenggarakan berbagai kegiatan yang menjadikan peristiwa literasi mahasiswa. Kegiatan-kegiatan tersebut terkait dengan pelatihan penulusuran informasi dan pengetahuan ilmiah serta penulisan akademik. Kegiatan-kegiatan tersebut ada yang diperuntukan untuk mahasiswa $\mathrm{S} 1$ dan ada yang diperuntukan untuk mahasiswa Pascasarjana. Beberapa contoh kegiatan yang dilakukan oleh Perpustakaan adalah sebagai berikut. 
Tabel 17. Kegiatan Pendukung Peristiwa Literasi di Perpustakaan UIN Malang

\begin{tabular}{|c|c|c|}
\hline No & Judul & Peserta \\
\hline 1 & $\begin{array}{l}\text { Menggunakan Turnitin untuk } \\
\text { Meningkatkan Kualitas Akademic Writing }\end{array}$ & $\begin{array}{l}\text { Mahasiswa } \\
\text { Pascasarjana UIN } \\
\text { Malang }\end{array}$ \\
\hline 2 & $\begin{array}{l}\text { Zotero } 5 \text { for Building and Managing Your } \\
\text { Research Library }\end{array}$ & Dosen UIN Malang \\
\hline 3 & $\begin{array}{l}\text { Pelatihan Academic Writing: Developing } \\
\text { Effective Paragraphs }\end{array}$ & Dosen UIN Malang \\
\hline 4 & $\begin{array}{l}\text { Zotero } 5 \text { untuk Membangun dan } \\
\text { Mengembangkan Research Library }\end{array}$ & $\begin{array}{l}\text { Mahasiswa Baru } \\
\text { Pascasarjana UIN } \\
\text { Malang }\end{array}$ \\
\hline 5 & $\begin{array}{l}\text { Mengembangkan Kebijakan Plagiasi } \\
\text { dalam Karya Ilmiah dan Publikasi Ilmiah }\end{array}$ & $\begin{array}{l}\text { Dosen Fak Ekonomi } \\
\text { UIN Malang }\end{array}$ \\
\hline 6 & $\begin{array}{l}\text { Strategi Menelususri Referensi Riset } \\
\text { bIdang Language dan Literatur Melalui } \\
\text { Springer Journalis (link.springer.com) }\end{array}$ & $\begin{array}{l}\text { Mahasiswa Jurusan } \\
\text { Sastra Inggris Fak } \\
\text { Humaniora UIN } \\
\text { Malang }\end{array}$ \\
\hline 7 & $\begin{array}{l}\text { Memanfaatkan Turnitin untuk } \\
\text { Menghindari Plagiasi dalam Karya Ilmiah } \\
\text { dan Publikasi Ilmiah }\end{array}$ & $\begin{array}{l}\text { Mahasiswa Pasca } \\
\text { Sarjana UIN } \\
\text { Maulana Malik } \\
\text { Jbrahim Malang }\end{array}$ \\
\hline 8 & $\begin{array}{l}\text { Menggunakan Zotero } 5 \text { untuk } \\
\text { Membangun dan Mengembnagkan } \\
\text { Reseach Library }\end{array}$ & $\begin{array}{l}\text { Mahasiswa Jurusan } \\
\text { Sastra Inggris UIN } \\
\text { Malang }\end{array}$ \\
\hline 9 & $\begin{array}{l}\text { Sumber-Sumber Referensi Riset Online } \\
\text { (Buku, Skripsi, Jurnal dll) }\end{array}$ & $\begin{array}{l}\text { Mahasiswa Bidik } \\
\text { Misi UIN Malang }\end{array}$ \\
\hline 10 & Zotero 5 untuk Mengelola Referensi Riset & $\begin{array}{l}\text { Mahasiswa Program } \\
\text { Doktor UIN Malang }\end{array}$ \\
\hline 11 & $\begin{array}{l}\text { Pemanfaatana Research Repository, } \\
\text { Turnitin, dan e-journal Springer Link dan } \\
\text { Emerald Insigh }\end{array}$ & $\begin{array}{l}\text { Dosen Tadris } \\
\text { Matematika dan } \\
\text { Bahasa Inggris UIN } \\
\text { Malang }\end{array}$ \\
\hline 12 & $\begin{array}{l}\text { Strategi Memperkaya Referensi dan } \\
\text { Mempertajam Topik Penelitian Pendidikan } \\
\text { Dasar }\end{array}$ & $\begin{array}{l}\text { Mahasiswa Prodi } \\
\text { Magister PGMI Uin } \\
\text { Malang }\end{array}$ \\
\hline
\end{tabular}




\section{UIN Mataram}

Kondisi infrastruktur pendukung peristiwa dan praktik literasi yang dapat digambarkan di UIN Mataram adalah Perpustakaan Pusat Kampus UIN Mataram (Perpustakaan UIN Mataram). Selain di kampus pusat (kampus 1), perpustakaan terdapat juga di kampus 2, meskipun hanya ada di Fakultas Tarbiyah dan Keguruan. Koleksi perpustakaan di Fakultas Tarbiyah dan Keguruan tidak selengkap di perpustakaan pusat, bahkan secara sistem masih terpusat di kampus 1 . Koleksi Perpustakaan Mataram terdiri dari koleksi umum dan koleksi Islam. Koleksi umum terdiri dari karya umum, ilmu filsafat, agama dan ilmu-ilmu sosial, bahasa, ilmu-ilmu murni, ilmu-ilmu terapan (teknologi), kesenian dan olah raga, kesusastraan, serta sejarah dan geografi. Adapun untuk koleksi Islam, terdiri dari Islam umum, Alquran dan ilmuilmu yang membahasanya, hadis dan ilmu-ilmu seputar hadis, filsafat dan ilmu kalam, fikih dan ushul fikih, etika Islam dan tasawuf, sosial budaya Islam, Pendidikan Islam, Aliran-aliran dalam Islam, sejarah dan geografi Islam. Berikut gambaran jumlah koleksi Perpustakaan UIN Mataram.

Tabel 18. Jumlah Judul Buku dan Eksemplar Koleksi Perpustakaan UIN Mataram Per Mei 2018

\begin{tabular}{lccccc}
\hline \multicolumn{3}{c}{ Koleksi Umum } & \multicolumn{3}{c}{ Koleksi Islam } \\
\hline \multicolumn{1}{c}{ Subyek } & Judul & Eksemplar & Subyek & Judul & Eksemplar \\
\hline $\begin{array}{l}\text { Karya } \\
\text { Umum }\end{array}$ & 1767 & 6903 & Islam Umum & 404 & 2153 \\
\hline $\begin{array}{l}\text { Ilmu } \\
\text { Filsafat }\end{array}$ & 2502 & 6239 & $\begin{array}{l}\text { Alquran dan } \\
\text { ilmu-ilmu yang } \\
\text { membahasanya }\end{array}$ & 594 & 3037 \\
\hline Agama & 6567 & 30079 & $\begin{array}{l}\text { Hadis dan ilmu } \\
\text { seputar hadis }\end{array}$ & 330 & 1698 \\
\hline
\end{tabular}




\begin{tabular}{|c|c|c|c|c|c|}
\hline $\begin{array}{l}\text { Ilmu-ilmu } \\
\text { sosial }\end{array}$ & 4480 & 25440 & $\begin{array}{l}\text { Filsafat dan } \\
\text { Ilmu Kalam }\end{array}$ & 338 & 1849 \\
\hline Bahasa & 917 & 3766 & $\begin{array}{l}\text { Fikih dan } \\
\text { Ushul Fikih }\end{array}$ & 1089 & 7744 \\
\hline $\begin{array}{l}\text { Ilmu-ilmu } \\
\text { Murni }\end{array}$ & 851 & 4989 & $\begin{array}{l}\text { Etika Islam dan } \\
\text { Tasawuf }\end{array}$ & 563 & 3126 \\
\hline $\begin{array}{l}\text { Ilmu-ilmu } \\
\text { terapan } \\
\text { (teknologi) }\end{array}$ & 914 & 5829 & $\begin{array}{l}\text { Sosial Budaya } \\
\text { Islam }\end{array}$ & 660 & 4498 \\
\hline $\begin{array}{l}\text { Kesenian } \\
\text { dan Olahraga }\end{array}$ & 191 & 247 & $\begin{array}{l}\text { Pendidikan } \\
\text { Islam }\end{array}$ & 1094 & 7533 \\
\hline Kesusastraan & 374 & 1541 & $\begin{array}{l}\text { Aliran-aliran } \\
\text { dalam Islam }\end{array}$ & 48 & 395 \\
\hline $\begin{array}{l}\text { Sejarah dan } \\
\text { Geografi }\end{array}$ & 366 & & $\begin{array}{l}\text { Sejarah dan } \\
\text { Geografi Islam }\end{array}$ & 301 & 1651 \\
\hline
\end{tabular}

Sumber: Data Statistik Koleksi Perpustakaan UIN Mataram

Jika melihat data statistik peminjaman mahasiswa terhadap koleksi Perpustakaan UIN Mataram, tahun 2017 terjadi peningkatan di banding tahun 2016. Jika tahun 2016 jumlah peminjaman oleh mahasiswa berjumlah 71,474 peminjaman, tahuan 2017 menjadi 82,971 peminjaman. Peminjaman terbanyak terjadi di bulan-bulan pertengahan semester atau akhir semester. Pada tahun 2017, peminjaman terbanyak di bulan Maret dan Oktober. Ini berada pada masamasa pertengahan semester. Menurut Kepala Perpustakaan UIN Mataram, peminjaman koleksi meningkat di tengah semester, terutama di masa-masa banyak tugas kuliah yang diberikan dosen kepada mahasiswa (wawancara dengan Kepala Perpustakaan UIN Mataram, 23 Mei 2018).

Gambar 4. Statistik Jumlah Peminjaman Buku di Perpustakaan UIN Mataram 


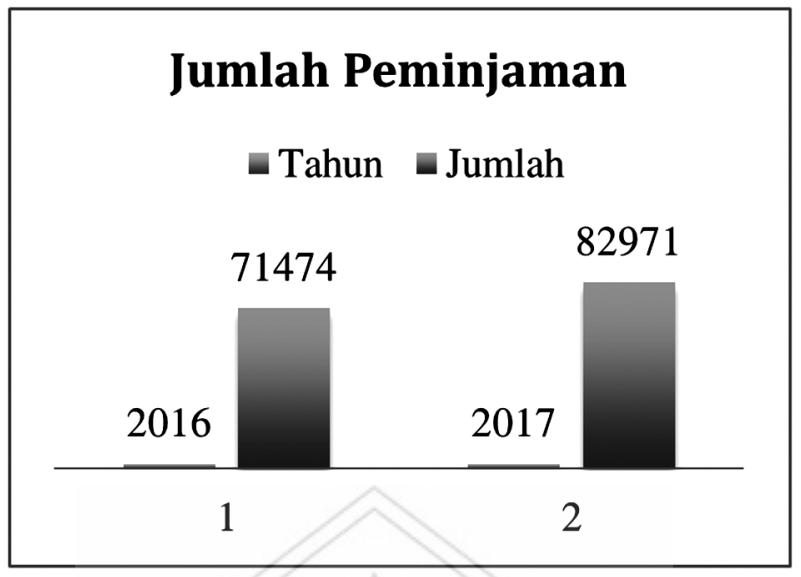

Sumber: Laporan Perpustakaan UIN Mataram

Gambar 5. Statistik Jumlah Peminjaman Buku di

Perpustakaan UIN Mataram

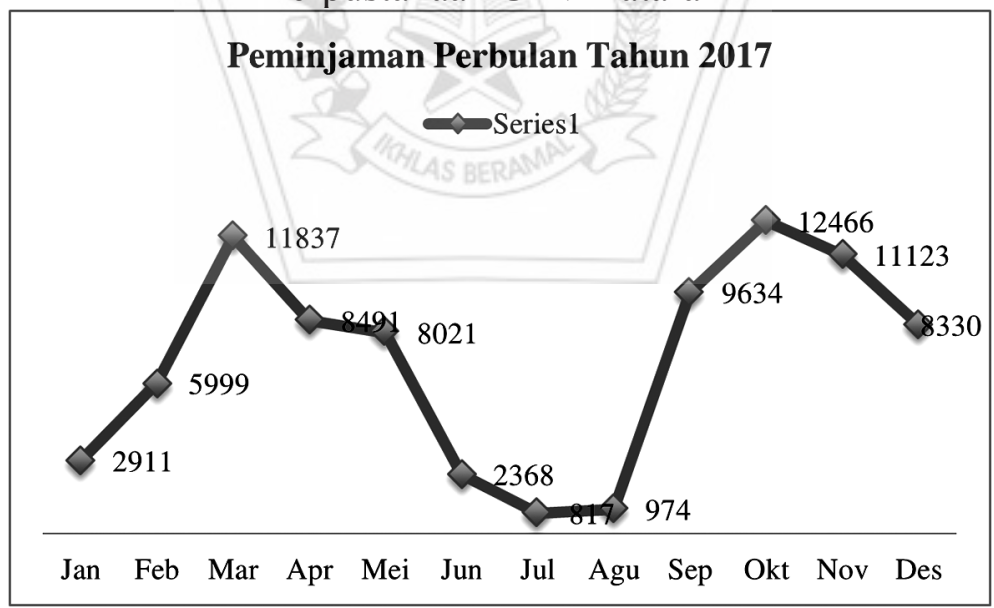

Sumber: Laporan Perpustakaan UIN Mataram

Adapun buku-buku yang banyak dipinjam selama tahun 2017 adalah buku-buku dengan judul sebagai berikut: 
Tabel 19. Judul Buku yang Banyak Dipinjam Selama Tahun 2017

Pendidikan Kewargaan (Civic Education) : Demokrasi Hak Asasi Manusia dan Masyarakat Madani / Dede Rosyada [et. all]

Fiqih Wakaf

Hadits dalam perspektif keilmuan : memposisikan hadits secara proporsional / H. Syamsu Syauqani

Ushul Fiqh / H. Abd. Rahman Dahlan

Bank dan lembaga keuangan syariah / Andri Soemitra

Fiqh Muamalat : Sistem Transaksi dalam Fiqh Islam / Abdul Aziz Muhammad Azzam

Fiqih Muamalah/ Hendi Suhendi

Akhlak Tasawuf / Rosihon Anwar

Fiqh Islam (hukum fiqh lengkap) / Sulaiman Rasjid

Pendidikan Kewargaan (Civic Education) : Demokrasi Hak Asasi

Manusia dan Masyarakat Madani / Dede Rosyada [et. all]

Fiqih Wakaf

Hadits dalam perspektif keilmuan : memposisikan hadits secara proporsional / H. Syamsu Syauqani

Ushul Fiqh / H. Abd. Rahman Dahlan

Bank dan lembaga keuangan syariah / Andri Soemitra

Fiqh Muamalat : Sistem Transaksi dalam Fiqh Islam / Abdul Aziz

Muhammad Azzam

Fiqih Muamalah/ Hendi Suhendi

Akhlak Tasawuf / Rosihon Anwar

Fiqh Islam (hukum fiqh lengkap) / Sulaiman Rasjid

Sumber: Laporan Perpustakaan UIN Mataram

Berdasarkan tabel-tabel di atas, buku-buku yang banyak dipinjam oleh mahasiswa adalah cenderung pada buku-buku teks perkuliahan. Buku teks hukum fikih yang populer di berbagai generasi juga digunakan oleh mahasiswa sebagai rujukan dalam perkuliahan (wawancara dengan mahasiswa Fakultas Syariah dan Hukum, 23 Mei 2018). 
Sebagaimana penuturan Kepala Perpustakaan, kebanyakan mahasiswa meminjam buku-buku yang terkait dengan mata kuliah (wawancara dengan Kepala Perpustakaan UIN Mataram, 25 Mei 2018). Namun, seperti pengakuan seorang mahasiswa, ketidaan buku-buku lain yang terkait dengan ilmu komunikasi di Fakultas Tarbiyah dan Keguruan ataupun Pendidikan IPS misalnya juga bisa memicu keengganan mahasiswa meminjam koleksi dan buku-buku yang tersedia di perpustakaan (wawancara dengan mahasiswi Fakultas Dakwah dan Komunikasi UIN Mataram, 17 Mei 2018).

Selain layanan koleksi tercetak, Perpustakaan UIN Mataram juga menyediakan akses terhadap sumber-sumber rujukan ilmiah baik itu buku maupun jurnal-jurnal online. Namun seperti yang diakui oleh Kepala Perpustakaan (wawancara, 25 Mei 2018), banyak mahasiswa yang belum maksimal menggunakan. Selain karena kurangnya keterampilan dalam mengakses sumber-sumber tersebut, juga keengganan mereka mengunjungi perpustakaan. Selain itu, jaringan yang internet yang buruk, terutama di kampus dua menyebabkan akses terhadap sumber-sumber online ini menjadi terhambat.

Seperti beberapa perpustakaan di kampus UIN yang lain, setiap tahun awal perkuliahan, pihak perpustakaan menyelenggarakan pendidikan kilat bagi pemustaka atau mahasiswa baru. Pendidikan ini meliputi berbagai teknik penelusuran koleksi, peminjaman, dan layanan-layanan lainnya seperti photo copy koleksi. Selain layanan pendidikan pemustaka, sebetulnya para pustakawan juga menyediakan layanan bimbingan bagi mahasiswa yang ingin belajar dalam mengakses sumber-sumber ilmiah online perpustakaan. Hanya saja hal ini belum berjalan secara maksimal. 


\section{UIN Antasari Banjarmasin}

Visi perpustakaan UIN Antasari adalah "Menjadi pusat sumber pengetahuan studi ilmu-ilmu keislaman yang integral dan holistik." Untuk itu, maka Perpustakaan UIN Antasari menyelenggarakan berbagai layanan, yakni layanan peminjaman dan referensi serta photo copy. Perpustakaan UIN Antasari memiliki total koleksi buku sejumlah 17.390 judul buku. Sedangkan koleksi jurnal sejumlah 52 jurnal. Adapun untuk koleksi referensi, Perpustakaan UIN Antasari memiliki 489 judul koleksi referensi. Jika dibandingkan dengan koleksi perpustakaan di kampus UIN yang sudah dideskripsikan di atas, maka UIN Antasari memiliki jumlah eksemplar buku yang paling sedikit.

Untuk data pengunjung dan peminjaman di Perpustakaan UIN Antasari yang didapatkan adalah data di tahun 2018. Berdasarkan data tersebut, hingga bulan Mei 2018, jumlah peminjaman terbanyak terdapat di bulan Februari dan Maret. Hal yang sama juga terjadi dalam jumlah kunjungan. Jumlah kunjungan terbanyak ada di bulan Februari dan Maret. Seperti yang sudah dijelaskan di atas, bulan-bulan tersebut adalah bulan di mana mahasiswa aktif dalam perkuliahan, dan biasanya mereka banyak mendapatkan tugas. Untuk mengerjakan tugas-tugas tersebut, mereka meminjam buku koleksi perpustakaan. Data kunjungan dan peminjaman di Perpustakaan UIN Antasari Banjarmasin dapat ditampilkan sebagai berikut.

Tabel 20. Data Kunjungan Mahasiswa di Perpustakaan UIN Antasari Banjarmasin Tahun 2018 hingga Bulan Mei

\begin{tabular}{lccccc}
\hline \multicolumn{1}{c}{ Fakultas } & Jan & Feb & Mar & Apr & Mei \\
\hline Tarbiyah dan Keguruan & 1907 & 5883 & 7661 & 5478 & 3073 \\
\hline Syariah & 1663 & 2137 & 3691 & 2756 & 1222 \\
\hline
\end{tabular}




\begin{tabular}{lrrrrr}
\hline Ushuluddin dan Humaniora & 548 & 1173 & 1926 & 1698 & 870 \\
\hline Dakwah dan Komunikasi & 190 & 516 & 853 & 582 & 237 \\
\hline Ekonomi dan Bisnis Islam & 536 & 1266 & 1666 & 1042 & 500 \\
\hline
\end{tabular}

Sumber: Laporan Perpustakan UIN Antasari Banjarmasin

Tabel 21. Data Peminjaman Mahasiswa di Perpustakaan

UIN Antasari Banjarmasin Tahun 2018 hingga Bulan April

\begin{tabular}{ccccc}
\hline Bulan & Jan & Feb & Mar & Apr \\
\hline Peminjaman & 5766 & 9067 & 11723 & 8628 \\
\hline
\end{tabular}

Sumber: Laporan Perpustakan UIN Antasari Banjarmasin

\section{Pemanfaatan Perpustakaan: Sebatas Motivasi Ekstrinsik Literasi}

Para ahli perpustakaan menyatakan bahwa, perpustakaan memiliki peran yang siginifikan sebagai faktor ekstrinsik untuk menumbuhkan masyarakat yang literat. Perpustakaan memiliki kontribusi besar untuk membentuk masyarakat informasi yang berpikir kritis dan menjadi pembelajaran seumur hidup (Naibaho, 2007: 8). Haycock (1995: 94) mengemukakan bahwa lembaga pendidikan yang memiliki perpustakaan dan tenaga pustakawan yang berkualitas baik terbukti memiliki siswa yang: (1) memiliki kemampuan membaca yang baik dan dapat mengkomunikasikan gagasan mereka dengan efektif; (2) membaca lebih banyak buku dibandingkan dengan siswa di sekolah yang perpustakaannya kurang berkembang; (3) memiliki kemampuan riset yang baik dan tahu bagaimana cara menggunakan informasi dalam menulis penelitiannya; (4) memiliki kebiasaan belajar yang baik; (5) memiliki pencapaian akademik yang baik, terlihat dari nilai ujian sekolah yang lebih baik dibandingkan dengan siswa di sekolah yang perpustakaannya kurang berkembang.

Perpustakaan di perguruan tinggi pun memiliki peran yang 
penting. Menurut Loius Round Wilson dan Maurice F. Tauber sebagaimana dikutip oleh Alam (2013: 99), perpustakaan perguruan tinggi sebagai perpustakaan akademik akan memberikan peranan secara maksimal jika memenuhi standar sebagai berikut: (1) memiliki sumber-sumber informasi untuk referensi dan penelitian; (2) memiliki staf atau pengelola perpustakaan yang profesional; (3) memiliki kemampuan untuk mengolah koleksi yang dimiliki sehingga siap dimanfaatkan; (4) memiliki peralatan yang ruangan yang cukup representatif; (5) memiliki sinergi dalam memadukan antara kebijakan administratif dan pendidikan; (6) memiliki kerjasama dengan masyarakat luas, baik tingkat regional, nasional maupun internasional; (7) memiliki dukungan dana yang cukup; (8) memiliki program-program yang jelas.

Memperhatikan enam standar tersebut, tidak semua kampus UIN yang diteliti memenuhi standar tersebut. Seperti di UIN Mataram, standar nomor dua (2) belum dapat terpenuhi. Sebagaimana pengakuan Kepala Perpustakaan UIN Mataram, fokus kegiatan perpustakaan belum banyak melakukan pengembangan di bidang/layanan, tetapi baru berupaya melakukan peningkatan kualitas tenaga perpustakaan untuk lebih mengerti tugas dan kompetensi yang harus dimiliki oleh seorang pustakawan, sehingga nantinya dapat merancang kegiatan-kegiatan yang menarik untuk pemustaka (mahasiswa) (wawancara dengan Kepala Perpustakaan UIN Mataran, 20 Mei 2018). Begitu juga dengan gedung dan ruang yang representatif, UIN Mataram masih menempati gedung lama, sementara kebutuhan layanan dan penggunaan gedung perpustakaan meningkat. Jangankan berbicara ruang diskusi di perpustakaan, ruang baca pun masih terbatas. Memang, di beberapa UIN fasilitas gedung 
perpustakaan, seperti UIN Sunan Kalijaga Yogyakarta, UIN Sunan Ampel Surabaya, UIN Walisongo Semarang atau UIN Maulana Malik Ibrahim cukup memadai, tetapi belum juga menampilkan sebagai perpustakaan yang memicu motivasi intrinsik mahasiswa dalam praktik literasi.

Seperti yang telah dikemukakan dalam data, kunjungan mahasiswa ke perpustakaan ternyata meningkat di masa-masa aktif perkuliahan, terutama ketika jadwal ujian pertengahan semester atau ujian akhir semester berlangsung. Itu artinya, kunjungan perpustakaan dan peminjaman koleksinya yang dilakukan mahasiswa lebih disebabkan karena motivasi ekstrinsik, yakni penyelesaian tugas-tugas perkuliahan. Perpustakaan belum dijadikan tempat kunjungan untuk mengakses beragam kebutuhan literasi berdasarkan motivasi intrinsik. Memang, tidak semua pelayanan perpustakaan dapat berjalanan secara optimal, seperti belum terlaksana secara maksimal pendidikan pengguna perpustakaan di kalangan mahasiswa, tetapi rupanya mahasiswa masih memanfaatkan perpustakaan untuk kegiatan literasi yang dimotivasi secara ekstrinsik.

Perpustakaan memang merupakan salah satu faktor ekstrinsik yang penting di sebuah lembaga pendidikan, tetapi jika penggunaannya hanya sebatas karena pemenuhan kebutuhan yang didasari motivasi intrinsik, maka perpustakaan akan tetap menjadi semacam "etalase" yang tidak dapat menghidupkan ruh praktik literasi dalam diri mahasiswa. Diperlukan sebuah cara untuk menyinergikan agenda-agenda atau kegiatan-kegiatan perpustakaan dengan kegiatan-kegiatan literasi yang lebih menyenangkan agar pemustaka menjadi semakin tertarik untuk mengunjungi perpustakaan. 
Perpustakaan juga belum maksimal disinergikan dalam proses pembelajaran, sehingga belum mengubah kesadaran internal mahasiswa tentang arti penting perpustakaan. Telaah kurikulum yang dilakukan tim peneliti menunjukkan belum ada mata kuliah tentang literasi informasi. Hal tersebut penting sebab salah satu fungsi utama perpustakaan perguruan tinggi adalah mengembangkan keterampilan literasi informasi (Harliansyah, 2016: 1). Literasi informasi sendiri berarti kemampuan mendefinisikan kebutuhan dan ruang lingkup informasi yang dibutuhkan, mampu melakukan penelusuran informasi secara efektif, mampu mengenali dan memilih sumber-sumber informasi yang beragam, mampu menyeleksi dan mengevaluasi informasi yang berkualitas, otoritasi dan layak dijadikan rujukan, mampu menggunakan saran dan media untuk mengelola, mengorganisasikan dan mengkomunikasikan informasi, sadar terhadap isu-isu bias dan reliabilitas informasi dan strategi mengatasinya, mampu secara efektif mentransfer dan mengkomunikasikan informasi melalui berbagai sarana dan media (Harliansyah, 2016: 3).

Integrasi literasi informasi dalam pembelajaran telah diterapkan beberapa negara maju, misalnya di Amerika Serikat, literasi informasi banyak diakomodasi sebagai komponen pembelajaran (Alam, 2013: 101). Pembelajaran literasi informasi dapat membuka kesadaran mahasiswa tentang pentingnya perpustakaan yang tidak hanya sekadar sarana pemenuhan tugas (motivasi ekstrinsik), tetapi sarana pemenuhan informasi dan pengetahuan sepanjang hayat.

\section{Akses IImu Pengetahuan Melalui Media Online Berbasis Universitas}

Aspek yang tampak kurang diperhatikan oleh beberapa 
UIN dan lembaga perpustakaannya adalah mengenai akses ilmu pengetahuan melalui media daring (dalam jaringan) atau online. Media daring ini bukan sekadar menyediakan sumbersumber informasi dan pengetahuan dalam artikel di berbagai jurnal ilmiah di dunia, sebagaimana yang sudah banyak dilakukan oleh layanan perpustakaan. Itu pun nyatanya, juga tidak memantik praktik literasi mahasiswa.

Kehadiran media daring dengan jejaring media sosial yang tumbuh, tidak hanya mengancam keberadaan media cetak, juga memunculkan otoritas-otoritas pengetahuan baru di luar institusi penelitian dan lembaga pendidikan tinggi. Kehadiran media online, selain menyaingi otoritas media cetak, juga otoritas lembaga penelitian dan kampus melalui berbagai saluran pengetahuan. Media daring, meskipun terlihat dangkal, mengubah cara orang mengonsumsi pengetahuan. Inilah yang kemudian menumbuhkan berbagai media online baru yang memberikan informasi dan pengetahuan secara bebas selain yang sudah dikenal detik.com, seperti Tirto, Beritagar, Indoprogres, Mojok, Geotimes, Qureta, dan Alif. Media-media ini tumbuh dengan pembacanya masing-masing. Media sosial (Whatshapp misalnya) sebagai jaringan yang menghubungkan dan bertinteraksi, menambah daya sebar media-media daring secara cepat. Informasi dan pengetahuan masuk ke dalam ruang-ruang privat, seperti Whatshapp, Line dan Facebook (Akmaliah, 2018: 48).

Masifnya akses pengetahuan dan informasi di kalangan mahasiswa parstisipan ditunjukkan dengan data berikut. Para partisipan penelitian (28\% dari 1007) menyatakan satu hingga tiga kali dalam seminggu mengakses informasi keagamaan melalui internet atau media online, ada juga yang mengakses setiap hari (27\%). Sedangkan selebihnya mereka mengakses 
informasi keagamaan satu kali dalam seminggu (17\%), satu kali hingga 3 kali dalam sebulan (14\%), hingga tidak pernah (5\%). Hal ini sebagaimana hasil penelitian Alvara Institute yang menemukan bahwa 85,2 \% milenial menggunakan gawai untuk media sosial (Ali dan Purwandi, 2017: 65).

Beberapa kampus di luar negeri beradaptasi dengan situasi dan kehadiran media daring tersebut, meskipun sudah ada yang berjalan sebelum beberapa media daring yang populer muncul. Misalnya, Australian National University (ANU) membuat www.newmandala.org., yang berisi konten-konten isu-isu terkini dalam studi sosial dan politik di Asia Tenggara. Selain itu, University of Melbourne meluncurkan situs www. indonesiaatmelbourne.unimelb.edu.au yang menyajikan konten-konten sosial, politik dan ekonomi Indonesia. Institusi yang memiliki otoritas pengetahuan, seperti perguruan tinggi dan lembaga penelitian di Indonesia terbilang lambat merespon perkembangan mediasi ilmu pengetahuan di dunia digital dewasa ini. Akibatnya muncul individu-individu baru tanpa afiliasi dengan institusi ilmu pengetahuan ternama yang menyebarkan berbagai pengetahuan-pengetahuan yang lebih mudah dan cepat diakses oleh anak muda generasi milenial, termasuk mahasiswa.

Beberapa sarjana dari kajian Islam mumpuni telah muncul untuk ikut menyebarkan pengetahuan meskipun tanpa afiliasi dengan institusi pengetahuan manapun, seperti Nadirsyah Hosen dengan web-nya www.nadirhosen.net yang lebih menyajikan konten-konten kajian Islam. Teknologi informasi sedang mengarah, bahkan sudah berada di masa dunia digital, anak-anak zaman sekarang juga sudah berada di masa tersebut, jika hal ini tidak diadaptasi, institusi pengetahuan akan ditinggalkan generasi milenial (Akmaliah, 2018: 51). 
Selain secara individual, produksi pengetahuan berbasis media online telah dilakukan oleh beberapa website kepenulisan di Indonesia, salah satunya yakni Qureta yang tujuannya adalah merawat dan mengembangkan tradisi literasi di Indonesia. Website Qureta ini kemudian menginisasi berdirinya Kuliah Qureta. Kuliah Qureta menurut penggagasnya adalah sebuah platform pendidikan yang menyediakan materi-materi perkuliahan dari berbagai cabang ilmu pengetahuan. Kuliah Qureta didesain sebagai alternatif pendidikan tinggi untuk zaman yang tengah berubah, yakni zaman digital. Oleh karena, Kuliah Qureta memberikan kuliah-kuliah berbagai materi atau topik yang relevan dan sedang banyak diperbincangkan agar lebih dapat dipahami secara mendalam.

Gambar 6. Tampilan Website Kuliah Qureta

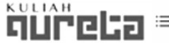

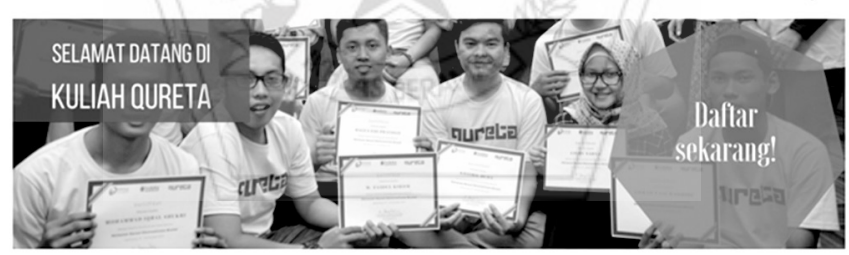

Para Pengajar

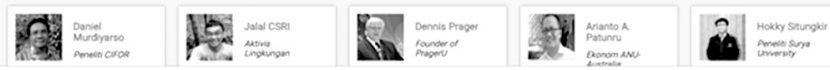

Sumber: Koleksi peneliti (Agus Iswanto)

Sekarang ini, ada banyak cara yang didukung teknologi untuk mengakses ilmu pengetahuan. Salah satunya metode yang dikenal dengan Massive Open Online Course (MOOC). Ada juga akses kuliah online melalui IndonesiaX.co.id. IndonesiaX adalah platform online pendidikan yang menawarkan kursus-kursus online (MOOC) dari universitas, institusi dan praktisi di berbagai bidang untuk mencerdaskan 
bangsa. Selain mudah mengakses, tentu saja tidak dipungut biaya. Sehingga lebih meningkatkan preferensi orang untuk terus mengakses ilmu pengetahuan secara online. Kuliah Kureta, MOOC dan IndonesiaX.co.id seolah akan menjadi "banjir bandang" bagi dunia pendidikan tinggi dalam waktu yang tidak terlalu lama lagi. Apalagi, kini banyak perguruan tinggi di dunia semakin banyak memberikan mata kuliah dengan memanfaatkan teknologi internet yang tengah berkembang pesat (Kasali, 2018: 230-231).

Gambar 7. Tampilan laman IndonesiaX

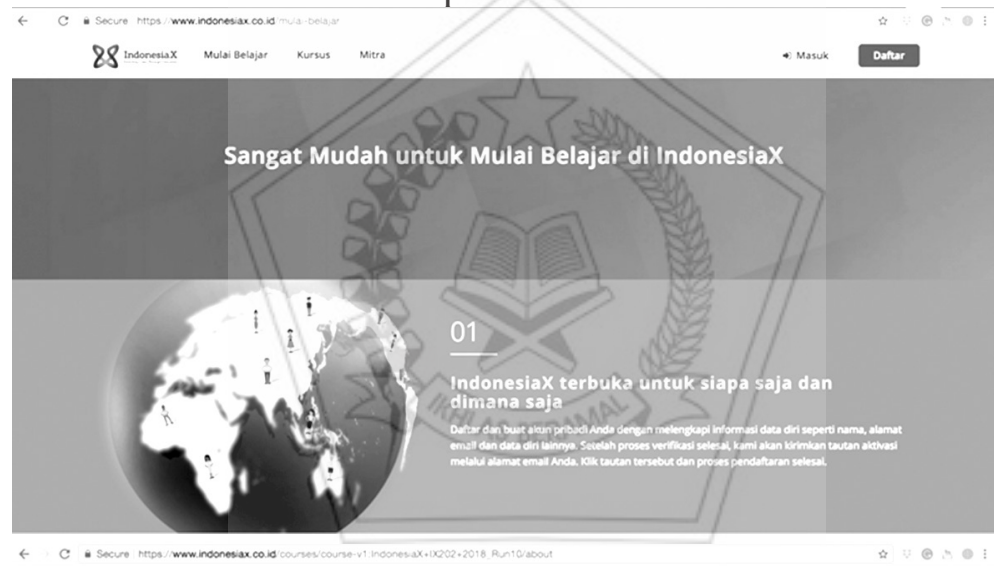

88 insonestix ousbor xurrou

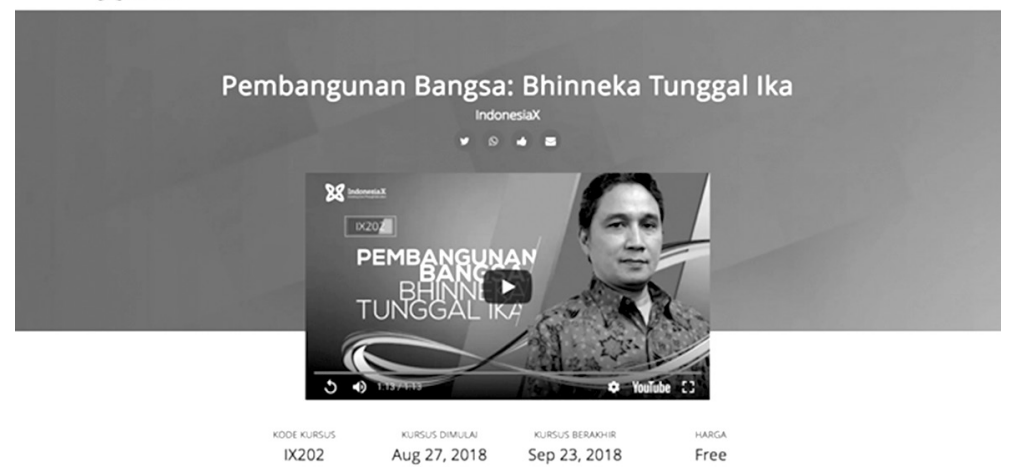

Sumber: Koleksi peneliti (Agus Iswanto) 
Demikian perkembangan produksi ilmu pengetahuan yang ditangkap oleh beberapa orang hingga menjadi tampil menjadi lebih menarik. Mencermati perkembangan ini, ada baiknya kampus-kampus UIN mengambil sisi positif dari perkembangan ini. Dengan otoritas keilmuan yang dimiliki lembaga pendidikan UIN, seharusnya produksi ilmu pengetahuan melalui perangkat teknologi informasi menjadi lebih memperkuat otoritasnya, karena dengan sendirinya akan mendapat tempat di tengah mahasiswa generasi milenial. Produksi ilmu pengetahuan melalui media online belum menjadi infrastruktur yang tersedia di berbagai kampus yang diteliti. Keterbatasan sumber daya dan kesadaran pentingnya adaptasi teknologi menjadi di antara yang menyebabkan.

UIN dengan paradigma dialog dan integrasi antar ilmu pengetahuan sudah semestinya mengaplikasikan paradigma tersebut dalam dunia multiliterasi. Dialog dan integrasi ilmu pengetahuan sekarang ini bukan hanya terbatas pada dialog dan integrasi antar bidang ilmu pengetahuan, tetapi juga dalam hal media yang menjadi wadah ilmu pengetahuan tersebut. Produk ilmu pengethauan dalam bingkai dan integrasi keilmuan seharusnya juga diintegrasikan dalam wadah literasi multimodal, sehingga kampus dapat lebih berperan sebagai agen perubahan masyarakat di tengah perubahan dunia yang memasuki perkembangan teknologi digital. Kampus harus menyediakan akses ilmu pengetahuan di berbagai bidang (multiliterasi) dalam beragam media (multimodal).

Teknologi informasi bisa membuat pendidikan semakin dapat dinikmati oleh banyak orang. Namun, justru karena sifatnya yang serba instan, kemampuan yang dimiliki pun serba instan, tidak mendalam (Kasali, 2018: 226). Untuk mengurangi gap tersebut, perguruan tinggi, dalam hal ini 
UIN, dapat masuk dengan tetap menekankan pada otoritas dan kedalaman pengetahuan seraya menyelaraskan dengan perkembangan teknologi informasi terkini. 


\section{BAB IV \\ MEMPRAKTIKKAN LITERASI}

-Literacy is a bridge from misery to hope. It is a tool for daily life in modern society. It is a bulwark against poverty, and a building block of development, an essential complement to investments in roads, dams, clinics and factories. Literacy is a platform for democratization, and a vehicle for the promotion of cultural and national identity. Especially for girls and women, it is an agent of family health and nutrition. For everyone, everywhere, literacy is, along with education in general, a basic human right.... Literacy is, finally, the road to human progress and the means through which every man, woman and child can realize his or her full potential." (Kofi Annan, Sekjen PBB tahun 1997-2006)

-Literasi adalah jembatan dari kesengsaraan menuju harapan. Literasi adalah alat untuk kehidupan sehari-hari dalam masyarakat modern. Ia adalah benteng melawan kemiskinan, dan blok pembangunan, pelengkap yang penting untuk investasi di jalan, bendungan, klinik dan pabrik. Literasi adalah platform untuk demokratisasi, dan wahana untuk mempromosikan identitas budaya dan nasional. Khusus untuk anak gadis dan wanita dewasa, literasi adalah agen kesehatan dan gizi keluarga. Untuk semua orang, di mana saja, literasi adalah, bersama dengan pendidikan pada umumnya, adalah hak asasi manusia yang mendasar.... Literasi adalah, akhirnya, suatu jalan menuju kemajuan manusia dan sarana setiap pria, wanita dan 
anak-anak untuk dapat menyadari potensi penuhnya." (Kofi Annan, Sekjen PBB tahun 1997-2006)

-Ini Budi. Ini Bapak Budi. Ini kakak Budi.” (Memori pelajaran membaca Bahasa Indonesia)

Kutipan Sekjen PBB tahun 1997-2006, Kofi Annan, menunjukkan bahwa literasi seperti -mantra" mujarab yang mampu menyelesaikan segala persoalan. Apapun masalahnya dalam kehidupan manusia, literasi menjadi kunci. Literasi semakna dengan segala pengetahuan dan keterampilan yang dibutuhkan manusia untuk menyelesaikan persoalan hidupnya secara berkualitas. Dengan -mantra literasi" sejumlah proyek diluncurkan, standardisasi kualitas literasi dilakukan di berbagai bangsa dan negara. Padahal, kalau literasi adalah hak asasi manusia - seperti yang diujarkan Kofi Annan - maka beragamnya warna lokal dalam literasi menjadi niscaya. -Warna lokal" itu bukan hanya berarti dalam pengertian indigeneous literacy (Souza, 2015: 175), tetapi juga mengakui kekhasan kualitas literasi di masingmasing individu atau mahasiswa dalam konteks pembelajaran maupun praktik kehidupan. Karena itu, kajian literasi bukan hanya soal ukuran-ukuran pencapaian skor literasi yang bebas nilai, tetapi literasi menyangkut sikap, pandangan, peristiwa yang menunjukkan praktik literasi.

Karena itu pula, literasi bukan hanya -pembelajaran membaca" seperti dalam memori pembelajaran mengeja bahasa Indonesia: -ini Budi, ini bapak Budi, ini Ibu Budi, ini kakak Budi." Literasi bukan sekadar -melek aksara," karena literasi saat ini tidak lagi bermakna sebagai pemberantasan buta aksara, namun sebuah praktik sosial yang melibatkan kegiatan berbicara, menulis, membaca, menyimak dalam proses memproduksi ide dan mengkonstruksi makna dalam konteks budaya yang spesifik. Dengan demikian, 
sebagaimana dikatakan oleh Dewayani (2017: 12), menjadi literat bermakna bahwa seseorang, termasuk mahasiswa, mampu menggunakan potensinya untuk berpartisipasi secara optimal dalam komunitas dan lingkungan sosialnya. Dalam berpartisipasi tersebut, seseorang dapat mengartikulasikan pendapat dengan bahasa verbal, baik dengan bentuk lisan atau oral, tulisan maupun visual.

$\mathrm{Bab}$ ini menyajikan pembahasan tentang praktik literasi mahasiswa sebagai bentuk upaya memetakan potensi-potensi yang dimiliki mereka. Potensi-potensi ini pada akhirnya akan menjadi bahan refleksi dan rumusan kebijakan tentang praktik literasi di kalangan mahasiswa yang memampukan mereka untuk hidup dalam lingkungan sosialnya. Pemetaan potensi ini bermula dari soal sikap terhadap literasi, perwujudannya dalam perilaku, motivasi-motivasi yang mengarahkan praktik literasi dan bukti-bukti (produk atau artefak) literasi. Uraian tentang literasi di sini difokuskan pada literasi membaca dan menulis secara umum, tidak dibatasi pada bidang atau teks tertentu.

\section{Sikap terhadap Membaca dan Menulis}

Seorang partisipan penelitian mengatakan bahwa "sebenarnya banyak teman-teman saya yang semangat mencari informasi, apalagi sekarang mereka pegang handphone semua, mereka sebenarnya senang membaca" (Wawancara dengan Nurma, 25 Mei 2018). Beberapa kesempatan wawancara secara personal maupun ketika diskusi terfokus, para partisipan mengatakan bahwa sebenarnya "membaca itu penting," baik untuk kepentingan belajar maupun untuk keperluan dalam menjani kehidupan yang lebih luas di masyarakat maupun tempat kerja. Hal ini 
menandakan bahwa sesungguhnya mereka memiliki sikap positif terhadap literasi membaca.

Ketika para partisiapan ditanya "apakah membaca itu penting", hampir semua (98 \%) menjawab bahwa membaca itu penting. Mereka juga setuju jika membaca dapat membantu untuk menemukan sesuatu yang ingin mereka ketahui. Kebanyakan mereka juga (90\%) berpandangan bahwa keahlian yang harus dimiliki dalam hidup. Bahkan mereka (98\%) menyatakan senang ketika membaca. Bahkan mereka kebanyakan $(80 \%)$ tidak setuju bahwa membaca itu susah dan membosanknan. Jawaban-jawaban ini sebetulnya menegaskan bahwa mereka memiliki sikap yang positif terhadap literasi membaca.

Hal yang sama juga terjadi pada sikap literasi menulis. Separuh jumlah partisipan dari seluruh kampus yang diteliti mengatakan bahwa mereka senang menulis. Namun ketika ditanya apakah menulis itu susah, mereka terbagi dua secara merata, sebagian mengatakan bahwa menulis itu susah, sebagian lagi mengatakan bahwa menulis tidak susah. Mereka juga sadar bahwa menulis dapat menjadi media ekspresi ide-ide mereka. Namun, justru yang banyak menjadi halangan mereka ketika menulis adalah menemukan ide, lalu menuliskan dalam kalimat dan terakhir susahnya mencari referensi. Data ini juga menunjukkan bahwa mereka cenderung memiliki sikap yang positif terhadap literasi menulis.

Sikap yang postif terhadap literasi membaca dan menulis penting dikemukakan sebelum menilai perilaku literasi mahasiswa. Sikap positif ini menunjukkan kesadaran mereka terhadap pentingnya membaca dan menulis dalam kehidupan mereka. Seorang partisipan mengatakan bahwa "menulis 
adalah cara meluapkan emosi dan pikiran yang menumpuk" (Wawancara dengan Yenita, 25 Mei 2018). Hal ini dapat dipahami sebab pada masa usia mereka, banyak hal yang bisa dituangkan baik ide maupun emosi ke dalam tulisan. Media untuk meluapkan emosi dan pikiran ini sejalan dengan salah satu problem personal anak muda generasi milenial, yakni merasa kesepian (feeling lonely). Perasaan kesepian berbeda dengan kesendirian. Kesepian adalah sebuah persepsi bahwa seseorang tidak memiliki teman dekat atau lingkungan sosial yang mendukung dirinya, walaupun kenyataannya mereka banyak memiliki teman di lingkungan sehari-sehari (Faisal, 2017: 113). Hal ini mudah dipahami jika memperhatikan beragam curhat (curahan hati) yang sering kali muncul di beberapa media sosial yang mereka miliki. Selain karena mereka suka berbagi mengenai apapun yang terjadi dengan diri mereka, juga karena merasa kesepian.

Menurut Thurtone sebagaimana dikutip oleh Hamalik (2004: 214), sikap merupakan tingkat afeksi yang positif atau negatif yang dihubungkan dengan objek psikologis. Sedangkan objek psikologis itu sendiri adalah simbol, kalimat, slogan, orang, institusi serta ide yang ditujukan agar orang dapat membedakan pengaruh yang positif dan negatif. Sedangkan Taylor, Peplau dan Sears (2009: 165) mengartikan sikap sebagai evaluasi terhadap objek, isu atau orang. Sikap didasarkan pada informasi afektif, behaviorial dan kognitif. Komponen afektif terdiri dari emosi atau perasaan seseorang terhadap suatu stimulus, khususnya evaluasi positif atau negatif. Sedangkan komponen behaviorial adalah cara orang bertindak dalam merespons stimulus. Adapun komponen kognitif terdiri dari pemikiran seseorang tentang objek tertentu, seperti fakta, pengetahuan dan keyakinan. 
Sikap postif dengan demikian menunjukkan komponen afektif dan kognitif terhadap literasi membaca dan menulis. Sikap evaluatif yang positif ini cenderung sederhana atau menyederhanakan kompleksitas komponen kognitif dalam sikap, tetapi menurut Taylor, Peplau dan Sears (2009: 166) sikap afektif yang evaluatif cenderung konsisten.

Sikap mahasiswa terhadap membaca, juga menulis, adalah faktor utama yang mempengaruhi praktik membaca dan menulis. Oleh karena itu sikap yang positif dapat membantu meningkatkan kapasitas literasi membaca dan menulis mahasiswa. Hal ini ditunjukkan oleh hasil penelitian Lindsey Seitz (2010). Berdasarkan hasil wawancaranya, dia menemukan bahwa mahasiswa memiliki sikap yang positif terhadap membaca dapat menunjang kualitas membaca mahasiswa. Hal ini juga berlaku dalam lingkup proses belajar. Banyak pendidik dan peneliti mempertimbangkan sikap postif terhadap belajar dan membaca menjadi faktor penting dalam semua pembelajaran. Siswa atau mahasiswa yang tidak menikmati teks pembelajaran di sekolah atau di kampus misalnya, sering kali tidak tertarik untuk terlibat dalam kegiatan membaca, dan ini dapat terus berlaku seumur hidup (Seitz, 2010: 31). Strickland dan Walker (2004) sebagaimana dikutip oleh Schmitt (2009: 3) menyatakan bahwa masalah sikap adalah bahan yang paling penting dalam pengajaran literasi.

Sikap positif terhadap membaca dan menulis yang ditunjukkan oleh partisipan menjadi penting, karena menurut hasil penelitian Askov dan Fishbach (1973) sebagaimana dikutip oleh Schmitt (2009: 3), sikap yang positif terhadap membaca dapat juga meningkatkan prestasi belajar siswa. Karena itu program-program yang meningkatkan sikap yang 
positif terhadap membaca harus ditingkatkan. Programprogram yang meningkatkan sikap yang positif terhadap membaca selanjutnya akan mendorong perilaku literatmembaca dan menulis-mahasiswa.

\section{Perilaku Membaca dan Menulis}

Kenyataannya, sikap tidak selalu berhubungan dengan perilaku. Dalam banyak kasus, perilaku tidak selalu lahir dari sikap (Taylor, Peplau dan Sears, 2009: 199). Meskipun dalam studi-studi belakangan menemukan adanya konsistensi antara sikap dengan perilaku, itu sifatnya situasional, tergantung berbagai macam situasi. Setiap kali seseorang melakukan perilaku literasi yang jelas, mereka dapat dipengaruhi oleh sikap dan situasi di sekitar, inilah yag kemudian oleh Barton dan Hamilton (2000: 13) sebagai situated literacies (literasiliterasi yang tersituasikan).

Terkait dengan situasi literasi ini, dalam konteks perilaku literasi yang dipraktikan oleh mahasiswa UIN, penting mempertimbangkan pandangan Anne Dyson (1997: 105-110) tentang situasi pembelajaran yang disebut dengan "arena resmi" (official site) dan "arena tidak resmi" (unofficial site). Dyson menggunakan konsep ini untuk kegiatan di ruang kelas. Arena resmi adalah kegiatan belajar formal yang diikuti serangkaian ekspektasi dan observasi terhadap capaian seseorang, ditandai dengan struktur kegiatan yang ditentukan-atau dibatasi oleh kurikulum dan rencana pembelajaran. Adapun arena tidak resmi adalah interaksiinteraksi sosial dalam rangka pembelajaran yang tidak diikat oleh norma-norma pembelajaran seperti kurikulum dan rencana pembelajaran. Biasanya lembaga-lembaga pendidikan formal membagi secara tegas arena resmi dan 
tidak resmi ini.

Namun hal ini bisa dikembangkan pada proses pembelajaran dan perilaku literasi secara umum. Dalam konteks UIN, dapat dikatakan arena resmi ini adalah seluruh kurikulum dan rencana perkuliahan yang diterapkan di kelas sebagai implementasi dari filosofi keilmuan yang integratif. "Arena resmi" perkuliahan tercantum dalam serangkaian daftar mata kuliah yang harus diambil atau didapatkan oleh mahasiswa. Meskipun ada mata kuliah pilihan-di mana mahasiswa boleh tidak mengambil-namun yang lebih banyak merupakan mata kuliah yang wajib diambil sesuai dengan target perkuliahan. Pembelajaran mata kuliah-mata kuliah ini tentu saja merupakan wujud perilaku praktik literasi yang resmi. Sedangkan di luar mata kuliah, bukan merupakan "arena praktik literasi yang resmi."

Identifikasi tersebutsebetulnya dapatlebih disederhanakan dengan mengatakan bahwa perilaku literasi mahasiswa dapat dikategorikan menjadi dua. Pertama, perilaku literasi yang terkait dengan perkuliahan. Kedua, perilaku literasi yang tidak secara langsung terkait dengan perkuliahan tetapi diperlukan dan disenangi oleh mahasiswa.

\section{Tujuan membaca: "membaca untuk belajar dan membaca untuk kesenangan"}

Oleh karena itu, dapat dikatakan bahwa mahasiswa sesungguhnya telah melakukan praktik literasi, sebab seharisehari mereka harus berjibaku dengan teks-teks pelajaran atau perkuliahan yang diberikan oleh dosen. Mereka harus mengerjakan tugas, baik berupa makalah, ringkasan atau review buku maupun peta konsep yang harus dipresentasikan di hadapan teman-teman mereka di kelas dan dosen. Belum 
lagi, bagi mahasiswa yang aktif di berbagai kegiatan yang amat dekat dengan aktivitas literasi, seperti Lembaga Pers Mahasiswa, tentu akan lebih banyak mempraktikan literasi membaca dan menulis. Di sini kemudian penting mengidentifikasi antara "membaca untuk belajar atau tugas" dan "membaca untuk kesenangan."

Mahasiswa sudah menunjukkan perilaku membaca untuk belajar/tugas. Hal ini terlihat dari aktivitas perkuliahan yang banyak melibatkan teks. Berdasarkan wawancara yang dilakukan, dalam masa perkuliahan, mereka membaca sumber referensi rujukan topik perkuliahan, menulis makalah tentang suatu topik yang ditentukan oleh dosen, mereview sebuah buku atau bagian dari buku, membuat peta konsep dari sub bahasan tertentu hingga mempresentasikan hasil bacaan dan karya tulis yang telah mereka buat di depan kelas dalam suatu kelompok diskusi.

Seperti yang banyak diakui oleh partisipan bahwa mereka akan lebih banyak membaca jika: (1) perpustakaan kampus lebih baik fasilitas dan koleksinya (84\% partisipan); (2) dosen mendorong mereka membaca (62\% partisipan); (3) keluarga mendorong mereka untuk membaca (63\%); (4) teman yang mendorong mereka untuk lebih banyak membaca (62\%). Untuk situasi pertama terkait dengan situasi atau dukungan infrastruktur yang mendorong mereka lebih banyak membaca, sementara yang kedua hingga keempat lebih pada dukungan dari orang-orang terdekat.

Untuk fasilitas perpustakaan, beberapa partisipan yang diwawancari mengaku kesulitan mendapatkan koleksi buku-buku terbaru baik yang ada kaitannya dengan kuliah maupun yang tidak. Karena itu, dapat dipahami jika mereka kebanyakan (48, $96 \%$ dari 1007 partisipan) hanya sekali 
mengunjungi perpustakaan dalam waktu satu minggu, bahkan ada (sebanyak 15,89\% partisipan) yang tidak pernah sama sekali mengunjungi perpustakaan dalam waktu seminggu. Hanya 4,87 \% yang setiap hari mengunjungi perpustakaan. Meskipun demikian, kebanyakan mereka memandang perpustakaan nyaman untuk membaca. Selain itu, di perpustakaan partisipan tidak hanya membaca dan meminjam buku, tetapi juga mengerjakan tugas dan mengakses internet gratis. Dengan pandangan-pandangan seperti ini, menjadi dapat dipahami bahwa bagi mereka perpustakaan adalah salah satu infrastuktur yang mendorong mereka untuk lebih giat membaca.

Perilaku yang menunjukkan literasi membaca dapat dilihat dari kemelekatan partisipan pada teks yang dibaca. Banyak partisipan yang ditanya judul buku atau judul artikel apa yang paling berkesan, partisipan kebingungan. Mereka mengatakan tidak mengingat judul buku atau artikel apa yang dibaca. Hal yang terpenting bagi mereka adalah mendapatkan "sesuatu" dari yang dibacanya itu, baik sesuatu itu berupa informasi atau pengetahuan ilmiah. Jelas, ini adalah implikasi dari tahapan membaca untuk belajar/tugas bukan membaca untuk kesenangan.

Membaca untuk belajar/tugas mengimplikasikan suatu "paksaan", suatu motivasi ekstrinsik yang mendorong mahasiswa untuk membaca. Membaca dalam arena resmi perkuliahan tidak menjadi kegiatan yang rekreatif, namun kegiatan yang mekanistik dan terukur. Karena itu, meskipun kegiatan membaca selalu digalakan mulai dari tingkat sekolah hingga kuliah, namun tetap saja tidak menumbuhkan gairah membaca. Teks yang dibaca bukan merupakan bacaan yang dibaca dengan penuh minat. Buku teks perkuliahan tidak lagi 
menumbuhkan minat baca. Kampus dan sekolah bukan tempat buku-buku atau bacaan yang menyenangkan. Terbukti dari pengakuan seorang mahasiswa di UIN Mataram menyatakan bahwa perpustakaan kampus tidak banyak menyediakan buku-buku cerita yang menyenangkan (wawancara dengan Zaidan, 27 Mei 2018). Bacaan-bacaan yang tersedia lebih banyak merupakan bacaan-bacaan yang membosankan untuk tujuan perkuliahan belaka. Hal tersebut terkonfirmasi dari banyaknya pernyataan mahasiswa yang menjadi partisipan penelitian (38\% orang dari 1007 partisipan yang ditanyakan) menyatakan bahwa, hal yang paling menghambat mereka untuk membaca adalah bacaan yang membosankan dan tidak menemukan bacaan yang menyenangkan. Selain itu, kebanyakan mereka (sebanyak 88\% dari 1007 partisipan) juga menyatakan bahwa mereka akan lebih banyak membaca jika menemukan bacaan yang mudah dibaca, tidak membuat pusing dan bingung.

Hal tersebut sesungguhnya sesuai dengan karakter generasi milenial. Mereka lebih suka membaca hal-hal yang mudah dipahami dan tidak tebal (Rukmana, 2018: 197). Hal tersebut dapat dilihat sebagai akibat dari teknologi informasi dan gawai yang menguasai mereka. "Simple" atau sederhana dan "mudah digunakan" adalah kosa kata yang menyertai kecanggihan teknologi informasi dan gawai. Kosa kata ini kemudian berpengaruh ke dalam berbagai aspek kehidupan generasi milenial, termasuk dunia literasi membaca.

Adapun 'membaca untuk kesenangan' adalah membaca yang tidak hanya dimaknai sebagai kegiatan reseptif mencerna pengetahuan semata. Membaca untuk kesenangan mengandaikan pengalaman membaca dengan kegiatan bermain karena terdapat efek relaksasi dan kenikmatan yang 
ditimbulkan. Alasan emosional-yang mengemuka dalam perasaan rileks dan bahagia ketika membaca, merupakan salah satu yang menumbuhkan minat membaca. Selain itu, menurut beberapa hasil penelitian, membaca untuk kesenangan dapat mempengaruhi prestasi akademik seseorang (Dewayani, 2017: 32). Terkait dengan membaca untuk kesenangan ini, diketahui sebanyak $22 \%$ partisipan mahasiswa membaca satu buku dalam sebulan, dan sebanyak $15 \%$ orang partisipan membaca dua buku dalam sebulan. Selebihnya mereka ada yang hanya membaca tidak tuntas, bahkan tidak membaca sama sekali karena tidak ada bacaan yang mereka senangi.

\section{Membaca genre fiksi lebih disukai mahasiswa}

Lalu apa yang sesungguhnya bacaan yang disenangi mahasiswa? Hal yang paling tampak dari jawaban-jawaban partisipan adalah mengenai kesukaan mereka terhadap teksteks bergenre fiksi dan buku-buku motivasi. Ketika ditanya tentang jenis teks yang paling disuka, separuh lebih partisipan (61\% dari 1007 partisipan) menjawab bahwa mereka lebih menyukai teks begenre fiksi daripada non fiksi. Fiksi di sini lebih dimaksudkan sebagai bacaan-bacaan yang berisi cerita tertentu. Lebih rinci lagi, dari genre fiksi tersebut, terbanyak menjawab bahwa tema yang paling digemari adalah fiksi romantis, lalu berturut komedi, religi, kepahlawanan dan horor meskipun kenyataannya dalam genre fiksi, berbagai tema bisa saja terdapat dalam satu karya, tetapi tetap memiliki tema dominan.

Kesenangan terhadap bacaan dengan genre fiksi juga merupakan salah satu karakter generasi milenial (Pahdepie, 2018: 201). Selain itu, menurut psikologi kognitif, cerita yang tersaji dalam genre fiksi memudahkan mekanisme kerja 
otak manusia. Manusia mendengarkan dan menceritakan cerita, bahkan sejak mereka mulai berbicara. Ketika seseorang masih menjadi anak kecil, ia menuturkan cerita yang biasanya mengabaikan kebenarannya, karena baginya yang terpenting adalah urutan cerita. Mekanisme kerja memori otak terstrukturkan dengan urutan dalam cerita. Artinya cerita yang dituturkan, dibacakan atau dibaca membantu orang untuk mengingat isi dalam cerita. Cerita juga, dalam budaya dan tradisi mana pun di dunia, adalah bentuk komunikasi manusia yang paling purba. Bercerita juga adalah metode pengajaran yang paling tua dalam sejarah manusia. Otak manusia sudah tertanam struktur cerita: awal, tengah, akhir. Mengurutkan materi pembelajaran dengan ketiga struktur tersebut yang menyerupai sebuah cerita, akan memudahkan siswa atau mahasiswa untuk memahami materi pelajaran. Berpikir dalam struktur cerita merupakan salah satu keterampilan berpikir dengan bahasa yang penting (Dewayani, 2017: 72-73).

Menurut hasil penelitian Pahdepie (2018: 204), anak-anak muda milenial, termasuk mahasiswa tertarik dengan genre fiksi bukan hanya pada aspek cerita atau tema cerita yang disampaikan. Mereka tertarik pada sesuatu yang melampaui cerita itu, yakni sesuatu yang memberikan makna bagi mereka. Jika sebuah cerita bisa mengubah atau menggugah sesuatu dalam diri mereka, mereka akan cenderung untuk mengikuti cerita tersebut. Mereka tidak hanya ingin membaca narasi cerita, tetapi juga ingin ikut larut bermain (interplay) dalam narasi. Tidak heran, ketika ditanya tentang judul buku fiksi yang mereka senangi, kebanyakan menjawab Negeri 5 Menara karya A Fuadi. Meskipun tidak jelas benar kategori fiksi di dalam novel tersebut, namun kadar narasi yang 
dibangun adalah cerita yang memberikan motivasi tampak jelas di dalam novel tersebut, tidak perduli kadar fiksi sejauh mana di dalam sebuah novel atau cerita.

Genre fiksi tersebut dapat disebut dengan fiksi bergenre realistik, yakni cerita yang latar kontemporer atau masa kini dan latar masa lalu atau sejarah. Fiksi realistik biasanya digunakan untuk mengajarkan nilai moral karena menggambarkan pergulatan seorang tokoh dalam menjalani masalah yang dihadapinya dalam kesehariannya. Kisah ini mewakili permasalahan atau pengalaman sehari-sehari pembaca sasaran. Kekuatan cerita fiksi realistik terletak pada kekuatan karakter tokoh cerita. Cerita fiksi bergenre realistik menggambarkan perilaku tokoh, keinginannya, caranya berpikir dan caranya menyelesaikan masalah yang mewakili pembaca sasaran, alur cerita mendukung karakter tokoh, alur awal, tengah dan akhir menggambarkan pemecahan masalah sang tokoh, cerita mendorong pembaca sasaran untuk berpikir, nilai-nilai moral dalam cerita disampaikan dengan tanpa menggurui (Dewayani, 2017: 73). Itulah kekuatan fiksi realistik yang banyak disenangi anak-anak muda, termasuk mahasiswa.

Dengan uraian tersebut sebetulnya menjadi jelas bahwa, kegairahan mahasiswa atau anak-anak muda terhadap genre fiksi adalah hal yang dapat dimengerti, baik dari perspektif karakter generasi milenial, maupun psikologi pembelajaran. Membaca untuk mempelajari sesuatu dan membaca untuk kesenangan sebetulnya bisa saling melengkapi, sebab membaca untuk kesenangan yang berbentuk genre fiksi dapat memberikan pelajaran tertentu yang juga berguna dalam kehidupan seseorang. Membaca fiksi yang menyenangkan dapat menjadi pemicu bagi kegairahan mahasiswa dalam 
membaca untuk mempelajari pengetahuan tertentu. Membaca fiksi juga dapat melatih ketahanan dan kesabaran dalam membaca suatu bacaan yang berisi informasi atau pengetahuan tertentu.

\section{Membaca literatur non fiksi}

Selain bacaan fiksi, partisipan juga membaca bacaan bergenre non fiksi. Bacaan non fiksi menjadi "bacaan wajib" sebab ia berada di dalam "arena resmi" pembelajaran atau perkuliahan. Selain buku-buku teks perkuliahan, sebanyak $26 \%$ mahasiswa partisipan menyenangi bacaan-bacaan non fiksi yang bertema sosial-kebudayaan, $25 \%$ orang lebih menyenangi literatur keagamaan, 23\% orang lebih suka membaca tema-tema sains dan teknologi, serta $18 \%$ orang membaca literatur bertemakan sejarah, selebihnya, yakni hanya sebanyak $8 \%$ orang yang membaca tema filsafat. Tampak bahwa urutan tiga teratas adalah literatur sosialbudaya, keagamaan, serta sains dan teknologi. Hal ini dapat dipahami karena memang ilmu-ilmu atau mata kuliah yang diajarkan adalah seputar tiga tema tersebut.

Hanya sedikit mahasiswa yang menjadi partisipan membaca literatur yang bertemakan filsafat. Padahal, mereka suka untuk menampilkan kata-kata mutiara atau bijak yang bersumber pada pandangan-pandangan filosofis tertentu. Banyak pengalaman para dosen yang menunjukkan bahwa ketika mahasiswa diajak membaca buku-buku pemikiran di bidang agama dan filsafat mereka susah atau tidak tertarik, tetapi ketika disodorkan kutipan-kutipan inspiratif, mereka akan segera tertarik dan kemudian menampilkan dalam beragam media sosial yang mereka miliki, mulai dari Facebook, Twitter dan Instagram (Rukmana, 2018: 197). 
Ketika mereka diperintahkan menulis sebuah ulasan buku dari sebuah pemikiran keagamaan atau filsafat tertentu, mereka merasa tidak mampu dan bingung harus menulis apa, namun ketika disampaikan kata-kata bijak yang bersumber dari buku pemikiran tersebut mereka rajin mencatat, demikian ujar seorang dosen yang diwawancarai di UIN Mataram (wawancara dengan salah seorang dosen Studi AgamaAgama Fakultas Tarbiyah dan Keguruan, 22 Mei 2018).

Dengan begitu, bisa dipahami bahwa di antara bacaanbacaan non fiksi di luar bacaan yang digunakan dalam ruang atau arena perkuliahan yang disenangi di kalangan mahasiswa adalah bacaan-bacaan yang memberikan motivasi. Seorang mahasiswa menceritakan mengapa ia menyenangi bacaanbacaan yang memberikan motivasi. Ia menceritakan bahwa:

Ayah saya meninggal ketika umur satu tahun. Saya dibesarkan oleh kakek nenek di kampung pelosok desa. Sangat jauh dari keramaian dan kericuhan kota. Ibu, harus bekerja mencari nafkah untuk mnghidupi kami, karena anak-anak kakek dan nenek saya merantau jauh mengikuti suami mereka. Hanya ada saya, paman (adik bungsu ibu), kakek dan nenek yang tersisa di rumah reot kakek. Lokasi kerja ibu beda kabupaten, dan pulang hari Sabtu sore, pergi pagi Ahad sore, selalu menyisakan isak yang berjam-jam hingga kakek pun menangis melihat saya memanggil-manggil ibu. Dari keterbiasaan itulah, menyendiri, diam, dan sepi adalah kehidupanku. Itulah mengapa saya senang dengan membaca buku-buku yang memotivasi. Mulai tsanawiyah, saya banyak membaca buku-buku model quantum teaching, learning dan kiat-kiat sukses (wawancara dengan Nurma, 26 Juni 2018).

Membaca buku-buku motivasi dapat menjadi "obat" bagi "kegalauan" anak muda. Kosa kata "galau" menjadi trending topik di tahun 2009 dengan tagar \#galau di media sosial twitter, sehingga membuat kehebohan global. Sampai saat ini kosa kata galau masih sering terucap di kalangan anak muda, termasuk mahasiswa. Menurut beberapa riset psikologis, 
meskipun generasi milenial merupakan generasi yang kreatif (Ali dan Purwandi, 2017: 90), namun mereka berada dalam kegalauan. Kegalauan tersebut diakibatkan oleh masalahmasalah personal yang muncul, masalah sosial dan ekonomi. Masalah personal seperti masalah keluarga yang dihadapi, masalah sosial dan ekonomi seperti masalah minder karena tidak memiliki keahlian, serta tidak memiliki masa depan pekerjaan yang jelas. Akhirnya, buku-buku motivasi menjadi semacam "pelarian" bagi kegalauan anak muda.

\section{Perilaku literasi menulis}

Adapun perilaku literasi menulis, kebanyakan (60\% dari 1007 mahasiswa yang diwawancara) justru mengaku senang menulis. Partisipan (63\% dari 1007 mahasiswa) lebih senang menulis genre fiksi dari pada non fiksi. Hal ini selaras dengan kesenangan membaca genre fiksi sebagaimana telah dipaparkan. Maksud genre fiksi ini pun luas, termasuk menuliskan puisi, terutama puisi-puisi romantis. Namun, partisipan tidak banyak mengartikulasikan tulisan-tulisan mereka di media massa. Hanya $28 \%$ partisipan yang menjawab pernah menulis di media massa, baik online maupun cetak. Hal ini juga menunjukkan bahwa partisipan tidak banyak menunjukkan perilaku menulis, meskipun sadar bahwa menulis itu dapat mengekspresikan ide. Justru dengan sadar bahwa menulis dapat mengekspresikan ide, partisipan kesulitan dalam menadapatkan ide dan menuangkannya dalam sebuah tulisan.

Meskipun demikian, partisipan juga tetap menulis, terutama menulis untuk tujuan perkuliahan. Sebab, sebagaimana yang sudah disebutkan, dalam tugas-tugas sehari-hari mereka dituntut untuk menulis, baik menulis 
makalah, review buku atau artikel, maupun peta konsep. Banyak partisipan (63\% partisipan) mengaku bahwa mereka akan menulis dengan lebih baik jika dosen memberikan tugas memberikan makalah. Artinya motivasi menulis mereka lebih merupakan motivasi ekstrinsik, yakni menulis sekadar memenuhi tugas perkuliahan.

Menulis lebih baik untuk memenuhi tugas menurut Hugo Hartig sebagaimana dikutip oleh Tarigan (2013: 25) sebagai tujuan penugasan (assignment purpose). Tujuan penugasan ini sebenarnya tidak memiliki tujuan yang substantif. Penulis menulis sesuatu karena ditugaskan, bukan atas kemauan sendiri. Berbeda dengan tujuan-tujuan penulisan yang lain, seperti tujuan altruistik, tujuan persuasif, tujuan penerangan (informasional), tujuan pernyataan diri, tujuan kreatif dan tujuan pemecahan masalah. Penulisan makalah seharusnya dapat digunakan sebagai ajang untuk memberikan informasi, pernyataan diri maupun pemecahan masalah. Namun, yang banyak dilakukan oleh mahasiswa baru sebatas untuk memenuhi tugas. Ada pengalaman yang diceritakan oleh salah seorang dosen ketika memberikan tugas dan menanyakan sesuatu yang tertulis di dalam makalah. Ketika ditanya suatu hal, mahasiswa kebingungan untuk menjawab pertanyaan tersebut, padahal menurut sang dosen, tulisan atau jawaban dari pertanyaan yang dilontarkan sebetulnya telah ada dalam bagian dari tulisan yang dibuat mahasiswa tersebut (wawancara dengan Ketua Jurusan PAI UIN Mataram, 17 Mei 2018).

Kegiatan penulisan yang bertujuan hanya memenuhi tugas sesungguhnya dapat menjadi "pintu masuk" pembelajaran literasi menulis yang esensial. Tujuan pembelajaran literasi menulis yang esensial yaitu: (1) Pembelajaran literasi 
menulis bertujuan agar kegiatan menulis digunakan sebagai sarana memahami teks atau konsep keilmuan tertentu; (2) Pembelajaran literasi menulis bertujuan agar keterampilan menulis digunakan untuk mengkritisi informasi ataupun konsep-konsep tertentu yang sedang dipelajari; Pembelajaran literasi menulis bertujuan agar mahasiswa mampu menghasilkan berbagai jenis tulisan sesuai dengan konteks keilmuan, jenis tulisan, tujuan penulisan dan sasaran pembacanya (Abidin, Mulyati dan Yunansah, 2017: 211-212).

Hal tersebut tampak dalam beberapa karya mahasiswa UIN Maulana Malik Ibrahim misalnya, seperti karya tulis Eman Suherman dan Agus Suadi Hasan. Karyanya berjudul "Fruitanol Energy Product: Biokonversi Limbang Buah sebagai Tawaran Produk Sumber Energi Terbarukan dalam Mewujudkan Kedaulatan Energi Ramah Lingkungan (Studi Bioteknologi QS. An-Nahl: 67 dan QS. Yasin: 80). Menurut kedua penulis ini, ini adalah salah satu bentuk karya tulis yang diajukan dalam sebuah lomba yang awalnya berdasarkan pada tugas kuliah. Berawal dari tugas tersebut, kedua mahasiswa ini melanjutkan minat penelitian dan penulisan dalam lomba. Mahsiswa ini juga mengatakan bahwa, tulisan ini adalah sebagai bentuk implementasi penelitian yang berbasis integrasi keilmuan, antara ilmu-ilmu keislaman dengan ilmuilmu umum.

Namun tujuan-tujuan tersebut tidak akan berjalan jika tidak memperhatikan metode atau strategi pembelajaran literasi yang sesuai dengan ciri generasi milenial. Sebagaimana telah dikemukakan bahwa salah satu ciri generasi milenial adalah connected, terhubung dengan internet dan media sosial. Hal tersebut misalnya dengan memberikan tugas kepada mahasiswa dengan cara yang lebih 
kreatif dan menghubungkan mereka dengan dunia internet atau media sosial yang disenangi mereka, yakni menampilkan tulisan-tulisan mereka ke dalam sebuah blog tertentu atau menuliskan suatu pokok pikiran dari suatu permasalahan atau topik dalam perkuliahan di media sosial. Dengan cara seperti ini sebetulnya dapat mengurangi dampak negatif dan keluhan sebagaian pendidik, termasuk dosen, yang menunjukkan bahwa gawai telah mengalihkan minat generasi digital dari kegiatan menulis.

Menurut Dewayani (2017: 153) kehadiran media dapat memediasi ekspresi diri secara lebih kreatif dan terbuka. Melalui media sosial, anak-anak muda, termasuk mahasiswa di generasi milenial sering menuliskan suatu komentar, berpartisipasi dalam diskusi, dan mencurahkan pikiran dan perasaan mereka pada media sosial. Sebelum generasi milenial, mungkin buku harian yang memediasi. Melalui buku harian, pikiran dan perasaan ditulis diam-diam, disimpan dan dikunci. Namun, saat ini hal tersebut sudah jarang dilakukan generasi milenial. Mereka mencurahkan pikiran dan perasaannya agar dibaca oleh lingkaran sosialnya. Mereka menulis untuk berbagi. Media sosial dapat mengakomodasi menulis sebagai kegiatan sosial, menjadi kegiatan produktif yang melahirkan diskusi dan karya. Kegiatan menulis di media sosial saat ini juga tidak lagi harus dibatasi menulis narasi tulisan, namun juga foto dan video. Beberapa media sosial yang bisa digunakan sebagai ajang menulis untuk mahasiswa adalah Blog, Facebook, Twitter, Instagram dan forum-forum diskusi atau studi yang ada pada grup Facebook misalnya. Dengan memberikan mahasiswa untuk menulis di media sosial, berarti mendekatkan materi pembelajaran dengan kehidupan mahasiswa. Jika tugas-tugas menulis mahasiswa 
yang diberikan dengan strategi seperti ini, mahasiswa akan lebih cenderung menyenangi kegiatan literasi menulis, karena unsur-unsur yang melekat dalam media sosial, seperti keterhubungan dan aktualisasi diri, adalah juga ciri-ciri yang ada dalam diri mahasiswa generasi milenial. Selain itu, dengan penugasan karya tulis melalui media sosial juga akan mengurangi kebiasaan buruk plagiat yang marak terjadi.

\section{Perilaku Plagiat atau "Copy-Paste": Perilaku Tidak Literat}

Terkait dengan perilaku literasi membaca dan menulis, penting juga dibahas mengenai "budaya" plagiat yang dilakukan mahasiswa, atau yang banyak mahasiswa sebut dengan copy-paste. Copy-paste adalah salah satu fungsi dalam komputer yang memungkinkan seseorang bekerja menyalin dan memindahkan satu tulisan ke tempat tertentu yang berbeda. Secara teknologi hal tersebut tentu memudahkan jika akan menempatkan satu tulisan ke tempat yang lainnya. Bagi editor sebuah tulisan, program seperti ini pun memudahkan dalam mengedit atau merapihkan sebuah tulisan. Namun, program komputer ini sering digunakan untuk tujuan mempercepat penyelesaian sebuah tulisan, yakni memindahkan satu tulisan tertentu ke dalam tulisan lainnya yang kemudian dianggap sebagai karya yang berbeda, padahal isinya adalah salinan dari sumber yang sama. Parahnya lagi, terkadang perilaku ini kemudian tidak menyebutkan sumbernya, sehingga yang terjadi bukanlah mengacu (refer) tetapi melakukan plagiasi.

Perilaku seperti ini yang banyak dilakukan oleh mahasiswa. Anehnya hal itu disadari oleh mereka. Dalam beberapa forum diskusi terfokus di semua kampus yang diteliti, partisipan mengakui bahwa "budaya copy-paste" sering 
mereka lakukan untuk mempercepat penyelesaian tugas, meskipun ada beberapa partisipan yang tetap mengandalkan karya sendiri dengan merujuk sumber-sumber yang benarbenar dibaca. Hal yang sama juga diakui beberapa dosen. Seorang dosen menceritakan bahwa dia pernah menunda nilai ujian akhir skripsinya karena diketahui kalau skripsi tersebut hasil plagiat dari karya skripsi lainnya (wawancara dengan dosen Jurusan Pendidikan IPS Fakultas Tarbiyah dan Keguruan UIN Mataram, 17 Mei 2018).

Menurut penuturan seorang dosen, budaya membaca di kalangan mahasiswa sangat rendah, padahal dosen sudah berupaya memberikan bahan bacaan sebagai bahan perkuliahan. Selain itu, penugasan makalah justru membuat mahasiswa melakukan plagiat, sebab kurangnya budaya membaca. Mereka banyak melakukan plagiat berdasarkan sumber-sumber internet. Karena itu, kini dosen banyak melakukan penugasan dengan menulis esai dalam satu waktu (tidak dikerjakan di rumah) atau membuat peta konsep yang harus dijelaskan saat presentasi. Dengan cara seperti ini, mahasiswa dilatih untuk membaca sumber-sumber referensi dan memahami bacaan tersebut karena harus mempresentasikan dalam forum diskusi di kelas (wawancara dengan dosen Akhlak-Tasawuf, Jurusan IPS Fakultas Tarbiyah dan Keguruan UIN Mataram, 17 Mei 2018). Hal tersebut juga dilakukan oleh dosen sosiologi pendidikan Islam. Dosen tersebut mengatakan lebih banyak menugaskan untuk membuat peta konsep, lalu hasil pemahaman peta konsep itu disampaikan dalam forum diskusi dengan metode jig saw, yakni masing-masing anggota kelompok mendapatkan giliran untuk menyampaikan materi yang didiskusikan dalam kelompok lainnya, begitu juga sebaliknya. Ini dilakukan 
sebagai bentuk upaya menghindari perilaku plagiat yang banyak dilakukan mahasiswa (wawancara dengan dosen Sosiologi Pendidikan Islam, 17 Mei 2018).

Plagiat menurut Kamus Besar Bahasa Indonesia V, adalah pengambilan karangan (pendapat) orang lain dan menjadikannya seolah-olah karangan (pendapat) sendiri, misalnya menerbitkan karya tulis orang lain atas nama dirinya sendiri (jiplakan). Sedangkan "plagiarisme" adalah penjiplakan yang melanggar hak cipta. Demikian pengertian secara bahasa yang sama juga diberikan dalam bahasa Inggris sebagaimana di dalam kamus Oxford dan Cambridge.

Menurut Susan D Blum (2009: 12), meskipun arti plagiat dan plagiarisme terlihat jelas dan tunggal, tetapi sebetulnya memiliki arti yang berlapis. Plagiarisme dapat dilihat dalam konsep tiga entitas, sebuah konsep triangle (segi tiga). Pada satu titik segitiga, plagiarisme adalah sejenis kecurangan yang melibatkan karya tulis. Seorang siswa atau mahasiswa dengan sadar, sengaja, dan dengan jelas terlibat dalam perilaku terlarang seperti membeli makalah, sebuah tindakan yang memasuki wilayah kriminalitas sadar, atau penipuan yang merupakan kejahatan akademis. Titik kedua, sudut ketidaksengajaan, yakni plagiarisme adalah hasil dari kegagalan untuk menguasai konvensi. Praktik mengutip yang tepat adalah keterampilan yang sulit untuk diperoleh. Hal tersebut dapat dipelajari hanya melalui pengajaran yang hati-hati. Siswa dan mahasiswa biasanya membuat kesalahan tentang cara mengutip tanpa bermaksud melanggar peraturan, apalagi hukum. Sudut ketiga adalah "profesional" yang mencuri karya penulis lain tanpa izin dan untuk kepentingan mereka sendiri. Di sudut profesional ini, pelanggaran hak cipta dan masalah hukum lainnya ikut terjadi. 
Berdasarkan pengakuan partisipan mahasiswa pada forum-forum diskusi terfokus, sesungguhnya mereka sadar bahwa mereka salah ketika melakukan copy-paste tersebut. Mereka terburu-buru mengerjakan tugas agar cepat selesai sementara tugas lainnya sudah menanti. Jika melihat tiga sisi plagiarisme sebagaimana yang diajukan oleh Blum, hal yang kurang diberikan adalah bagaimana memberikan pengetahuan yang baik tentang bagaimana mengutip dalam sebuah karya sehingga tidak terjatuh pada plagiarisme. Pemberian pengetahuan dan keterampilan tentang cara pengutipan yang baik adalah bagian dari upaya mengarahkan kualitas literasi yang baik. Sebab, mengutip yang baik tidak akan terwujud dengan baik kalau tidak menjadi pembaca yang baik. Selain itu, yang penting ditekankan adalah pendidik, dalam hal ini dosen perlu mengarahkan motivasi dalam belajar sehingga tidak terjadi plagiarisme.

Blum (2009: 125) yang meneliti tentang perilaku plagiat mahasiswa di sebuah universitas di Amerika Serikat secara antropologis mengungkapkan bahwa perilaku plagiat dapat dilihat dari motivasi mahasiswa dalam belajar. Sebagaimana diketahui, para ahli pendidikan mengidentifikasi dua motivasi belajar, yakni motivasi intrinsik dan motivasi ekstrinsik. Motivasi intrinsik untuk belajar adalah cinta pengetahuan untuk dirinya sendiri, atau kebutuhan untuk pengetahuan dalam aplikasi. Sedangkan motivasi ekstrinsik belajar adalah mendapatkan nilai bagus, pujian guru atau orang tua, ijazah, pekerjaan. Mahasiswa yang memiliki motivasi instrinsik dalam belajar cenderung untuk tidak terburuburu atau melakukan plagiat dan menipu, karena mereka menikmati pengalaman belajar itu sendiri. Namun, tidak dapat dipungkiri bahwa, administrasi dan evaluasi pendidikan 
selalu mempertimbangkan nilai mahasiswa sebagai salah satu fokus utama perhatian mereka, dan karenanya mahasiswa mau mengambil langkah apa pun yang ada untuk memastikan nilai yang baik, termasuk melakukan plagiasi. Perlu sebuah upaya jalan tengah, dan beberapa dosen di kampus yang menjadi lokasi penelitian ini telah mengajukan upaya-upaya untuk mengurangi dan mencegah perilaku plagiat ini.

Harus dipahami bahwa salah satu problem generasi milenial, sebagaimana telah dijelaskan pada bab dua, adalah takut gagal dan demotivasi secara akademik dan tantangan karir (Faisal, 2017: 116), sehingga mereka berupaya untuk sukses dalam pendidikan dan karir. Dengan begitu, mereka akan selalu berupaya memenuhi tugas-tugas perkuliahan agar mendapatkan nilai yang baik, lulus lalu mendapatkan pekerjaan yang layak. Setidaknya dapat lulus secara memuaskan dan lepas dari tanggungjawab akademik, dan bekerja sesuai minat mereka. Ini menyiratkan bahwa mahasiswa membutuhkan motivasi untuk menghadapi berbagai tugas kehidupan, termasuk tugas-tugas perkuliahan yang dikerjakan secara bertanggung jawab. Sebagaimana telah dibahas juga, mahasiswa generasi milenial selalu terbuka dengan motivasi, termasuk motivasi untuk tidak melakukan plagiarisme. Motivasi untuk tidak melakukan plagiarisme berarti juga motivasi untuk menjadi lebih literat dalam perilaku.

\section{Komunitas Literasi Mahasiswa: Membaca Artefak Motivasi Intrinsik Literasi}

Ada sebagian mahasiswa yang aktif mempraktikan literasi. Hal ini penting diungkapkan di tengah buruknya perilaku literasi mahasiswa sebagaimana yang telah digambarkan, 
seperti perilaku plagiasi. Selain itu, komunitas literasi mahasiswa penting dikemukakan di sini untuk menempatkan posisi mereka sebagai penggerak literasi kepada teman-teman sebayanya sesama mahasiswa. Penting diingat kembali, sebagaimana yang sudah dijelaskan pada bab dua, bahwa budaya peer group adalah salah satu kunci untuk memahami mahasiswa generasi milenial. Anak muda secara psikologis memiliki kebutuhan untuk mengkonfirmasi apakah hal yang mereka lakukan dan apa yang mereka rasakan sudah benar atau sudah berada di jalur yang sesuai secara sosial menurut kelompoknya. Peer group (kelompok sebaya), komunitas dan lingkungan sosial secara luas berfungsi sebagai tempat mendapatkan konfirmasi tersebut (Faisal, 2017: 147).

Kelompok mahasiswa ini dapat dikelompokkan setidaknya ke dalam tiga kategori atau kelompok. Kelompok ini telah mempraktikan literasi membaca dan menulis sekaligus. Karena itu, dapat dikatakan kelompok ini sebagai kelompok mahasiswa penulis. Pertama, mahasiswa yang aktif di lembaga pers mahasiswa. Kedua, mahasiswa yang aktif di komunitas diskusi dan kepenulisan, baik yang ada di dalam kampus maupun di luar kampus. Ketiga, mahasiswa yang secara mandiri menyalurkan minatnya untuk membaca dan menulis. Mungkin ada kategori-kategori lain yang bisa diajukan, tetapi sepanjang data yang ditemukan dalam penelitian ini, ketiga kategori itulah yang dapat diajukan. Tentu saja, kelompok mahasiswa yang aktif menulis (sebagai wujud praktik literasi) bukan karena hanya menunaikan tugas sebagai mahasiswa di kelas, tetapi menulis karena minat dan kebutuhan berbagi ide serta aktualisasi diri. Mahasiswa yang aktif menulis di sini dapat dikatakan sebagai "mahasiswa yang menulis untuk memenuhi minat menulis" bukan 
sebagai "mahasiswa yang menulis untuk memenuhi tugas perkuliahan". Mahasiswa yang pertama terkategori menulis karena motivasi instrinsik, sedangkan tipe mahasiswa yang kedua adalah mahasiswa yang menulis karena motivasi ekstrinsik.

\section{Lembaga Pers Mahasiswa}

Lembaga Pers Mahasiswa (LPM) menjadi salah satu Unit Kegiatan Mahasiswa (UKM) di kampus. Lembaga pers mahasiswa adalah lembaga penerbitan, dalam berbagai bentuk seperti majalah, tabloid, newsletter, bahkan media online yang seluruh prosesnya dikelola oleh mahasiswa, mulai dari pencarian informasi, penulisan, tata letak dan distribusi. Berbagai kampus yang diteliti memiliki UKM Pers Mahasiswa ini. Seorang alumnus atau mantan aktivis Pers Mahasiswa (T) di UIN Walisongo menuturkan sebagai berikut.

Pers mahasiswa sebenarnya imitasi ideal pers umum, karena kampus pun sebenarnya imitasi dari masyarakatnya. Di kampus pers mahasiswa mendapatkan habitatnya yang tepat untuk berperan dan dimanfaatkan sepenuhnya untuk pengembangan sosial-intelektual mahasiswa dan kampus itu sendiri. Kampus sebagai locus intelektual sangat sesuai dengan fungsi pers informatif, edukatif, dan kontrol sosial (serta hiburan tentu saja). Mahasiswa aktivis pers mahasiswa dapat mengembangkan kemampuan intelektualnya melalui saluran itu, mahasiswa dan sivitas secara umum memperoleh manfaat atas sumbangan intelektual tersebut melalui produk-produk media yang dihasilkan. Ranah intelektual tentu tidak hanya dampak pengetahuan, tetapi juga dinamika sosial politik, di mana fungsi kontrol sosial ada di wilayah ini. Politik kampus dalam hal kebijakan ataupun kontestasi kekuasaan dapat dikontrol melalui jalur informasi, dan itu butuh kemampuan penalaran daya analitik yang terasah melalui kemampuan menulis yang terstruktur. Maka umumnya anak Persma (Pers Mahasiswa-Peneliti) cenderung lebih kritis. Kemampuan 
menulis ini sekaligus juga menjadi kunci pengembangan intelektual, promosi ide, penyebaran gagasan (cetak tebal oleh peneliti) (wawancara dengan T, mantan aktivis Pers Mahasiswa di UIN Walisongo Semarang, 29 Juni 2018).

Kalimat terakhir dalam kutipan di atas dapat lebih memperjelas tentang fungsi pers mahasiswa di kampus. Intinya, lembaga pers mahasiswa dapat menjadi wadah mahasiswa mengaktualisasikan ide dan imajinasi dalam berbagai media yang diterbitkan, baik cetak maupun online. Data yang didapatkan dari enam kampus yang diteliti menunjukkan betapa Lembaga Pers Mahasiswa betul-betul menjadi ajang kreativitas menulis bagi para anggotanya, bahkan mahasiswa-mahasiswa yang tidak ikut aktif dalam organisasi LPM terkadang turut menyumbangkan tulisan ke media-media yang diterbitkan LPM

Kampus UIN Sunan Kalijaga memiliki LPM yang dikenal dengan "Arena." Majalah yang diterbitkan pun dan menjadi terkenal bernama Majalah Arena. LPM Arena adalah lembaga pers mahasiswa di tingkat universitas. LPM ini lahir pada 10 Januari 1975. Misi LPM Arena adalah menjadi media komunikasi antar mahasiswa, penumbuh kreasi dan pembawa aspirasi mahasiswa, juga sebagai media kontrol. Selain itu secara khusus LPM Arena juga berusaha memberikan informasi yang bernada optimistik, persuasif dan berwawasan pembebasan terhadap mahasiswa dan masyarakat Indonesia. Adapun visi LPM Arena adalah membangun integritas kampus, dengan mendorong kerja praktis LPM Arena agar bisa menggabungkan dua hal pokok yaitu penggalian dan penyebaran informasi alternatif-kritis, dengan pendampingan (advokasi) dan pembelaan pada kasuskasus yang secara tidak adil dan menindas dialami rakyat di 
level akar rumput (https://lpmarena.com/tentang-kami/).

Untuk merealisasikan misi di atas, LPM Arena menerbitkan beberapa media, diantaranya adalah: Majalah ARENA "Kancah Pemkiran Alternatif", Newsletter SLILIT "Jelas dan Mengganjal", portal media online lpmarena.com, serta buku-buku tentang jurnalistik dan gerakan mahasiswa. Selain itu, untuk mencapai sumber daya manusia yang dinamis, kritis dan profesional yang diharapkan dan menjadi cita-cita LPM Arena, LPM Arena juga melaksanakan pendidikan, pelatihan, pengembangan dan advokasi dengan orientasi kepada pemberdayaan anggota, mahasiswa, dan masyarakat secara umum. Kegiatan-kegiatan yang dilakukan antara lain adalah: pelatihan, workshop dan penelitian, Networking (Menjalin Kerjasama dengan Organisasi Lain), serta diskusi rutin dan bedah buku (https://pmarena.com/tentang-kami/).

Majalah Arena sendiri memiliki beberapa rubrik, yakni kancah, kupas dan sastra serta editorial. Selain rubrik editorial, Majalah Arena menerima sumbangan artikel dari para pembaca dari semua kalangan. Rubrik kancah berisi tulisantulisan informatif baik di lingkungan kampus, lokal, nasional maupun internasional. Sedangkan rubrik kupas berisi ulasanulasan tentang buku, film atau karya-karya kesenian lainnya yang sedang banyak diperbincangkan orang. Adapun rubrik sastra berisi karya-karya sastra dalam berbagai bentuknya, seperti cerita pendek (cerpen) dan puisi. Kebanyakan para penulis yang menyumbangkan tulisannya di Majalah Arena adalah mahasiswa, meskipun tidak aktif di LPM Arena.

Sekarang ini, masing-masing rubrik tersebut sudah tersedia di dalam lpmarena.com. Ini memberikan kemudahan tersendiri bagi pembaca untuk mengakses informasi dari Majalah Arena, selain juga untuk mengurangi beban biaya 
cetak. Selain memiliki portal berita online, LPM Arena juga memiliki media sosial, seperti instagram, facebook dan twitter. Keberadaan media sosial LPM Arena ini juga semakin mendekatkan dengan -gaya digital" pembaca media-media yang diterbitkan oleh LPM Arena.

Gambar 8. Tampilan Website LPM Arena

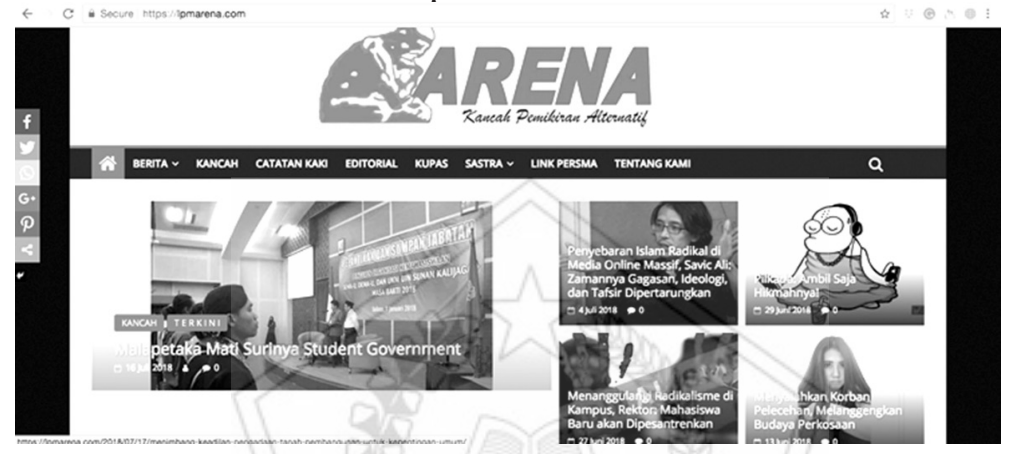

Sumber: Foto koleksi peneliti (Agus Iswanto)

Kampus UIN Walisongo Semarang memiliki Surat Kabar Mahasiswa (SKM) Amanat yang merupakan lembaga pers mahasiswa tingkat universitas. SKM Amanat sendiri berdiri pada tahun 1984, kemudian sejak tahun 2012 memiliki portal berita online dengan alamat www.skmamanat.com. SKM Amanat menjadikan isu kampus, kebijakan birokrat, aspirasi mahasiswa, informasi terkini UIN Walisongo, dan sekitarnya menjadi bahan pembahasan dapur redaksi setiap hari (https:// skmamanat.com/tentang-kami/\#).

Redaksi SKM Amanat berusaha menyajikan info terkini menjadi karya yang pantas disajikan untuk pembaca. Informasi yang termuat di dalam SKM Amanat melewati proses jurnalistik yang independen, terverifikasi, dan terkonfirmasi. SKM Amanat juga didesain sebagai saluran yang sesuai dengan kebutuhan mahasiswa UIN Walisongo, dengan menyajikan sejumlah rubrik, yakni Warta (baik 
warta kampus, lokal, nasional maupun internasional), Artikel, Milenial, Sastra Budaya, Sosok, dan Inforgrafik. SKM Amanat juga menyediakan arsip digital dalam bentuk e-paper sehingga mempermudah pembaca mengaksesnya (https://skmamanat.com/tentang-kami/\#)._Tampaknya, portal berita online SKM Amanat menyediakan lebih banyak rubrik jika dibandingkan dengan Arena. SKM Amanat juga memiliki berbagai media sosial yang semakin mempermudah jangkauan informasi yang disediakan.

Gambar 9. Tampilan Website SKM Amanat

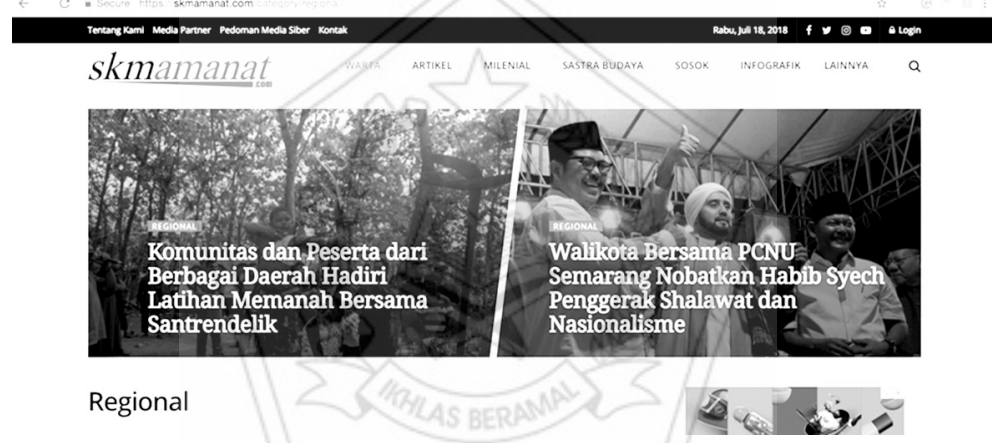

Sumber: Foto koleksi peneliti (Agus Iswanto)

Tidak hanya di tingkat universitas, di tingkat fakultas pun geliat aktivitas pers mahasiswa juga tampak semarak. Seperti di Fakultas Ushuluddin dan Humaniora serta Fakultas Syariah dan Hukum. Kedua fakultas ini memiliki Lembaga Pers Mahasiswa yang produktif menerbitkan produk literasi melalui media majalah, baik cetak maupun online. Lembaga Pers Mahasiswa di Fakultas Ushuluddin dan Humaniora memiliki majalah yang bernama IDEA. Majalah ini pun memiliki portal online dengan alamat http://www.ideapers. com/. Begitu pula Fakultas Syariah dan Hukum memliki majalah dengan nama Justisia yang juga memiliki portal online dengan alamat http://justisia.com/. 
Gambar 10. Tampilan Portal Majalah IDEAPERS Fakultas Ushuluddin dan Humaniora UIN Walisongo Semarang

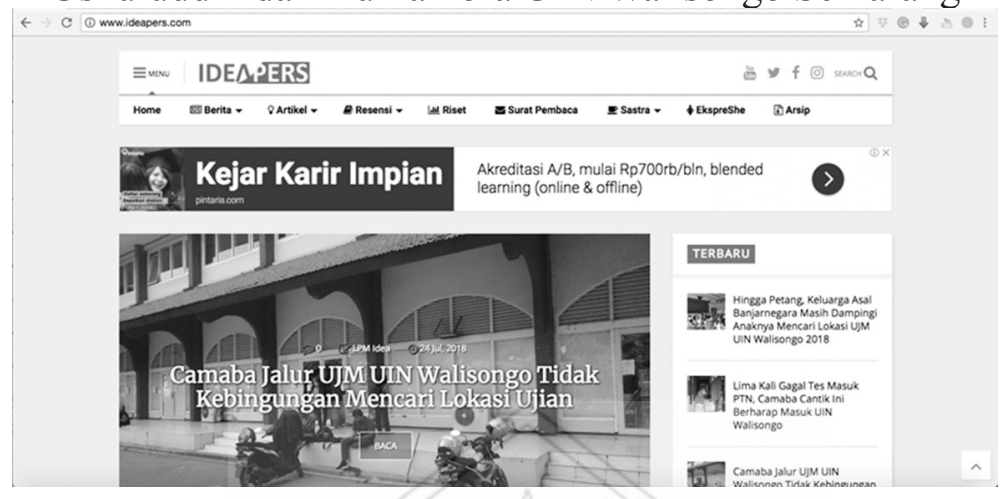

Sumber: Koleksi Peneliti (Agus Iswanto)

Tidak kalah dengan dua UIN di atas, UIN Sunan Ampel Surabaya juga memiliki Lembaga Pers Mahasiswa. Nama LPM di tingkat universitas pada UIN Sunan Ampel adalah -Solidaritas," yang juga menjadi nama medianya. LPM ini berdiri sejak tahun 2001, meskipun proses penerbitannya sudah mulai sejak tahun 1991. LPM Solidaritas lahir untuk mengakomodasi, memberi ruang dan wahana yang bertujuan untuk menyalurkan aspirasi dan kreasi mahasiswa dengan relevansi terhadap interdisipliner keilmuan yang ada. Visi dari LPM Solidaritas adalah sebagai garda depan perubahan. Adapun misinya antara lain: mendorong terbentuknya masyarakat kritis dan transformtif, melakukan pembelaan pada kaum tertindas, melakukan fungsi kontrol bagi terbentuknya sistem yang demokratis. Untuk mewujudkan visi-misi tersebut, LPM Solidaritas bekerja di bidang penerbitan Tabloid Solidaritas, penerbitan Koran Beranda, penerbitan Buletin Coret, pelatihan Jurnalistik dan kajian ilmiah (http://www.solidaritas-uinsa.org/lpm-solidaritasuinsa/). 
Seperti di dua kampus sebelumnya, LPM Solidaritas pun memiliki media online. Media online tersebut bernama "Media Solidaritas" dengan moto "Suara hati mahasiswa." Media ini juga memiliki berbagai macam rubrik, yakni berita, foto, features, opini, resensi, sastra, dan kabar solidaritas. Agak berbeda dengan media online Arena dan Amanat, Media Solidaritas memiliki rubrik foto. Jika dilihat dari aspek literasi, media ini sudah mengakomodir aspek literasi visual. Namun, dari sisi kontributor tulisan, sama seperti media kampus sebelumnya, banyak dari kalangan kalangan mahasiswa setempat. Media Solidaritas juga memiliki media sosial.

Gambar 11. Tampilan Website Media Solidaritas UIN Sunan Ampel Surabaya

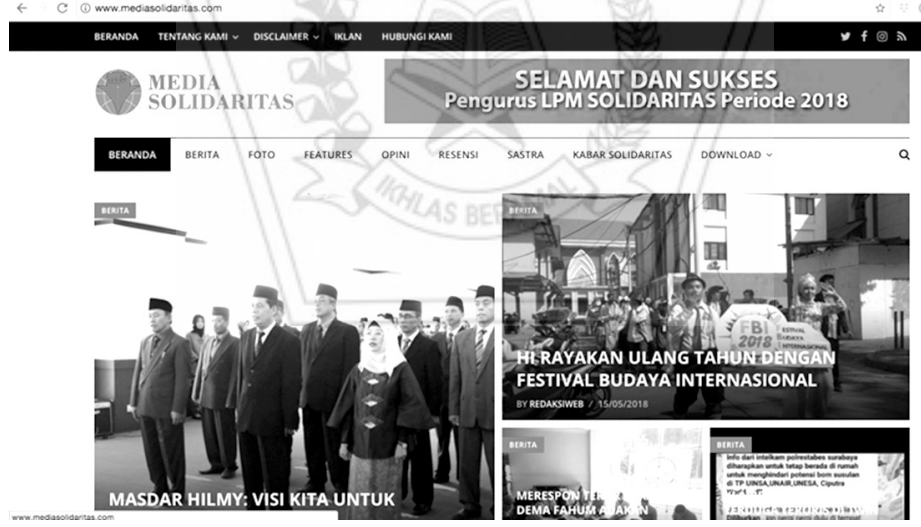

Sumber: Foto koleksi peneliti (Agus Iswanto)

UIN Maulana Malik Ibrahim Malang memiliki Lembaga Pers Mahasiswa, yang bernama Unit Aktivitas Pers Mahasiswa (UAPM) INOVASI. Lembaga ini berdiri pada 1986 dengan program inti menerbitkan buletin mahasiswa INOVASI yang mulai aktif sejak tahun 1991. Dengan visi memihak kesadaran nurani" UAPM INOVASI berkomitmen 
memaksimalkan potensi mahasiswa melalui kegiatan jurnalistik. Beberapa kegiatan yang dilakukan oleh unit ini selain penerbitan produk jurnalistik adalah pelatihan keterampilan di bidang desain grafis, fotografi, karikatur, dan penguatan wacana kritis (http://uapminovasi.com/samplepage-2/).

Beberapa produk jurnalistik karya unit pers mahasiswa INOVASI adalah Majalah INOVASI, Buletin Patriotik, Koran Tempel $Q$-Post, dan yang tak kalah pentingnya adalah media online dengan web www.uapinovasi.com serta media sosialnya. Majalah INOVASI menyajikan informasi peristiwa dalam lingkup kampus sampai lingkup nasional. Pemberitaan yang tersaji di dalam Majalah INOVASI bersifat Depth News (berita me ndalam) yang kritis-analitis. Adapun Buletin Patriotik terbit untuk menjamin kebutuhan civitas akademika akan sajian analitis-kritis terkait arah pembangunan kampus. Pemberitaan Buletin Patriotik bersifat Straight News (berita langsung) maupun Depth News. Sedangkan, Koran Tempel $Q$-Post merupakan media menulis yang bersifat rutin. Dengan pemberitaan yang bersifat Straight News, Koran Tempel Q-Post memiliki fokus pemberitaan peristiwa yang harus segera diberitakan (http://uapminovasi.com/sample-page-2/).

Untuk media online INOVASI, beberapa rubrik tersedia, seperti berita, artikel (opini, esai dan pojok), sastra dan resensi. Untuk rubrik berita, tersedia berbagai berita dalam berbagai produk jurnalistik UAPM INOVASI lainnya, seperti Buletin Patriotik dan Koran Tempel Q-Post. Berbagai rubrik di media ini juga tidak terbatas pada kalangan dalam aktivis pers INOVASI, tetapi juga menerima kontribusi tulisan dalam berbagai rubrik dari luar aktivis. Kebanyakan para penulis adalah mahasiswa UIN Maulana Malik Ibrahim. 
Selanjutnya adalah UIN Mataram, Unit Kegiatan Mahasiswa (UKM) yang membidangi pers mahasiswa bernama LPM Ro'yuna (yang dalam bahasa Arab berarti pikiran kami"). LPM Ro'yuna berdiri pada 17 September 1998. Sebagaimana disebutkan dalam Anggaran Dasar dan Anggaran Rumah Tangga LPM Ro'yuna, tujuan organisasi ini adalah diantaranya, memberikan bekal keterampilan jurnalistik mahasiswa agar mampu memfungsikan kebebasan mimbar secara kreatif, konstruktif, inovatif dan bertanggung jawab; membangun integrasi terhadap kampus dengan selalu menjunjung tinggi idealisme mahasiswa (AD/ART LPM Ro’yuna 2012/2011).

Untuk mewujudkan tujuan tersebut, LPM Ro'yuna menerbitkan produk jurnalistik berupa buletin yang bernama BuletinEg@liter, dengan moto-Pas untuk Mahasiswa Kritis." Beberapa rubrik yang disajikan BuletinEg@liter adalah sapa redaksi, surat pembaca, laporan utama, laporan khusus, metro kampus, opini, dan sastra. Buletin ini juga menerima tulisantulisan dari mahasiswa yang tidak aktif di organisasi LPM Ro'yuna. Dibandingkan dengan produk-produk jurnalistik di dua atau tiga UIN sebelumnya, tampaknya produk jurnalistik Ro'yuna kualitasnya masih sederhana, yakni dengan kualitas cetakan yang biasa-biasa saja dalam kertas HVS putih meski sudah tampak ada yang berwarna.

LPM Ro’yuna dengan buletin Eg@liter-nya juga menyediakan sajian informasi dan berita melalui internet, meskipun dengan wadah blogspot - tidak seperti lembaga pers mahasiswa di UIN sebelumnya yang sudah tidak lagi blogspot. Sajian rubrik dalam media yang ditampilkan blog sama seperti rubrik-rubrik yang disajikan dalam edisi tercetak. 
Gambar 12. Tampilan Blog buletin Eg@liter LPM Ro’yuna LEMBAGA PERS MAHASISWA RO'YUNA

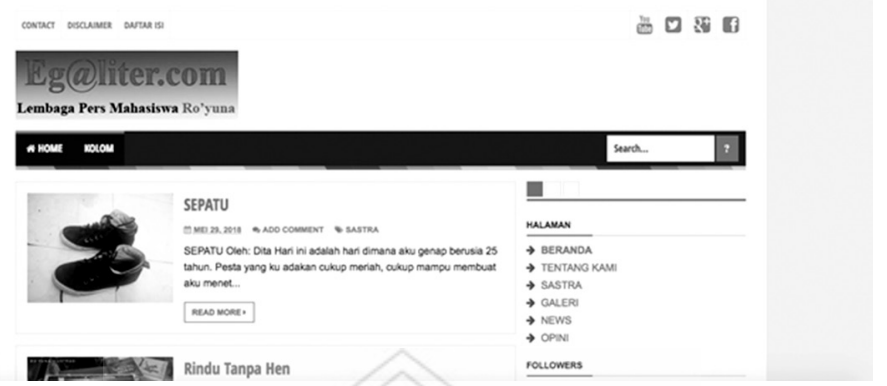

Sumber: Foto koleksi peneliti (Agus Iswanto)

UIN Antasari Banjarmasin memiliki LPM yang bernama -LPM Sukma." Sukma adalah singkatan dari -suara kritis mahasiswa." LPM Sukma berdiri pada 24 Mei 1998. Seperti organisasi pers pada umumnya, LPM Sukma juga bertujuan untuk mengekspresikan suara kritis dengan menyajikan produk jurnalistik berupa tabloid atau majalah dinding universitas. Selain menyajikan produk jurnalistik, sebagai upaya meningkatkan kapasitas personal organisasi, LPM Sukma juga mengadakan beberapa kegiatan pelatihan yang memberikan keterampilan dalam dunia jurnalistik seperti teknik reportase dan menulis opini. Bahkan, tidak hanya kepada aktivis organisasi internal, workshop atau pelatihan juga terkadang diberikan kepada mahasiswa-mahasiswa lainnya yang tidak aktif di dalam organisasi. 


\section{Gambar 13.Tampilan Web LPM Suka UIN Antasari}

Banjarmasin

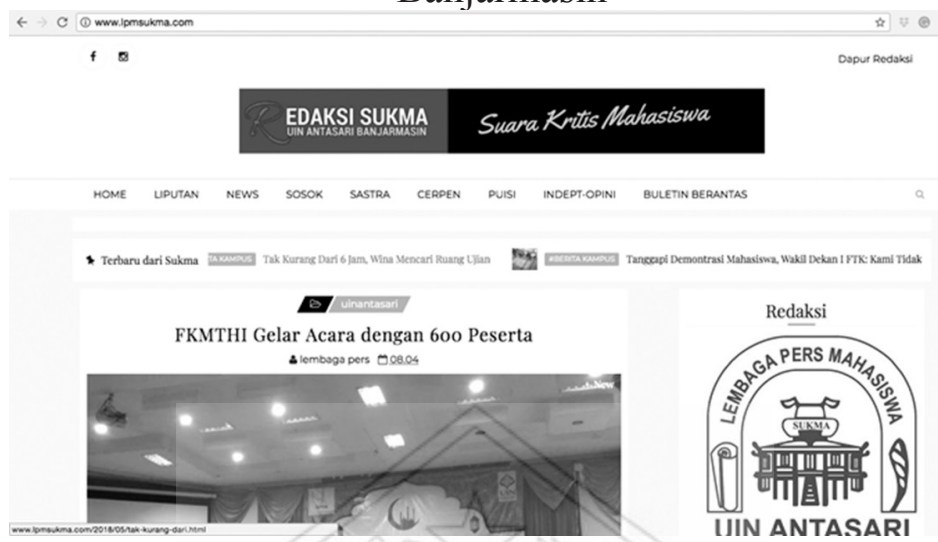

Sumber: Foto koleksi peneliti (Agus Iswanto)

Melihat berbagai produk jurnalistik mahasiswa yang telah disajikan di atas, tampak bahwa mahasiswa yang tergabung dalam organisasi LPM memiliki motivasi literasi intrinsik. Tidak saja bagi mahasiswa yang tergabung di dalam organsiasi, mahasiswa-mahasiswa lain yang tidak tergabung dalam organisasi pers mahasiswa tetapi menyumbangkan karya tulisannya juga dapat dikategorikan sebagai mahasiswa yang memiliki motivasi intrinsik dalam literasi, baik literasi menulis maupun membaca.

Tampak, dalam tulisan-tulisan yang disajikan mereka mengungkapkan ide, perasaan dan pengetahuan yang dimiliki kepada khalayak. Mereka juga ingin terlibat dalam penyelesaian permasalahan sosial. Hal ini tentu memperjelas bahwa literasi adalah suatu praktik sosial yang sesuai konteks dan kebutuhan. Literasi memungkinkan seseorang untuk berpartisipasi dalam permasalahan yang muncul di tengah masyarakat (Dewayani dan Retnaningdyah, 2017: 196). Menjadi literat bermakna bahwa seseorang, 
termasuk mahasiswa, mampu menggunakan potensinya untuk berpartisipasi secara optimal dalam komunitas dan lingkungan sosialnya.

Hal tersebut tampak sebagaimana kalau dicermati dalam beberapa tulisan di berbagai produk jurnalistik yang telah dikemukakan, misalnya dalam sebuah tulisan yang berjudul -Resiko Eksploitasi Lingkungan dalam Pariwisata." Tulisan ini ditulis oleh seorang mahasiswa Ilmu Komunikasi di UIN Sunan Kalijaga, diterbitkan dalam media online Arena. Tulisan ini menekankan kepentingan perhatian terhadap resiko atau akibat yang dapat muncul karena eksploitasi lingkungan dalam industri pariwisata (https://pmarena.com/2018/07/10/ risiko-eksploitasi-lingkungan-dalam-pariwisata/). Ada juga tulisan yang terkait dengan masalah sosial-ekonomi seperti tulisan yang berjudul-Menimbang Keadilan Pengadaan Tanah Pembangunan untuk Kepentingan Umum” (https:// lpmarena.com/2018/07/17/menimbang-keadilan-pengadaantanah-pembangunan-untuk-kepentingan-umum/).Tidak hanya terkait dengan masalah-masalah sosial-lingkungan dan sosial-ekonomi, masalah-masalah sosial-keagamaan pun menjadi sorotan para penulis dalam produk jurnalistik mereka, khususnya melalui tulisan opini, misalnya, dalam tulisan yang berjudul -Agama dan Munculnya Kelas Sosial Baru” (https://lpmarena.com/2018/04/25/agama-dan-munculnyakelas-sosial-baru/).

Begitu juga di lembaga-lembaga pers mahasiswa yang lain, tulisan-tulisan yang mencerminkan praktik literasi mahasiswa juga tampak dalam produk-produk atau artefakartefak literasinya dalam media online maupun maupun cetak yang dikelola oleh lembaga pers mahasiswa. Seperti di SKM Amanat, ada banyak tulisan mahasiswa yang terkait 
dengan sosial-politik, sosial-ekonomi dan sosial-keagamaan. Tulisan tentang sosial-politik tampak dalam sebuah tulisan yang berjudul -Bhineka Tunggal Ika dalam Bayang-Bayang Pilkada." Tulisan ini mengajukan kepentingan memperkuat gagasan Bhineka Tunggal Ika yang pudar hanya karena konflik dalam perbedaan pilihan dalam Pemilihan Kepala Daerah (https://skmamanat.com/bhineka-tunggal-ika-dalam-bayangbayang-pilkada/). Tulisan lain tentang sosial-kebudayaan berjudul -Menyelematkan Bahasa Ibu." Tulisan mengajukan gagasan untuk menyelamatkan bahasa ibu (bahasa lokal) sebagai sebuah identitas bangsa (https://skmamanat.com/ menyelamatkan-bahasa-ibu/). Tulisan tentang sosialkeagamaan juga tampak menjadi perhatian, seperti tulisan dengan judul -Radikalisme Agama di Perguruan Tinggi."

Tulisan-tulisan opini di lembaga pers mahasiswa di UIN Sunan Ampel juga menunjukkan hal yang serupa. Tulisantulisan terkait dengan persoalan-persoalan sosial yang sedang menjadi isu di masyarakat, seperti tulisan yang berjudul -Turn Back Hoax: Menangkal Hoax dan Gerakan Literasi." Tulisan ini mengajukan betapa penting sebuah kerjasama antar berbagai pihak dalam memerangi hoax dengan menggerakan literasi agar lebih memahami dan kritis terhadap informasi yang diterima (http://www.mediasolidaritas.com/turn-backhoax-menangkal-hoax-dan-gerakan-literasi-media/).

Para aktivis lembaga pers mahasiswa, ternyata tidak saja menyalurkan gagasannya melalui media-media di lingkungan kampusnya atau yang diterbitkan oleh lembaga pers mahasiswa terkait. Sebagian mahasiswa yang aktif tersebut juga menulis di media-media lain untuk mencurahkan gagasan dan kegelisahan mereka. Sebagai contoh, di UIN Mataram, salah seorang mahasiswi yang aktif di lembaga 
pers mahasiswa beberapa kali menulis di media massa lokal dan nasional, baik cetak maupun online. Bahkan, sang mahasiswi ini pernah mendapatkan juara dalam sebuah lomba kepenulisan yang diselenggarakan oleh sebuah media online, yakni www.qureta.com. Hasil tulisan yang memenangi lomba ini kemudian diterbitkan oleh media tersebut secara online. Judul tulisan tersebut adalah -Toleransi Atas Nama Cinta." Tulisan ini mengisahkan tentang laki-laki dan perempuan yang berbeda agama saling mencintai tetapi tidak direstui kedua orang tua. Hal tersebut mengakibatkan permasalahan yang semakin rumit di masa selanjutnya bagi si anak perempuan dan orang tuanya. Ide utama yang ingin disampaikan sang penulis - yang merupakan mahasiswi iniadalah bahwa melarang orang menikah dengan kekasihnya yang berbeda agama akan mengakibatkan sesuatu yang lebih buruk daripada merelakannya (https:/www.qureta.com/post/ toleransi-atas-nama-cinta-2).

Gambar 14. Tampilan Tulisan Aktivis Pers Mahasiswa di Media Lain (qureta.com)

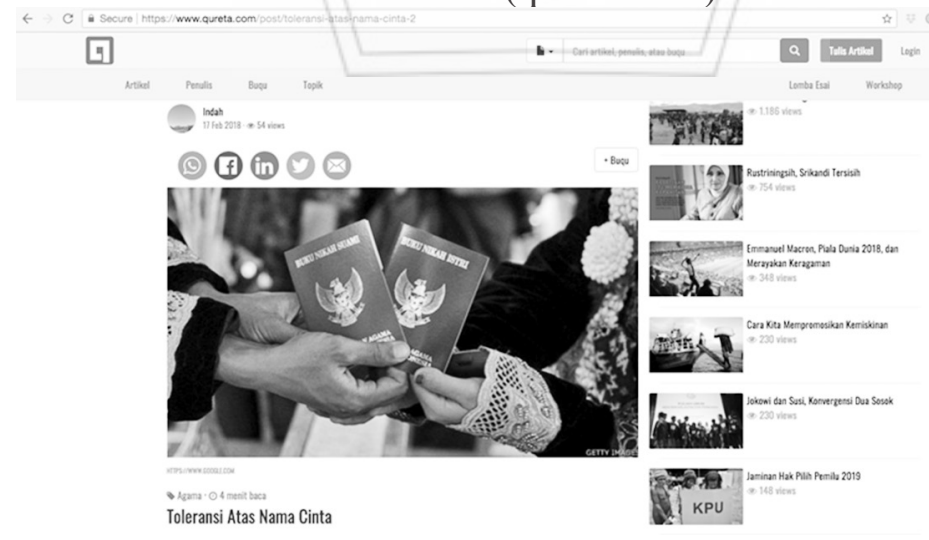

Sumber: Koleksi peneliti (Agus Iswanto)

Menurut pengakuan penulis artikel opini tersebut, 
sebut saja namanya Indah (sesuai nama yang dituliskan dalam media tersebut), tulisan tersebut lahir berdasarkan pengalaman dirinya yang hidup dalam komunitas yang beragam, tetapi selalu harmonis. Keharmonisan itu terganggu karena kasus pacaran dan rencana pernikahan karena alasan perbedaan agama dalam satu kampung yang sama. Hasilnya, ini berdampak pada hubungan sosial antar warga kampung yang berbeda-beda tersebut. Awalnya harmonis lalu menjadi hubungan sosial yang curiga (wawancara dengan Indah, mahasiswi UIN Mataram, 24 Mei 2018).

Indah menjadi contoh bahwa aktivitas kepenulisan di lembaga pers mahasiswa membawa dirinya untuk aktif menulis di media-media lain di luar lembaga pers. Sebagaimana diakui, Indah sebetulnya mulai lebih aktif dalam hal kepenulisan sejak kuliah dan aktif dalam lembaga pers mahasiswa. Menurutnya, sebetulnya kesenangan membaca dan menulis sudah tumbuh sejak di Sekolah Menengah Pertama (SMP). Berawal dari menulis diari harian dan membaca buku (novel) Negeri 5 Menara. Selain itu, ada juga dorongan dari orang tua untuk membaca dan menulis (wawancara dengan Indah, mahasiswi UIN Mataram, 1 Juni 2018).

Demikian, beberapa lembaga pers mahasiswa yang memiliki sejumlah media jurnalistik. Beberapa media yang dikemukakan baru pada media-media yang diterbitkan oleh lembaga pers mahasiswa di tingkat universitas, belum mengurai media mahasiswa yang diterbitkan oleh lembagalembaga pers mahasiswa di tingkat fakultas. Sebagaimana ditemui dalam peneltian ini, beberapa fakultas juga memiliki media informasi yang diterbitkan oleh lembaga pers mahasiswa di tingkat fakultas. Misalnya, di Fakultas Dakwah 
dan Komunikasi UIN Sunan Ampel terdapat lembaga pers mahasiswa yang bernama LPM Ara Aita dengan majalahnya yang bernama Ara Aita: Wahana Penyalur Aspirasi dan Kreasi Mahasiswa. Lembaga pers mahasiswa juga terdapat di Fakultas Syariah dan Hukum kampus UIN Sunan Ampel. Lembaga pers ini juga memiliki media majalah yang bernama LPM Ar-Risalah.

Selain itu, yang penting dicermati adalah adaptasi pers mahasiswa di tengah dunia digital. Pers-pers mahasiswa di tingkat universitas, bahkan di tingkat fakultas sudah menggunakan kecanggihan teknologi informasi dengan membuat portal-portal online untuk menyajikan berita dan tulisan-tulisan. Hal tersebut rupanya sudah disadari oleh mahasiswa aktivis pers sendiri. Seperti yang terjadi di beberapa lembaga pers mahasiswa di UIN Walisongo, sebagaimana dilaporkan dalam salah satu produk jurnalistik mahasiswa, bulletin El-Manhaj, dunia pers mahasiswa UIN Walisongo terlihat mulai beradaptasi di tengah era milenial. Langkah tersebut adalah bagian dari inovasi agar tidak tergerus zaman. Meskipun tidak banyak dukungan dana dari birokrasi kampus untuk pers online ini, namun dengan kreativitas para aktivis pers mahasiswa setempat, portal berita online tetap terwujud (Buletin El-Manhaj, edisi XXV, 2017: 6-8). Hal ini tentu berlaku di kampus-kampus yang lain. Rupanya, mahasiswa lebih cepat beradaptasi dengan perkembangan teknologi informasi ketimbang birokrasi kampus itu sendiri. Produksi informasi dan pengetahuan yang dilakukan mahasiswa sudah memanfaatkan kecanggihan dan kecepatan internet. Produksi dan informasi ini adalah bagian dari cara penyampaian ide atau gagasan mahasiswa.

Produk jurnalistik yang diterbitkan oleh lembaga-lembaga 
pers mahasiswa mampu menjadikan wadah penyampaian ide atau gagasan mahasiswa. Berbagai produk jurnalistik tersebut, terutama kalau melihat tulisan-tulisan opini, adalah suatu artefak literasi yang menunjukkan telah terjadinya praktik literasi di kalangan mahasiswa melalui wadah pers mahasiswa. Selain itu, lembaga-lembaga pers mahasiswa juga menjadi ajang belajar para aktivis untuk lebih aktif menulis di media-media yang lain. Dengan demikian pers mahasiswa dapat dikatakan sebagai komunitas literasi yang ada di dalam kampus. Mungkin lembaga inilah satu-satunya yang secara struktural dapat menggerakan praktik literasi mahasiswa secara luas di masing-masing kampus.

\section{Komunitas Diskusi dan Kepenulisan}

Mahasiswa-mahasiswa yang giat mempraktikan literasi tidak hanya mahasiswa-mahasiswa yang aktif atau terlibat dalam lembaga pers mahasiswa. Ada beberapa mahasiswa yang justru giat membaca dan menulis melalui komunitaskomunitas baca dan kepenulisan di luar lembaga pers mahasiswa. Komunitas-komunitas ini biasanya didirikan di luar struktur organisasi kampus, dan biasanya atas inisiatif dari kalangan mahasiswa sendiri. Komunitas ini bisa juga hanya ada dalam sebuah kampus tertentu, atau memang bisa juga sebagai sebuah komunitas lintas kampus yang keberadaannya justru dalam skala nasional.

Komunitas-komunitas ini juga dapat terkait dengan organisasi-organisasi ekstra yang ada di sekitar kampus, seperti Himpunan Mahasiswa Islam (HMI), Pergerakan Mahasiswa Islam Indonesia (PMII), Kesatuan Aksi Mahasiswa Muslim Indonesia (KAMMI) dan organisasiorganisasi ekstra lainnya. Selain itu, komunitas-komunitas 
ini bisa juga berupa komunitas kajian atau studi yang digagas oleh para mahasiswa di sebuah program studi tertentu.

Sebagai contoh, di UIN Sunan Kalijaga Yogyakarta, ada sebuah kelompok yang bernama -Mobura" (-Moco buku rame-rame"), yang berarti - membaca buku bersama-sama." Seorang mahasiswi mengatakan tentang -Mobura" ini:

Secara umum kalau praktik gerakan literasi dimulai sejak tahun 2014, saya sendiri melalui prodi (program studi) Pengembangan Masyarakat. Kami membawa satu kelompok mahasiswa untuk praktikum. Praktik di daerah saya sendiri sampai sekarang sampai ada taman bacaan masyarakat. Taman bacaan masyarakat desa adalah hasil praktikum selama 1 tahun. Ada 7 orang kebetulan di rumah saya sendiri, lokasi perumahan masih banyak yang kosong. Penyadaran mungkin yang butuh waktu lama. Mahasiswa terlibat mulai dari penyadaran. Dari tahun 2018 terbangun bangunan mungil suatu gedung taman bacaan masyarakat (Siti Aminah, 24 Mei 2018).

Jadi, "Mobura" adalah sebuah komunitas literasi yang digagas oleh para mahasiswa di UIN Sunan Kalijaga untuk menggerakan literasi, baik kepada sesama mahasiswa maupun kepada masyarakat secara luas. Kutipan di atas adalah salah satu hasil gerakan Mobura yang di lakukan di masyarakat. Dengan gerakan ini mereka mengupayakan berdirinya taman bacaan di lingkungan masyarakat.

Komunitas kepenulisan yang digagas oleh komunitas program studi ditemukan di UIN Mataram. Misalnya di Program Studi Pendidikan Bahasa Arab pada Fakultas Tarbiyah dan Keguruan, terdapat komunitas yang disebut dengan "Komunitas Pena Kecil." Komunitas ini berdiri pada tahun 2017. Salah seorang pengurusnya mengatakan, kebanyakan mahasiswa yang aktif di komunitas ini memiliki kemampuan menulis fiksi. Setiap minggu, para anggota harus memenuhi "majalah dinding" (mading) dengan karya tulis, 
baik puisi, cerpen, artikel maupun kutipan-kutipan motivasi. Para anggota komunitas ini sepakat bahwa nantinya tulisantulisan yang dipasang di majalah dinding ini akan diterbitkan dalam sebuah buku (wawancara dengan Nurma, 29 Mei 2018).

Komunitas Kepenulisan biasanya juga tergabung di dalam komunitas ilmiah atau diskusi dalam beberapa Unit Kegiatan Mahasiswa (UKM) di kampus. Misalnya UKM Cendikia di UIN Antasari Banjarmasin. Kegiatan UKM ini adalah kegiatan-kegiatan ilmiah. Sebagaimana disebutkan dalam visinya, UKM Cendekia menjadi wadah kegiatan mahasiswa dalam bidang kajian interdisipliner dan pembinaan diri yang ilmiah, moderat dan Islami. Adapun misinya adalah; (1) melakukan pengkajian dan penelitian dalam berbagai disiplin ilmu melalui pendekatan/interdisipliner; (2) membina anggotanya menjadi mahasiswa yang memiliki integritas kepribadian, akhlak mulia, jiwa kepemimpinan, dan kompetensi akademis. Oleh karena itu tujuan UKM Cendekia adalah: (1) mencetak kader-kader akademis yang profesional di bidangnya; (2) menjadi dinamisator kehidupan ilmiah di kampus; (3) menjadi pusat pengkajian dan penelitian ilmiah interdisipliner mahasiswa; (4) berperan serta dalam mewujudkan tri dharma perguruan tinggi (http://antasaricendekia.blogspot.com/). Praktiknya, UKM ini melakukan kajian buku, yakni setiap anggota diharuskan membaca buku, kemudian didiskusikan bersama-sama anggota yang lain. Selain itu aktifitas pengkajian dan penelitian yang dilakukan juga mensyaratkan anggota untuk membaca rujukan dan menuliskan dalam sebuah laporan penelitian (wawancara dengan Pembantu Rektor III, 25 Mei 2018).

Kegiatan literasi yang berbasiskan pada komunitas 
diskusi di UKM juga terdapat di UIN Walisongo Semarang, seperti UKM KSMW (Kelompok Studi Mahasiswa Walisongo). Unit kegiatan ini bergerak dalam kajian lintas disiplin keilmuan dan riset (https://skmamanat.com/ini16-ukm-tingkat-universitas-di-uin-walisongo/). Kolompok ini juga memiliki sebuah website yang mempublikasikan beberapa hasil tulisan para aktivisnya. Tulisan-tulisan yang dipublikasikan biasanya telah didiskusikan di seputar para aktivis. Tulisan-tulisan tersebut termuat dalam kolom artikel. Misalnya, ada sebuah tulisan tentang hubungan media dan politik, tentang persoalan paradigma pembangunan, serta kritik terhadap ideologi khilafah. Jika dicermati, sesuai dengan tujuan komunitas ini, maka tulisan-tulisan yang tersajikan memang bersifat interdisipliner, tidak hanya terkait dengan kajian Islam, tetapi juga masalah-masalah sosial yang terjadi di masyarakat.

Gambar 15. Tampilan Website milik Komunitas Studi

Mahasiswa Walisongo

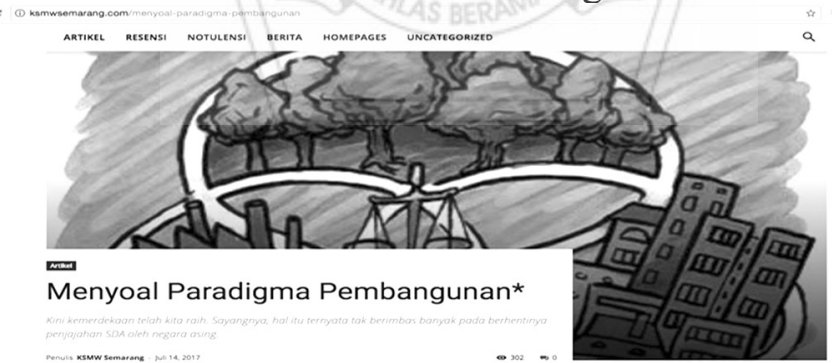

Sumber: Koleksi peneliti (Agus Iswanto)

Selain artikel, ada juga tulisan-tulisan yang berupa notulensi hasil sebuah diskusi, seperti tulisan notulensi yang berjudul "Notulensi Pemikiran M. Abduh." Diskusi ini dilakukan di rumah salah seorang dosen, yang biasanya sang dosen memberikan sejumlah pandangan dalam diskusi 
tersebut. Penulisan notulensi penting artinya sebagai sebuah praktik literasi yang kontekstual. Notulensi tersebut menggambarkan proses literasi berlangsung di tengah-tengah komunitas. Diskusi tidak dapat berjalan dengan baik tanpa pengetahuan yang dimiliki oleh masing-masing perserta diskusi, dan pengetahuan tersebut tentu saja didapat dengan membaca. Jadilah, aktivitas diskusi memantik para aktivis untuk membaca tentang tema yang akan didiskusikan.

Komunitas diskusi mahasiswa yang erat hubungannya dengan praktik literasi juga terjadi di kalangan organisasi ekstra mahasiswa. Hal tersebut misalnya tampak dalam organisasi Pergerakan Mahasiswa Islam Indonesia (PMII) atau Himpunan Mahasiswa Islam (HMI), Keluarga Mahasiswa Nahdlatul Ulama (KMNU), Ikatan Mahasiswa Muhammadiyah (IMM) di beberapa kampus yang diteliti. Organisasi PMII di UIN Sunan Kalijaga Yogyakarta misalnya, terdapat sebuah kegiatan diskusi Komunitas Asiyah di PMII UIN Sunan Kalijaga (Putra, 2017). Kegiatan diskusi tersebut menjadi ajang olah pikir para anggota aktivis. Setiap diskusi selalu menghadirkan tulisan sebagai bahan diskusi.

Keluarga Mahasiswa Nahdlatul Ulama (KMNU) UIN Sunan Kalijaga Yogyakarta, misalnya mengkampanyekan untuk melawan radikalisme dengan gerakan literasi, yakni dengan menulis konten-konten Islam yang damai. Salah satu majalah yang banyak memuat aktivis KMNU adalah majalah Bangkit yang diterbitkan oleh Pengurus Wilayah Nahdlatul Ulama (PWNU) Yogyakrta. Majalah Bangkit terbit sekitar tahun 1979 pada masa KH. Ali Maksum. Pada masa awal yaitu tahun 1979 sampai tahun 2015-an terbit dengan versi cetak, akan tetapi sekitar tahun 2016 mulai terbit dengan versi online. Hal yang penting menjadi perhatian dalam konteks 
penelitian ini adalah, sebagian besar pengelola majalah ini adalah mahasiswa UIN Sunan Kalijaga yang aktif pada organisasi NU. Isi dari majalah ini adalah masalah-masalah keagamaan, laporan utama (berita-berita utama dari majalah tersebut), berisi kolom pendidikan, kolom pesantren, Aswaja, bahsul Masail, teks khutbah, kolom tafsir, tasawuf, lintas nusantara, kolom tokoh, inspirasi dan refleksi (wawancara dengan mahasiswa aktivis Majalah Bangkit, 20 Mei 2018).

Tulisan-tulisan mahasiswa yang dimuat oleh majalah Bangkit, selain masalah-masalah keislaman, juga terkait dengan masalah-masalah sosial. Misalnya tulisan tentang masalah keislaman berjudul "Membumikan Aswaja di Negeri Paman Sam" dalam majalah Bangkit edisi Maret 2017. Tulisan ini tentang nilai-nilai Islam Aswaja yang berkembang di Nusantara yang digunakan untuk membaca realitas peradaban lain. Tulisan ini merupakan hasil wawancara dengan Ahmad Rafiq, wakil sekretaris PWNU DIY yang pernah berkiprah di Amerika. Tulisan lainnya tentang masalah sosial berjudul "Pernikahan Dini Bukan Solusi Pergaulan Bebas." Tulisan ini sebetulnya tentang literasi masalah sehari-sehari yang biasa dihadapi masyarakat. Tulisan ini juga berdasarkan hasil wawancara dari seorang tokoh dari Pusat Studi Wanita. Jadi, dengan tulisan-tulisan ini tampak komunitas diskusi melahirkan praktik literasi di berbagai bidang sosial, sehingga literasi adalah bagian dari sebuah praktik sosial. 
Gambar 16. Kelompok mahasiswa yang sedang diskusi

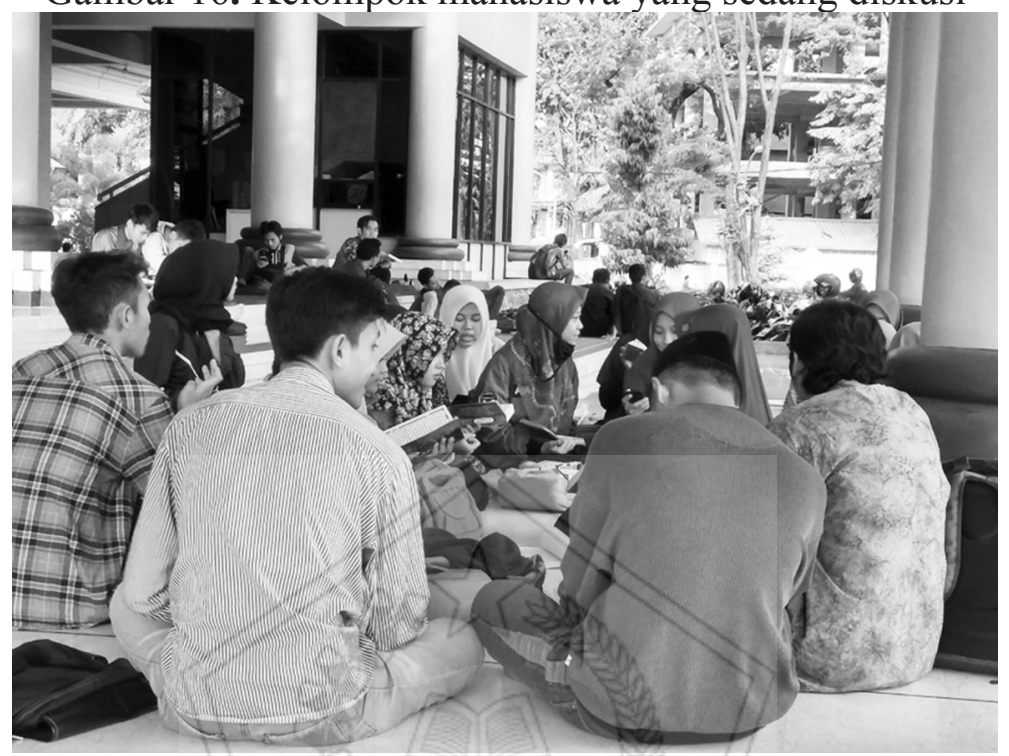

Sumber: Koleksi peneliti (Moch Lukluil Maknun)

\section{Kelompok Penulis "Mandiri"}

Dunia yang global dan termediasi oleh instrumen digital kini semakin memudahkan orang dalam mempraktikan literasi, baik membaca maupun menulis, meskipun tidak memiliki basis komunitas, baik komunitas pers mahasiswa maupun komunitas diskusi sebagaimana telah dipaparkan. Inilah yang kemudian dapat disebut sebagai kelompok mahasiswa yang mempraktikan literasi membaca dan menulis secara mandiri. Kelompok ini melakukan praktik literasi secara mandiri tanpa ketergantungan dengan komunitaskomunitas yang ada di sekelilingnya. Biasanya, mereka sudah sejak dini mempraktikan literasi karena dorongan lingkungan keluarganya atau lingkungan pendidikan sebelumnya. Misalnya seperti yang dilakukan oleh beberapa mahasiswi 
UIN Mataram, Yenita, Nurul Aini dan Tani.

Nurul Aini misalnya. Dia beberapa kali menulis di media massa lokal di Lombok sejak SMA. Dia juga pernah memenangi lomba menulis. Tulisan yang memenangi lomba tersebut adalah opini tentang hari santri. Tema-tema yang diminati adalah tentang toleransi dan Islam. Lain lagi dengan Yenita. Dia banyak menulis dan membaca sejak sebelum kuliah di UIN Mataram. Dia menulis karya-karya fiksi di sebuah situs komunitas pembaca dan penulis yang menampilkan karya-karya dalam berbagai genre, fiksi, nonfiksi maupun puisi, yakni www.wattpad.com.

Gambar 17. Contoh Tampilan Wattpad

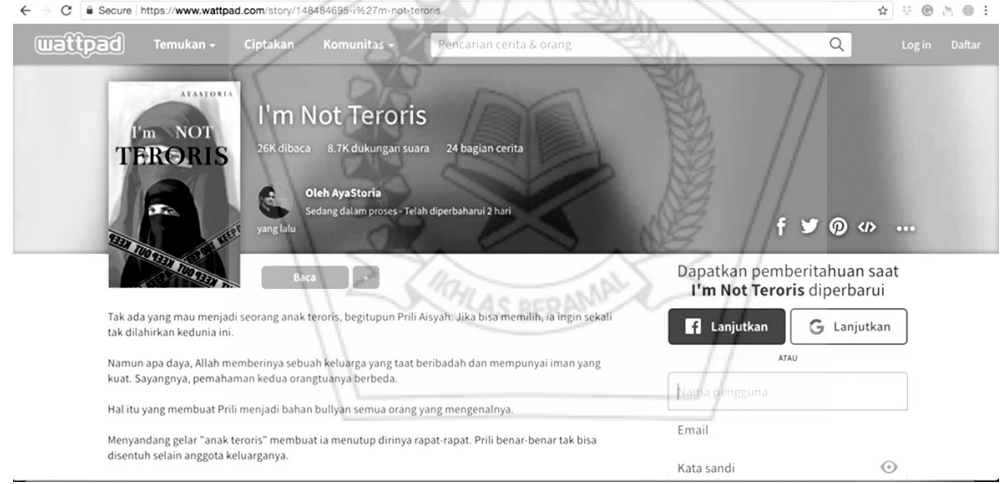

Sumber: Koleksi peneliti (Agus Iswanto)

Selain fiksi, kelompok mahasiswa yang mengembangkan kemampuan menulis secara mandiri memilih bidang kepenulisan dalam berbagai tema non fiksi. Di bawah ini salah satu karya seorang mahasiswi yang mengembangkan kemampuan menulisnya secara mandiri. Tulisan ini ditulis oleh Nurul Aini, seorang mahasiswi Jurusan Pendidikan Bahasa Inggris UIN Mataram. Tulisannya tentang kerukunan dan toleransi antar umat beragama yang terancam karena ulah segelintir orang. 
Indonesia adalah negara kepulauan dan memiliki berbagai suku, ras, budaya dan berbagai macam agama yang diperbolehkan berkembang di Indonesia. Etnik atau suku bangsa biasanya memiliki berbagai kebudayaan yang berbeda satu dengan yang lainnya. Indonesia memiliki lebih dari 300 suku bangsa, di mana masingmasing memiliki kebudayaan yang berbeda- beda antara satu dengan yang lain. Selain itu masing- masing suku bangsa memiliki norma sosial yang mengikat masyarakat di dalamnya agar taat dan melakukan segala yang tertera di dalamnya. Dari satu sisi perbedaan - perbedaan yang dilihat dan dinilai sebagai kekayaan bangsa dimana para penganut agama yang berbeda bisa saling menghargai atau menghormati.

Kerukunan dan toleransi antar sesama manusia, baik yang beragama maupun yang tidak beragama, merupakan tuntutan kebutuhan dan kewajiban kemanusiaan dari setiap orang. Kerukunan dan toleransi antar umat beragama merupakan konsekuensi dari hakekat kemanusiaan kita. Oleh sebab itu ada orang yang merusakkan atau menolak kerukunan berarti sama dengan ia merusakkan dan menolak kemanusiaan. Menurut data yang di peroleh penulis tahun lalu dua kasus intoleransi paling buruk pada tahun 2015 adalah pembakaran rumah ibadah di Tolikara dan pembakaran gereja di Aceh Singkil. Dan yang tidak terlupakan aksi yang baru- baru ini terjadi, demo 4 november 2016 itu masih membekas di ingatan masyarakat Indonesia pastinya, kasus tersebut membuat umat Muslim merasa di hina kepercayaannya oleh gubernur nonaktif (Ahok). Apakah penyebab terjadinya masalah di atas dan bagaimana solusi untuk mengahadapi maslah tersebut. Lalu bagaimana dengan Sam Aliano yang menginginkan gubernur anis baswedan menghapuskan undangundang yang mengatur penghapusan diskriminasi yaitu undangundang No 40 tahun 2008? (Aini, 2018).

Hal yang penting diberi catatan adalah, klasifikasi tiga kelompok mahasiswa penulis di atas sebetulnya bukan sebuah klasifikasi yang statis. Masing-masing mahasiswa di dalam kelompok tersebut terkadang menempati dua klasifikasi sekaligus, terkadang mahasiswa yang aktif di sebuah komunitas diskusi, pada saat yang sama pula aktif dalam organsasi pers mahasiswa. Hal tersebut dikemukakan 
salah seorang alumnus aktivis pers mahasiswa di UIN Walisongo (T, 24 Juli 2018). Menurutnya, tidak bisa secara statis memisahkan antara tiga kategori kelompok tersebut, sebab nyatanya banyak mahasiswa yang aktif di dalam berbagai komunitas yang kesemuanya mendukung praktik literasi mereka. Titik singgung ketiga kelompok tersebut dapat digambarkan sebagai berikut.

Gambar 18. Klasifikasi 3 Komunitas Literasi Mahasiswa

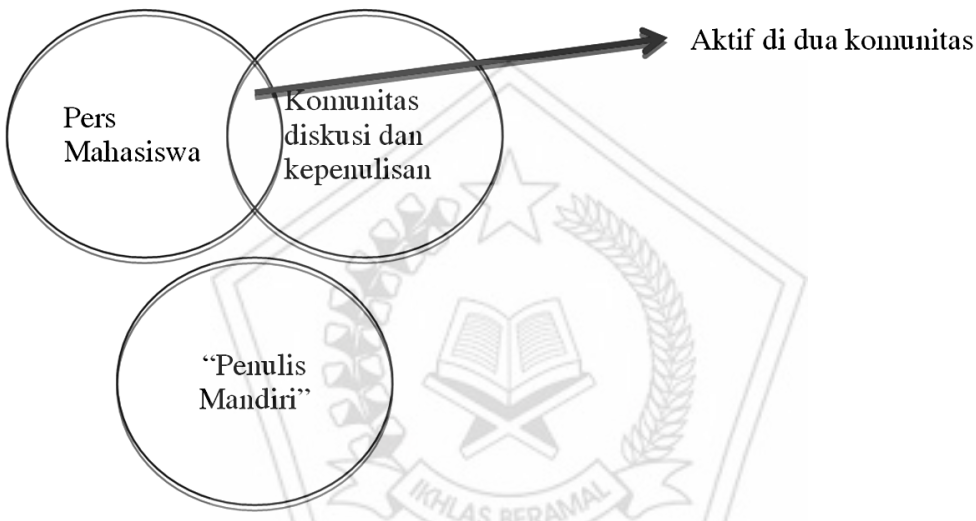

Akhirnya, komunitas literasi ini penting dikemukakan dalam konteks praktik literasi mahasiswa. Komunitas yang sangat erat kaitannya dengan praktik literasi mahasiswa di kampus setidaknya dapat membuka potensi bagi gerakan literasi yang selama ini dikeluhkan masih rendah. Komunitas literasi biasanya tumbuh dan berkembang karena kesukaan dan kecintaan para pegiatnya terhadap dunia literasi (membaca dan menulis) serta keinginan berbagi rasa suka dan cintanya tersebut kepada publik yang lebih luas (https:// theconversation.com/semangat-membaca-di-pelosokmenantang-anggapan-minat-baca-rendah-82023). Potensi ini perlu dikembangkan agar dapat menambah daya ungkit praktik literasi di kalangan mahasiswa yang lebih luas. 
Sebagaimana yang telah dijelaskan, generasi milenial banyak menjadikan peer group sebagai referensi dalam menentukan aktivitas yang dilakukan oleh mereka.

Perhatian birokrasi kampus biasanya hanya pada pers mahasiswa dan komunitas diskusi, itu pun yang masuk pada ranah aktivitas intra kampus. Skema pendanaan biasanya mengalir melalui pembinaan kegiatan mahasiswa yang berada di unit-unit kegiatan mahasiswa (UKM). Bisa dipahami karena memang secara struktural, unit-unit ini berada dalam pembinaan kampus. Pendanaan itu pun biasanya jauh dari apa yang dibutuhkan oleh masing-masing unit. Pendanaan aktivitas-aktivitas mahasiswa yang terkait dengan literasi semestinya juga memperhatikan skema kebutuhan bagi literasi di era digital. Memperhatikan pentingnya literasi dalam konteks mahasiswa dalam era milenial seperti ini, birokrasi kampus dan lembaga struktural di atasnya (Kementerian Agama dan Kementerian Riset, Teknlogi dan Perguruan Tinggi) semestinya lebih mendukung dengan berbagai bentuk program yang lebih memaksimalkan aktivitas aktivis literasi kampus berbasis teknologi informasi dan digital, baik melalui komunitas-komunitas yang ada maupun komunitas yang perlu dibentuk. 


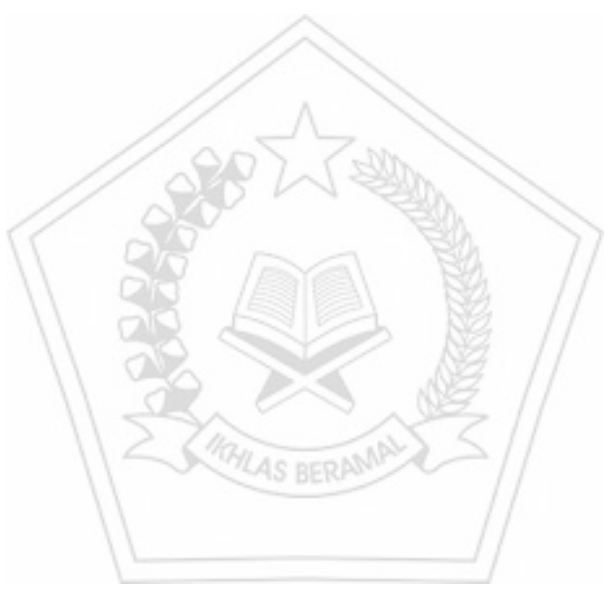




\section{BAB V \\ PENUTUP}

\section{Simpulan}

\section{Infrastruktur Literasi}

Masing-masing UIN telah menyediakan infrastruktur literasi dalam bentuk perpustakaan dengan berbagai variasi keunggulan dan kelemahan, baik dari segi koleksi, gedung dan keragaman layanan. Hal tersebut terkait konteks lokal di masing-masing kampus, baik konteks kebijakan internal maupun kondisi sumber daya manusia yang mendukung pemenuhan perpustakaan sebagai pemenuhan infrastruktur literasi.

Universitas Islam Negeri (UIN), sebagai wujud integrasi keilmuan, telah memberikan konteks cita-cita ideal bagi pengembangan multiliterasi dalam proses produksi ilmu pengetahuan yang dilakukan. Namun, cita-cita ideal tersebut di satu sisi belum terhubung dengan konteks lain dari subyek yang memanfaatkan layanan pendidikan UIN, yakni mahasiswa generasi milenial. Infrastruktur literasi belum sejalan dengan paradigma integratif dan konsep multiliterasi yang seharusnya dikembangkan dalam konteks layanan pendidikan di abad ke-21. 
Layanan literasi dalam berbagai perpustakaan tampak telah mengadaptasi perkembangan teknologi informasi terkini, tetapi pemanfaatannya belum maksimal. Selain itu, beberapa kampus belum dapat memenuhi harapan layanan perpustakaan yang dikehendaki mahasiswa sebagai generasi milenial. Beberapa partisipan kesulitan mendapatkan koleksi bacaan terbaru baik yang ada kaitannya dengan kuliah maupun yang tidak. Karena itu, dapat dipahami jika mereka kebanyakan $(48,96 \%)$ hanya sekali mengunjungi perpustakaan dalam waktu satu minggu, bahkan ada (sebanyak $15,89 \%$ ) yang tidak pernah sama sekali mengunjungi perpustakaan dalam waktu seminggu. Hanya $4,87 \%$ yang setiap hari mengunjungi perpustakaan. Meskipun demikian, kebanyakan mereka memandang perpustakaan seharusnya nyaman untuk membaca. Selain itu, mereka berharap di perpustakaan partisipan tidak hanya membaca dan meminjam buku, tetapi juga digunakan untuk mengerjakan tugas dan mengakses internet gratis.

Perpustakaan kampus belum banyak menyediakan koleksi bacaan yang menyenangkan sesuai selera generasi milenial (seperti cerita-cerita fiksi). Bacaan-bacaan yang tersedia lebih banyak bacaan-bacaan yang membosankan untuk tujuan perkuliahan semata. Hal tersebut tampak dari banyaknya pernyataan mahasiswa yang menyatakan bahwa, hal yang paling menghambat mereka untuk membaca adalah bacaan yang membosankan dan tidak menemukan bacaan yang menyenangkan.

Keberadaan perpustakaan masih sebatas menjadi pemenuhan literasi bermotivasi ekstrinsik. Perpustakaan belum bisa menumbuhkan praktik literasi berdasarkan motivasi intrinsik. Hal tersebut tampak dari tingkat kunjungan 
dan peminjaman koleksi perpustakaan yang meningkat di saat masa-masa banyak tugas perkuiahan mahasiswa.

Kampus juga belum mengintegrasikan literasi informasi dalam kurikulum perguruan tinggi mereka. Belum ada mata kuliah tentang literasi informasi. Hal tersebut penting sebab salah satu fungsi utama perpustakaan perguruan tinggi adalah mengembangkanketerampilan literasi informasi Pembelajaran literasi informasi dapat membuka kesadaran mahasiswa tentang pentingnya perpustakaan yang tidak hanya sekadar sebagai sarana pemenuhan tugas (motivasi ekstrinsik), tetapi sarana pemenuhan informasi dan pengetahuan sepanjang hayat. Pembelajaran literasi informasi juga dapat memberikan pemahaman kepada mahasiswa tentang penerimaan, evaluasi, kritik dan penggunaan dan penyebarluasan informasi yang penting bagi kehidupan mereka.

Hal yang juga luput dari perhatian kampus dan perpustakaan dalam konteks infrastruktur literasi mahasiswa adalah akses ilmu pengetahuan melalui media online. Maksud akses ilmu pengetahuan melalui media online adalah bukan hanya menyediakan sumber-sumber informasi dan pengetahuan dalam artikel di berbagai jurnal ilmiah di dunia, tetapi menyajikan konten-konten ilmu pengetahuan melalui media online dalam beragam modal literasi (teks, gambar dan suara) yang sesuai dengan kecenderungan mahasiswa milenial. Kehadiran media online mengubah otoritas dan metode transfer ilmu pengetahuan lembaga penelitian dan kampus melalui berbagai saluran pengetahuan. Jika kampus dan perpustakaannya tidak mengubah metode produksi dan distribusi ilmu pengetahuan yang sesuai dengan tuntutan zaman generasi milenial, maka otoritasnya akan tersaingi bahkan tertinggal dengan media-media online yang 
memproduksi dan mendistribusikan ilmu pengetahuan sesuai gaya milenial.

\section{Praktik Literasi}

Mahasiswa yang menjadi partisipan penelitian memiliki sikap positif terhadap literasi membaca. Para partisiapan (98 \%) menjawab bahwa membaca itu penting. Mereka juga setuju jika membaca dapat membantu untuk menemukan sesuatu yang ingin mereka ketahui. Kebanyakan mereka juga (90\%) berpandangan bahwa membaca adalah keahlian yang harus dimiliki dalam hidup. Bahkan mereka (98\%) menyatakan senang ketika membaca. Mereka kebanyakan (80\%) tidak setuju bahwa membaca itu susah dan membosanknan. Jawaban-jawaban ini sebetulnya menegaskan bahwa mereka memiliki sikap yang positif terhadap literasi membaca.

Begitu juga dengan sikap terhadap literasi menulis, separuh jumlah partisipan dari seluruh kampus yang diteliti mengatakan bahwa mereka senang menulis. Namun ketika ditanya apakah menulis itu susah, mereka terbagi dua secara merata, sebagian mengatakan bahwa menulis itu susah, sebagian lagi mengatakan bahwa menulis tidak susah. Mereka sadar bahwa menulis dapat menjadi media ekspresi ide-ide mereka. Namun, justru yang banyak menjadi halangan mereka ketika menulis adalah menemukan ide, lalu menuliskan dalam kalimat dan terakhir susahnya mencari referensi. Data ini juga menunjukkan bahwa mereka cenderung memiliki sikap yang positif terhadap literasi menulis.

Namun demikian, kenyataannya sikap tidak selalu berhubungan dengan perilaku. Perilaku literasi mahasiswa dapat dikategorikan menjadi dua. Pertama, perilaku literasi 
yang terkait dengan perkuliahan. Kedua, perilaku literasi yang tidak secara langsung terkait dengan perkuliahan tetapi diperlukan dan disenangi oleh mahasiswa.

Jika dilihat dari perspektif perilaku literasi yang pertama, dapat dikatakan bahwa mahasiswa sesunggunya telah melakukan praktik literasi, sebab sehari-sehari mereka harus berhadapan dengan teks-teks pelajaran atau perkuliahan yang diberikan oleh sang dosen. Terkait dengan hal ini, penting mengidentifikasi "membaca untuk belajar" dan membaca untuk kesenangan. Mahasiswa sudah menunjukkan perilaku membaca untuk belajar. Hal ini terlihat dari aktivitas perkuliahan yang banyak melibatkan teks. Perkuliahan mereka mengharuskan membaca sumber referensi tentang suatu topik perkuliahan, menulis makalah tentang suatu topik yang ditentukan oleh dosen, menulis tinjauan buku atau bagian dari buku, membuat peta konsep tertentu hingga mempresentasikan hasil bacaan dan karya tulis yang telah mereka buat dalam suatu kelompok diskusi kelas di hadapan teman-temannya dan dosen.

Namun demikian, membaca atau literasi karena untuk belajar atau tugas mengimplikasikan suatu motivasi ekstrinsik yang mendorong mahasiswa untuk membaca. Literasi ini terjadi pada "arena resmi" pembelajaran. Literasi pada arena resmi perkuliahan tidak menjadi kegiatan yang rekreatif, namun kegiatan yang mekanistik dan menjemukan. Karena itu, meskipun kegiatan membaca selalu digalakan mulai dari tingkat sekolah hingga kuliah, namun tetap saja tidak menumbuhkan gairah membaca. Hal tersebut karena teks yang dibaca bukan merupakan bacaan yang dibaca dengan penuh minat. Buku teks perkuliahan belum dapat menumbuhkan minat baca. Kampus dan sekolah bukan tempat buku-buku 
atau bacaan yang menyenanngkan. Pernyataan mahasiswa partisipan (38\% orang dari 1007 partisipan yang ditanyakan) menyatakan bahwa, hal yang paling menghambat mereka untuk membaca adalah bacaan yang membosankan dan tidak menemukan bacaan yang menyenangkan. Selain itu, mereka juga menyatakan (sebanyak 88\% dari 1007 partisipan) bahwa mereka akan lebih banyak membaca jika menemukan bacaan yang mudah dibaca, tidak membuat pusing dan bingung. Hal tersebut sesungguhnya sesuai dengan karakter generasi milenial. Mereka lebih suka membaca hal-hal yang mudah dipahami.

Adapun jika dilihat dari perspektif literasi di arena yang kedua (arena "tidak resmi"), maka muncul apa yang disebut dengan "membaca untuk kesenangan." Membaca untuk kesenangan adalah membaca yang tidak hanya dimaknai sebagai kegiatan reseptif mencerna pengetahuan semata. Membaca untuk kesenangan adalah pengalaman membaca seperti kegiatan bermain (tidak resmi) karena terdapat efek relaksasi dan kenikmatan yang ditimbulkan. Terkait dengan membaca untuk kesenangan ini, diketahui, kebanyakan mahasiswa partisipan (22\% orang dari 1007 yang diwawancara) membaca satu buku dalam sebulan, dan sebanyak $15 \%$ orang membaca dua buku dalam sebulan. Selebihnya mereka ada yang hanya membaca tidak tuntas, bahkan tidak membaca sama sekali karena tidak ada bacaan yang mereka senangi. Membaca untuk kesenangan tidak dapat tumbuh karena keterbatasan akses bahan bacaan yang mereka senangi.

Kebanyakan partisipan (61\% dari 1007 partisipan) menyenangi bacaan fiksi. Mahasiswa tertarik dengan genre fiksi bukan hanya pada aspek cerita atau tema cerita yang 
disampaikan dengan kadar fiktif belaka. Mereka tertarik pada sesuatu yang melampaui aspek cerita itu sendiri. Sesuatu itu adalah hal yang memberikan makna bagi mereka. Jika sebuah cerita bisa mengubah atau menggugah sesuatu dalam diri mereka, mereka akan cenderung untuk mengikuti cerita tersebut.

Partisipan juga mempraktikan literasi menulis, terutama menulis untuk tujuan perkuliahan. Dalam tugas-tugas seharihari mereka dituntut untuk menulis, baik menulis makalah, review buku atau artikel, maupun peta konsep. Banyak partisipan (63\% partisipan) mengaku bahwa mereka akan menulis dengan lebih baik jika dosen memberikan tugas makalah. Artinya motivasi menulis mereka lebih merupakan motivasi ekstrinsik, yakni menulis sekadar memenuhi tugas perkuliahan.

Oleh karena menulis lebih karena motivasi ekstrinsik, maka perilaku plagiat sebagai "cara cepat" menyelesaikan tugas menjadi marak di kalangan mahasiswa. Hal ini justru disadari oleh mahasiswa. Mereka meyakni bahwa itu merupakan suatu kesalahan, tetapi terpaksa mereka lakukan. Kesalahan mereka adalah ketidaktahuan cara mengutip yang dapat diterima dalam komunitas ilmiah.

Perilaku plagiat mencerminkan perilaku tidak literatnya mahasiswa. Selain karena disebabkan karena motivasi ekstrinsik dalam menulis, juga ada sebab lain yang perlu diperhatikan, yakni kondisi atau konteks kehidupan generasi milenial. Salah satu problem generasi milenial adalah ketakutan akan kegagalan dan demotivasi secara akademik serta tantangan karir. Karena itu, mereka berupaya untuk sukses dalam pendidikan dan karir, termasuk pemenuhan tugas-tugas perkuliahan. Untuk menghindari dan mengikis 
budaya plagiat, mahasiswa membutuhkan motivasi untuk menghadapi berbagai tugas kehidupan, termasuk tugas-tugas perkuliahan yang dikerjakan secara bertanggung jawab.

Namun tidak semua mahasiswa tidak literat dan melakukan plagiat. Ada sekelompok mahasiswa yang mempraktikan literasi di kampus. Kelompok mahasiswa tersebut adalah kelompok yang aktif menulis. Kelompok penulis penting dikemukakan karena posisi mereka sebagai penggerak literasi kepada teman-teman sebayanya sesama mahasiswa. Hal ini terkait juga dengan budaya peer group di kalangan generasi milenial, yakni mereka selalu mengacu dan terikat pada aktivitas-aktivitas yang dilakukan kelompok sebayanya.

Ketiga kelompok tersebut adalah; (1) komunitas pers mahasiswa; (2) komunitas diskusi dan kepenulisan; dan (3) mahasiswa-mahasiswa yang secara mandiri mengembangkan minat dan dunia kepenulisan. Tiga kelompok inilah yang mengembangkan praktik literasi berdasarkan motivasi intrinsik. Namun, perlu dicatat bahwa klasifikasi ketiga kelompok tersebut bukan bersifat statis, tetapi dinamis. Artinya terkadang sekelompok mahasiswa berada di komunitas yang pertama dan kedua secara bersamaan.

\section{Saran}

Berdasarkan pembahasan dan simpulan yang telah dikemukakan. Beberapa saran yang dapat diajukan adalah sebagai berikut.

1. Kampus perlu mengembangkan infrastrukur literasi melalui wadah cyber literacy dengan perpustakaan universitas sebagai leading sector. Hal ini perlu dilakukan 
karena berdasarkan temuan penelitian dan konteks zaman yang berkembang, akses informasi dan produk ilmu pengetahuan harus adaptif dengan perkembangan teknologi informasi. Hal tersebut perlu juga ditopang dengan kebijakan di tingkat Kementerian Agama (khususnya Direktorat Pendidikan Tinggi Agama Islam) dan Kementerian Riset, Teknologi dan Perguruan Tinggi untuk memajukan layanan literasi sebagai keharusan keterampilan di abad ke-21.

2. Perlu memasukan literasi informasi sebagai salah satu mata kuliah wajib dalam Perguruan Tinggi Keagamaan Islam Negeri (PTKIN) dalam hal ini Universitas Islam Negeri(UIN). Pembelajaran mata kuliah literasi informasi ini juga sebagai bentuk upaya membangun ketahanan mahasiswa dalam penyelesaian persoalan-persoalan yang dihadapi melalui kesadaran dan keterampilan literasi yang dimiliki. Pembelajaran mata kuliah literasi informasi juga perlu untuk menopang kesadaran dan memantik motivasi instrinsik literasi mahasiswa.

3. Perlu diversifikasi metode produksi dan distribusi ilmu pengetahuan yang selaras dengan konteks generasi milenial, yakni cepat, mudah, bergaya (stylist) dan tidak membosankan. Misalnya mengadopsi metode narasi fiksi dalam penyampaian ilmu pengetahuan yang dibutuhkan. Hal ini perlu didorong oleh Direktorat Pendidikan Tinggi Islam, agar perguruan tinggi tetap menjadi otoritas ilmu pengetahuan bagi generasi milenial di tengah era disrupsi dan revolusi teknologi informasi. Diversifikasi itu juga bisa dilakukan dalam proses pembelajaran atau perkuliahan, seperti mengintegrasikan literasi informasi, digital, perkembangan teknologi informasi dan gaya 
milenial dalam proses pembelajaran. Contohnya pembuatan tugas dalam beragam corak media digital yang dapat memantik aktualisasi mahasiswa.

4. Perlu penguatan komunitas-komunitas literasi yang ada di sekitar kampus. Hal ini karena pentingnya peran komunitas dalam pengembangan literasi di kalangan anak muda. Langkah ini bisa berawal dari komunitaskomunitas yang telah ada, seperti lembaga pers mahasiswa, komunitas diskusi intra kampus dan bisa berlanjut pada Himpunan Mahasiswa Jurusan (HMJ) sebagai penggerak literasi di lingkungan kampus. Program tidak harus dijalankan dengan menumbuhkan sebuah komunitas baru, tetapi memperkuat komunitas-komunitas ada sebagai basis penggerak kesadaran literasi mahasiswa. Penguatan tersebut dapat berupa program pembinaan komunitas literasi kampus, atau pengembangan literasi mahasiswa melalui mentor sebaya, yakni para aktivis komunitas literasi menjadi mentor pengembangan literasi antar sesama temannya. Kebijakan seperti ini harus dimulai dari regulasi yang mengatur hal tersebut, dan ini perlu dikeluarkan oleh lembaga yang berwenang, dalam hal ini Kementerian Agama melalui Direktorat Perguruan Tinggi Agama Islam dan Direktorat Jenderal Pembelajaran dan Kemahasiswaan Kementerian Riset, Teknologi dan Pendidikan Tinggi. 


\section{Daftar Pustaka}

Abdullah, Amin. 2007. Desain Pengembangan Akademik IAIN Menuju UIN Sunan Kalijaga: Dari Pendekatan Diktomistik-Atomistik ke Arah Integratif-Interkonektif. Dalam Fahruddin Faiz (ed.). Islamic Studies dalam Paradigma Interkoneksi (Sebuah Antologi). Yogyakarta: Suka Press.

Abidin, Yunus, Tita Mulyati, Hana Yunansah. 2017. Pembelajaran Literasi: Strategi Meningkatkan Kemampuan Literasi Matematika, Sains, Membaca dan Menulis. Jakarta: Bumi Aksara.

Afflerbach, Peter, Byeoung-Young Cho. 2009. Identifying and Describing Constructively Responsive Comprehension Strategies in New and Traditional Forms of Reading. Dalam Israel, Susan E., Gerald D. Duffy (ed). Handbook of Research on Reading Comprehension. New York dan London: Routledge. h. 69-90.

Akmaliah, Wahyudi. 2018. Media Daring dan Matinya Otoritas Pengetahuan? Dalam Setowara, Subhan (ed.). Muslim Milenal: Catatan dan Kisah Wow Muslim Zaman Now. Bandung: PT. Mizan Pustaka. h. 48-53. 
Alam, Umar Falahul. 2013. Kemampuan Literasi Informasi Mahasiswa dan Peranan Perpustakaan dalam Proses Belajar Mengajar di Perguruan Tinggi. Pustakaloka, Volume 5, Nomor 1.

Alexander, Patricia A, Tamara L. Jetton. 2000. Learning from Text: A Multidimensional and Developmental Perspective. Dalam Kamil, Michael L., dkk. Handbook of Reading Research. New Jersey: Lawrence Erlbaum Associates. h. 285-309

Alhumami, Amich. Literasi dan Pembangunan Ekonomi. Kompas, 19 Januari 2018.

Ali, Hasanuddin, Lilik Purwandi. 2017. Millenial Nusantara:

Pahami Karakternya, Rebut Simpatinya. Jakarta: PT Gramedia Pustaka Utama.

Antoro, Billy. 2017. Gerakan Literasi Sekolah: Dari Pucuk Hingga Akar, Sebuah Refleksi. Jakarta: Direktorat Jenderal Pendidikan Dasar dan Menengah Kementerian Pendidikan dan Kebudayaan RI.

Barton, David, Mary Hamilton, Roz Ivanic. 2000. Introduction: Exploring Situated Literacies. Dalam Barton, David, Mary Hamilton, Roz Ivanic (ed). Situated Literacies: Reading and Writing in Context. London dan New York: Routledge.

Barton, David, Mary Hamilton. 2000. Literacy Practices. Dalam Barton, David, Mary Hamilton, Roz Ivanic (ed). Situated Literacies: Reading and Writing in Context. London dan New York: Routledge. h. 7-14.

Black, Christine, Sarah Crest, dan Marr Volland. 2001. Building A Successful Information Literacy 
Infrastructure on the Foundation of Librarian-Faculty Collaboration. Research Strategies, Volume 18, Issue 3: 215-225.

Blum, Susan D. 2009. My Word!: Plagiarism and College Culture. Ithaca dan London: Cornell University Press.

Brandt, Deborah. 2001. Literacy in American Lives. Cambridge: Cambridge University Press.

Brandt, Deborah, Katie Clinton. 2002. Limits of the Local: Expanding Perspectives on Literacy as Social Practice. Journal of Literacy Research Vol. 34, Nomor. 3: $337-$ 356.

Buletin El-Manhaj, Edisi XXV, 2017. Persma Walisongo Era Milenial. Semarang: Buletin El-Manhaj.

Clark, Christina, Amelia Foster. 2005. Children's and Young People's Reading Habits and Preferences: The who, what, why, where and when. London: National Literacy Trust.

Clark, Christina, Kate Rumbold. 2006. Reading for Pleasure. London: National Literacy Trust.

Cohen, David K., dan Monica P. Bhatt. 2012. The Importance of Infrastructure Development to High-Quality Literacy Instruction. Future of Children, Volume 22, Nomor 2.

Connachie, Stephanie M. 2010. Disciplinary Literacy: A Principle-Based Framework. Dalam Stephanie M Stephanie M dan Anthony R. Petrosky (eds.). Contents Matters: A Disciplinary Literacy Approach to Improving Student Learning. San Fransisco: Jossey-Bass A Willey Imprint. 
Creswell, John W. 2007. Qualitative Inquiry \& Research Design: Choosing among Five Approaches. London dan New Delhi: Sage Publications.

Dewayani, Sophie. 2011. "Stories of the Intersection: Indonesian "Street Children" Negotiating Narratives at the Intersection of Society, Childhood, and Work." Disertasi Doktoral di University of Illinois at UrbanaChampaign.

Dewayani, Sofie. 2017. Menghidupkan Literasi di Ruang Kelas. Yogyakarta: Kanisus.

Dewayani, Sofie, Pratiwi Retnaningdyah. 2017. Suara dari Marjin: Literasi sebagai Praktik Sosial. Bandung: PT. Remaja Rosda Karya.

Drake, Susan M, Rebecca C. Burn. 2004. Meeting Standards through Integrated Curriculum. Alexandria, USA: Association for Supervision and Curriculum Development.

Dyson, Anne Haas. 1997. Writing Superheroes: Contemporary Childhood, Popular Culture, and Class-room Literacy. New York dan London: Teachers Collage, Columbia University.

Faisal, Muhammad. 2017. Generasi Phi $\pi$ : Memahami Milenial Pengubah Indonesia. Jakarta: Republika.

Faiz, Fahruddin. 2007. Mengawal Perjalanan Sebuah Paradigma (Sebuah Pengantar). Dalam Fahruddin Faiz (ed.). Islamic Studies dalam Paradigma Interkoneksi (Sebuah Antologi). Yogyakarta: Suka Press.

Fransman, Jude. 2005. Understanding Literacy: A Concept Paper. Dalam Paper commissioned for the EFA Global 
Monitoring Report 2006, Literacy for Life, UNESCO.

Gee, James Paul. 2000. The New Literacy Studies: from 'Socially Situated' to the Work of the Social. Dalam Barton, David, Mary Hamilton, Roz Ivanic (ed). Situated Literacies: Reading and Writing in Context. London dan New York: Routledge.

Gustini, Neng, Dede Rohaniawati, Anugrah Imani. 2016. Budaya Literasi (Model Pengembangan Budaya Baca Tulis Berbasis Kecerdasan Majemuk Melalui Tutor Sebaya). Yogyakarta: Deepublish Publisher.

Guthrie, John T., Alan Wigfield. 2000. Engagement and Motivation in Reading. Dalam Kamil, Michael L., dkk. Handbook of Reading Research. New Jersey: Lawrence Erlbaum Associates. h. 403-423.

Hamalik, Oemar. 2004. Psikologi Belajar dan Mengajar. Bandung: Sinar Baru Algensindo.

Harliansyah, Faizuddin. 2016. Pengembangan Kurikulum Information Literacy di Perguruan Tinggi. Makalah dipresentasikan pada acara "Peningkatan Kompetensi Laboran dan Pustakawan PTKI," di Bogor 20-22 April 2016.

Haycock, Ken. 1995. "Research in Teacher-Librarianship and The Institutionalization of Change." Dalam Selected Papers from The Annual Conference of the International Association of School Libarianship, 23 ${ }^{\text {rd }}$, Pittsburgh, Pennyslavania, July 17-22 1994.

Hull, Gynda, dkk. 2003. Multiple Literacies. A Compilation for Adult Educators. Colombus: ERIC Clearinghouse on Adult, Career, and Vocational Education. 
Institut Agama Islam Negeri Walisongo. 2013. Blue Print Pengembangan Akademik IAIN/UIN Walisongo untuk 25 Tahun (2013-2038). Semarang: IAIN Walisongo Semarang.

Irawan, Yuliana. Tanpa tahun. Filosofi Keilmuan UIN Antasari. Makalah, tidak diterbitkan.

Ivanic, Roz. 2009. Bringing Literacy Studies into Research on Learning Across the Curriculum. Dalam Mike Baynham dan Mastin Prinsloo (eds.). The Future of Literacy Studies. Hampshire dan New York: Palgrave Macmillan.

Kasali, Rhenald. 2018. The Great Shifting. Jakarta: PT. Gramedia Pustaka Utama.

Laksono, K, P. Retnaningdyah. 2018. Literacy Infrastructure, Acces to Book, and the Implementation of the School Literacy Movement in Primary School in Indonesia. IOP Confrence Series: Materials Science and Enginering, The Consortium of Asia-Pacific Education Universities.

Lankshear, Colin, Michele Knobel. 2011. New Literacies. New York: Open University Press.

Leu, Donald J., Charles K. Kinzer, Julie Coiro, Jill Castek, dan Laurie A Henry. 2013. New Literacies: A Dual-Level Theory of the Changing Nature of Literacy, Instruction and Assessment. Dalam Alvermann, Donna E., Norman J. Unrau, Robert B. Ruddell (ed). Theoritical Models and Process of Reading. Newark DE: International Reading Association. h. 1150-1180. 
Lukens-Bull, Ronald A. 2013. Islamic Higher Education in Indonesia: Continuity and Conflict. New York: Palgrave MacMillan.

Mannheim, Karl. 1972. The Problems of Generations. Dalam Paul Kecskemeti (ed). Karl Manheim: Essays. New York dan London: Routledge.

Martyn, Edwards. 2012. Literacy Practies: Using the Literacies for Learning in Further Education Framework to Analyse Literacy Practies on a Post-Compulsory Education and Training Teacher Education Programme. Student Engagement and Experience Journal, Volume 1, Nomor, 1: 1-10.

Meho, Lokman I. 2006. E-Mail Interviewing in Qualitative Research: A Methodological Discussion. Journal of the American Society for Information Science and Technology, Volume 57, Nomor 10: 1284-1295.

Miller, John. W, Michael C. McKenna. 2016. World Literacy: How Countries Rank and Why It Matters. New York dan London: Routledge.

Mullis, Ina V.S., Michael O Martin, Ann. M. Kennedy, Kathleen L Trong, dan Marian Sainsbury. 2009. PIRLS 2011 Assesment Framework. Amsterdam: The International Association for the Evaluation of Educational Achievement (IEA).

Naibaho, Kalarensi. 2007. Menciptakan Generasi Literat melalui Perpustakaan. Makalah Lomba, tidak diterbitkan.

Organisation for Economic Cooporation and Development (OECD). 1999. Measuring Students Knowledge and 
Skills: A New Framework for Assesment. Paris: OECD Publication Services.

Pahdepie, Fahd. 2018. Yang Mengubah, Yang Menggugah.

Dalam Setowara, Subhan (ed.). Muslim Milenal:

Catatan dan Kisah Wow Muslim Zaman Now. Bandung:

PT. Mizan Pustaka. h. 201-210.

Pedoman Akademik IAIN Antasari Banjarmasin. 2015. Pedoman Akademik IAIN Antasari Banjarmasin. Banjarmasin: IAIN Antasari.

Panduan Program Sarjana (S.1 dan Diploma (D.3), tahun akademik 2017/2018. 2017. Panduan Program Sarjana (S.1 dan Diploma (D.3), tahun akademik 2017/2018. Semarang: UIN Walisongo Semarang.

Perpustakaan UINSA. 2016. Laporan Pertanggungjawaban (LPJ): Bedah Buku Islam Nusantara dan Islam Berkemajuan. Surabaya: Perpustakaan UIN Sunan Ampel Surabaya.

PedomanAkademik UIN Mataram. 2017. Pedoman Akademik UIN Mataram. Mataram: UIN Mataram.

Pedoman Pendidikan UIN Maulana Malik Ibrahim Malang. 2017. Pedoman Pendidikan UIN Maulana Malik Ibrahim Malang. Malang: UIN Maulana Malik Ibrahim.

Prothero, Stephen. 2008. Religious Literacy: What Every American Needs to Know-and Doesn't. New York: Harper Collins Publishers.

Putra, Resear Arias. 2017. Kegiatan Diskusi Komunitas Asiyah di Pergerakan Mahasiswa Islam Indonesia (PMII) Rayon Humaniora Park. Skripsi pada Program 
Studi Sosiologi, Fakultas Ilmu Sosial dna Humaniora UIN Sunan Kalijaga Yogyakarta.

Rackley, Eric D. 2010. "Motivation for Religious Literacy Practices of Religious Youth: Eximining the Practices of Letter day Saint and Methodist Youth in One Community." Disertasi Doktoral di Universitas Michigan.

Redlich-Amirav, Dorit, Gene Hagginbottom. 2014. New Emerging Technologies in Qualitative Research. The Qualitative Report, Volume 19 Nomor 26: 1-14.

Rukmana, Aan. 2018. Mengajarkan Kedalaman untuk Generasi Milenial, Dalam Dalam Setowara, Subhan (ed.). Muslim Milenal: Catatan dan Kisah Wow Muslim Zaman Now. Bandung: PT. Mizan Pustaka. h. 196-201.

Sahlan, Asmaun. 2012. Religiusitas Perguruan Tinggi: Potret Pengembangan Tradisi Keagamaan di Perguruan Tinggi Islam. Malang: UIN-Maliki Press.

Sari, Esti Swatika, Setyawan Pujiono. 2017. Budaya Literasi di Kalangan Mahasiswa FBS UNY. Litera Vol. 16, Nomor 1.

Schmitt, Edward. 2009. Four Case Studies: The Reading Attitudes and Practices of Teachers and Students in Second Grade. Tesis Master di Graduated Collage of Bowling Green State University.

Seitz, Lindsey. 2010. Student Attitudes Towards Reading: A Case Study. Journal of Inquiry and Action in Education, Volume 3, Nomor 2: 30-44.

Setowara, Subhan. 2018. Tentang Muslim Milenial dan 
Kiprah Mereka. Dalam Subhan Setowara (ed.). Muslim Milenial: Catatan dan Kisah Wow Muslim Zaman Now. Bandung: PT. Mizan Pustaka.

Siregar, Parluhutan. 2014. Integrasi Ilmu-ilmu Keislaman dalam Perspektif M. Amin Abdullah. Miqot, Volume XXXVIII, Nomor 2.

Souza, Lynn Mario T Menezes De. 2015. Indigenous Literacies in Literacy Studies. Dalam Jennifer Rowsel dan Kate Pahl (eds.). The Routledge Handbook of Literacy Studies. London dan New York: Routledge Taylor and Francis Group.

Strauss, William, Neil Howe. 1991. Generations: The History of American Future, 1584-2069. New York: William Morrow and Company Inc.

. 1997. The Fourth Turning: An American Prophecy. New York: Broadway Book.

Street, Brian V. 2001. Introduction: Ethographic Perspectives on Literacy. Dalam Brian, Street V. Literacy and Development: Ethographic Perspectives. London dan New York: Routledge.

. 2003. What's New in New Literacy Studies? Critical Approach to Literacy in Theory and Practies. Current Issues in Comparative Education Vol. 5, Nomor 2.

. 2005. Understanding and Defining Literacy. Dalam Paper commissioned for the EFA Global Monitoring Report 2006, Literacy for Life, UNESCO.

Syukur, Yanuardi. 2018. Generasi Milenial dan Budaya Menulis. Dalam Dalam Subhan Setowara (ed.). Muslim 
Milenial: Catatan dan Kisah Wow Muslim Zaman Now. Bandung: PT. Mizan Pustaka.

Tarigan, Henry Guntur. 2008. Membaca sebagai Suatu Keterampilan Berbahasa. Edisi Revisi. Bandung: Penerbit Angkasa.

.2013. Menulis sebagai Suatu Keterampilan Berbahasa. Edisi Revisi. Bandung: Penerbit Angkasa.

Taufik, M. 2013. Merajut Paradigma Keilmuan Berbasis Internalisasi-Integrasi dan Interkoneksi. Dalam H.M. Taufik (ed.). Horizon Ilmu: Merajut Paradigma Keilmuan Berbasis Internalisasi-IntegrasiInterkoneksi. Mataram: Lembaga PengakajianPublikasi Islam dan Masyarakat IAIN Mataram.

Taylor, Shelley E., Letitia Anne Peplau, David O. Sears. 2009. Psikologi Sosial. Edisi Kedua Belas. Jakarta: Kencana.

Thompson, S., dkk. 2012. Highlights from PIRLS 2011: Reading Achievment of U.S Fourth-Grade Students in an International Context (NCES2013-010). Washington D.C: National Center for Education Statistic, Institute of Education Science.

UNESCO. 2005. Education for Life: Literacy for All. Paris: UNESCO.

UNESCO Institute for Life Long Learning. 2017. Fostering a Culture of Reading and Writing. Hamburg: UNESCO Institute for Life Long Learning.

UIN Sunan Ampel Surabaya. 2017. Pedoman Akademik Tahun 2017. Surabaya: UIN Sunan Ampel Surabaya.

UPT Perpustakaan UIN Walisongo. 2017. Buku Panduan 
Perpustakaan. Semarang: UPT Perpustakaan UIN Walisongo.

World Economic Forum. 2016. New Vision for Education: Fostering Social and Emotional Learning through Technology. Cologny, Geneva: World Economic Forum.

World Economic Forum. 2015. New Vision for Education: Unlocking the Potensial of Technology. Cologny, Geneva: World Economic Forum.

Yin, Robert K. 1997. Studi Kasus (Desain dan Metode). Jakarta: Rajawali Press.

\section{Undang-Undang dan Peraturan}

AD/ART LPM Ro'yuna 2012/2011

Peraturan Menteri Pendidikan dan Kebudayaan Nomor 73 Tahun 2013

Peraturan Menteri Pendidikan dan Kebudayaan Nomor 73 Tahun 2013 tentang Penerapan Kerangka Kualifikasi Nasional Indonesia Bidang Pendidikan Tinggi.

Peraturan Presiden Nomor 8 Tahun 2012 tentang Kerangka Kualifikasi Nasional Indonesia.

Undang-Undang Nomor 12 Tahun 2012 tentang Pendidikan Tinggi.

\section{Internet}

http://antasari-cendekia.blogspot.com/ Diakses tanggal 20 Juli 2018.

http://uapminovasi.com/sample-page-2/ Diakses tanggal 15 
Juli 2018.

http://www.library.uinsby.ac.id. Diakses tanggal 20 Juli 2018.

http://www.mediasolidaritas.com/turn-back-hoaxmenangkal-hoax-dan-gerakan-literasi-media/ Diakses tanggal 20 Juli 2018.

http://www.solidaritas-uinsa.org/lpm-solidaritas-uinsa/ Diakses tanggal 5 Juli 2018.

http://www.uin-antasari.ac,id/sejarah/\# Diakses tanggal 20 Juli 2018.

https://lpmarena.com/2018/04/25/agama-dan-munculnyakelas-sosial-baru/ Diakses tanggal 20 Juli 2018.

https://pmarena.com/2018/07/10/risiko-eksploitasilingkungan-dalam-pariwisata/ Diakses tanggal 20 Juli 2018.

https://lpmarena.com/2018/07/17/menimbang-keadilanpengadaan-tanah-pembangunan-untuk-kepentinganumum/ Diakses tanggal 20 Juli 2018.

https://lpmarena.com/tentang-kami/. Diakses tanggal 1 Juli 2018.

https://skmamanat.com/bhineka-tunggal-ika-dalam-bayangbayang-pilkada/ Diakses tanggal 20 Juli 2018.

https://skmamanat.com/ini-16-ukm-tingkat-universitas-diuin-walisongo/ Diakses tanggal 20 Juli 2018.

https://skmamanat.com/tentang-kami/\# Diakses tanggal 5 Juli 2018.

https://theconversation.com/semangat-membaca-di-pelosok- 
menantang-anggapan-minat-baca-rendah-82023 Diakses tanggal 19 Juli 2018.

https://webcapp.ccsu.edu/?news=1767\&data.

Diakses tanggal 20 Januari 2018.

https://www.kemdikbud.go.id/main/blog/2016/12/peringkatdan-capaian-pisa-indonesia-mengalami-peningkatan. Diakses tanggal 20 Januari 2018.

https://www.qureta.com/post/toleransi-atas-nama-cinta-2 Diakses tanggal 20 Juli 2018.

Lancaster University dan University of Stirling. 2007. The Literacies for Learning in Further Education (LfLFE). Didapat dari http://www.lancaster.ac.uk/lfffe/ description/introduction.htm. Diakses tanggal 4 Mei 2018.

\section{Informan}

A, Dosen Jurusan Pendidikan IPS Fakultas Tarbiyah dan Keguruan UIN Mataram

Aini, Mahasiswi Fakultas Tarbiyah dan Keguruan UIN Mataram

Ali Mufrodi, Wakil Rektor III UINSA

Evi F, Dosen dan Kepala Lab Fak. Tarbiyah UINSA

Fatoni Hasyim, Ketua LP2M UINSA

H, Dosen Studi Agama-Agama Fakultas Tarbiyah dan Keguruan UIN Mataram

Indah, Mahasiswi Fakultas Dakwah dan Komuniasi UIN Mataram 
Kabag Kemahasiswaan UIN Walisongo Semarang

Kabag Kurikulum UIN Walisongo Semarang

Kepala Lembaga Penjamin Mutu UIN Walisongo Semarang

Kepala Perpustakaan UIN Malang

Kepala Perpustakaan UIN Mataram

Kepala UPT Perpustakaan UIN Walisongo Semarang

Ketua DEMA UIN Walisongo

M. Thohir, Bagian Pengembangan Mahasiswa LPM UINSA

Mahasiswa Fakultas Syariah dan Hukum UIN Mataram

Mahasiswi Fakultas Dakwah dan Komunikasi UIN Mataram

Nurma, Mahasiswi Fakultas Tarbiyah dan/Keguruan UIN Mataram

Pembantu Dekan I Fakultas Tarbiyah dan Keguruan UIN Malang

Pembantu Rektor III UIN Antasari Banjarmasin

Riski Ramdhani, Anggota Pers Solidaritas UINSA

Rofik, Kabag Administrasi UINSA

S, Ketua Jurusan PAI UIN Mataram

Siti Aminah, Mahasiswi UIN Sunan Kalijaga Yogyakarta

T, Mantan Aktivis Pers Mahasiswa UIN Walisongo Semarang

Umi Rodliyah, Kabag Verifikasi Perpustakaan UINSA

Wakil Rektor Bidang Kemahasiswaan UIN Mataram

Wiji Agustin Sasmita, Ketua Pers Solidaritas UINSA 
Yenita, Mahasiswa Mahasiswi Fakultas Tarbiyah dan Keguruan UIN Mataram.

Zaidan, Mahasiswa Fakultas Dakwah dan Komunikasi UIN Mataram

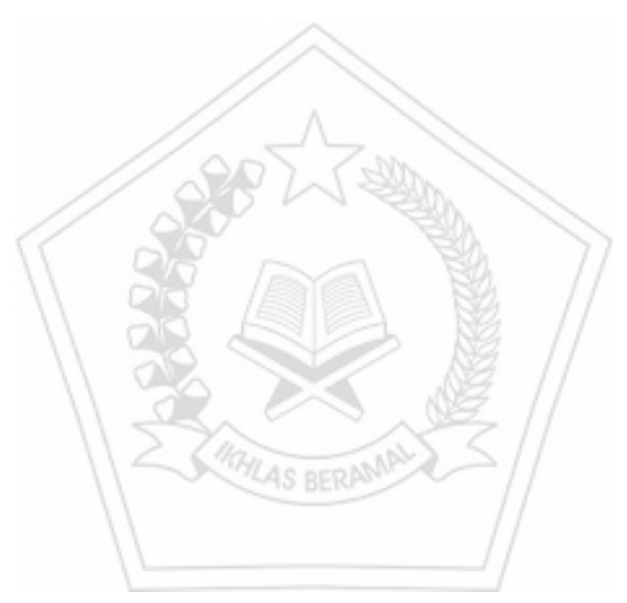




\section{Biodata Penulis}

Agus Iswanto adalah peneliti ahli madya pada Balai Litbang Agama Semarang, lahir di Jakarta, 23 Agustus 1983. Riwayat pendidikan: S1 di Jurusan Bahasa dan Sastra Arab, Fakultas Adab UIN Sunan Kalijaga Yogyakarta; S2 di Sekolah Pascasarjana UIN Syarif Hidayatullah Jakarta dengan konsentrasi pada kajian Islam dan filologi. Bidang penelitiannya adalah khazanah keagamaan, dengan fokus pada naskah-naskah keagamaan (pegon). Selain itu, sekarang juga fokus pada kajian tentang praktik literasi keagamaan. Beberapa karya tulis mutakhir baik ilmiah maupun populer sebagai berikut: "Praktik Literasi Agama pada Masyarakat Indonesia Tempo Dulu: Tinjauan Awal atas Naskah-naskah Cirebon" di Jurnal Manuskripta Vol. 8 No. 2 (2018); "Praktik Literasi Berbasis 'Madrasah Riset': Pelaksanaan Gerakan Literasi di Mansa Yogyakarta" di Jurnal Al-Qalam, Vol. 24, No. 2 (2018); "Membaca Kecenderungan Pemikiran Islam Generasi Milenial" dalam Jurnal Harmoni Vol. 17 No. 1 (2018); "Building Harmony through Religious Reception in Culture: Lesson Learned from Radin Jambat Folktale of Lampung" di Analisa Journal of Social Science and Religion Vol. 2, No. 2 (2017); "Tradisi Islam, Tradisi Arab dan Tradisi Jawa: Membaca Karya dan Pemikiran KH. Ahmad 
ar-Rifai Kalisalak, di Jurnal Lektur Keagamaan Vol. 15, No.

2 (2017); "Minat Baca dan Pilihan Literatur Keagamaan Guru Pendidikan Agama Islam (PAI) SMA Kota Bandung" di Jurnal Edukasi: Jurnal Penelitian Agama dan Keagamaan Vol. 15, No. 2 (2017); "Ideologi dalam Literatur Keagamaan pada Aktivis Dakwah dan Kajian Islam di ITB Bandung," di Jurnal Smart Vol. 3, No. 1 (2017). Karya-karya lain dapat dilihat di googlescholar: https://scholar.google.co.id/citation $\mathrm{s} ? \mathrm{hl}=$ en\&user=MDezWOkAAAAJ. Bisa dihubungi di agus. iswanto83@gmail.com atau 08170406878.

Moch. Lukluil Maknun, lahir di Blitar, 13 November 1984. Riwayat pendidikan: S.1 UGM/Sastra Asia Barat, lulus 2006. S.2 UGM/Kajian Timur Tengah, lulus 2012. Publikasi karya ilmiah: Konsepsi Jin dalam Hikayat Tamim ad-Dari, Jurnal Widyariset 15(1), 2012. Tradisi Pernikahan Islam di Kota Pekalongan Jurnal Ibda 11(1) 2013. Kesenian Rebana di Kabupaten Pati, -penulis kedua- Artikel dalam Prosiding Seminar Hasil Kajian Seni Budaya Keagamaan di Jateng: Model Pembinaan Seni Rebana, Yogyakarta, 28-30 Juni 2013, 1(3) 2013. Buku Bahasa Arab Madrasah Ibtidaiyah (MI) di Pekalongan, Jurnal Kajian 11(1) 2014. Implementasi Tradisi Ikhtilaf dan Budaya Damai di Pesantren Nurul Ummah dan Ar-Romli Yogyakarta, Jurnal Analisa, 21(2) 2014. Esensi Dakwah Wayang Kulit Banjar Dalang Iderus (Studi Transkripsi Peentasan Tahun 2009 di Martapura) Jurnal Smart 1(2). Arabic Amiyah For Pilgrims (Study $8 \mathrm{KBIH}$ in District/ City of Pekalongan 2015) Jurnal Al-Qalam 22(1), 167-176. Indeks Keterbacaan Pengguna Buku Keagamaan Kelas XI di Madrasah Aliyah Kab. Gunungkidul, Edukasi:Jurnal Kajian Pendidikan Agama dan Keagamaan 14(3) 2016. Nomor HP: 081932033744, Email: lukluilmaknun84@gmail.com 
Mustolehudin, lahir di Kebumen, 25 Mei 1974. Riwayat Pendidikan: S1 Akidah Filsafat IAIN Walisongo, Semarang, lulus 1998. S1 Ilmu Perpustakaan, Universitas Yarsi, Jakarta, lulus 2007. S2 Etika/Tasawuf, Pascasarjana IAIN Walisongo, Semarang, lulus 2012. Publikasi karya ilmiah: Etika Jawa dalam Perspektif Islam:Kajian terhadap Serat Wirid Hidayat Jati'(Jurnal Analisa No.18. Tahun IX Oktober 2004), Dimesi Moral dalam Kidung Mantra Wedha:Kajian Filosofis terhadap Mistik dan Makrifat Sunan Kalijaga" (Jurnal Analisa No.19 Tahun X April 2005), Fungsi Teknologi Informasi (Internet) dalam Penyebaran Informasi Keagamaan"(Jurnal Analisa, Vol XII, No.01 Januari-April 2007), Pengelolaan Literatur Masjid Pada Era Globalisasi Informasi (Jurnal Analisa, Vol, XVI, No.02 Juli-Desember 2009), Elektronik dan Media Dakwah:Tinjauan terhadap Tele Tilawah di TVRI Nasional Jakarta" (Jurnal Bimbingan Konseling Islam, Vol, 1, No. 02 Juli-Desember 2009). Nilai moral dalam lirik dangdur Rhoma Irama (Jurnal Analisa Vol. 19 No.02 Juli- Desember 2012, Mengenal Ajaran Gerakan Syiah (Jurnal Harmoni No.4, Vol.11, Oktober-Desember 2012), dan Pandangan Ideologis-Teologis Muhammadiyah dan Majelis Tafsir Alquran (Studi Gerakan Purifikasi Islam di Surakarta) Jurnal Analisa Volume 21 No.01 Juni 2014. Pendekatan Sosial Budaya dalam Penyelesaian Potensi Konflik pendirian rumah ibadah: (KasusVihara dan Masjid di Banyumas)," Journal Al Qalam Vol. 21 No. 1 June 2015 Balai Litbang Agama Makassar, "Membangun harmoni melalui gulat okol di Desa Setro, Menganti, Gresik", a book chapter "Belajar kearifan lokal budaya membangun kerukunan beragama, published by Penerbit CV Bumi Intaran Yogyakarta, 2015, "Nilai-nilai perdamaian dalam teks Wacan sindujoyo Babad 
Kroman Gresik," Journal Smart Vol. 01 No.01 June 2015 Balai Litbang Agama Semarang, "Bimbingan manasik haji di kabupaten Banjar; Antara regulasi dan praktik dalam bunga bunga Pelayanan Bimbingan Manasik Haji oleh Kementerian Agama di Jawa Timur," Kalimantan Selatan, dan Nusa Tenggara Barat. Published by CV. Bumi Intaran Yogyakarta 2015, Relasi Modal Sosial Dan Kerukunan Umat Beragama: Studi Kasus Di Kecamatan Larangan, Brebes Jurnal Penamas Vol 29 No 1 April-Juni 2016, Implementasi PP. No. 48 Tahun 2014 antara Regulasi dan Praktik (Studi Kasus di Kabupaten Konawe dan Kota Semarang) Jurnal Harmoni Vol 15 No. 1 Januari - April 2016, Narasi radikalisme dalam majalah Asy Syariah (Bahan bacaan kelompok Salafi Ma'had Ittibaus Sunnah Klaten) Bunga rampai CV. Bumi Intaran Tahun 2016, Siaran keagamaan melalui radio di Kota Tegal Prosiding Tahun 2016 Balai Litbang Agama Semarang. Nomor HP: 0813-8082-4869. Email: mustolehudin@kemenag.go.id

Umi Masfiah, lahir di Banyumas, 18 Oktober 1975. Riwayat pendidikan: S1, S2 UIN Walisongo Semarang. Publikasi karya ilmiah: Respon Santri terhadap Kitab Risalat al-Mahid sebagai Pedoman Santri di Pesantren Manbail Futuh, Jenu, Tuban, Jawa Timur, Jurnal Analisa Vol XVII Juli -Desember 2010. Kajian Naskah Kitab Tahqiq di Kalimantan Selatan (Bunga Rampai. 2010. Yogyakarta: CV Arti Bumi Intaran). Agama dan Nasib Anak Jalanan. 2011. Yogyakarta: e Nusantara. Kajian Kitab Ta'limul Muta'allim di Pondok Pesantren Abu Dzarrin Bojonegoro. (Bunga Rampai. 2011. Semarang: Robar Bersama). Arsitektur dan Peran Masjid Gedhe Kauman Yogyakarta dalam Lintasan Sejarah, Jurnal Inferensi Vol. 6, No.1, Juni 2012. Falsafah Damai Untuk Borneo (Studi terhadap Pesan Damai dalam Karya 
Cendekiawan Muslim Kalbar Pasca Reformasi, Jurnal Smart Vol 1 nomor 1 2015. Nomor HP: 081575235676 E-mail: masfiah_umi@yahoo.com.

Subkhan Ridlo, lahir Banyumas, 22 Februari 1973. Riwayat pendidikan: S.1 IAIN Walisongo/Tafsir Hadits, lulus 2001. S.2 UIN Syarif Hidayatullah/Filologi, lulus 2011. Publikasi karya ilmiah: Penafsiran ayat sabar Syaikh Nawawi dalam kitab Tafsir Munir. Agama Sarkawi. Tabyin al-Islah li Murid al-Nikah bi al-Sawab Karya Ahmad Rifai Kalisalak (Suntingan teks dan Pengungkapan Isi). Eksistensi kesenian Hadrah di Kabupaten Purworejo. Studi Kitab Fathu al-Manan Karya Maftuh Bastu al-Birri. Nomor HP: 085891874967. Email: subkhanridlo@gmail.com.

R. Aris Hidayat, lahir di Magetan, 30 Maret 1966. Riwayat pendidikan: . S1 Sastra Daerah, Fakultas Sastra Universias Sebelas Maret, lulus 1993, S2. Prodi Pendidikan Bahasa Indonesia, Pascasarjana Universitas Negeri Semarang, lulus 2003, saat ini sedang menempuh S3. Prodi Pendidikan Bahasa Indonesia, Pascasarjana Universitas Negeri Semarang. Publikasi karya ilmiah: Makna Ritual dalam Risalah Tarekat Qadiriyah Naqsyabandiyah. Jurnal Analisa Vol.XVII,No.01, Januari-Juni 2010. Transformasi Nilai Keislaman Melalui Kitab Lokal (Kajian Teks Kitab Niyat Ingsun Ngaji Karya KH. Badawi Hanafi). 2010. Jurnal Analisa Vol.XVII,No.02, Juli-Desember 2010. Kerukunan Umat Beragama Masyarakat Transmigran di Kalimantan Tengah. 2010. Semarang: Akfimedia. Pesantren, Teks, dan Transmisi Islam dalam Modernisasi yang Dinamis dalam Kerangka Identitas Budaya di Pesantren. 2011. Jurnal INFERENSI STAIN Salatiga, Vol.5, No. 2 Desember 2011. Rukun Islam Satu, Kajian Kitab Tahyirah Mukhtasyar Karya 
KH. Ahmad Rifa'i. 2011. Semarang: Akfimedia. Nomor HP: 081326204330, Email: masarishidayat@yahoo.com

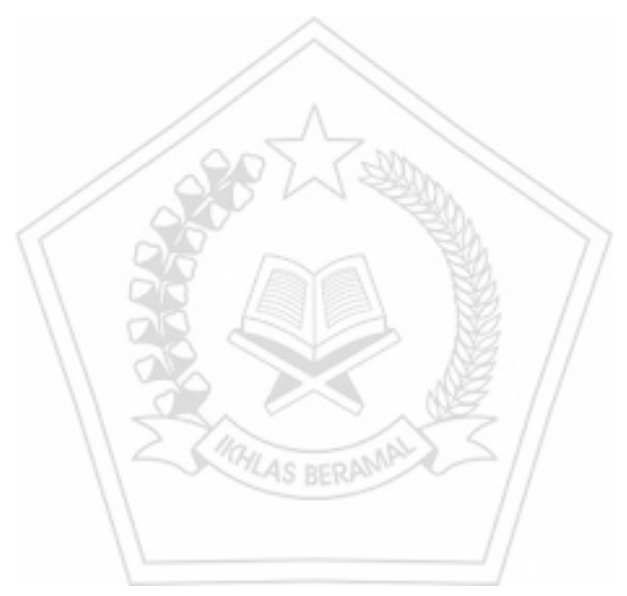




\section{Indeks}

\section{A}

Abidin, Mulyati dan Yunansah 6, 22, 30, 63, 64, 65, 66, 139 active learning 57

Ali dan Purwandi 72, 75, 76, 116, 137

Alvara Research Center 76

Amerika 8, 10, 40, 68, 69, 87, 114, 144, 168

applied sciences 45

Askov dan Fishbach 126

asset base community development 100

Australian National University (ANU) 116

B

Balai Litbang Agama Semarang 5, 15, 201, 204

Barton dan Hamilton 19, 127

bilingual university 48

budaya baca dan tulis mahasiswa 14

budaya copy-paste 141

budaya literasi 13,14

C

Central Connecticut State University (CCSU) 2, 8

Copy-Paste 37, 141

cultural studies 67

culture sharing 74

cyber space 5 


\section{D}

Deborah Brandt 10, 40

Dewayani dan Retnaningdyah 4, 9, 12, 13, 19, 20, 157

Direktorat Pendidikan Tinggi Keagamaan Islam (Diktis) 7

$\mathbf{E}$

era milenial 5, 39, 67, 162, 173

F

Faisal 68, 69, 70, 72, 73, 75, 125, 145, 146, 188

Fakultas Tarbiyah dan Keguruan UIN Sunan Gunung Djati Bandung 14 familiar with literature 15

fiksi bergenre realistik 134

filsafat (hadarat al-falsafah) 45

filsafat keilmuan 46

\section{G}

generasi mobile 75

generasi multiliterasi 67

generasi Y 69,73

genre fiksi 28, 37, 132, 133, 134, 137, 180

Genre fiksi 28, 134

genre non fiksi 28

Gustini, Rohaniawati dan Imani 4, 14

Guthrie dan Wigfield 26, 27

\section{H}

hermeneutika 67

Himpunan Mahasiswa Jurusan (HMJ) 33, 73, 184

Horizon ilmu (afaqul ilmi) 56

Hugo Hartig 138

\section{I}

Imam Suprayogo 47

indigeneous literacy 122

infrastruktur literasi 4, 6, 7, 32, 36, 79, 80, 175, 177 
Institut Agama Islam Negeri (IAIN) 41, 42

integrasi keilmuan 53, 59, 63, 66, 67, 119, 139, 175

\section{$\mathbf{J}$}

jurnal online 82,109

$\mathbf{K}$

kajian literasi 4, 7, 8, 9, 61, 67, 122

kajian literasi baru 7,8

Karl Mannheim 68

kemampuan literasi 2, 8, 19, 30, 31, 32, 67

Kementerian Agama 5, 6, 7, 15, 41, 44, 83, 173, 183, 184, 204

keterampilan literasi $16,65,114,177,183$

kitab suci 11

Kofi Annan 121, 122

Kompetensi Dasar Bahasa Indonesia 3

kompetensi literasi $1,2,7,20$

kualitas demokrasi 2

kualitas literasi 2, 3, 4, 32, 122, 144

Kuliah Qureta 117

$\mathbf{L}$

Lancaster University 10,198

layanan peminjaman koleksi 103

Lindsey Seitz 126

literasi $1,2,3,4,5,6,7,8,9,10,11,12,13,14,15,16,17,18,19,20$, $21,22,23,24,26,28,29,30,31,32,33,34,35,36,37,39,40$, $41,61,63,64,65,66,67,75,77,79,80,87,98,99,100,103$, $105,113,114,115,117,119,121,122,123,124,126,127,128$, $129,130,131,137,138,139,141,144,145,146,151,153,157$, $158,159,163,164,165,167,168,169,172,173,175,176,177$, $178,179,180,181,182,183,184,197,201$

literasi agama $11,17,63$

literasi anak $2,11,12,31$

literasi budaya 17, 65

literasi dasar 64

literasi disipliner 63

literasi ekonomi dan finansial 63 
literasi fungsional 20

literasi informasi $17,114,177,183$

literasi intrinsik 157

literasi lingkungan 17

literasi mahasiswa UIN 10, 33

literasi media 8,17

literasi media baru 17

literasi membaca $6,7,8,13,15,21,22,23,24,26,28,29,30,31,32$, $63,123,124,126,129,130,131,141,146,169,178$

literasi menulis $29,30,37,124,137,138,139,141,157,178,181$

Literasi menulis 29,30

literasi numerik $63,64,65$

literasi otonom 8,18

literasi politik dan kewarganegaraan 17

literasi teknologi komputer dan digital 17

literasi visual 17,153

literasi wanita buruh migran 12

local journal 82,84

\section{M}

ma'had 48

mahasiswa UIN 6, 10, 33, 77, 127, 139, 150, 154, 162, 168

M. Amin Abdullah 44, 45, 194

Manajemen Berbasis Sekolah 99

Massive Open Online Course (MOOC) 117

McConachie 63

media online $20,79,80,115,117,119,147,149,153,154,158,160$, 177

model integratif-interdisipliner 66

model menara kembar tersambung (integrated twin-towers) 53

motivasi ekstrinsik 26, 27, 113, 114, 130, 138, 144, 147, 177, 179, 181

motivasi intrinsik 26, 27, 113, 144, 157, 176, 182

multilerasi 6

multiliterasi $6,16,20,30,61,63,64,65,66,67,119,175$

multiliterate skills 63

multiple intelegence 14

$\mathbf{N}$ 
Nadirsyah Hosen 116

native digital 73

nilai-nilai keagamaan 11

non fiksi 28, 30, 37, 92, 132, 135, 136, 137, 170

$\mathbf{P}$

Pahdepie 132, 133, 192

Pardoe dan Ivanic 21

partisipasi politik 2

peer group 146, 173, 182

Peer group 75, 146

peer tutor 14

pelayanan perpustakaan 98,113

pembelajaran literasi 4, 30,138, 139

pembelajaran multiliterasi 64,65

pendekatan multimodal 20

Pendidikan untuk semua (education for all) 57

peradaban ilmu 44, 45, 46

peradaban teks (hadarat al-nas) 45

Perguruan Tinggi Agama Islam Negeri (PTAIN) 5, 41

Perguruan Tinggi Keagamaan Islam (PTKIN) 5

perilaku literasi 2, 29, 37, 124, 127, 128, 137, 141, 145, 178, 179

Perilaku literasi 137,178

Perilaku literasi mahasiswa 178

perilaku plagiat $143,144,145,181$

peristiwa literasi $19,34,79,87,99,103$

pohon ilmu 47, 48

pola praktik literasi $4,5,6,11,33,35$

praktik literasi $4,5,6,7,8,9,10,11,12,13,14,15,18,19,20,21,31$, $32,33,34,35,36,39,40,41,75,77,79,87,100,105,113,115$, $122,123,128,146,158,163,167,168,169,172,176,179,182$, 201

praktik literasi mahasiswa $5,6,11,13,33,34,35,36,39,77,79,87$, $100,115,123,158,163,172$

praktik literasi membaca dan menulis $6,13,15,21$

Preferensi 26, 27

prestasi literasi 4, 9

prestasi membaca 9 
pribumisasi Islam 60

problem generasi milenial 145,181

proses pembelajaran $114,128,183,184$

PTAI 7, 42

pure sciences 45

Q

Qureta 115, 117

$\mathbf{R}$

Rackley 9, 10, 11, 193

revolusi digital 5,75

$\mathbf{S}$

Sari dan Pujiono 13

self-terminating 27

situated literacies 127

sponsor literasi 10, 40

Statistik Jumlah Peminjaman Buku 106, 107

Strauss dan Howe 68, 69, 72, 73

Strickland dan Walker 126

struktur sosial 11

Susan D Blum 143

\section{$\mathbf{T}$}

Taylor, Peplau dan Sears 125, 126, 127

teaching learning 99

teori generasi 72,73

teori motivasi membaca 26

teori siklus generasi 68,73

the creator 70

The Cultivator Performer 70

the gold generation 69

The Progress in International Reading Literacy Study (PIRLS) 8

The Reading Connects 27

Thurtone 125

tingkat literasi siswa 8 
UIN Banjarmasin 44

UIN Mataram 44, 54, 55, 56, 57, 58, 61, 105, 106, 107, 108, 109, 112, $131,136,138,142,155,159,161,164,170,192,198,199,200$

UIN Maulana Malik Ibrahim Malang 46, 47, 48, 100, 104, 153, 192

UIN Sunan Ampel Surabaya 52, 53, 61, 91, 92, 93, 113, 152, 153, 192, 195

UIN Sunan Kalijaga Yogyakarta 44, 80, 81, 85, 113, 164, 167, 193, 199, 201

UIN Walisongo Semarang 49, 85, 86, 87, 88, 90, 113, 148, 150, 152, $166,192,199$

UIN Yogyakarta 53

Universitas Islam Negeri (UIN) 5, 39, 41, 46, 175, 183

University of Stirling 10, 198

\section{W}

wahdat al-'ulum (unity of sciences) 51

Website Qureta 117

well educated, learned 15

William Strauss dan Neill Howe 68

with wider mandate 43

World Economic Forum 1, 64, 65, 66, 196 


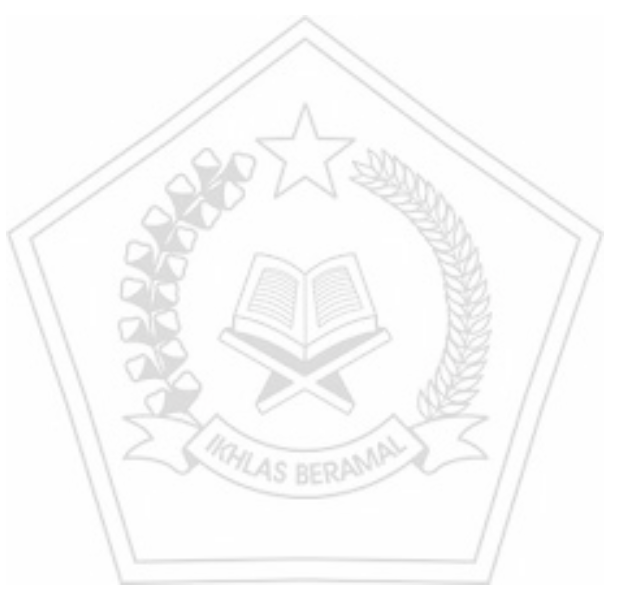

214 


\section{SUSUNAN ANGGOTA REVIEWER LITBANGDIKLAT PRESS}

1. Prof. H. Abd. Rachman Mas'ud, Ph.D.

2. Prof. Dr. H. M. Atho Mudzhar

3. Prof. Dr. Ridwan Lubis

4. Prof. Dr. Oman Fathurrahman

5. Prof. Dr. Imam Tolkhah

6. Prof. Dr. H. Moh. Isom, M.Ag.

7. Prof. Iik Arifin Mansurnoor, Ph.D.

8. Prof. Muhaimin AG.

9. Dr. Choirul Fuad Yusuf

10. Dr. M. Adlin Sila

11. Prof. (R). Dr. Qowaid

12. Dr. Kustini

13. Arif Zamhari, Ph.D.

14. Dr. Anik Farida

15. Dr. Fakhriati

16. Syaiful Arif, M.Hum.

17. Dr. H. Agus Ahmad Safei 


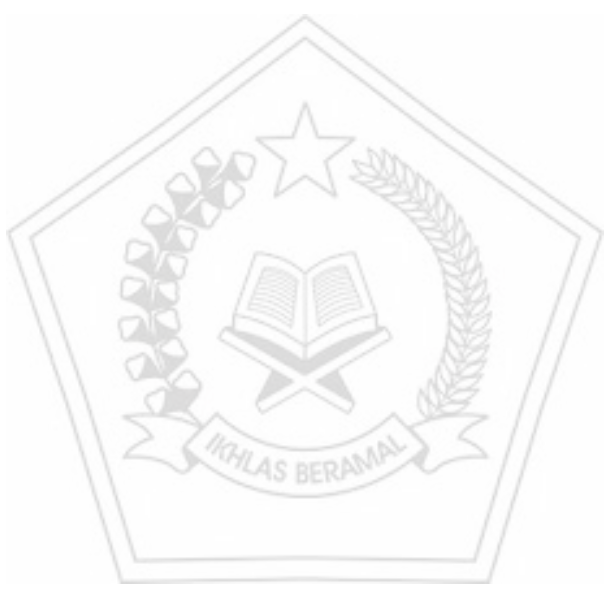

216 


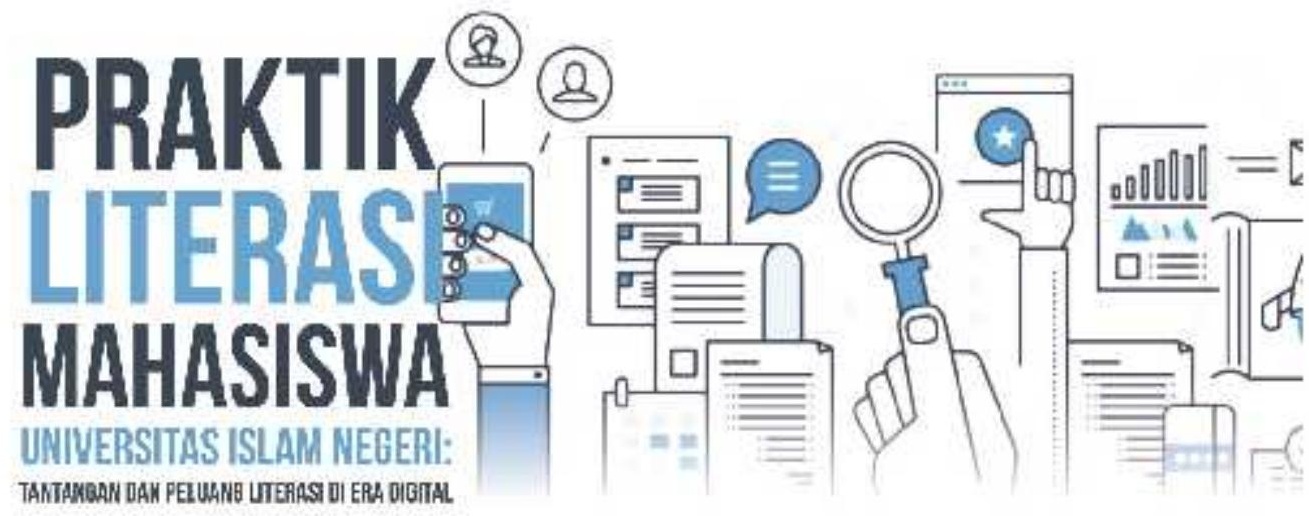

Tidak banyak ditemukan uraian mendalam tentang praktik literasi di lembagalembaga pendidikan berbasis agama, seperti Perguruan Tinggl Agama Islam Negeri \{PTAIVI. Pengetahuan tentang praktik dilembaga-lembaga pendidikan tinggi berbasis agama atau Perguruar Tinggi Keagamaan Islam (PTKIN) di Indonesia terbatirs, untuk tidakmengatakan kurang.

Pembahasan mendalam tentang praktik literasi di perguruan tinggi penting dilakukan, sebab perguruan tinggi dengan mahasiswa dan dosen d dalamnya adalah subyek yang memproduksi imu pengetahuan. Peran percuruan tingqi sebagai produsen ilmu pengetahuän menjadi ebih kompleks ketika dikaitkan dengan perkembangan cyber space atau teknologi digital seperti sekarang ini. Perguruan tinggi, termasuk perguruan tingg agama, dihadap an pada permasalahan literasi di tengah revolusi digital dewasa ni. Seperti apa praktik literasi mahasiswa di tengah abad literasi dan teknologi dig tal yane sedang dihacapi ini? Bagaimana infrastruktur yang mendukung praktik literasi di era milenial dan revolusi digital dalam teknologi informasi.

Buku ini berupaya menyajikan pola praktik literasi mehasiswa Universitas Islam Negeri (UIN) di Yogyakarta, Jawa Tengah (Semarang), Jawo Timur iSurabaya dan Malang). Nusa Tenggara Barat (Mataram), dan Kalimantan Selatan (Banjarmasin). Selain menggali pola praktik literasi dalam konteks perkembangan abad mi enia, buku ini juga mendiskusikan kondisi infrastruktur yang mendukung praktik literasi mahasiswa serta pemanfaatan infrastruktur tersebut untuk mengembangkan praktik literasi mahasiswa. Sebab kesediaan infrastruktur literasi dan akses a:au pemanfaatan infrastruktur literasi menjad salah satu faktor penting ber,alannya literasi.

Agus Iswanto | Moch. Lukluil Maknun | Mustolehudin Umi Masfiah | Subkhan Ridlo | Roch. Aris Hidayat

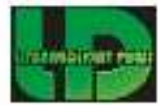

IXUn $4 \times U-b U t-31 \leq \mathrm{CL}-\Delta-1$

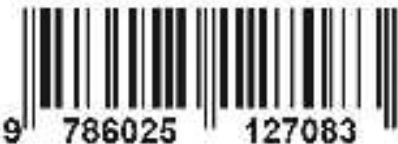

